2013-05-01

The Decision Usefulness Of Comprehensive Income Reporting In Canada

Deol, Harjinder

Deol, H. (2013). The Decision Usefulness Of Comprehensive Income Reporting In Canada (Unpublished doctoral thesis). University of Calgary, Calgary, AB. doi:10.11575/PRISM/28044 http://hdl.handle.net/11023/670

Downloaded from PRISM Repository, University of Calgary 


\section{UNIVERSITY OF CALGARY}

The Decision Usefulness Of

Comprehensive Income Reporting In Canada

by

Harjinder Deol

A THESIS

SUBMITTED TO THE FACULTY OF GRADUATE STUDIES

IN PARTIAL FULFILMENT OF THE REQUIREMENTS FOR THE

DEGREE OF DOCTOR OF PHILOSOPHY

HASKAYNE SCHOOL OF BUSINESS

CALGARY, ALBERTA

APRIL, 2013

(C) Harjinder Deol, 2013 


\begin{abstract}
In this study, I empirically investigate the decision usefulness of mandatory reporting of comprehensive income in Canada under the erstwhile Accounting Handbook Section 1530 (HB1530). Comprehensive income (CI) equals the sum of Net Income (NI) and Other Comprehensive Income (OCI). I operationalize the concept of decision usefulness in two ways: (i) value relevance, and (ii) association with analysts’ earnings forecasts.

As a theoretical framework, I draw upon Ohlson's (1999) discussion of the attributes of transitory earnings: forecasting irrelevance, unpredictability, and value irrelevance. Ohlson pointed out that the existence of any two attributes implies the third. That is, if an earnings item is irrelevant for forecasting future abnormal earnings, and if current numbers do not predict future ones (that is, if the earnings item is unpredictable), then it must be value irrelevant.

Drawing upon a sample of firms listed on the Toronto Stock Exchange, I employ a multivariate regression approach to test whether OCI and its individual components (namely, unrealized gains and losses on cash flow hedges - HEDGE, unrealized gains and losses on available for sale investments - SEC, and foreign currency translation adjustment on foreign subsidiaries - FOREX) possess forecasting relevance, predictability and value relevance. As a specification check, I also include a component of OCI under United States GAAP, minimum pension adjustment, PENADJ, to see if it possesses the same attributes as do components of OCI under HB1530. I also test for the association of OCI and its components with analysts' earnings forecasts.
\end{abstract}

I find that aggregate OCI and some of its individual components are relevant in forecasting future abnormal earnings, predictable, and incrementally value relevant. Aggregate OCI as well as some of its components are also able to predict future net income and operating cashflows. Aggregate OCI and some of its components are also significantly associated with analysts' earnings forecasts. Finally, some components of OCI are negatively significantly associated with analysts' forecast errors. These results suggest that Ohlson's (1999) description of transitory earnings might not apply to OCI, and that the reporting of comprehensive income in Canada did enhance the decision usefulness of accounting numbers. 
Additional analyses establish that the results are robust to differences observed for size, industry and macro economic variables such as interest rates, exchange rates and the rate of GDP growth. A significantly negative bias is observed for the period of adoption, but this could be attributed to the economic recession of 2007-2008. 


\section{Acknowledgements}

This dissertation is the culmination result of a long journey through which I benefited from the support of many remarkable individuals.

First, I would like to thank my supervisors, Dr. Irene Herremans and Dr. Hussein Warsame. Without Irene and Hussein's continuous and unflinching support, it is hard for me to conceive of how I could have completed my doctorate. Through good times and bad, they stood by me, unrelenting in their belief in my ability. I would also like to thank Dr. Norma Nielson from my supervisory committee. Norma's keen eye for detail, and her many suggestions helped me write a much better thesis than the first draft.

I would also like to extend profuse thanks to Dr. Kiridaran Kanagaretnam, whose work I have humbly sought to extend in this thesis. As my external examiner, Dr. Kanagaretnam was so encouraging and helpful that he made the dissertation defense one of the most memorable events as a doctoral candidate. Thanks also, to Dr. Frank Atkins, for suggesting several improvements that brought this thesis a long way forward.

I would also like to express my gratitude to all my professors, from whom I learned several invaluable lessons in my doctoral program. As a recipient of the Robert A Willson Scholarship, I cannot express how grateful I am for the financial support from donors to the Haskayne PhD Program. Thanks also to the PhD Program Directors I had the good fortune to work with - Dr. Tom Rohleder, Dr. Daphne Taras, Dr. Frances Bowen and Dr. Loren Falkenberg.

I have benefited from the support and encouragement from several colleagues at the Bissett School of Business, Mount Royal University. Special thanks to my chairs, Ilene Gilborn and Rik Smistad for their continued support. A huge thank you to Wendelin Fraser, past Dean at Bissett, and Dr. Murray Young, Dean, Bissett School of Business.

I have been blessed with love and support from my friends at the UofC - Clifford Spyker, Akinloye Akindoyami, Shujun Ding, Uthpala Tennakoon, Darlene Himick, Linda Ambrosie, Micheline Campanaro, Sylvia Fuchek, Louise McDonald and Lesley DiMarzo, at MRU Margaret Brown, Melanie Peacock, Paul Varella, Frank Cotae and Allan Dwyer and from my personal circle - Harprit Grewal, Junaid Malik and Gurvel Mangat. 
Finally, I would like to express my heartfelt gratitude to my friend, philosopher, guide AND a member of my committee - Jamal Nazari. Had it not been for Jamal, this dissertation might yet have never been completed. During countless sessions of coffee at Starbucks, Jamal continually kept me honest and focused on the singlemost important task - completing the dissertation.

Thank you! 
This dissertation is dedicated to my family who have supported me through the entire process.

\section{To my parents}

You've always believed in me. While times were never easy, you did your best to give me the gift of education. I have come thus far, with your blessings and love...

\section{To my lovely wife, Gurpinder}

You've stood by me through good times and bad. My dearest, dearest wife, this one's for you!

\section{To my children, Mayan and Robyn}

Papa loves you. More than he can ever say. I cannot ever make up for the hundreds of hours I stole from you. Someday you'll be able to understand. Papa needed to do this. For you. 


\section{Table of Contents}

Abstract

CHAPTER ONE: INTRODUCTION ......................................................................... 1

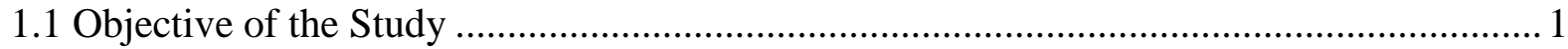

1.2 Data Collection and Overview of the Research Method ............................................... 2

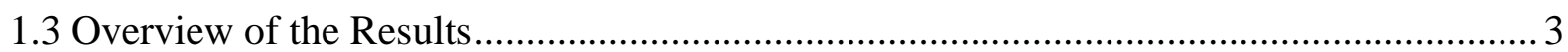

1.4 Overview of the Dissertation .............................................................................. 4

CHAPTER TWO: BACKGROUND AND MOTIVATION .................................................. 5

2.1 Adoption of Handbook Section 1530 Comprehensive Income in Canada ......................... 5

2.1.1 Controversial origins of comprehensive income ............................................. 6

2.1.2 Delayed adoption of comprehensive income in Canada ......................................... 8

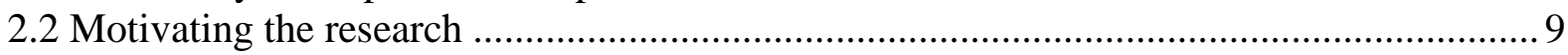

2.2.1 Consistency with international / U.S. standards ................................................ 9

2.2.2 Enhanced transparency of financial statements................................................. 12

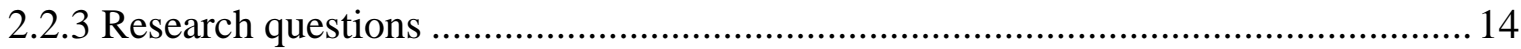

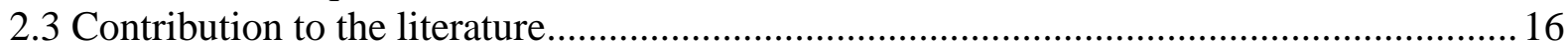

CHAPTER THREE: LITERATURE REVIEW ….................................................... 18

3.1 Studies examining whether other comprehensive income is transitory..........................2 24

3.2 Studies examining the value relevance of comprehensive income...............................26

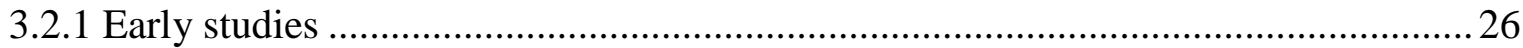

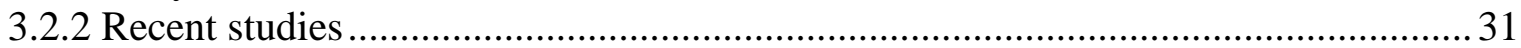

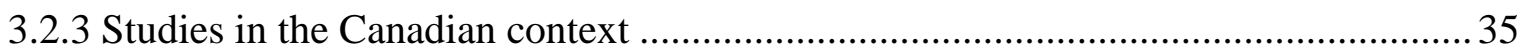

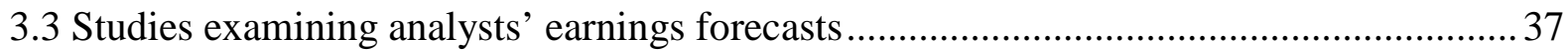

3.3.1 Importance of analysts' forecasts ...................................................................... 37

3.3.2 Information used by analysts in their earnings and valuation forecasts ....................38

3.3.3 Analyst forecast accuracy and potential reasons for forecast error ......................... 39

3.4 Implications of, and Conclusions from existing studies: the gap in the literature and

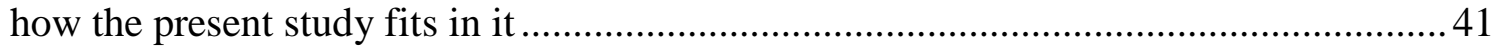

CHAPTER FOUR: THEORETICAL FRAMEWORK .......................................................... 44

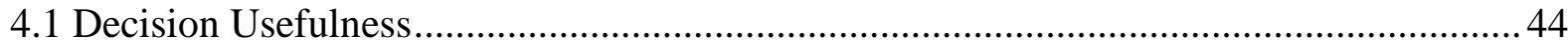

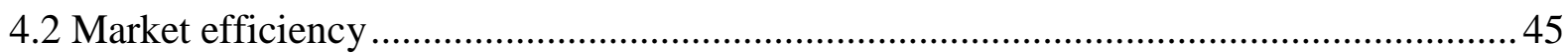

4.3 Ohlson's Residual Income Valuation model .......................................................... 46

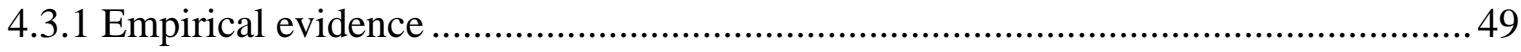

CHAPTER FIVE: RESEARCH DESIGN AND METHODOLOGY ....................................51 
5.1 Testing Ohlson's Residual Income Valuation model for transitory earnings................... 54

5.1.1 Regressions to test OCI's ability to forecast future abnormal earnings ....................56

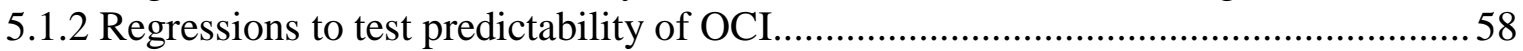

5.2 Testing for the value relevance of OCI and its components ........................................59

5.2.1 Valuation (Level) Regressions to test value-relevance of OCI and components ...... 60

5.2.2 Returns (Change) Regressions to test value-relevance of OCI and components ......63

5.3 Testing for association of OCI and its components with analysts' earnings forecasts ......64

5.3.1 Regressions to test association of OCI and components with analyst forecasts .......65

5.3.2 Regressions to test association of OCI and components with analyst forecast error 66

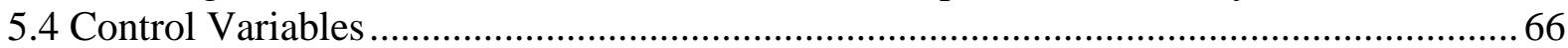

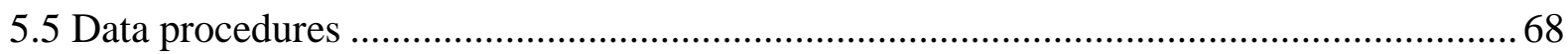

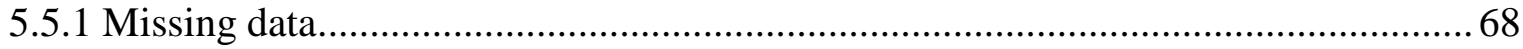

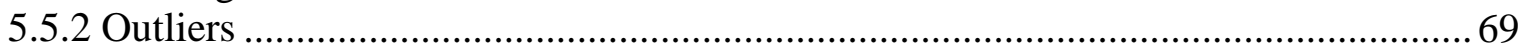

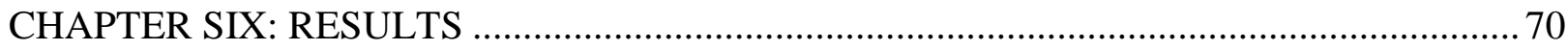

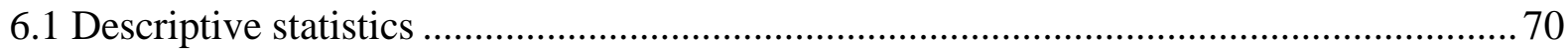

6.2 Results of regression analyses ............................................................................. 82

6.2.1 Regressions to test the ability of OCI and its components to forecast future

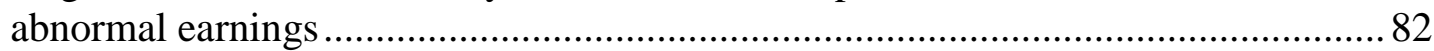

6.2.2 Regressions to test predictability of OCI........................................................ 84

6.2.3 Valuation (Level) Regressions to test value-relevance of OCI and components ......86

6.2.4 Returns (Change) Regressions to test value-relevance of OCI and components ......90

6.2 .592

6.2.6 Regressions to test association of OCI and components with analyst forecasts .......93

6.2.7 Regressions to test association of OCI and components with analyst forecast error 96

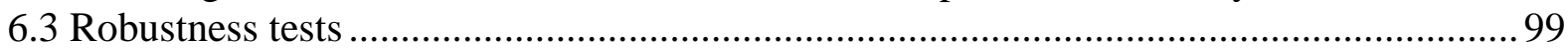

6.3.1 Controlling for size, leverage and industry ........................................................99

6.3.1.1 Regressions testing the ability of OCI and its components to forecast future

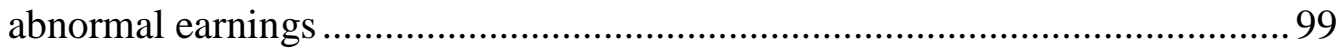

6.3.1.2 Regression to test predictability of OCI ................................................... 100

6.3.1.3 Valuation (Level) Regressions to test value-relevance of OCI and components ........................................................................................... 101

6.3.1.4 Returns (Change) Regressions to test value-relevance of OCI and

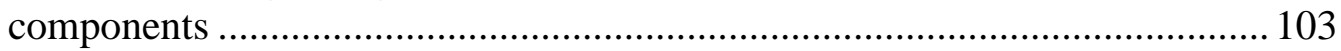

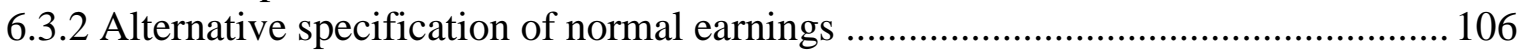

6.3.2.1 Regressions testing the ability of OCI and its components to forecast future

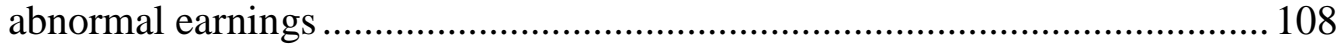

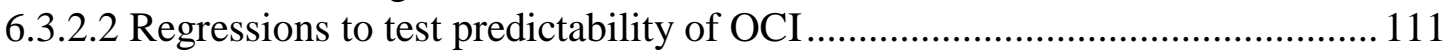

6.3.3 Testing the ability of OCI and components to predict future net income and operating cash flows .................................................................................. 113

CHAPTER SEVEN: DISCUSSION, LIMITATIONS AND FUTURE RESEARCH............. 117

7.1 Discussion of the contributions and limitations of this study ................................... 117

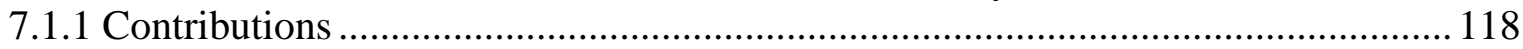

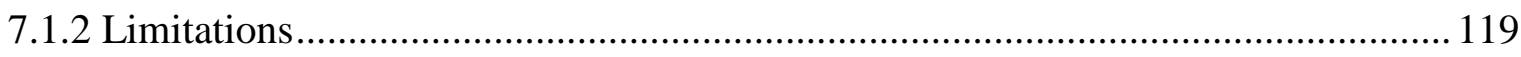

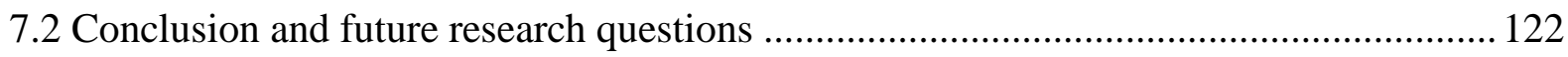




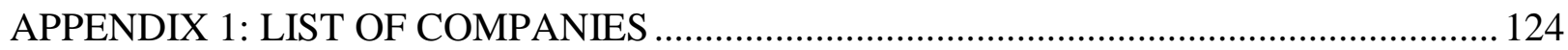

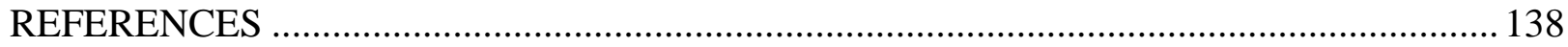




\section{List of Tables}

Table 3-1: Summary of literature review of selected studies examining some aspect of usefulness of comprehensive income, OCI or components ........................................... 18

Table 5-1: Illustrative example of a statement of comprehensive income .............................. 53

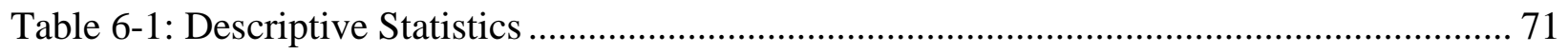

Table 6-2: Correlation matrices and Pearson coefficients .................................................... 75

Table 6-3: Regressions to test the ability of OCI and its components to forecast future

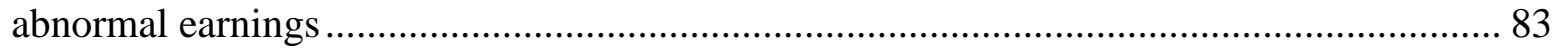

Table 6-4: Regressions to test predictability of OCI .......................................................... 85

Table 6-5: Valuation (Level) Regressions to test value-relevance of OCI and components........ 88

Table 6-6: Returns (Change) Regressions to test value-relevance of OCI and components ........ 92

Table 6-7 Regressions to test association of OCI and components with analysts’ forecasts ....... 95

Table 6-8 Regressions to test association of OCI and components with analyst forecast error ... 98

Table 6-9: Regression to test the ability of OCI and its components to forecast future

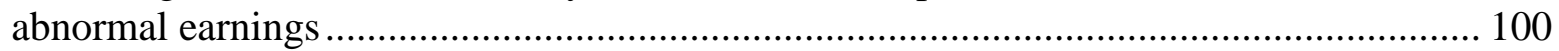

Table 6-10: Regressions to test predictability of OCI and components ............................... 101

Table 6-11: Valuation regression to test value relevance of OCI and components................... 102

Table 6-12: Returns (Change) Regressions to test value-relevance of OCI and components .... 104

Table 6-13 Summary of key macroeconomic data ........................................................... 106

Table 6-14: Annual Returns on the S\&P/TSX Index Portfolio and average industry level

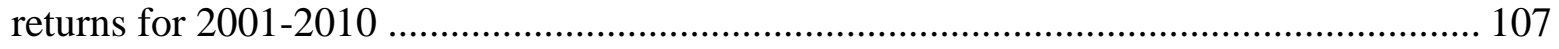

Table 6-15: Correlation matrix and Pearson Coefficients for various estimates of abnormal

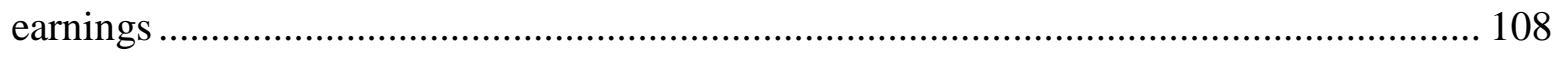

Table 6-16: Regression to test the ability of OCI and its components to forecast future

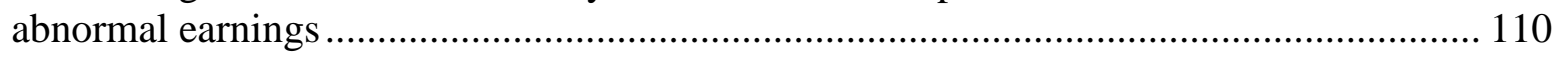

Table 6-17: Regressions to test predictability of OCI and components ............................... 113

Table 6-18: Regressions to test the ability of OCI and components to forecast future net income and operating cash flows 


\section{List of Figures and Illustrations}

Figure 1: Exchange rates for the Canadian Dollar against selected currencies ......................... 61

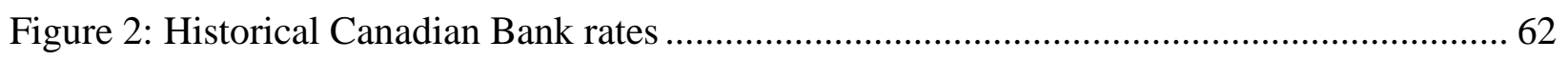

Figure 3: S\&P/TSX Index for the period January 1, 2005 - December 31, 2011 ................... 120

Figure 4: NYSE Composite (Dow Jones) Index for the period January 1, 2005 - December

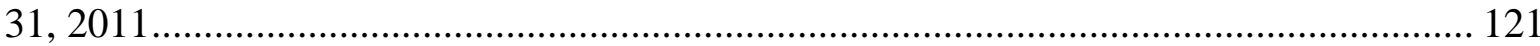




\section{Definitions of important terms and list of acronyms used in the study}

AbnEarn the difference between the actual earnings per share and the expected earnings specified as beginning book value per share multiplied by 12 per cent.

Accruals/S Per share amount of accruals, calculated as the difference between Operating Cash Flow per share and Net Income per share.

AEDiffOCI the difference between AbnEarn and $O_{15 I_{1530}}$.

AEInd $_{i t}$ the difference between the actual earnings per share and the expected earnings, specified as beginning book value per share multiplied by the average industry return for the calendar year.

$A E N I_{\text {it }}$ the difference between the actual earnings per share and the expected earnings, specified as the earnings per share of the previous fiscal year.

AETSX $_{i t}$ the difference between the actual earnings per share and the expected earnings, specified as beginning book value per share multiplied by the average $\mathrm{S} \& \mathrm{P} / \mathrm{TSX}$ portfolio return for the calendar year.

$B V E / S \quad$ the book value of common equity per share at the end of the fiscal year.

$D_{1} \quad$ Dummy variable coded 1 if the net income for the year was negative.

$D_{2} \quad$ Dummy variable coded 1 if the year was 2006 and after.

EPS Earnings Per Share for firm $i$ for immediately preceding fiscal year.

FERR Forecast error in mean consensus analysts' earnings forecast, calculated as (Actual EPS - IBESMean)/Price ${ }_{\text {it-1 }}$.

FOREX change in cumulative foreign currency translation adjustment under Canadian GAAP for the fiscal year.

HEDGE the change in the fair value of cash flow hedges under Canadian the fiscal year. IBESMean Mean analysts' forecast estimate from I/B/E/S of Earnings per share (EPS) for firm $i$ immediately preceding earnings announcement. 
IBESMed Median analysts' forecast estimate from I/B/E/S of EPS for firm $i$ immediately preceding earnings announcement.

LnMVE Natural log of market value of equity for firm $i$ at the beginning of fiscal year (a proxy for size).

LnTV Natural log of average trading volume for firm $i$ stock (another proxy for size).

$\mathrm{LnFol}_{\text {it }} \quad$ Natural log of the number of analysts providing earnings forecasts for firm $i$ shares (another proxy for size).

MNMD Difference between the mean and median consensus analyst earnings forecasts, calculated as (IBESMean - IBESMed)/ Price $_{\text {it-1 }}$.

NI/S net income per share after extraordinary items and discontinued operations for the fiscal year.

$O C F / S_{i t} \quad$ operating cash flow per share for the fiscal year t;

$O_{1530}$ the sum of HEDGE (fair value changes in cash flow hedges), SEC (fair value changes in available for sale investments) and FOREX (changes in cumulative foreign currency translation adjustment) following Canadian GAAP.

$O C I_{130} \quad O C I_{1530}$ plus $P E N A D J$ (pension adjustment on defined benefit pension plans, as required under SFAS 130 of U.S. GAAP.

P/S $\quad$ per share price three months after the end of fiscal year.

PENADJ the per share change in additional minimum pension liability in excess of unrecognized prior service costs under SFAS 130 for the fiscal year.

RET stock returns (change in stock price plus dividends declared) for the year ended three months after the end of fiscal year.

SEC the change in the fair value of available-for-sale investments under Canadian GAAP for the fiscal year. 


\section{Illustrative example of a statement of comprehensive income}

\section{Statement of Comprehensive Income}

For the year ended December 31 (\$ thousands)

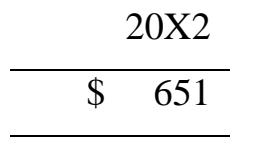

Other comprehensive income, net of tax
Unrealized gains and losses on translating financial statements of self-sustaining foreign operations (a)

Gains and losses on hedges of unrealized foreign currency translation losses and gains

Unrealized foreign currency translation gains and losses, net of hedging activities

Unrealized gains and losses on available-for-sale financial assets arising during the period

Reclassification adjustment for gains and losses included in net income

Change in unrealized gains and losses on available-for-sale financial assets

Gains and losses on derivatives designated as cash flow hedges

Gains and losses on derivatives designated as cash flow hedges in prior periods transferred to net income in the current period

Change in gains and losses on derivatives designated as cash flow hedges

Other comprehensive income

Comprehensive income
547

627

2

1,689

277

62

\begin{tabular}{r}
1,372 \\
\hline 1,723 \\
$(995)$
\end{tabular}

339

687

(333)

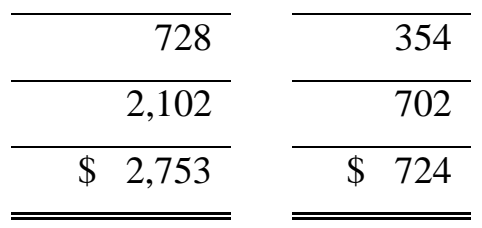

(a) It is assumed that there was no reduction in the net investment in a foreign operation. Therefore, there is no reclassification adjustment.

source: Reproduced from CICA Accounting Handbook section 1530 Comprehensive Income, paragraph 12. 


\section{Chapter One: Introduction}

\subsection{Objective of the Study}

In 2005, the Canadian Accounting Standards Board (the AcSB) issued Handbook ${ }^{1}$ Section (HB) 1530, Comprehensive Income. Comprehensive income (CI) was defined as "the change in equity (net assets) of an enterprise during a period from transactions and other events and circumstances from non-owner sources” (CICA HB1530, para 3a). Comprehensive income comprised Net Income (NI), and Other Comprehensive Income (OCI). OCI as defined under HB1530 (hereafter referred to as $\mathrm{OCI}_{1530}$ ) included three components, namely, (1) unrealized gains and losses on available-for-sale financial assets, (2) unrealized gains and losses on foreign currency translations, and (3) gains and losses on derivatives designated as cash flow hedges.

The provisions of HB1530 were broadly similar to those of Statement of Financial Accounting Standard (SFAS) 130 under the United States’ Generally Accepted Accounting Principles (US-GAAP), except that OCI under SFAS 130 (hereafter referred to as OCI $_{130}$ ) included an additional item - minimum pension adjustment. Historically, Canadian GAAP had been strongly influenced by US GAAP and the Canadian Accounting Standards Board was working on harmonizing Canadian GAAP with US GAAP (Blanchette and Desfleurs 2011). It is therefore somewhat surprising that HB1530 was adopted in Canada almost eight years after its counterpart in the United States, SFAS 130. It is even more surprising that section 1530 was adopted at a time when the AcSB had decided to adopt International Financial Reporting Standards as GAAP for publicly accountable entities (Accounting Standards Board of Canada 2006).

There was considerable debate within the academic and practitioner communities in the United States whether SFAS 130 would provide useful information (Norton and Porter 1982;

\footnotetext{
${ }^{1}$ Canada has since adopted IFRS for publicly accountable entities, and the Accounting Handbook now consists of five parts:

Part I: International Financial Reporting Standards (IFRS), Part II: Accounting Standards for Private Enterprises (ASPE), Part III: Accounting standards for Not-for-Profit Organizations, Part IV: Accounting standards for Pension Plans, and Part V: Canadian GAAP applicable till December 31, 2010. Throughout this dissertation, section 1530 refers to the section from the erstwhile GAAP (now Part V of the Handbook)
} 
Robinson 1991; Knutson and AIMR 1993; Bisgay 1995; Beresford et al. 1996; Cope et al. 1996; Foster and Hall 1996; Johnson and Swieringa 1996; Smith and Reither 1996; Brauchle and Reither 1997; Linsmeier et al. 1997a). Ohlson (1999) captured the essence of the argument that the items included in OCI were transitory, and therefore, could not be expected to be value relevant. Empirical studies of the value relevance of Comprehensive Income conducted during the late 1990s and early 2000s provided mixed evidence on the superiority of comprehensive income related to other performance measures (Cheng et al. 1993; Hirst and Hopkins 1998; Dee 1999; Dhaliwal et al. 1999; Maines and McDaniel 2000; Cahan et al. 2000; Louis 2001; Brimble and Hodgson 2004). However, later studies did find some evidence to support the value relevance of OCI (Biddle and Choi 2006; Choi and Zang 2006; Chambers et al. 2007; Choi et al. 2007; Kanagaretnam et al. 2009).

The objective of this study is to investigate empirically, using actually reported accounting data by Canadian firms, whether mandatory reporting in Canada of $\mathrm{OCI}_{1530}$ and its components under HB1530, had decision usefulness incremental to, net income. I examine decision usefulness in two ways: (i) value relevance of items of OCI incremental to net income, and (ii) relationship between OCI numbers and analysts’ earnings forecasts.

\subsection{Data Collection and Overview of the Research Method}

This study uses data on variables of interest from the following databases - Compustat (accounting data), CRSP (stock price information) and I/B/E/S (analyst forecasts) - accessed from Wharton Research Data Services. The sample for the study is drawn from an initial pool of 3,969 firm-year observations for 535 companies which have been constituents of the S\&P/TSX Composite Index for at least one year for the financial years 2001 through 2010. However, missing data and controls for outliers resulted in a reduction in the usable observations to between 675 and 1464 firm-year observations for 411 companies.

To be consistent with recent value-relevance studies examining OCI, I use Ohlson's (1999) discussion of transitory earnings. Ohlson (1999) extends the work of Ohlson (1995) and Feltham and Ohlson's $(1995,1996)$ on the residual income model. Also known as clean surplus theory, the residual income model specifies market value as a function of book value of equity and 
present value of future abnormal earnings. Ohlson’s (1995) Clean Surplus Relation ${ }^{2}$ is a useful starting point to examine the value relevance of Comprehensive Income, which is a performance measure broader in its scope than is Net Income, and thus provides information on earned income as well as unrealized gains and losses which could potentially affect firm value. However, Ohlson's (1999) discussion of transitory earnings (described in Chapter 4), along with the assumption held by several studies that all items of OCI are transitory in nature, do not support a hypothesis predicting value relevance for OCI.

In this study, I examine whether items of OCI really meet Ohlson's (1999) described properties of transitory earnings: unpredictability, forecasting irrelevance and value-irrelevance. Ohlson (1999) suggested that the existence of two properties would imply the third. I test the OCI numbers for unpredictability and forecasting irrelevance. My reasoning is that if OCI demonstrates predictability and forecasting relevance, then they should also be value relevant.

\subsection{Overview of the Results}

Consistent with Jones and Smith (2011), who find that OCI items exhibit negative persistence, I find that OCI and its components are predictable, with lagged values being significantly negatively associated with current values.

I also find that OCI and some of its components are relevant for forecasting future abnormal earnings. In additional analyses, I also find that OCI and some of its components are relevant for predicting future net income and future operating cash flows.

Controlling for book value of equity and net income, I find that some components of OCI are significantly correlated with stock price. Similarly, controlling for market returns and net income, elements of OCI are significantly correlated with stock returns. These conclusions support the findings of recent studies examining the value relevance of OCI (Chambers et al. 2007; Kanagaretnam et al. 2009; Jones and Smith 2011).

\footnotetext{
${ }^{2}$ According to the Clean Surplus Relation (CSR), all changes in book values $b v_{t}$ are reported as either income $x_{t}$ (for the period) or dividends $d_{t}$ (assumed to be paid at the end of the period, thus reducing the book value of the assets retained by the firm). Thus:

$$
b v_{t}=b v_{t-1}+x_{t}-d_{t} \ldots(C S R)
$$


I also find that some items of OCI are significantly correlated with analysts’ forecasts of earnings per share. Finally, I find that two components of OCI are significantly negatively correlated with analysts' forecast errors. These findings imply the OCI information that analysts use in their forecasting models, contribute towards greater forecast accuracy.

This study extends the discussion of the decision usefulness of comprehensive income reporting, using as-reported numbers from Canada. Its primary contribution to the literature is its empirical examination of the assumption that OCI items are transitory. It concludes that OCI and its components exhibit some degree of negative persistence. In addition, it provides further evidence of the value relevance of OCI information, and supports the current presentation model which splits comprehensive income into net income and OCI.

\subsection{Overview of the Dissertation}

The current chapter introduced the objectives of the study, the research approach and an overview of the key results. Chapter Two provides background information on HB Section 1530, Comprehensive Income, and its adoption in Canada. It also provides a discussion of the motivation for the current study. Chapter Three reviews the existing literature relevant to the study. I discuss the implications of the conclusions from existing studies and identify gaps in the literature, some of which this study seeks to address. Chapter Four describes the theoretical framework which guides this study. It provides a brief discussion of the concept of decision usefulness as used in this study, as well as brief overview of Ohlson's residual income valuation model and my underlying assumption about market efficiency in using stock price information. Chapter Five describes the research design and methodology employed for this study. It formally introduces variables of interest, data sources and procedures, as well as the regression models used. Chapter Six reports the results of this study. Chapter Seven concludes this dissertation with a discussion of the results in relation to the existing literature, acknowledges limitations in this study and describes some possible questions for future research in this area. 


\section{Chapter Two: Background and Motivation}

\subsection{Adoption of Handbook Section 1530 Comprehensive Income in Canada}

In 2005 the Canadian Accounting Standards Board (the AcSB) issued Handbook ${ }^{3}$ Section (HB) 1530, Comprehensive Income. Comprehensive income (CI) was defined as "the change in equity (net assets) of an enterprise during a period from transactions and other events and circumstances from non-owner sources" (CICA HB1530, para 3a). It consisted of Net Income (NI), and Other Comprehensive Income (OCI), items including (1) unrealized gains and losses on available-for-sale financial assets (SEC), (2) unrealized gains and losses on foreign currency translations (FOREX), and (3) gains and losses on derivatives designated as cash flow hedges (HEDGE).

The Canadian Standard was based on the US Financial Accounting Standard Board's (the FASB) Statement of Financial Accounting Standard 130 (SFAS 130), which defines comprehensive income in exactly the same manner as Canadian Handbook Section 1530, except that SFAS 130 includes an additional item under OCI - minimum pension adjustments (PENADJ) ${ }^{4}$. SFAS 130 allows for three options for reporting OCI: (a) in an income statement as a continuation of net income; (b) in a separate statement beginning with net income; and (c) in the statement of changes in equity. HB1530 too provided for these three reporting options. The application of hedge accounting was also optional, with Canadian firms allowed to comply with SFAS 133 and with International Accounting Standard (IAS) 39. The AcSB also issued HB 3855, Financial Instruments - Recognition and Measurement; and HB 3865, Hedges, which were also similar to the FASB's SFAS 115 and 133 respectively.

\footnotetext{
${ }^{3}$ Canada has since adopted IFRS for publicly accountable entities, and the Accounting Handbook now consists of five parts:

Part I: International Financial Reporting Standards (IFRS), Part II: Accounting Standards for Private Enterprises (ASPE), Part III: Accounting standards for Not-for-Profit Organizations, Part IV: Accounting standards for Pension Plans, and Part V: Canadian GAAP applicable till December 31, 2010. Throughout this dissertation, section 1530 refers to the section from the erstwhile GAAP (now Part V of the Handbook)

${ }^{4}$ Under IFRS, an additional item, revaluation gains under the revaluation model, is included in OCI.
} 


\subsubsection{Controversial origins of comprehensive income}

The adoption of SFAS 130 in the United States was the result of lengthy deliberation and a split vote (Biddle and Choi 2006) The origins of the debate date back to the early 1900s, in the works of the likes of Dicksee (1982), Dickinson (1987), Paton (CICA 2005b; Freeman and Tse 1992), Preinreich (1936), Littleton (Fama and French 1992; Littleton 1940) and others on the concept of Clean Surplus (Brief and Peasnell 1996). Ohlson (1995) and Feltham and Ohlson $(1995,1996)$ extended the discussion by providing a theoretical framework for how the clean surplus relation could be used in security valuation. Clean surplus accounting requires that earnings, adjusted for dividends, should articulate beginning-of-period retained earnings to endof-period retained earnings. That is, Ending Retained Earnings equals Beginning Retained Earnings plus Earnings minus Dividends. This is possible when all transactions are recorded in the earnings statement.

Items that bypass reported earnings but are adjusted against retained earnings in the balance sheet are called dirty surplus items. The basic premise of the clean surplus relation is that all changes in shareholders' equity that do not arise from transactions with shareholders (e.g. dividend payments, capital contributions) should be reflected in an income statement. Dirty surplus is said to arise when some non-shareholder-related items are adjusted directly to shareholders' equity, thus bypassing the income statement. In other words, dirty surplus is a component of comprehensive income which is excluded from reported earnings and, therefore, violates the clean surplus relation (Landsman et al, 2011). Traditionally, the accounting definition of income typically excluded unrealized gains and losses, and tended to favour historical costs (reliability) over market/fair values (relevance).

\section{In Statement of Financial Concepts $3^{5}$, Elements of Financial Accounting Statements of} Business Enterprises, the FASB defined comprehensive income as the change in a business entity's net assets for a period from all sources except transactions with owners. This definition

\footnotetext{
${ }^{5}$ SFAC 3 was later replaced by SFAC 6 in 1985, which extended the definitions from SFAC 3 to not-for-profit organizations (Johnson et al 1995, p129)
} 
was similar to the "all-inclusive" income that satisfied the clean surplus relation. In the early 1990s, calls for reporting comprehensive income began emerging (Johnson et al. 1995; Robinson 1991).

In 1993, the Association for Investment Management and Research (AIMR) ${ }^{6}$ urged for the practical implementation of comprehensive income in a position paper entitled Financial Reporting in the 1990s and Beyond (Knutson and AIMR 1993) ${ }^{7}$. The position paper purported to present the views of financial analysts, and argued that the field of financial analysis was faced with challenges and opportunities presented by the rapid globalization of capital markets, improved and cheaper computing power and the enhanced role of financial assets in the economic activity of firms. The document recommended reporting of market values for financial instruments and called upon the FASB to develop its concept of comprehensive income. It noted:

It is axiomatic that it is better to know what something is worth now than what it was worth at some moment in the past ... Historic cost itself is in reality historic market value, the amount of a past transaction engaged in by the firm. . . Historic cost data are never comparable on a firm-to-firm basis because the costs were incurred at different dates by different firms (or even within a single firm). There is no financial analyst who would not want to know the market value of individual assets and liabilities [AIMR, 1993, p39 cited in Centre for Financial Market Integrity (2007)].

In response to such calls, the FASB initiated a project on reporting comprehensive income. The project attracted much attention from academics and practitioners (Foster and Hall 1996; Linsmeier et al. 1997a, 1997b; Beresford et al. 1996; Brauchle and Reither 1997; Cope et al. 1996; Randall and David 1998). Studies examining the extent of reporting comprehensive income, and articles elucidating the requirements of the standard, were published both before and shortly after the adoption of SFAS 130 (Rao and Walsh 1999; Godwin and Alderman 1999; Keating 1999; Johnson and Swieringa 1996).

\footnotetext{
${ }^{6}$ The AIMR is now known as the Certified Financial Analysts (CFA) Institute

${ }^{7}$ Interestingly, although this document is widely cited, no online copy appears to exist. A summary was published by AIMR in 1992 (Financial Accounting Policy Committee 1992)
} 
Early empirical studies did not have readily available values for OCI, and so the researchers calculated the amounts (called as-if values). Based on these as-if values, these earlier studies found that comprehensive income was not incrementally useful over other well-established metrics for income such as operating income and net income (Cheng et al. 1993; Dhaliwal et al. 1999). Experimental studies on whether sophisticated users of accounting information, such as analysts, were able to detect earnings management through the use of comprehensive income (Hirst and Hopkins 1998) and whether non-professional users were affected by the manner in which comprehensive income was reported (Maines and McDaniel 2000) also came to less-thanfavourable conclusions about the general usefulness of comprehensive income.

\subsubsection{Delayed adoption of comprehensive income in Canada}

Until the early twenty-first century, Canadian GAAP had been strongly influenced by US GAAP and the Canadian Accounting Standards Board was working on harmonizing Canadian GAAP with US GAAP (Blanchette and Desfleurs 2011; Accounting Standards Board of Canada 2004). It was, therefore, somewhat surprising that CICA HB1530 was adopted almost eight years after its counterpart in the United States, SFAS 130. It was even more surprising that section 1530 was adopted at a time when the AcSB had decided to adopt IFRS (Accounting Standards Board of Canada 2006). HB1530 became effective for firms with financial years beginning October 2006 and later, with firms qualifying for differential reporting getting an extra year to implement the standard ${ }^{8}$. Under differential reporting, companies had the option of choosing among alternatives for how they accounted for subsidiaries, long term investments, joint ventures, share capital, income taxes and for financial instruments (Miller 2002). In terms of reporting comprehensive income, the only differential reporting option was that under section 3855 - an ability to elect to account for certain available-for-sale assets at cost- or amortizedcost, instead of fair value (PriceWaterhouseCoopers 2005).

${ }^{8}$ According to paragraph 1300:06 of the CICA Handbook, "an enterprise [was] a qualifying enterprise for purposes of the differential reporting options set out in an Accounting Standard, Accounting Guideline or Abstract of Issue discussed by the Emerging Issues Committee when and only when: (a) it [was] a non-publicly accountable enterprise; and (b) its owners unanimously consent[ed] to the application of differential reporting options in accordance with paragraph 1300.13.” 
The delay in adopting HB1530 in Canada could partly have been due to the fact that Canadian GAAP required gains and losses to be included in the income statement, thus already adhering to the requirement of clean surplus accounting. The AcSB had initially been of the view that changes in fair value of financial instruments should not be excluded from net income, something that the concept of Other Comprehensive Income permitted (CICA 2005, para 6-8). Before the issue of Section 1530, Canadian GAAP did not require, or permit, most gains or losses to be excluded from net income, and had held the view that "there is little conceptual basis for excluding gains and losses on changes in fair value of financial instruments from net income... [since] such losses and gains [neither] meet the definition of assets or liabilities... [nor] do they meet the definition of equity” (CICA 2005, para 6-8). In other words, the AcSB was not initially supportive of the use of OCI. This begs the question: why did the AcSB decide to adopt section 1530 ?

\subsection{Motivating the research}

In its discussion of the basis for conclusions, the AcSB provided two reasons for the introduction of section 1530: (i) harmonization with international / U.S. standards, and (ii) enhanced transparency of financial statements. It hoped that "the use of comprehensive income ... will not result in a significant cost to prepare and will help make certain gains and losses more transparent to financial statement users". ${ }^{9}$

\subsubsection{Consistency with international / U.S. standards}

Supporters of harmonization of standards claimed that it would help Canadian companies reduce reporting costs. As standards converged across jurisdictions, the need for having to prepare reconciliation statements from one GAAP to another would be minimized. Moreover, it was argued that users would find it easier to compare financial statements for companies across countries. Later on, studies would help buttress this argument in favour of harmonization. For example, Bae, Tan and Welker (2008) found that GAAP differences are negatively correlated

\footnotetext{
${ }^{9}$ Curiously, when the AcSB developed its separate set of accounting standards for private enterprises (Part II of the current Accounting Handbook), it chose not to retain other comprehensive income as an element of financial statements.
} 
with foreign analyst following, and with forecast accuracy. In a related study, Tan, Wang and Welker (2011) found that mandatory IFRS adoption attracts foreign analysts, especially from other IFRS-adopting countries, and that to the extent that the adoption of IFRS reduces GAAP differences, it also improves foreign analysts’ forecast accuracy. Daske et al (2008) found that mandatory IFRS reporting leads to increased market liquidity, increased equity valuations, and a decrease in firms' cost of capital in countries where firms have incentives to be transparent and where legal enforcement is strong.

A more skeptical view could be that international harmonization provides fewer economic benefits than are claimed by its proponents, and that the move towards harmonization might have political and social motivations (Chua and Taylor 2008) intended to help promote globalization of "big-four" accounting services (Arnold 2005). It has also been alleged that the standard setting process of international accounting standards may be susceptible to influence from powerful industry players as was the case for IFRS 6 which dealt with accounting for extractive industries ${ }^{10}$ (Cortese and Irvine 2010).

In its discussion of the basis for conclusions, the AcSB noted that both the FASB and the IASB had adopted an approach that required a firm to recognize certain gains and losses in a separate statement as "other comprehensive income" or "equity". The IASB and the FASB had formed a joint advisory group for this project. Since Canada was committed to adopting International Financial Reporting Standards (IFRS) by January 2011, it was logical that Canada should adopt a standard consistent with IFRS. The AcSB claimed that "without introducing other comprehensive income”, it would not have been possible to "introduce comprehensive standards for accounting for financial instruments in Canada that are converged with those in place internationally” (CICA 2005a).

At the time HB1530 was introduced, the AcSB recognized that future conclusions of the joint IASB/FASB/ UK Accounting Standards Board project on Financial Performance Reporting were

\footnotetext{
${ }^{10}$ There was intensive lobbying against the IASB's initial decision to make the successful efforts method mandatory under IFRS 6 Exploration for and Evaluation of Mineral Resources. These efforts resulted in the retention of choice between successful efforts and full cost accounting for pre-production costs.
} 
uncertain and that international consensus on the standard was not expected in the near term. Meanwhile, the US remained the major international trading partner for Canada. The United States accounted for approximately 75 (51) percent of all Canadian exports (imports) as of the year 2009 (CIA 2008). Also, as of 2003 more than 180 Canadian firms were cross-listed on the New York Stock Exchange (NYSE), the American Stock Exchange, or the NASDAQ (Gray 2005; Hendry and King 2004). Approximately 15 percent of Toronto Stock Exchange (TSX) listed firms also had a U.S. listing, making Canadian firms the single largest group of foreign firms listed on U.S. stock exchanges. Although the Canada-U.S. Multi-jurisdictional Disclosure System allows eligible Canadian public companies to access the U.S. public markets using Canadian disclosure documents and without becoming subject to the U.S. domestic registration and reporting system (Gray 2005), it could be argued that it was preferable to financial statement preparers if the standards in both jurisdictions were as similar as possible.

For example, a 1997 interim submission by the Canadian Bankers’ Association to the Task Force on the Future of the Canadian Financial Services Sector read as follows:

“Our primary concern is that, as the U.S. is Canada's most significant trading partner and both countries have similar markets and economic environments, it is of utmost importance that we continue to be closely aligned with the U.S. on major accounting developments (particularly as four of Canada's banks already or shortly must file U.S. GAAP financial statements to support SEC registration). While global harmonization in principle is desirable, for practical reasons, the CICA's focus must be on promoting harmonization of measurement and valuation accounting standards for financial instruments with the U.S.. Moreover, the banks feel that Canada is not in the best position to lead the world in this regard due to our relative size on the international scale and the competitive disadvantage that will result in comparisons with our U.S. counterparts” (emphasis added, (Canadian Bankers Association 1997), p4)

SFAS 130 allowed companies following U.S. generally accepted accounting principles (USGAAP) to bypass the income statement and report certain (unrealized) gains and losses as part of OCI, whereas prior to the introduction of Section 1530, companies following Canadian GAAP were required to include them in the income statement. This was regarded as a possible disadvantage for Canadian GAAP companies, as noted by the AcSB: “[I]t is unlikely to be 
acceptable to introduce a requirement for Canadian enterprises to recognize all gains and losses in net income when foreign competitors have the ability to do otherwise" (CICA 2005; para 12).

At face value, the generally inconclusive findings in the literature for comprehensive income and its components may well lend credence to a political pressures argument. For instance, although the AcSB felt that "the use of comprehensive income is not an elegant option... [it] concluded that it is a necessary and worthwhile first step to introduce an ability for Canadian enterprises to exclude certain (strictly controlled) gains and losses from net income" (CICA 2005, para 12). This line of reasoning resonates with a political pressures or 'economic consequences' view of accounting standard setting (Zeff 2002, 1997), which views such political pressures to mean "self-interested considerations or pleadings by preparers and others that may be detrimental to the interests of investors and other users” (Zeff 2002)

\subsubsection{Enhanced transparency of financial statements}

The desire expressed by the AcSB for greater transparency of the "certain gains and losses" may be interpreted as suggesting that disclosing them as part of OCI would result in an increased value relevance of accounting information. A counter-argument would suggest that having to report items in its income statement which competitors elsewhere (primarily the U.S.) could disclose as OCI, thus bypassing the income statement, placed Canadian companies at a potentially disadvantageous position in the market for capital. It should be noted here that this perspective does not subscribe to market efficiency, and appears to believe that the manner and place in which information is presented is important and determinative of the reactions by financial statement users. Recall that similar to SFAS 130, HB1530 provided for three possible reporting formats:

1. in the income statement below the total for net income;

2. in a separate statement of comprehensive income that begins with net income; or

3. in a statement of changes in equity, provided that statement is displayed as a primary financial statement and not in the notes (CICA 2005b) 
Standard setters had hoped that reporting comprehensive income in either a second statement of income or an expanded income statement would lead to enhanced understandability of financial statements (Beresford et al. 1996). However, following the introduction of SFAS130, most companies in the US chose to disclose comprehensive income items as part of the statement of changes in shareholders’ equity (Bhamornsiri and Wiggins 2001; Pandit and Phillips 2004; Pandit et al. 2006), instead of reporting it in a performance statement such as the statement of comprehensive income. Why should reporting choice matter? If market efficiency holds, the choice of how comprehensive income is disclosed should have no effect. However, experimental behavioural research examining this question suggests that financial statement users (mostly analysts) use comprehensive income depending on the format and location of its disclosure in the financial statements. Hirst and Hopkins (1998) found that financial analysts make use of comprehensive income only when it is reported as a separate statement, but not when it is reported as part of the statement of changes in shareholders' equity. Maines and McDaniel (2000) found that non-professional investors rely more heavily on comprehensive income for evaluating performance when it is reported in a separate statement, and do not use the information much if it is reported in other forms. Research also suggests that a more transparent format (e.g. a separate statement of comprehensive income) reduces the likelihood of managers engaging in earnings management (Hunton et al. 2006).

It has been suggested in the literature that users of financial statements tend to use numbers from the income statement (the "bottom line”) and do not consider disclosure in the balance sheet (changes in equity). This is known as the functional fixation hypothesis (Ashton 1976; Ijiri and Jaedicke 1966; Haka et al. 1986), and although it has been sought to be empirically discredited (Harris and Ohlson 1990), it may yet explain, in part, the greater preference for the income statement, as well as why preparers tend to choose to mostly avoid reporting comprehensive income in either the income statement or as a stand-alone statement, but instead prefer to report it in the statement of changes in equity.

Although reporting location choice could be an important factor determining the usefulness of OCI information, for my current study, I do not include this information. This is because of two reasons. First, Chambers et al (2007) found no statistically significant difference between 
companies using a performance statement format (single or dual comprehensive income statements) or a statement of changes in equity format for reporting OCI. Secondly, Chambers et al (2007) report greater significance for OCI information when reported in a statement of changes in equity. Note that the SCE format is preferred by financial statement preparers in the United States. It could be that financial statement users both expect to and are able to find the information from an SCE. Since HB1530 was modeled after SFAS 130, along with the likelihood that most users (investors, analysts, etc.) would be used to the location choices in the U.S., I expect that results similar to Chambers et al's (2007) would also hold for Canada.

\subsubsection{Research questions}

The objective of this study is to investigate empirically whether mandatory reporting of OCI and its components in Canada, under the CICA HB1530 as part of comprehensive income, has decision usefulness in comparison with, as well as incremental to, net income. By decision usefulness, I mean whether these accounting metrics are incrementally useful for decision making, as evidenced by statistically significant coefficients in multivariate regressions of stock prices and returns on accounting information, including OCI.

The issue of whether OCI meets the definition of income is contentious. Critics of comprehensive income reporting argue that OCI reflects transitory earnings, and hence does not represent core earnings. In other words, OCI adds noise to reported income, is difficult to forecast, and is essentially beyond the scope of managerial control. On the other hand, the

advocates of comprehensive income argue that it is the only measure that captures all sources of value creation as distinguished from value distribution, is most consistent with the residual income model of accounting-based valuation theory, and as such, has the potential to enforce discipline on managers and analysts to consider all factors affecting value (Biddle and Choi 2006). In sum, it is possible that the items of OCI are not transitory in nature. That is, they are both predictable and relevant for forecasting and valuation purposes. If so, we should treat them as valid components of a broad definition of income. If OCI and its components are not transitory, they should be value relevant, and hence useful for decision making. In this study I empirically investigate the following research questions: 
(i) Are components of OCI transitory?

(ii) In Canada, do OCI and its components have incremental value relevance over traditional net income?

(iii) Are OCI and its components associated with analyst' earnings forecasts?

The question of value relevance of OCI has been examined by several authors using data for US companies. Early empirical studies found little compelling evidence to support value relevance. A major reason for the failure of earlier research in finding significant results for OCI and its components could be that earlier research used as-if numbers (researcher calculated) instead of as-reported (reported in financial statements) numbers. Chambers et al. (2007) demonstrated that actual as-reported numbers for OCI are better reflected in stock prices than the as-if numbers, possibly because the latter contain substantial measurement error. For example, Dee (1999) demonstrated one way in which measurement error might creep in when data from archival sources such as Compustat is used without proper screening. Compustat reports a value if companies report the data separately on their balance sheet, but not if they report it in a statement of shareholders' equity or as a footnote. However, earlier studies examining value relevance of comprehensive income reporting used as-if numbers calculated by putting together line items pulled out from archival databases instead of actual reported data. For most of the earlier studies, this compromise was necessary, because they sought to examine the issue using data from time periods prior to the implementation of mandatory comprehensive income reporting.

With more companies formally reporting data on OCI under SFAS 130, empirical studies dating later than 2006 began reporting evidence supportive of value relevance of OCI. Given that Canada has an institutional context similar to the United States, the question arises why a study using data from Canadian companies could be sufficiently different to be of interest. In response to this question, it might be argued that the adoption of comprehensive income reporting in Canada did not enhance clean surplus accounting. Instead, some items which were included in the income statement (and hence summarized by net income) before the adoption of HB1530 were later required to be stated separately as OCI. Doing so could have made the earnings 
information noisier, and hence led to reduced value relevance. In that case comprehensive income could be less decision useful than net income. On the other hand, if treasury management (managing investments) and risk management (hedging) are considered by financial statement users to be important activities from a stewardship perspective, separate disclosure on these items may well be incrementally informative (Venkatachalam 1996; Kanagaretnam et al. 2009). Further, with increasing globalization, and a commodities driven appreciation of the Canadian dollar relative to major foreign currencies including the US dollar, it is possible that gains and losses arising from foreign currency translations may be value relevant. Alternatively, despite recent evidence supporting the usefulness of OCI and its components in the United States, the same might not hold true for Canada.

\subsection{Contribution to the literature}

This study provides direct empirical evidence on the decision usefulness or otherwise of mandatory comprehensive reporting in Canada. Of course, following Skinner (1999) it could be argued that sophisticated investors might probably not consider components of OCI, because they are transitory in nature, in that they are unpredictable, irrelevant for predicting future earnings and hence, value irrelevant. This study addresses this concern by testing whether components of other comprehensive income are transitory. Jones and Smith (2011) is the only other study that I am aware of that examines this issue in detail. Jones and Smith (2011) use data on U.S. firms to jointly estimate the value relevance, predictive value, and persistence of OCI gains and losses. They conclude that OCI is value relevant, display negative persistence by partially reversing over time and have predictive value in terms of its ability to predict future operating income and cash flows. My study examines the issue of predictive value and persistence by using the specifications described in Ohlson (1999). In doing so, it provides evidence complementary to Jones and Smith (2011). The current study also goes beyond value relevance studies in examining the association between OCI and analysts' earnings forecasts.

Ohlson (1999) pointed out that due to its lack of persistence, transitory earnings should only be incorporated into price on a dollar-for-dollar basis, insofar as it results in a change in a company's book value only in the current year, and is not expected to persist in the future. It 
should be interesting to examine if this is the case in the Canadian context, or whether comprehensive income is a superior predictor of stock prices and returns than net income. Using both level (valuation) and change (returns) regressions this study provides empirical evidence in the Canadian context.

This study also uses actually reported data following the coming into effect of HB1530 for firm years commencing from October 2006 onwards. It should help allay concerns of measurement error that may have caused mixed results in earlier studies, while also providing more recent empirical evidence on Kanagaretnam et al.’s (2009) finding of significant association between components of OCI and share price as well as market returns for the 19982003 period for Canadian firms.

Lastly, this study examines whether components of other comprehensive income are associated with analysts' earnings forecasts, and their effect on analysts' forecast errors. Often, investors rely on analysts' recommendations in making their investment decisions. These recommendations may at times be affected by the analysts’ predispositions towards certain accounting information (the functional fixation hypothesis), which therefore, indirectly condition the market's reaction to the information - in this case, comprehensive income.

A number of studies examining the value-relevance of comprehensive income and other comprehensive income have been published. The findings of extant research on the subject may help condition the expectations for Canada. The following chapter provides an overview of the literature related to the usefulness / value relevance of comprehensive income. 


\section{Chapter Three: Literature Review}

In this chapter I review the literature related to my research questions. Section 3.1 reviews studies examining whether $\mathrm{OCI}$ is transitory. Section 3.2 reviews the literature examining the value relevance and usefulness of comprehensive income. Subsection 3.2.1 summarizes early studies, while subsection 3.2.2 reviews more recent studies. Subsection 3.2.3 summarizes the only study of the value relevance of OCI that uses Canadian data. My intention in splitting section 3.2 is to contrast the results of the earlier studies with those of the recent ones, as well as highlight the findings from Canada. Section 3.3 reviews studies examining analysts' earnings forecasts. I did not come across any study which directly examined the use of OCI by stock analysts. However, I believe a general review of the literature's basic findings would be helpful in evaluating my results. Finally, section 3.4 discusses the implications of the existing literature for my study. Table 3.1 below summarizes the studies covered in the following literature review.

Table 3-1: Summary of literature review of selected studies examining some aspect of usefulness of comprehensive income, OCI or components

\begin{tabular}{|c|c|c|c|c|}
\hline Reference & Data & Research question & Data and method & Key result(s) \\
\hline $\begin{array}{l}\text { Cheng, Cheung } \\
\text { and } \\
\text { Gopalakrishnan } \\
\text { (1993) }\end{array}$ & U.S. & $\begin{array}{l}\text { Comparative usefulness } \\
\text { of three earnings } \\
\text { measures - operating } \\
\text { income, net income and } \\
\text { comprehensive income }\end{array}$ & $\begin{array}{l}\text { Average of } 922 \text { firms for } \\
18 \text { years. } \\
\text { Compared r-squareds for } \\
\text { the earnings measures. } \\
\text { Defined comprehensive } \\
\text { income as equal to change } \\
\text { in retained earnings + } \\
\text { preferred dividends + } \\
\text { common dividends }\end{array}$ & $\begin{array}{l}\text { The adjusted r-squaredd } \\
\text { for Operating income } \\
\left(\mathrm{R}^{2} \text { OI }\right) \text { was greater than } \\
\text { that for net income }\left(\mathrm{R}^{2}{ }_{\mathrm{NI}}\right) \text {, } \\
\text { which in turn was greater } \\
\text { than for comprehensive } \\
\text { income }\left(\mathrm{R}_{\mathrm{CI}}^{2}\right) \rightarrow \\
\text { Comprehensive income is } \\
\text { less useful. }\end{array}$ \\
\hline $\begin{array}{l}\text { Hirst and } \\
\text { Hopkins (1998) }\end{array}$ & U.S. & $\begin{array}{l}\text { Does reporting of } \\
\text { comprehensive income } \\
\text { and its components } \\
\text { facilitate detection of } \\
\text { earnings management } \\
\text { by buy-side financial } \\
\text { analysts? }\end{array}$ & $\begin{array}{l}\text { 3x2 between subjects } \\
\text { experimental design } \\
96 \text { buy-side security } \\
\text { analysts and portfolio } \\
\text { managers not specializing } \\
\text { in banking, insurance or } \\
\text { financial industries. }\end{array}$ & $\begin{array}{l}\text { Clear display of } \\
\text { comprehensive income } \\
\text { and its components in a } \\
\text { separate performance } \\
\text { statement made earnings } \\
\text { management more } \\
\text { transparent. Disclosure in } \\
\text { a statement of changes in } \\
\text { equity was not as } \\
\text { effective. }\end{array}$ \\
\hline
\end{tabular}




\begin{tabular}{|c|c|c|c|c|}
\hline Reference & Data & Research question & Data and method & Key result(s) \\
\hline $\begin{array}{l}\text { Dhaliwal, } \\
\text { Subramanyam } \\
\text { and Trezevant } \\
\text { (1999) }\end{array}$ & U.S. & $\begin{array}{l}\text { Compare the relative } \\
\text { ability of } \\
\text { comprehensive income } \\
\text { and net income to } \\
\text { summarize firm } \\
\text { performance } \\
\text { (association with stock } \\
\text { returns) and market } \\
\text { value of equity }\end{array}$ & $\begin{array}{l}\text { 11,000-plus firm-years for } \\
\text { the years } 1994 \text { and } 1995 . \\
\text { Value of OCI items } \\
\text { computed by authors (as- } \\
\text { if) }\end{array}$ & $\begin{array}{l}\text { No evidence that } \\
\text { comprehensive income is } \\
\text { more strongly associated } \\
\text { with stock returns, market } \\
\text { value or cash flows than } \\
\text { net income. }\end{array}$ \\
\hline Skinner (1999) & N/A & $\begin{array}{l}\text { Review / critique of } \\
\text { Dhaliwal et al (1999) }\end{array}$ & Not applicable & $\begin{array}{l}\text { Questions the motivation } \\
\text { for Dhaliwal et al (1999); } \\
\text { does not find the results } \\
\text { either interesting or } \\
\text { surprising. }\end{array}$ \\
\hline Dee (1999) & U.S. & $\begin{array}{l}\text { Relative usefulness of } \\
\text { net income and } \\
\text { comprehensive income } \\
\text { in modeling firm value }\end{array}$ & $\begin{array}{l}\text { Hand collected data for } \\
126 \text { firms for } 1986-1996 \\
\text { (1,386 firm years) }\end{array}$ & $\begin{array}{l}\text { OCI items are not related } \\
\text { to firm value } \\
\text { OCI items have small } \\
\text { positive autocorrelation } \\
\text { and zero means } \rightarrow \text { they } \\
\text { are transitory }\end{array}$ \\
\hline $\begin{array}{l}\text { Maines and } \\
\text { McDaniel (2000) }\end{array}$ & U.S. & $\begin{array}{l}\text { Does the financial } \\
\text { statement presentation } \\
\text { format affect non- } \\
\text { professional investors' } \\
\text { judgment of } \\
\text { comprehensive income }\end{array}$ & $\begin{array}{l}\text { Experiment using } 95 \\
\text { MBA students; } 3 x 2 \\
\text { between-subjects design }\end{array}$ & $\begin{array}{l}\text { Nonprofessional investors } \\
\text { rely more on information } \\
\text { provided in a performance } \\
\text { statement (Statement of } \\
\text { Comprehensive Income) } \\
\text { than in other presentation } \\
\text { formats. }\end{array}$ \\
\hline Louis (2003) & U.S. & $\begin{array}{l}\text { Value relevance of } \\
\text { foreign translation } \\
\text { adjustment }\end{array}$ & 4,972 firm years & $\begin{array}{l}\text { Translation adjustment is } \\
\text { significantly but } \\
\text { negatively associated with } \\
\text { firm value }\end{array}$ \\
\hline $\begin{array}{l}\text { O'Hanlon and } \\
\text { Pope (1999) }\end{array}$ & U.K. & $\begin{array}{l}\text { Value relevance of UK } \\
\text { dirty surplus accounting } \\
\text { flows }\end{array}$ & $\begin{array}{l}158 \text { firms with data for } 20 \\
\text { years (1973-1992); test } \\
\text { association in the short- } \\
\text { and the long-intervals } \\
\text { between stock returns and } \\
\text { accounting flows } \\
\text { (operating profit, } \\
\text { extraordinary items and } \\
\text { dirty surplus items) }\end{array}$ & $\begin{array}{l}\text { Operating profit is value- } \\
\text { relevant in the short- and } \\
\text { long-intervals } \\
\text { Extraordinary items are } \\
\text { value-relevant in long- } \\
\text { interval tests only } \\
\text { Dirty surplus items (items } \\
\text { bypassing the income } \\
\text { statement) are not value- } \\
\text { relevant }\end{array}$ \\
\hline
\end{tabular}




\begin{tabular}{|c|c|c|c|c|}
\hline Reference & Data & Research question & Data and method & Key result(s) \\
\hline \multirow[t]{3}{*}{$\begin{array}{l}\text { Brimble and } \\
\text { Hodgson (2004) }\end{array}$} & \multirow[t]{3}{*}{ Australia } & \multirow[t]{3}{*}{$\begin{array}{l}\text { Value relevance of } \\
\text { comprehensive income } \\
\text { and components }\end{array}$} & $\begin{array}{l}\text { Defined comprehensive } \\
\text { income as ordinary net } \\
\text { income, extraordinary } \\
\text { items, change in asset } \\
\text { revaluation reserve, } \\
\text { foreign currency } \\
\text { translation and sundry } \\
\text { (dirty surplus) items }\end{array}$ & $\begin{array}{l}\text { Net income from ordinary } \\
\text { operations dominates } \\
\text { comprehensive income as } \\
\text { the more value relevant } \\
\text { metric. } \\
\text { Components of OCI are } \\
\text { not value relevant. }\end{array}$ \\
\hline & & & $\begin{array}{l}\text { Used linear and non-linear } \\
\text { (arctan) regression } \\
\text { models }\end{array}$ & \\
\hline & & & $\begin{array}{l}\text { Australian data for } 92 \\
\text { companies for years 1988- } \\
1997 \text { (920 observations) }\end{array}$ & \\
\hline \multirow[t]{4}{*}{$\begin{array}{l}\text { Biddle and Choi } \\
\text { (2006) }\end{array}$} & \multirow[t]{4}{*}{ U.S. } & \multirow[t]{4}{*}{$\begin{array}{l}\text { Is comprehensive } \\
\text { income useful? }\end{array}$} & \multirow{3}{*}{$\begin{array}{l}\text { Uses five definitions for } \\
\text { usefulness (information } \\
\text { content, predictive ability, } \\
\text { use in compensation } \\
\text { contracting, relative } \\
\text { usefulness in the } \\
\text { preceding three contexts, } \\
\text { and whether separate } \\
\text { disclosure of income } \\
\text { components is useful) and } \\
16 \text { definitions of income }\end{array}$} & $\begin{array}{l}\text { Comprehensive income } \\
\text { has greater information } \\
\text { content for equity returns } \\
\text { than net income }\end{array}$ \\
\hline & & & & $\begin{array}{l}\text { Broadly defined net } \\
\text { income has the greatest } \\
\text { predictive ability }\end{array}$ \\
\hline & & & & $\begin{array}{l}\text { Some components of OCI } \\
\text { are relevant for executive } \\
\text { compensation contracts }\end{array}$ \\
\hline & & & $\begin{array}{l}\text { Approximately } 18,700 \\
\text { observations, US firms }\end{array}$ & $\begin{array}{l}\text { More comprehensive } \\
\text { definitions of income are } \\
\text { more useful, and it is } \\
\text { decision useful to } \\
\text { separately disclose } \\
\text { components of } \\
\text { comprehensive income }\end{array}$ \\
\hline
\end{tabular}




\begin{tabular}{|c|c|c|c|c|}
\hline Reference & Data & Research question & Data and method & Key result(s) \\
\hline \multirow[t]{3}{*}{$\begin{array}{l}\text { Choi and Zang } \\
\text { (2006) }\end{array}$} & \multirow[t]{3}{*}{ U.S. } & \multirow{3}{*}{$\begin{array}{l}\text { Is comprehensive } \\
\text { income associated with } \\
\text { subsequent period net } \\
\text { income and with } \\
\text { analysts' earnings } \\
\text { forecasts/forecast } \\
\text { revisions/forecast } \\
\text { errors? }\end{array}$} & $\begin{array}{l}\text { Assumes that OCI helps } \\
\text { managers in the timing } \\
\text { and recognition of } \\
\text { unrealized gains and } \\
\text { losses. }\end{array}$ & $\begin{array}{l}\text { Comprehensive income } \\
\text { can predict subsequent } \\
\text { period net income } \\
\text { incremental to current net } \\
\text { income. }\end{array}$ \\
\hline & & & $\begin{array}{l}\text { Control for size (minimum } \\
\text { stock price of \$5) and } \\
\text { materiality of OCI } \\
\text { (absolute value of OCI > } \\
0.1 \% \text { of beginning of year } \\
\text { stock price) }\end{array}$ & $\begin{array}{l}\text { Managers use discretion in } \\
\text { timing of recognition of } \\
\text { components of OCI when } \\
\text { these relate to unrealized } \\
\text { losses. }\end{array}$ \\
\hline & & & $\begin{array}{l}\text { Stock price) } \\
\text { Approximately 5,200 } \\
\text { observations obtained } \\
\text { from IBES }\end{array}$ & $\begin{array}{l}\text { If comprehensive income } \\
\text { is less than net income } \\
\text { (i.e. AOCI represents } \\
\text { unrealized losses), } \\
\text { analysts revise their } \\
\text { forecasts downwards more } \\
\text { than when the opposite } \\
\text { situation holds } \rightarrow \\
\text { asymmetry in usefulness. }\end{array}$ \\
\hline \multirow[t]{2}{*}{$\begin{array}{l}\text { Choi, Das and } \\
\text { Zang (2007) }\end{array}$} & \multirow[t]{2}{*}{ U.S. } & \multirow{2}{*}{$\begin{array}{l}\text { Is OCI associated with } \\
\text { subsequent period } \\
\text { income and is this } \\
\text { association is reflected } \\
\text { in stock prices? }\end{array}$} & $\begin{array}{l}\text { 15,977 firm-year } \\
\text { observations for } 3,716 \text { US } \\
\text { firms }\end{array}$ & $\begin{array}{l}\text { OCI is incrementally } \\
\text { useful in predicting } \\
\text { subsequent period net } \\
\text { income }\end{array}$ \\
\hline & & & $\begin{array}{l}\text { Use components for OCI } \\
\text { as defined under SFAS } \\
130 \text {. Control variables } \\
\text { include natural logs of } \\
\text { market value of equity, } \\
\text { book-to-market ratio, } \\
\text { accruals, security-beta and } \\
\text { earnings-to-price ratio }\end{array}$ & $\begin{array}{l}\text { The market does not } \\
\text { impound the information } \\
\text { in OCI in stock price. A } \\
\text { zero-investment strategy } \\
\text { based on current period } \\
\text { OCI yields an abnormal } \\
\text { return of } 5.4 \% \text { even after } \\
\text { controlling for other } \\
\text { correlated variables. }\end{array}$ \\
\hline
\end{tabular}




\begin{tabular}{|c|c|c|c|c|}
\hline Reference & Data & Research question & Data and method & Key result(s) \\
\hline $\begin{array}{l}\text { Lee, Petroni and } \\
\text { Shen (2006) }\end{array}$ & U.S. & $\begin{array}{l}\text { Do reporting choices for } \\
\text { comprehensive income } \\
\text { represent opportunities } \\
\text { for cherry picking } \\
\text { securities gains and } \\
\text { losses? }\end{array}$ & $\begin{array}{l}\text { Analyze reporting } \\
\text { decisions of } 82 \text { publicly } \\
\text { traded property insurance } \\
\text { companies }\end{array}$ & $\begin{array}{l}\text { Identify } 23 \text { companies as } \\
\text { cherry pickers } \\
\text { Cherry pickers are less } \\
\text { likely to report } \\
\text { comprehensive income in } \\
\text { a performance statement } \\
\text { Companies that report } \\
\text { comprehensive income in } \\
\text { a performance statements } \\
\text { have a tendency to not } \\
\text { smooth earnings, have a } \\
\text { reputation for high-quality } \\
\text { disclosures, and an auditor } \\
\text { that ranks among the top- } \\
\text { two in the insurance } \\
\text { industry }\end{array}$ \\
\hline $\begin{array}{l}\text { Bamber, Jiang, } \\
\text { Petroni and } \\
\text { Wang (2010) }\end{array}$ & U.S. & $\begin{array}{l}\text { Which factors explain } \\
\text { the reporting choices of } \\
\text { firms regarding } \\
\text { comprehensive income? }\end{array}$ & $\begin{array}{l}\text { Analyze comment letters } \\
\text { on the exposure draft for } \\
\text { SFAS 130, surveys and } \\
\text { behavioural research } \\
\text { Identify equity-based } \\
\text { incentives and concerns } \\
\text { for job security as two } \\
\text { major factors driving } \\
\text { comprehensive income } \\
\text { reporting choice } \\
\text { Reporting choices of } 440 \\
\text { firms for the years } 1998- \\
2001 \\
\text { Use logit model to test } \\
\text { hypotheses }\end{array}$ & $\begin{array}{l}\text { Managers with more } \\
\text { equity-based incentives (or } \\
\text { more job security } \\
\text { concerns) tend to avoid } \\
\text { reporting comprehensive } \\
\text { income in a performance } \\
\text { statement. } \\
\text { Analysis of comment } \\
\text { letters suggests that } \\
\text { managers were concerned } \\
\text { that stakeholders would } \\
\text { negatively perceive } \\
\text { comprehensive income's } \\
\text { higher volatility compared } \\
\text { to net income }\end{array}$ \\
\hline
\end{tabular}




\begin{tabular}{|c|c|c|c|c|}
\hline Reference & Data & Research question & Data and method & Key result(s) \\
\hline \multirow[t]{5}{*}{$\begin{array}{l}\text { Chambers, } \\
\text { Linsmeier, } \\
\text { Shakespeare and } \\
\text { Sougiannis } \\
\text { (2007) }\end{array}$} & \multirow[t]{5}{*}{ U.S. } & $\begin{array}{l}\text { Are OCI components } \\
\text { priced by investors? } \\
\text { Are OCI components } \\
\text { transitory? }\end{array}$ & \multirow{5}{*}{$\begin{array}{l}\text { 1,727 firm-years (as-if } \\
\text { data) for pre-SFAS } 130 \\
\text { years (1994-1997) and } \\
2,807 \text { firm-years (as- } \\
\text { reported data) for post } \\
\text { SFAS-130 period (1998- } \\
2003 \text { ) }\end{array}$} & $\begin{array}{l}\text { In the pre-SFAS } 130 \\
\text { period, OCI was not } \\
\text { priced. However, it was } \\
\text { priced by investors in the } \\
\text { post-SFAS } 130 \text { period. }\end{array}$ \\
\hline & & \multirow[t]{4}{*}{$\begin{array}{l}\text { Does the reporting } \\
\text { location preference } \\
\text { matter? }\end{array}$} & & $\begin{array}{l}\text { As-if data contained } \\
\text { significant measurement } \\
\text { error }\end{array}$ \\
\hline & & & & $\begin{array}{l}\text { Coefficients on OCI } \\
\text { components are not } \\
\text { significantly different } \\
\text { from } 1 \text { (implying they are } \\
\text { transitory), except for } \\
\text { MKTADJ, the coefficient } \\
\text { for which is significantly } \\
\text { greater than } 1 \text { (implying } \\
\text { persistence) }\end{array}$ \\
\hline & & & & $\begin{array}{l}\text { Reporting preferences } \\
\text { appear to vary by industry }\end{array}$ \\
\hline & & & & $\begin{array}{l}\text { The expected location } \\
\text { choice (statement of } \\
\text { changes in equity) appears } \\
\text { to receive greater attention } \\
\text { from investors than the } \\
\text { standard-setters' preferred } \\
\text { choice (statement of } \\
\text { comprehensive income) }\end{array}$ \\
\hline \multirow[t]{2}{*}{$\begin{array}{l}\text { Kanagaretnam, } \\
\text { Mathieu and } \\
\text { Shehata (2009) }\end{array}$} & \multirow[t]{2}{*}{ Canadian } & \multirow[t]{2}{*}{$\begin{array}{l}\text { Usefulness of } \\
\text { comprehensive income } \\
\text { reporting in Canada }\end{array}$} & \multirow{2}{*}{$\begin{array}{l}228 \text { firm-year } \\
\text { observations for } 75 \\
\text { Canadian firms cross- } \\
\text { listed on US stock } \\
\text { exchanges. } \\
\text { Valuation and returns } \\
\text { regressions used }\end{array}$} & $\begin{array}{l}\text { Unrealized gains and } \\
\text { losses on available for sale } \\
\text { securities and on cash flow } \\
\text { hedges are value relevant }\end{array}$ \\
\hline & & & & $\begin{array}{l}\text { more strongly associated } \\
\text { with stock price and } \\
\text { returns than is net income, } \\
\text { and is also a better } \\
\text { predictor of future cash } \\
\text { flows. }\end{array}$ \\
\hline
\end{tabular}




\begin{tabular}{|c|c|c|c|c|}
\hline Reference & Data & Research question & Data and method & Key result(s) \\
\hline \multirow[t]{3}{*}{$\begin{array}{l}\text { Jones and Smith } \\
\text { (2011) }\end{array}$} & \multirow[t]{3}{*}{ U.S. } & \multirow{3}{*}{$\begin{array}{l}\text { Comparison of the value } \\
\text { relevance, predictive } \\
\text { value and persistence of } \\
\text { OCI and special } \\
\text { (irregular or } \\
\text { extraordinary) items }\end{array}$} & $\begin{array}{l}236 \text { companies reporting } \\
\text { non-zero OCI for each } \\
\text { year during } 1986-2005 \\
(4,720 \text { observations })\end{array}$ & $\begin{array}{l}\text { OCI is value relevant, but } \\
\text { less so than continuing net } \\
\text { income or even special } \\
\text { items }\end{array}$ \\
\hline & & & \multirow{2}{*}{$\begin{array}{l}\text { Use Seemingly Unrelated } \\
\text { Regressions approach to } \\
\text { estimate dynamic } \\
\text { responses capturing } \\
\text { marginal effects of shocks } \\
\text { to OCI and special items }\end{array}$} & $\begin{array}{l}\text { OCI is negatively } \\
\text { persistent, at least for three } \\
\text { years }\end{array}$ \\
\hline & & & & $\begin{array}{l}\text { OCI has incremental } \\
\text { ability to predict future } \\
\text { continuing net income for } \\
\text { one year, as well as future } \\
\text { cash flows }\end{array}$ \\
\hline
\end{tabular}

\subsection{Studies examining whether other comprehensive income is transitory}

Barth et al (1999) were amongst the first to test attributes of earnings components using the framework developed by Ohlson (1999). They examined the value relevance of accruals and cash flows in terms of their ability to predict future abnormal earnings incremental to abnormal earnings. They defined abnormal earnings, $N I_{t}^{a}=N I_{t}{ }^{-} r^{*} B V_{t-1}$ where $N I_{t}$ is income from continuing operations, and BV is book value of equity. They set $r=12$ per cent, the long-term return on equities. They asserted that they tested their model using alternative values for $r$, with no change in their conclusions. Barth et al (1999) concluded that the interaction between forecasting relevance and persistence resulted in different valuations for the accrual and cashflow components of earnings.

Chambers et al (2007) cited an unpublished article by Hillegeist and Penalva (1999) who find that coefficients on OCI and its components are not stable over time. Chambers et al (2007) ran sensitivity tests using 100 random pooled sub-samples, and report that whereas coefficients for year-by-year regressions were unstable, the results are stable when pooled over longer periods. The stability of pooled regression coefficients on OCI and its components suggests that they are possibly not transitory.

Chambers et al (2007) also checked serial correlations for OCI and its components. They found that $a$ s-if values for OCI (i.e. values computed by the researchers) had a significantly negative serial correlation, whereas all as-reported values (i.e. values obtained from companies' 
annual reports) had insignificant serial correlation except for unrealized gains and losses on available for sale securities. Dismissing their finding of significant serial correlation in as-if values to be due to measurement error, Chambers et al (2007) concluded that OCI and its components were transitory in nature. This result, of course, is at odds with their earlier suggestion that OCI might not be transitory. It should be interesting to re-examine this issue using actually reported numbers.

Another puzzling result reported by Chambers et al (2007) was that the coefficient on one of the components of OCI, the unrealized gain or loss on available for securities (called MKTADJ by Chambers et al) was not only significantly greater than one ${ }^{11}$, but it also turned out to be significantly greater than the coefficient on Net Income. The result is puzzling, because it seems to suggest that the variable MKTADJ has greater persistence than net income. Typically, earnings components with high persistence should possess significantly positive serial correlation. In contrast, Chambers et al (2007) reported a significantly negative serial correlation in as-reported MKTADJ. This implies that although unrealized gains and losses show a tendency to reverse in future years, they appear to be priced as persistent earnings items. One explanation for the negative serial correlation could be that firms might be locking onto the gains and losses in the following years, and moving them to net income following the practice of recycling of OCI. Under this practice, when the underlying asset is sold, any OCI related to it is reclassified as a realized gain or loss, and included in Net Income. As for Chambers et al's (2007) finding that the coefficient for MKTADJ is greater than that for NI, no convincing explanation is available. To rule out the possibility that this result was idiosyncratic to their data, it would be interesting to reexamine the relationship using an alternative sample.

Jones and Smith (2011) used a model that jointly estimates value relevance, predictive value, and persistence to study OCI and Special Items (SI). They found that whereas SI are transitory, OCI gains and losses exhibit negative persistence. They also found that items of OCI are autocorrelated with their lagged values, indicating persistence. Jones and Smith (2011) also

\footnotetext{
${ }^{11}$ Ohlson (1999) predicted that transitory earnings are priced on a dollar-for-dollar basis due to their lack of persistence.
} 
reported that the sign of significant serial correlation for OCI and components is not stable. This raises the possibility that Chambers et al's (2007) findings regarding serial correlation on OCI variables might be a function of the time period of their sample. A similar argument could apply to Jones and Smith (2011) as well. In empirically testing the issue by using Ohlson’s (1999) regressions, in this study, I seek to provide further evidence one way or the other.

\subsection{Studies examining the value relevance of comprehensive income}

Several studies have examined the value relevance of comprehensive income reporting in different settings, including the USA (Chambers et al. 2007; Choi and Zang 2006; Dee 1999; Biddle and Choi 2006; Dhaliwal et al. 1999), Europe (Goncharov and Hodgson 2011), the UK (O'Hanlon and Pope 1999), New Zealand (Cahan et al. 2000), Japan (Kubota et al. 2006) and Canada (Kanagaretnam et al. 2009). The earlier studies used as-if data and did not find much support for the value relevance of OCI. Later studies, from the mid-2000s were able to use asreported data, and reported finding value relevance for at least some components of OCI. The following is a brief description of the major studies examining the value relevance of comprehensive income.

\subsubsection{Early studies}

Comprehensive income reporting was of interest not only in the U.S., but also in other countries. For example, financial reporting standards requiring comprehensive income reporting were issued by the accounting standards boards of the UK (FRS 3, 1992), New Zealand (FRS 2, 1994), and the IASC (IAS 1, 1997). However, direct comparisons may be somewhat misleading, as the respective GAAPs are different in their treatment of certain items. For example, under New Zealand FRS 2, revaluation of assets is permitted, and is reported in a statement of changes in equity. Under IFRS, companies are permitted to use the revaluation model to account for property, plant and equipment, with any increase in asset values reported in other comprehensive income. Asset revaluation was not permitted under Canadian GAAP, and is not allowed under the U.S. GAAP. Nevertheless, both U.S. and non-U.S. empirical research is informative about the perceived usefulness of comprehensive income reporting. Early studies found little evidence on the value relevance of comprehensive income and its components. 
Cheng, Cheung and Gopalakrishnan (1993) evaluated the usefulness of operating income, net income and comprehensive income. They defined usefulness as "the goodness-of-fit (adjusted rsquared) in the regression of residual stock returns on earnings” (p 195) and based their analysis on 18 years of annual data from 1972 to 1989. They reported their results in terms of relative information content as well as incremental information content of the three competing earnings measures. They concluded that in terms of relative information content, operating income (OI) dominates net income (NI), which in turn dominates comprehensive income (CI) (p 199). In terms of incremental information content, where they tested the hypotheses of equality of rsquareds, they again found that the r-squared for OI was greater than that for NI, which in turn was greater than the r-squared for CI. Interpreting their results for the usefulness of comprehensive income, Cheng et al. (1993) noted that while they found "very little incremental explanatory power attributable to those earnings items that account for the difference between comprehensive income and net income... one could (also) interpret the results as suggesting that investors are fixated on net income” (p 202). Cheng et al.’s (1993) study predated the actual implementation of SFAS 130 by a few years, and their definition of comprehensive income (Change in Retained Earnings + Preferred Dividends + Common Dividends) was different from what the standard recommended (Net Income + OCI).

Dhaliwal, Subramanyam and Trezevant (1999) computed comprehensive income under SFAS $130\left(\mathrm{COMP}_{130}\right)^{12}$ as well as a broader measure $\left(\mathrm{COMP}_{\text {broad }}\right)^{13}$, and tested the relative value relevance of these measures as well as net income after extraordinary items and discontinued operations (NI) by regressing raw daily percentage returns compounded over the fiscal year on each of these earnings measures. Requiring Compustat and CRSP data needed to calculate returns, NI, COMP broad $_{\text {and }} \mathrm{COMP}_{130}$, they used a sample consisting of all 1994 and

\footnotetext{
12 At the time of Dhaliwal et al's (1999) study, under SFAS 130, the three items included in Other comprehensive income were (i) the change in the balance of unrealized gains and losses on marketable securities (MKT-ADJ), (ii) the change in the cumulative foreign currency translation adjustment (FC-ADJ), and (iii) the change in additional minimum pension liability in excess of unrecognized prior service costs (PENS-ADJ)

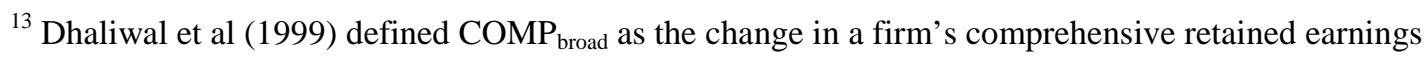
(COMPUSTAT item \#36), adjusted for common stock dividends.
} 
1995 firm years ${ }^{14}$. Consistent with Cheng et al. (1993), Dhaliwal et al. (1999) reported "no clear evidence that comprehensive income is on average more strongly associated with returns than (is) net income” (p64). Of the various components of other comprehensive income (OCI) described in SFAS 130, Dhaliwal et al. (1999) found only marketable securities adjustments improve the association between net income and stock returns, but even this finding is shown to be driven by financial sector firms.

Skinner (1999) in a critique of Dhaliwal et al. (1999) raised several concerns for research into value relevance of comprehensive income. Skinner (1999) argued that comprehensive income amounts to little more than reclassification of income, and as such does not bring in new information. In Skinner's (1999) opinion, past changes in the value of investments have no implications for future cash flows and earnings. Therefore, he argued that in the absence of such implications, it was not clear why comprehensive income should be expected to be more highly correlated with stock returns than net income. Skinner (1999) felt that the main problem with the Dhaliwal et al. (1999) study was inadequate motivation, in that the study sought to provide empirical tests for SFAS 130, a standard that Skinner (1999) considered as having very little economic justification. In Skinner's opinion, given the definition of comprehensive income, and the fact that stock market investors were more likely to prefer a current operating performance approach (operating income) to an all-inclusive approach (comprehensive income), it was not surprising that Dhaliwal et al. (1999) got the results they did. Given Ohlson's (1999) exposition of a residual income valuation theory of transitory earnings in which he suggested that the components of other comprehensive income are transitory earnings, which are characterized as being unpredictable, forecast irrelevant and value irrelevant, Skinner's (1999) criticism appears valid. There is little ex-ante reason to expect value relevance for OCI, if it is transitory.

Dee (1999) argued that if comprehensive income includes more transitory items than net income, it should be less useful than net income in valuing a firm. She used hand-collected data for 126 firms over 11 years (1986-1996) and regressed annual returns excluding dividends on NI

\footnotetext{
${ }^{14}$ Data required for computing the change in balance of unrealized gains and losses on marketable securities (MKTADJ) were not available until 1994.
} 
and CI variables. Although none of her r-squareds was larger than 10 percent, the largest rsquared was for a simplified model regressing annual returns on change in NI and gross OCI, where she found only NI to be statistically significant. Using Operating Income (OI) as a predictor, Dee (1999) obtained the largest r-squared (11.6 percent) for a simplified model regressing annual returns on change in OI, after controlling for the market rate of return. Thus, Dee (1999) appeared to corroborate Cheng et al.’s (1993) finding of the dominance of operating income over net income, and that of net income over comprehensive income.

An important point made by Dee (1999), and later picked up by Chambers et al. (2007), is the problem of omission of data from archival sources such as Compustat when the data are not clearly disclosed in the balance sheet, but are instead disclosed by way of footnotes or in a statement of equity. Another important observation by Dee (1999) is that "items of OCI are found to exhibit small positive autocorrelation and have zero means. This is consistent with the prediction that items of OCI are transitory”.

Louis (2001, 2003) examined the value relevance of one component of OCI in particular, the foreign currency translation adjustment (which he refers to as $\mathrm{FCT}_{\mathrm{adj}}$, and is called FOREX in this study), and OCI in general. Louis $(2001,2003)$ argued that although it was claimed that comprehensive income is a better statistic of a firm's performance because it identifies all sources of value added, the economics of FCT adj suggest otherwise. Louis $(2001,2003)$ predicted, and found, that $\mathrm{FCT}_{\text {adj }}$ is negatively associated with firm value, implying that while the adjustment is value relevant, it is not in the direction of the adjustment. For example, a firm might have a negative effect of foreign currency translation due to depreciation of the foreign currency (assuming that the foreign currency is the functional currency), while the overall effect on firm value may still be positive, because the firm would now be able to produce in the foreign country at a cheaper cost than before. Louis $(2001,2003)$ also reported evidence suggesting that items of OCI in general negatively affect the value relevance of the income number. On the basis of earnings persistence and earnings response coefficient, the reported net income is superior to both comprehensive income and net income adjusted for $\mathrm{FCT}_{\text {adj }}$. 
O’Hanlon and Pope (1999) use data for United Kingdom companies to examine the relationship between stock returns and dirty surplus accounting flows over long intervals of up to 20 years. Dirty surplus accounting flows here relate to direct adjustments to equity for items such as goodwill-writeoff, asset revaluation, foreign currency translation and extraordinary items. They found ordinary profit (net income) reported under dirty surplus UK GAAP to be value relevant across short- and long-intervals, whereas extraordinary items were found to be value relevant only over long intervals. In other words, while net income is value-relevant for all timeperiods, a dirty surplus item such as extraordinary items was found to be value-relevant only over a long time-period. The implication is that if OCI were to bypass the performance statement, it would potentially not be value relevant.

O’Hanlon and Pope’s results appear consistent with the conclusions of Cahan et al. (2000), who found no evidence that individual OCI items provide information that is incrementally value relevant over net income. This suggests that the statement of changes in equity (SCE) which reported details about dirty surplus items provided no additional value to investors.

Maines and McDaniel (2000) examined whether non-professional investors' use of comprehensive income information depends on the financial statement in which it is reported. They used a 3x2 between-subjects experiment on 95 MBA students with an average of less than six years of accumulated personal investment and business experience. Participants were given materials related to one of two versions of an insurance company that reported high or low unrealized gains and losses (UGL) volatility over a three-year time period, presented in one of three forms - (1) as per SFAS 115 as change in equity; (2) as per SFAS 130 as change in equity; and (3) as per SFAS 130 as part of income statement. Maines and McDaniel (2000) reported that although participants read the information and appropriately evaluated the volatility of the UGL in all three formats, they placed significant weight on their volatility assessments when UGL appears as part of option (3) above. Under option (3), participants were able to better judge corporate and management performance for the low-volatility version than for the high volatility version. This suggests that non-professional investors rely on financial statements to provide signals about the nature and importance of comprehensive income information, and consider such information important only when it is reported as a stand-alone statement. 
Brimble and Hodgson (2004) reported empirical evidence on the usefulness of comprehensive income in the Australian context. They replicated the adjustments for comprehensive income required under IAS 1 as part of the joint project between the IASB and the FASB, using data from 92 firms listed on the Australian Stock Exchange from 1988 to 1997. They compiled three pooled data sets: (i) the ten annual data observations; (ii) aggregating two five-year consecutive non-overlapping periods, 1988-1992 and 1993-1997; and (iii) one ten-year aggregation. Drawing upon the earlier work by Freeman and Tse (1992), Brimble and Hodgson (2004) used linear and non-linear (arctan) regressions to test value relevance of the components of comprehensive income as per the IAS. They found that net income from ordinary operations is the dominant metric over comprehensive income.

In summary, the earlier empirical studies found very little evidence supporting the value relevance or incremental usefulness of comprehensive income over other measures of earnings such as net income or operating income. Experimental behavioural studies appeared to support Russo's (1977) observation: “it is not sufficient that the information be available; it must also be processable”15 (p 194, quoted by Hirst and Hopkins, 1998; p 57).

\subsubsection{Recent studies}

Recent studies have revisited the question of usefulness of comprehensive income disclosures, providing results different from those of the earlier studies. Biddle and Choi (2006) examined the decision usefulness of sixteen different definitions of income in terms of information content, predictive ability and executive compensation contracting, using data for US firms. They reported that among the different income definitions, the FASB's definition for comprehensive income under SFAS 130 dominates traditional net income as well as other conceptions of income in explaining stock returns. Net income, on the other hand, is better at

\footnotetext{
${ }^{15}$ Russo's (1977) comment was on the display format of unit prices. However, the comment is equally valid in almost all situations where information processing is required. It does assume bounded rationality and limited information processing capacity on the parts of the users of the information. It may, of course, be argued that whereas individuals may have cognitive limitations, the market as a whole, and on an average, is able to accurately process the information. However, in this study, I assume at least a semi-strong form of market efficiency, and hence do not pursue this point.
} 
explaining executive compensation contracting. No single measure of income is found to be superior in terms of relative ability to predict future values of itself..

Choi and Zang (2006) found comprehensive income to be incrementally useful in predicting subsequent period net income. OCI was found to be significantly associated with next period net income, although the improvement in r-squared is marginal (from 14.33 percent to 14.91 percent). In a related paper, Choi, Das and Zang (2007) examined the implication of current period OCI for subsequent period income, and whether the stock market incorporates the current period OCI in stock prices. They found that the market does not reflect the implications of current period OCI for next period net income. They then showed that a one-year, zeroinvestment strategy based on current period OCI yields an abnormal return of around 5 percent after controlling for other correlated variables such as the Fama-French risk factors - log of market value of equity, log of book-to-market ratio, the firm beta (Fama and French 1992), accruals (measured as difference between income before extraordinary items and operating cash flows) and earnings per share deflated by end of year stock price. Choi, Das and Zang (2007) also compared r-squareds for their regressions of next-period net income on current period (1) Net Income; (2) Comprehensive Income; (3) Net income and aggregate OCI; and (4) Net Income and individual OCI components. They found that OCI is incrementally value relevant. However, comparing equation 3 and 4 did not result in a significant improvement in the r-squared, partly because only the securities and foreign currency translation adjustments are statistically significant in equation 4, but the pension adjustment is not. This may well be a result of the (generally) smaller magnitude, and hence insignificant materiality, of OCI numbers.

Lee, Petroni and Shen (2006) studied the comprehensive income reporting choices of property liability insurers. They predicted that firms with greater volatility in their earnings as a result of reporting comprehensive income were more likely to avoid reporting using a performance statement. Although they did not find results to support this prediction, Lee et al. (2006) found that insurers with a tendency to 'cherry-pick' (manage earnings through realized securities gains and losses) as well as insurers with a reputation for poor disclosure quality, are more likely to report comprehensive income in a statement of changes in equity. These firms are also more likely to be audited by an audit-firm that is not one of the top-two specialists in the 
insurance industry. It should be noted here that if insurers did wish to manage reported earnings, it may be easier to manipulate adjustments to reserves than to cherry-pick securities gains and losses. Lee et al (2006) could have merely documented a within-sample association of firms that cherry-pick and prefer not to use the income statement approach to reporting comprehensive income.

In a related study, Bamber, Jiang, Petroni and Wang (2010) investigated the comprehensive income reporting location choice made by S\&P500 firms during the 1998 to 2001 period, and found that firms that disregard policymakers' preferences (i.e. report comprehensive income in a statement of equity instead of in a performance statement as preferred by accounting standard setters) are headed by CEOs with more powerful equity-based incentives and less job-security. Bamber et al (2010) operationalized equity incentive as the change in the CEO's total annual compensation from the firm in response to a one percentage point increase in the firm's stock price. Job security equals the sum of two indicator variables, CEO-chair duality (the CEO is also the chairperson of the board of directors) and board's lack of independence (whether proportion of independent directors in the board is smaller than the sample median). Bamber et al. (2010) reported that a firm's likelihood of reporting comprehensive income in a performance statement is a decreasing (increasing) function of the CEO's equity incentive (job security). Bamber et al (2010) also found that managers with stronger equity-based incentives and less job security are significantly less likely to use performance reporting. Their results are robust to controls for items of OCI, disclosure quality, leverage and size. Only the marketable securities dummy variable was found to be significantly related to comprehensive income reporting location choice. Barring utilities, all other industry dummy variables were also found to be statistically significantly related to the comprehensive income reporting choice, suggesting that industry may be an important variable.

Chambers, Linsmeier, Shakespeare and Sougiannis (2007) followed the theory developed in Ohlson (1999) in their study of valuation usefulness of OCI and its components. Consistent with Ohlson's (1999) proposition that transitory earnings should be valued dollar-for-dollar, Chambers et al. (2007) reported that OCI numbers are positively priced, dollar-for-dollar in the post-SFAS 130 period (i.e. the year 1998 onwards), but not in the earlier period. An important 
reason for this finding is in Chambers et al.’s (2007) use of as-reported (actually reported in statements) figures for the post-SFAS 130 period (1998-2003) as opposed to computed as-if (amounts calculated by the researchers because these were not reported in the statements) numbers for the period prior to 1998. Earlier studies including Dhaliwal et al (1999) had used computed as-if OCI numbers, which could have introduced measurement error into the analyses (Chambers et al. 2007, Table 2 panel C, p576). Chambers et al. (2007) also found that investors price OCI when it is reported in the statement of shareholders' equity. This finding is contrary to the expectation of the FASB (SFAS 130, paragraph 67) that the statement of changes of equity is a less transparent location than the income statement or a separate statement of comprehensive income (p 586). Chambers et al. (2007) also supported the assertion that the location of OCI disclosure matters. They used post-SFAS 130 data to compare the pricing of OCI across two disclosure locations: (i) a statement of financial performance ${ }^{16}$; or (ii) in a statement of changes in equity. Interestingly, over eighty per cent of firms in their sample reported information on OCI in the statement of changes in equity, although the mean and median values for the variables reported were not significantly different from those choosing the performance statement option for reporting OCI. However, the two groups had significantly different beta, book-to-market and earnings-to-price ratios. This finding is consistent Bamber et al's (2010) contention that the location of comprehensive income disclosure matters.

Jones and Smith (2011) is amongst the most recent studies which examine the value relevance of OCI. Jones and Smith jointly tested for the value relevance, predictive value, and persistence of OCI and Special Items (SI). Special Items are infrequent or unusual gains and losses that are separately reported in net income. SI items include realized gains and losses from the sale of assets and investments, unrealized impairment write-offs, and realized or unrealized restructuring charges, merger costs, settlements, and other accrued items. Jones and Smith (2011) is an important study, since many researchers have assumed both OCI and SI to be transitory items. Jones and Smith’s (2011) sample comprises 236 companies in the United States which

\footnotetext{
${ }^{16}$ Under both SFAS 130 and HB1530, companies could report information on comprehensive income in (i) a single Statement of Comprehensive Income; (ii) a separate Statement of Comprehensive Income that begins with Net Income and adds information on OCI items, or (iii) a Statement of Changes in Equity
} 
reported nonzero OCI gains and losses in each year between 1986 and 2005. Part of their data is hand collected, and the remainder is collected from Compustat and CRSP. They found that although OCI and SI are both value relevant, the value relevance of OCI is less in comparison to SI. They also reported that OCI is positively, and significantly, associated with future net income before special items, and future cash flows, albeit less significantly.

In summary, the evidence for the value relevance of OCI and its components continues to be mixed, although recent studies have begun documenting significant results for these numbers. This could be due to a number of possible reasons. First, it could be that earlier research, in using as-if numbers computed by the researchers from extant archival databases, incorporated measurement error (Chambers et al. 2007; Dee 1999). Secondly, it could be that in keeping with the functional fixation hypothesis, initially the analysts and investors continued to use operating income, or net income for their decision making purposes. Financial statement users do not always analyze financial statements in great detail (Hirst et al. 1995), and unless they perceive the information to be important (Brimble and Hodgson 2004; Sanbonmatsu et al. 1997), they tend to rely on simple heuristics (Imhoff et al. 1995). However, gradually, they could have started paying closer attention to OCI and started incorporating it into their valuation models. Thirdly, following Ohlson's (1999) theory of transitory earnings, even if components of OCI are valuation irrelevant, they do impact firm value on a dollar-per-dollar basis. The magnitude of the OCI adjustments could have been growing over time, and this could have resulted in the significant associations with stock price and returns.

\subsubsection{Studies in the Canadian context}

Kanagaretnam, Mathieu and Shehata (2009) is the only study I am aware of that studied the usefulness of comprehensive income reporting in the Canadian context. They used as-reported ${ }^{17}$

\footnotetext{
${ }^{17}$ Kanagaretnam et al.(2009) use the numbers as-reported by the firms in their financial statements to compute the values for OCI as per the (then) proposed Canadian Handbook Section 1530. They collected the information on fair value disclosures from notes to financial statements. They exclude the change in additional minimum pension liability in excess of unrecognized prior service costs because this is not part of the Canadian standard. To the extent that this information is incrementally value relevant Kanagaretnam et al.'s (2009) study may have an omitted correlated variable bias.
} 
numbers for OCI and its components for a sample of Canadian firms cross-listed in the United States, which were required to report comprehensive income in accordance with SFAS 130 and $133^{18}$. Kanagaretnam et al. (2009) studied the usefulness of comprehensive income using data on seventy-five Canadian firms listed on the Toronto Stock Exchange and also traded on the New York Stock Exchange in the U.S. Cross-listed firms are required to reconcile the difference between Canadian and U.S. GAAP in the notes to their financial statements.

Kanagaretnam et al. (2009) ran two sets of regressions: (i) stock price on book-value, net income and individual OCI components, and (ii) stock returns on net income and individual OCI components. Individual OCI components tested by them include the change in (a) fair value of cash flow hedges (HEDGE); (b) fair value of available-for-sale investments (SEC); and (c) cumulative foreign currency translation adjustment (FOREX). All predictor variables were deflated by the number of outstanding shares. The choice of the deflator is not discussed, but it seems that they used the number of shares at the end of the period as the deflator.

Kanagaretnam et al. (2009) reported that for the Canadian firms, comprehensive income is more strongly associated with stock price (adjusted r-squared of 69.83 percent versus 66.69 percent for net income) and returns (adjusted r-squared of 5.25 percent versus 3.26 percent for net income) than is net income, and that two of its components, HEDGE and SEC, are also associated with stock price and stock returns (at a $\mathrm{p}<.05$ level). Interestingly, when they compared their basic, contemporaneous model with an expanded model that incorporates lagged values of the components of OCI as additional predictors for the association test for market returns, Kanagaretnam et al. (2009) reported an increase in adjusted r-squared from 12.4 percent to 16.2 percent, although none of the lagged variables turn out to be statistically significant. They also used dummy variables for losing and winning hedge positions, but only found statistical significance for the losing hedge position. They concluded that possibly such a partition only adds noise to net income, or, it could be that the markets view hedged positions in general as a positive signal of well-managed risk.

\footnotetext{
${ }^{18}$ SFAS 133, Accounting for Derivative Instruments and Hedging Activities, requires adjustments on derivative securities that qualify for cash flow or foreign currency hedge accounting treatment to be shown as part of other comprehensive income.
} 


\subsection{Studies examining analysts' earnings forecasts}

Choi and Zang (2006) is the only study that I am aware of which empirically examines the association between OCI and analysts' earnings forecasts. Using U.S. data, Choi and Zang (2006) found comprehensive income to be significantly associated with analysts' earnings forecast revisions and forecast errors. They documented an asymmetric use of comprehensive income by analysts and found that analysts tend to revise their following year's forecast downward when CI is lower than NI, but do not revise the forecast upward when CI is greater than NI. Choi and Zang (2006) attributed this finding to the greater possibility of future recognition of unrealized losses (which result in CI being less than $\mathrm{NI}$ ) than the future recognition of unrealized gains (which cause CI to be greater than $\mathrm{NI}$ ), which is in keeping with accounting conservatism.

In the following subsections, I briefly review the important findings of studies of analyst forecasts and forecast accuracy. Excellent summaries are provided by Kothari (2001) and Ramnath, Rock and Shane (Ramnath et al. 2008) for the extant literature which studies analysts' forecasts. These studies usually focus on the decision processes followed by analysts, the nature of analyst expertise and the distributional characteristics of their earnings forecasts, the information content of analyst research, the implication of analysts' forecast efficiency for securities market efficiency, analysts' incentives and behavioral biases, the impact of changes in the regulatory environment, and methodological issues (Ramnath et al. 2008).

\subsubsection{Importance of analysts' forecasts}

Analysts provide stock recommendations (i.e. buy-hold-sell) and produce reports to support these recommendations. Given this job-description, analysts may be expected to collect information, including accounting information for use in valuation and forecasting models. Under semi-strong market efficiency, the models that produce more accurate earnings forecasts could also be considered good proxies of market expectations (Brown 1993). It has been suggested that analysts' earnings forecasts convey information about firm value beyond what is implied by current earnings, book values and dividends (Sougiannis and Yaekura 2001). 
Ou and Sepe (2002) found that the value relevance of current earnings correlates negatively with the extent to which consensus analysts' forecasts deviate from current earnings. This implies that the extent to which analysts are able to accurately forecast earnings and the degree of consensus that exists amongst analysts with respect to these forecasts are associated with the value relevance of current earnings. This raises the question of what information and which valuation and forecasting techniques are used by analysts in making their forecasts.

\subsubsection{Information used by analysts in their earnings and valuation forecasts}

Analysts are believed to heavily use earnings-related information disaggregated into nonGAAP segments, and focus on core earnings as a basis for their forecasts of future earnings (Previts et al. 1994). It is also suggested that in being selective in their choice of which nonrecurring items contained in GAAP earnings to include in their valuation models, analysts demonstrate expertise in processing earnings information ( $\mathrm{Gu}$ and Chen 2004). Analysts also incorporate other information such as sales forecasts and management-provided forward looking information in their analyses (Bouwman et al. 1995; Keung 2010), although information processing limitations or limited time could inhibit analysts' use of more complex information (Plumlee 2003).

Analysts have been found to rely less on present value techniques such as Ohlson's residual income valuation model, and more on simple heuristics such as price-earnings-growth [PEG] multiples (Block 1999; Demirakos et al. 2004; Bryan and Tiras 2007), to convert analysts’ earnings forecasts into price targets and recommendations (Bradshaw 2004). An implication of the lower level of usage of valuation models by analysts is that analysts could be making little or no use of the accounting information about other comprehensive income. If this were the case, there should be no significant association between OCI numbers and analysts’ earnings forecasts.

Hirst and Hopkins (1998) investigated whether clear reporting of comprehensive income and its components facilitates detection of earnings management by buy-side financial analysts and predictably affects their stock price judgments. They used a 3x2 between-subjects experimental design on 96 buy-side security analysts and portfolio managers with an average of 14 years' financial analysis experience. The experiment included disclosure of the information in three 
formats, (1) pre-SFAS 130 format with comprehensive income not explicitly reported (No-CI), (2) Reporting comprehensive income in a statement of changes of equity (CI-SCE), and (3) separate reporting of comprehensive income in a statement accompanying the income statement (CI-IS). The earnings management involved the selling of a marketable security, recognizing the gain and then repurchasing the said security. Thus, in all cases - with earnings management (EM) and without earnings management (NEM), the comprehensive income was the same. Accumulated Other Comprehensive Income (AOCI) was also included in the Balance Sheet in all six cases. Hirst and Hopkins (1998) found that clear display of comprehensive income as CIIS made earnings management more transparent and resulted in statistically equal stock price judgments for the EM and NEM conditions. They also suggest that "fundamental variation in the way accounting information is reported in financial statements can have a predictable impact on analysts' stock price estimates”, and that “CI SCE reporting is not as effective in reporting valuerelevant information as the originally proposed CI IS reporting”.

It should be noted that since OCI is not included in the calculation of the earnings per share (EPS) number, we should expect to find little to no significant association between analysts’ forecasts of earnings and OCI. However, given that OCI components represent unrealized gains and losses, analysts could be making assumptions about their eventual (early) realization, and hence, we could find some significant association between analysts' forecasts and OCI numbers. If so, the OCI numbers could be contributory to the error in the analysts' forecasts relative to the actual EPS numbers.

\subsubsection{Analyst forecast accuracy and potential reasons for forecast error}

Analysts are believed to generally under-react to information, but over-react to positive information or good news (Chopra 1998; Easterwood and Nutt 1999; Karamanou 2000; Kantsyrev 2007). This results in forecast errors which tend to be significantly optimistic for buy recommendations and significantly pessimistic for sell recommendations (Eames et al. 2002).The accuracy of analysts’ forecasts depends on several factors, including the number of stocks normally followed (Hirst et al. 2004), the quality of corporate disclosures (Lang and Lundholm 1996; Botosan and Harris 2000; Dhaliwal et al. 2011; Hsu and Chiao 2011; Hope 2003) and 
corporate governance (Bhat et al. 2006), analysts’ education and experience (Clement 1999; Bernard 2008), audit quality (Behn et al. 2008; Payne 2008), information complexity and readability (Hodder et al. 2008; Lehavy et al. 2011), and the political connectedness of the firms followed (Chen et al. 2010).

Gu and Wu (2003) pointed out that earnings skewness is significantly related to analysts' forecast bias (or error). Analysts’ efforts to improve forecast accuracy could, in fact, be contributing to the observed forecast bias. Other factors that have been found to be related to analysts' forecast error include firm size, the number of analysts following a company, dispersion in analysts' forecasts, trading volume, expected future return on equity (Bradshaw 2000; Fan et al. 2006; Gu and Wu 2003; Han and Manry 2000; Beyer and Guttman 2011).

Ahmed et al (2005) found that analysts do not distinguish between discretionary and nondiscretionary accruals. Qiang (2005) found that although analysts' forecasts summarize 45-83 per cent of the information from a set of 22 information items, proxies for accounting conservatism and transitory earnings are incrementally useful in predicting future earnings. To the extent that OCI items are transitory, and are regarded by analysts to be transitory, there should be no significant association between OCI information and analysts' earnings forecasts. If OCI items are transitory, but are regarded by analysts to be persistent, they would be found to be significantly associated with analysts' earnings forecasts but contributing to significant forecast error. Lastly, if OCI items are, and are regarded by analysts as, persistent, they should be both significantly associated with analysts' forecasts and contributory to greater forecast accuracy.

Barth and Hutton (2004) examined whether analysts’ earnings forecast revisions reflect information about the persistence of earnings incremental to that contained in accruals, and whether this information is reflected in stock prices. They found that analysts' forecast revisions are positively and significantly associated with future changes in accruals as well as changes in earnings, after controlling for current year accruals. They also found that firms with consistent accrual and forecast revisions have significantly less persistent earnings, but they were unable to say whether analysts were able to identify firms with low accrual persistence. 
Recent psychological-experimental studies have documented the inability of users of financial accounting information to correctly process information pertaining to fair value gains and losses, especially when these arise from changes in credit risk (Gaynor et al. 2011), or where these fair value changes are contingent on whether the financial instrument is an asset or liability, whether such fair value changes give rise to gains or losses, and whether the underlying item would be sold or settled soon (Koonce et al. 2011). Given that OCI is generally considered to be transitory, it would be interesting to test for the association of OCI and its components with analysts' earnings forecasts. As mentioned in the earlier section, it may be possible that OCI numbers could be significantly associated with analysts' forecast errors. This is because analysts could make erroneous assumptions regarding the timing of the realization of the unrealized gains and losses represented by OCI.

\subsection{Implications of, and Conclusions from existing studies: the gap in the literature and how the present study fits in it}

Over the years, there has been an increase in the amount of evidence indicating that OCI and at least some of its components are associated with stock value and stock returns (Chambers et al. 2007; Choi et al. 2007; Kanagaretnam et al. 2009). OCI items have also been found to be associated with analysts’ earnings forecasts, with negative OCI values leading to more pronounced downward revisions by analysts. OCI has been shown to display negative persistence, that is they tend to partially reverse over time (Jones and Smith 2011). Whereas persistence in general is viewed as proof that an earnings item is not transitory, the atrophy indicated by the negative persistence could be viewed as proof that OCI items are transitory but that their value reversals take multiple periods of time, perhaps because managers exercise discretion in timing the realization of unrealized gains and losses (Choi and Zang 2006).

There remains the question whether the items currently designated as components of OCI should be aggregated as such, or if they merit separate disclosure based on their individual persistence, predictive ability and value relevance. Theory suggests that the components of other comprehensive income are transitory, and hence likely to be of no predictive value. However, it does not mean that OCI does not affect firm value at all. Ohlson (1999) predicted that OCI would 
affect firm value on a dollar-per-dollar basis, i.e. every dollar of OCI would cause an equivalent amount of change in firm value. In other words, the coefficient on a regression of stock price on per-share OCI would be one. However, Chambers et al (2007) found that whereas the coefficients on three components of $\mathrm{OCI}_{130}$, namely the foreign currency translation adjustment (FCADJ), the pension adjustment (PENADJ) and the sum of unrealized gains and losses from derivatives and other residual adjustments reported by firms under SFAS 130 (OTHER) were all insignificantly different from one, the coefficient on the adjustment for marketable securities (MKTADJ) was not only significantly different from one, it was also larger than the coefficient on net income. In their discussion of this puzzling result, Chambers et al (2007) refer to Bloomfield, Nelson and Smith's (2006) theory in which they suggested that investors might fail to recognize the redundancy of unrealized gains and losses that are correlated with past firm returns. If the correlated investment is large, and the correlated unrealized gains and losses are made salient by comprehensive income reporting, the prices and earnings would become highly volatile. This line of thinking indicates market mispricing as a potential reason for the seemingly higher persistence of the MKTADJ variable. Chambers et al (2007) leave this issue open to future research. While not directly addressing the reasons, in this study I test whether Chambers et al's (2007) findings hold in the Canadian context.

There is an apparent gap in the literature with regards to studying the decision-usefulness of comprehensive income using actually reported Canadian data, especially given the reluctance on part of the AcSB in adopting the concept of comprehensive income in Canada. Kanagaretnam et al.'s (2009) study can be extended in a number of ways. First, the sample used by Kanagaretnam et al. (2009) is limited to the years 1998-2003, i.e. a time period prior to the coming into effect of HB1530 in Canada. In this study, I use actually reported data for the time period during which HB1530 was in effect. Secondly, Kanagaretnam et al (2009) do not examine the possibility that the OCI component not included under HB1530 - minimum pension adjustment (PENADJ) might yet be value relevant.

Finally, other than Choi and Zang (2006), the issue of the association between OCI and analysts' earnings forecasts has not been examined in the literature. Analysts are generally regarded to proxy for capital markets (Fried and Givoly 1982; Ofer and Siegel 1987). Also, sell- 
side analysts act as important source of investment advice for retail, unsophisticated users (Mikhail et al. 2007; Bonner et al. 2003). In this study, I test for the association between analysts' earnings forecasts and aggregate OCI, as well as its components. I also test whether OCI and its components are associated with analysts' forecast errors. 


\section{Chapter Four: Theoretical Framework}

\subsection{Decision Usefulness}

Accounting information may be said to have decision usefulness if it is used by financial statements users for decision making. The two primary qualities that make accounting information useful for decision making are relevance and reliability (Schroeder and Clark 1995; Kieso et al. 2007) ${ }^{19}$. Reliability relates to verifiability, representational faithfulness and neutrality, and is usually considered to be achieved if the information is backed by independent assurance. However, since audited financial statements take time to be released ${ }^{20}$, it is argued that the delayed release of the information reduces its relevance. Relevance refers to the ability of information to influence a decision, and such information must meet the criteria of predictive value, feedback value and timeliness ${ }^{21}$.

Accounting information is considered to be decision-useful if it (i) has information content, i.e. it elicits a reaction in the form of stock price changes (returns) and/or increased trading activity (Beaver, 1968); (ii) is valuation-relevant, i.e. is significantly associated with stock price (returns) relative to or incremental to other competing information, given prior expectations (Ball and Brown, 1968); or (iii) is value-relevant, i.e. it is associated with stock price (returns). As Lo and Lys (2000) explained, the major difference between valuation-relevance and value-relevance is that whereas the former requires a specification of prior expectations, the latter precludes the need for any predicted relationship.

Research examining the timeliness of accounting numbers is usually called the information content literature, which examines the association between announcement of earnings and stockmarket return or trading volume (Beaver 1968; Ball and Brown 1968; Beaver et al. 1997). If a

\footnotetext{
${ }^{19}$ The conceptual framework under IFRS views Relevance (Predictive Value, Confirmatory Value and Materiality) and Faithful Representation (Completeness, Neutrality and Freedom from Error) as the two fundamental qualitative characteristics of useful accounting information. This change was effected to address the problem of trading-off Relevance (which formerly included the additional attribute of Timeliness) and Reliability (which required Verifiability as an attribute in addition to Faithful Representation).

${ }^{20}$ It is common for audited financial statements to be released up to 3 or 4 months after the fiscal year end.

${ }^{21}$ Part II of the Accounting Handbook retains the original descriptions of Relevance and Reliability as the primary qualitative characteristics.
} 
statistically significant change is observed in either the stock price or trading volume in the period around the announcement, then such announcement is considered to have information content, i.e. timeliness. Research examining the value relevance of accounting numbers typically draws upon the residual income valuation approach suggested by Ohlson (1995) and Feltham and Ohlson (1995) to examine the relative or incremental associations of certain accounting data with stock-price (Barth et al. 2001a; Holthausen and Watts 2001; Aboody et al. 1999; Barth et al. 1992). In this case, a statistically significant coefficient on the variable of interest in regression analyses is considered to indicate value relevance.

In the case of comprehensive income, relative value-relevance studies compare the rsquareds for regressions of stock price (returns) on operating income / net income and comprehensive income. Studies of incremental value-relevance examine the coefficient on items of OCI in multivariate regressions of stock price (returns) on net income and the OCI items.

Relative value relevance studies compare the coefficients and the r-squareds of regressions using competing predictors (e.g. Net Income and Comprehensive Income in Dhaliwal et al. 1999), while incremental value relevance studies include both competing predictors in the same model and test the coefficients for significance (e.g. Chambers et al. 2007). Van Cauwenberge (2007) provides a detailed discussion on the nature and specification of value relevance tests. This research is situated within the broader domain of capital markets research in accounting, for which there are excellent summaries available in the literature (Lev and Ohlson 1982; Kothari 2001).

\subsection{Market efficiency}

The efficient markets hypothesis (EMH) builds on the notion of informational and suggests that capital markets impound all available information in the prices of traded assets, such that it is impossible to outperform the market using an information-based trading strategy. However, markets may be efficient to varying degrees - strong, semi-strong and weak (Fama 1991, 1970). Strong form market efficiency hypothesis suggests that current stock prices incorporate all information relevant to the firm, both public and private. The weak-form efficiency hypothesis suggests that stock prices reflect all information that can be derived from market trading data, 
such as past prices, trading volume or short interest (Bodie et al. 2003). It is usual in accounting research to assume semi-strong market efficiency, which suggests that all publicly available information regarding the firm's prospects is already reflected in the stock price.

Market efficiency is a broad notion, and implies informational (transparency and disclosure of information required to make an investment decision) efficiency, transactional (operational) and allocational (investors adjust the rate of return to ensure the present value of the marginal project equals zero) efficiency (Hendry and King 2004). This assumption is vital to any capital markets based study, since capital markets research uses stock price or stock returns as the dependent variable, and accounting information as part of the exogenous variable set.

In this study I employ the value-relevance approach to examine both the relative and the incremental (to net income) value-relevance of comprehensive income and other comprehensive income. Since I use stock prices and returns as dependent variables, I assume semi-strong securities market efficiency. In the absence of a viable alternative, this is a necessary assumption (Malkiel 2005; Malkiel and Fama 1970), although a valid charge can be leveled against it that such an assumption renders any capital markets study a test of joint hypotheses - the ones under examination and the efficient markets hypothesis. Ironically, there is a considerable body of literature which provides evidence that questions market efficiency, including the post-earnings announcement drift (Ball and Brown 1968), the accruals anomaly (Sloan 1996) as well as studies from behavioural finance (Shleifer 2000; Shiller 2003; Subrahmanyam 2007).

\subsection{Ohlson's Residual Income Valuation model}

I use the theoretical model proposed by Ohlson (1999) to examine the question of value relevance of comprehensive reporting in Canada. According to Ohlson (1999), a firm's earnings may be decomposed into "core” earnings and "transitory” earnings. Core earnings refer to those components of earnings that display persistence over time. Core earnings are usually proxied for by earnings before non-recurring items (Collins et al. 1997), although the term could well be defined in many other ways (Bricker et al. 1995). Applying Ohlson’s (1999) definition of predictability, forecasting-relevance and valuation-relevance, earnings are transitory if they are unpredictable (i.e. future earnings cannot be predicted using current period numbers), forecasting 
irrelevant (current period numbers are not helpful in predicting future performance), and valuation-irrelevant (current period numbers do not affect future changes in value). Using Ohlson's (1999) notations, $x_{t}=x_{1 t}+x_{2 t}=$ total earnings in period t, where, $x_{1 t}=$ core earnings in period $t$ and $x_{2 t}=$ transitory earnings in period t. Ohlson (1999) assumes:

(i) Present Value Relation (PVR) $P_{t}=b_{t}+\sum_{\tau=1}^{\infty} R^{-\tau} E_{t}\left[\tilde{d}_{t+\tau}\right]$ holds, i.e. stock price equals pershare book-value of assets plus the present value of expected future dividends, where

$$
\begin{aligned}
& P_{t}=\text { market value at date } t \\
& b_{t}=\text { book value at date } t \\
& R=1+\text { cost-of-equity capital, } \\
& E_{t}[] \text { is the expected value function for period } t \text { and } \\
& \tilde{d}_{t+\tau} \text { refers to expected future dividends. }
\end{aligned}
$$

(ii) The Clean Surplus Relation (CSR) (Feltham and Ohlson 1995; Ohlson 1999) holds. Clean surplus accounting obtains when $x_{t}=b_{t}+d_{t}-b_{t-1}$, where the partial derivatives are $\partial b_{t} / \partial d_{t}=-1$ and $\partial x_{t} / \partial d_{t}=0$, and the subscripts denote the time period. This definition of earnings, $x_{t}$, is conceptually similar to the one intended by the FASB (and the AcSB) for comprehensive income, in that it includes net income along with any 'dirty surplus' items that have bypassed the income statement (Ohlson, (1999); p148)

(iii) and that the forecasting error terms, although they may be correlated, are unpredictable with zero means,

Considering the three assumptions above, Ohlson (1999) obtains the following residual income valuation (RIV) formula:

$$
P_{t}=b_{t}+\sum_{\tau=1}^{\infty} R^{-\tau} E_{t}\left[\tilde{x}_{t+\tau}^{a}\right]
$$

where the definitions of $P_{t}, b_{t}, R$ and $E_{t}$ are as above, and 
$x_{t}^{a} \equiv x_{t}-r b_{t-1}=$ abnormal earnings in period $t$.

This RIV formula holds provided the dividend policy is such that $R^{-\tau} E_{t}\left[\tilde{b}_{t+\tau}\right] \rightarrow 0$ as $\tau \rightarrow$ $\infty$, i.e. in the long run, the assets of the firm would be liquidated and distributed among the shareholders.

Ohlson's (1999) third assumption specifies the forecasting of the sequence of expected abnormal earnings in terms of the current information. Specifically, it is assumed:

$\tilde{x}_{t+1}^{a}=\omega_{11} x_{t}^{a}+\omega_{12} x_{2 t}+\tilde{\varepsilon}_{1 t+1}$ and,

$\tilde{x}_{2 t+1}=\omega_{21} x_{t}^{a}+\omega_{22} x_{2 t}+\tilde{\varepsilon}_{2 t+1}$, where $\omega_{i j}$ are regression coefficients, $\tilde{x}_{t+1}^{a}$ is forecast abnormal earnings for period $t+1, x_{t}^{a}$ is abnormal earnings in period $t$, and $x_{2 t}$ is the transitory earnings in period $t . \varepsilon$ 's are the forecast-errors for the two equations. Ohlson (1999) notes that (p 148)

(i) $\omega_{22}$ should be equal to zero. This indicates unpredictability or non-persistence of transitory earnings. However, Ohlson (1999) does consider the possibility that $0<\omega_{22}<1$, which would suggest that while transitory earnings are serially correlated, their long run average equals zero.

(ii) $\omega_{21}=0$, suggesting that core earnings and book values do not influence the evolution of transitory earnings. $\omega_{21}$ ought to be zero if $x_{2 t}$ is transitory earnings, i.e. current period's abnormal earnings do not predict the next period's OCI. This too implies unpredictability.

(iii) Because $x_{t}^{a}$ includes transitory earnings, it is expected that $\omega_{11}+\omega_{12}=0$, implying that $x_{1 t}^{a} \equiv x_{1 t}-r b_{t-1}$, i.e. current core earnings summarize all relevant information to forecast next-period expected abnormal earnings. This is referred to as forecastingirrelevance of transitory earnings. This means that transitory earnings have a similar effect on next period's expected earnings as do dividends. That is, even if $\omega_{11}+\omega_{12} \neq$ 
0 , the partial derivatives $\partial b_{t} / \partial d_{t}=-1$ and $\partial b_{t} / \partial x_{2 t}=1$, imply that transitory earnings contribute to book value on a dollar-for-dollar basis.

(iv) $\omega_{11}+\omega_{12}=0$ also implies because transitory earnings are "passed-on" as dividends, they would have no effect on next-period expected earnings (p 150). Applying the RIV formula, we get $P_{t}=b_{t}+\alpha_{1} x_{t}^{a}+\alpha_{2} x_{2 t}$, where $\alpha$ 's are coefficients. Ohlson (1999) suggests that transitory earnings are value-irrelevant, i.e. $\alpha_{1}+\alpha_{2}=0$, which implies that the partial derivative is $\partial P_{t} / \partial x_{2 t}=1$.

In summary, Ohlson (1999) formalized three attributes of transitory earnings, (i) unpredictability ( $\left.\omega_{22}=0\right)$; (ii) forecasting-irrelevance ( $\left.\omega_{11}+\omega_{12}=0\right)$; and (iii) value-irrelevance $\left(\alpha_{1}+\alpha_{2}=0\right)$. Thus, the RIV formula precludes any role for transitory earnings, in that being unpredictable, and therefore not persistent, transitory earnings would not have any abnormal component. However, Ohlson (1999) cautioned against making such an inference. Although transitory earnings items "are of no informational relevance in forecasting and valuation, ... it is not implied that the underlying transaction is irrelevant” ( $\mathrm{p}$ 146-147). Consistent with prior residual earnings valuation models (Feltham and Ohlson 1995; Ohlson 1995), Ohlson (1999) demonstrated that whereas core earnings, being further decomposed into expected and abnormal components is expected to affect value at a rate greater than dollar for dollar, transitory earnings are unpredictable, forecast irrelevant and value irrelevant. Nevertheless, "their informational significance is fully picked up by end-of-period book values” ( $\mathrm{p}$ 151), and as demonstrated by Chambers et al. (2007), transitory earnings should affect firm value dollar-for-dollar.

\subsubsection{Empirical evidence}

Barth, Beaver, Hand and Landsman (1999) were possibly the first to use the framework of Ohlson (1999) to study the value relevance of accrual and cash flow components of earnings. Barth et al (1999) specifically tested (i) the ability of accruals and cash flow components of earnings to forecast future abnormal earnings, (ii) whether accrual and cash flow components of earnings have incremental explanatory power in a valuation model that includes book value and abnormal earnings, and (iii) whether valuation multiples on accruals and cash flows vary based 
on persistence of the components of earnings? In order to estimate abnormal earnings, Barth et al (1999) used a 12 per cent rate to estimate expected earnings (beginning book value of equity time 12\%), with abnormal earnings being equal to net income less expected earnings. Barth et al found that accruals and cash flows have significant explanatory power in forecasting future abnormal earnings, as well as for valuation. They concluded that their reported findings were consistent with Ohlson (1999) and that accruals and cash flow components of earnings are persistent.

What about transitory earnings? Ohlson (1999) had likened OCI to special items (pp 159160). The incidence of special items reported in the income statement has increased (Johnson et al. 2011), with some "non-recurring” items showing a greater propensity to "recur" so often that the market has begun valuing them more like other components of recurring earnings (Cready et al. 2010). Jones and Smith (2011) compared the Value Relevance, Predictive Value, and Persistence of OCI and Special Items (SI). They found that contrary to the predictions of Ohlson (1999), both special items and other comprehensive income display the characteristics of value relevance and predictive value. Further, whereas SI have zero persistence, OCI items display negative persistence, that is, they tend to partially reverse over time. It should be noted that Jones and Smith (2011) do not employ Ohlson’s (1999) linear information dynamics approach, and thus, it possible that their tests' specification caused their results to be different from Ohlson's (1999) predictions. In this study, I provide additional evidence on OCI's persistence, forecasting relevance and value relevance by following the specifications in Ohlson (1999). 


\section{Chapter Five: Research Design and Methodology}

In this study I am interested in determining the decision usefulness of comprehensive income. Comprehensive income consists of net income plus other comprehensive income. Under HB1530, components of other comprehensive income include:

(1) changes in gains and losses on derivatives designated as cash flow hedges (HEDGE)

(2) changes in fair value of available for sale investments, net of reclassification adjustments $^{22}$ (SEC)

(3) unrealized foreign currency translation gains and losses, net of hedging activities (FOREX)

I refer to the three components listed above as HEDGE, SEC and FOREX, and their sum as $\mathrm{OCI}_{1530}$. I refer to OCI under SFAS 130 as $\mathrm{OCI}_{130}$, which includes the three components of $\mathrm{OCI}_{1530}$ and an additional item:

(4) minimum required pension liability adjustments (PENADJ).

For examining value relevance I test the association between OCI or its components and the following dependent variables:

a. Price $\left(P / S_{i t}\right)$ : The market price per share of firm i's equity three months after the end of the fiscal year $t$.

b. Return $\left(R E T_{i t}\right)=P / S_{i, t}-P / S_{i, t-1}+d_{i t}$. The buy-and-hold raw return, calculated as the change in price per share $\left(P / S_{i, t}-P / S_{i, t-1}\right)$, plus the dividend per share $\left(d_{i t}\right)$ for the year ended three months after the end of the fiscal year $t$ (i.e. for the window nine months before to three months after the fiscal year-end). Under the Continuous Disclosure requirements of the Ontario Securities Commission, firms listed on the Toronto Stock Exchange must file their annual reports within 90 days of their fiscal year-end (Ontario Securities Commission). It is assumed that the stock purchase is made at the time of the annual earnings announcement, by

\footnotetext{
${ }^{22}$ Once a gain or loss which was earlier accounted for in comprehensive income is recognized, it may be reclassified from accumulated other comprehensive income to net income. Any adjustment required at the time of reclassification is to be recorded to OCI
} 
which time much of the information contained in the earnings number would have been impounded in the stock price. The holding period is until the next earnings announcement, and again, it is assumed that the stock price reflects the new information contained in the next period earnings.

In this study I do not attempt to address the question of whether comprehensive income information is timely. I only seek to provide some empirical evidence on how well comprehensive income reflects or summarizes "the economic condition of the firm, as reflected by its stock price” (Van Cauwenberge 2007).

Table 5.1 reproduces the illustration provided in the CICA Accounting Handbook section 1530, Comprehensive Income ${ }^{23}$. It would be noticed from the example that, for the most part, the gains and losses recorded under OCI do end up in net income upon realization. Hence, these items would be expected to have a long-term mean of zero as suggested in Dee (1999). This also implies that the components of OCI are transitory, as there are no plausible reasons to expect a permanent mismatch between the amounts recorded under OCI and their final recognition to net income ${ }^{24}$.

\footnotetext{
${ }^{23}$ This table is also included on page xiv. It is reproduced here for ease of reference.

${ }^{24}$ For a detailed discussion and example of the accounting treatment of one of the components of OCI, namely available for sale investments, see Kieso et al. (2007, pp 523-534). Please note that later editions of the text are based on IFRS, and may not be directly comparable.
} 
Table 5-1: Illustrative example of a statement of comprehensive income

\section{Statement of Comprehensive Income}

For the year ended December 31 (\$ thousands)

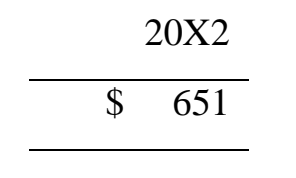

547

Unrealized gains and losses on translating financial statements of self-sustaining foreign operations (a)

Gains and losses on hedges of unrealized foreign currency translation losses and gains

Unrealized foreign currency translation gains and losses, net of hedging activities

Unrealized gains and losses on available-for-sale financial assets arising during the period

Reclassification adjustment for gains and losses included in net income

Change in unrealized gains and losses on available-for-sale financial assets

Gains and losses on derivatives designated as cash flow hedges

Gains and losses on derivatives designated as cash flow hedges in prior periods transferred to net income in the current period

Change in gains and losses on derivatives designated as cash flow hedges

Other comprehensive income

Comprehensive income
(545)

2

1,689

277

62

\begin{tabular}{|c|c|c|}
\hline & 1,689 & 277 \\
\hline & (317) & 62 \\
\hline & 1,372 & 339 \\
\hline & 1,723 & 687 \\
\hline & (995) & (333) \\
\hline & 728 & 354 \\
\hline & 2,102 & 702 \\
\hline$\$$ & 2,753 & \$ 724 \\
\hline
\end{tabular}

20X1

$\$ 22$

627

(618)

9

(a) It is assumed that there was no reduction in the net investment in a foreign operation. Therefore, there is no reclassification adjustment.

source: Reproduced from CICA Accounting Handbook section 1530 Comprehensive Income, paragraph 12.

If OCI items are transitory, Ohlson's (1999) predictions should apply. None of the components of OCI should be value relevant, i.e. their coefficients from regressing stock price (or total MVE) on components of comprehensive income should be insignificant. Also, the components should be forecast irrelevant, i.e. the coefficients from regressing future period stock 
price (or current stock price on lagged components) should also be statistically insignificant. However, as Ohlson (1999) reminds us, the components of OCI would impact firm value on a dollar-for-dollar basis, similar to the effect of dividends. Whereas items of OCI might revert over time, if the unrealized gains and losses are indeed realized (say an available for sale security with OCI losses is sold at a loss) the loss is reported in the income statement through a reclassification adjustment. The markets could anticipate that reclassification and impound this information about future earnings. This could cause OCI values being associated with stock price or stock return, indicating value relevance.

Alternatively, from a functional fixation perspective, it may be argued that in the early years following the implementation of SFAS 130 in the U.S., financial statement users did not consider information on OCI. This may well have been due to processing limitations imposed by the decision of the majority of firms to report OCI as part of the statement of changes in equity, instead of a more prominent display in a statement of comprehensive income. However, with the passage of time, market participants could have started using the OCI information in their valuation decisions, thus attributing value relevance to OCI.

\subsection{Testing Ohlson's Residual Income Valuation model for transitory earnings}

One of Skinner's (1999) major criticisms of Dhaliwal et al.’s (1999) study of the valuerelevance of comprehensive income was that the tests were not informed by any economic theory. In this study I address this concern by using Ohlson's (1999) work on the relevance of transitory earnings. However, before proceeding, I would like to test whether the predictions of the model are satisfied empirically. Specifically, Ohlson (1999) predicts that transitory earnings reflect the following characteristics: (i) unpredictability (ii) forecasting-irrelevance and (iii) value-irrelevance.

Ohlson (1999) also specifies the following:

$$
\begin{aligned}
& \tilde{x}_{t+1}^{a}=\omega_{11} x_{t}^{a}+\omega_{12} x_{2 t}+\tilde{\varepsilon}_{1 t+1} \text { and, } \\
& \tilde{x}_{2 t+1}=\omega_{21} x_{t}^{a}+\omega_{22} x_{2 t}+\tilde{\varepsilon}_{2 t+1},
\end{aligned}
$$


where $\omega_{i j}$ are regression coefficients, $\tilde{x}_{t+1}^{a}$ is forecast abnormal earnings for period $t+1$, $x_{t}^{a}$ is abnormal earnings in period $t$, and $x_{2 t}$ is the transitory earnings in period $t$. $\varepsilon$ 's are the forecasterrors for the two equations.

The preceding equations require specification of what comprises abnormal earnings. Abnormal earnings may be specified in several different ways. For example, one option would be to estimate the cost of equity capital for each firm using its $\beta$ (beta), using the market model $\mathrm{R}_{\mathrm{j}, \mathrm{t}}=\alpha_{\mathrm{t}}+\beta^{*} \mathrm{R}_{\mathrm{m}, \mathrm{t}}+\varepsilon_{\mathrm{t}}$,

where $R_{j, t}$ is the return on security j over time $t$,

$\alpha_{t}$ is the intercept term equal to $R_{f, t} *(1-\beta)$, where $R_{f, t}$ is the risk free rate in time $t$, $\mathrm{R}_{\mathrm{m}, \mathrm{t}}$ is the market return over time $\mathrm{t}$, and

$\varepsilon_{\mathrm{t}}$ is the error term. The error term is viewed as the abnormal stock return, that is the excess of the stock return over the expected return $\left(\alpha_{t}+\beta^{*} R_{m, t}\right)$

There are, of course, other specifications possible for the stock beta (Brimble and Hodgson 2007). However empirical support for using market beta has yielded mixed results. Fama and French (1992) show that size, measured as the market value of equity, and leverage, measured as the book-value to market-value ratio, capture the variations in stock returns. They also show that size is highly correlated with stock beta, and can thus substitute for it. Fama and French (1992) also show that controlling for size, stock beta is only marginally associated with stock returns. One possible explanation for the poor results for beta is that it does not remain stationary, and that it changes over time (Chen 1981). It could be that over a long period of time, beta is associated with stock returns, as was shown by Kothari, Shanken and Sloan, (Kothari et al. 1995). However, using the market model to estimate the betas is prone to estimation error (Shanken 1992; Clarkson and Thompson 1990).

Another option may be to estimate a normal return $r_{\mathrm{m}}$ and specify $x_{t}^{a}=x_{t}-r_{m} b_{t-1}$, i.e. abnormal earnings $x_{t}^{a}$ equals actual earnings $x_{t}$ minus expected earnings, which is equal to the normal return, $r_{m}$, times the beginning of period $b_{t-1}$. We can specify an expected rate of return 
of 12 percent, such that $x_{t}^{a}=x_{t}-0.12 b_{t-1}$. The 12 percent rate is the average return on equity investments, and has been used in the literature (see, for example, Barth et al, 1999). The 12 per cent rate is also the average profitability rate reported by Industry Canada for Small and Medium Industries (Industry Canada 2010). According to a Statistics Canada publication, the return on equity, calculated as earnings before interest and taxes (EBIT) divided by Shareholders' Equity was around 30 per cent during the 2000 to 2009 period (Lafrance 2012). Assuming a debt-equity ratio of $1: 1$, interest cost of 10 per cent, and an average tax rate of 40 per cent, the ROE would be 15 per cent if calculated on after-tax earnings. It could be argued that 12 per cent is a slightly conservative estimate of ROE.

Even if it is conceded that using a 12 per cent normal rate to compute abnormal earnings provides for a crude proxy, this approach is a pragmatic alternative to the possibly more problematic issue of estimation error in calculating the expected rate of return for individual companies using market beta. The basic idea behind Ohlson's approach is that as long as a rate of return of capital employed is specified, the model should work. Nevertheless, as part of robustness checks, I re-estimated abnormal earnings using the annual TSX return, or 2-digit SIC industry level return as alternative specifications of expected return. It should be noted, though, that the TSX or industry returns are returns on stocks, and might not be good proxies for expected returns on capital employed. Yet another alternative could be to make a naive assumption that the previous year's net income is a proxy for the current year's expected income. Hence, any difference between the previous- and the current-year's net income could be considered abnormal earnings.

\subsubsection{Regressions to test OCI's ability to forecast future abnormal earnings}

Forecasting irrelevance is implied if the sum of the coefficients of the regression of current period abnormal earnings on prior year abnormal earnings $\left(\omega_{11}\right)$ and prior-year OCI $\left(\omega_{12}\right)$ is (statistically close to) zero. Note that abnormal earnings include items of OCI, so reintroducing OCI into the equation would appear as double counting, unless the regression coefficients adjust for this fact. However, if abnormal earnings are defined as excluding OCI items, the coefficients would be partial-coefficients. In this case, the sum of the two coefficients should be the 
coefficient of the regression of current-period abnormal earnings (including OCI) on prior-period abnormal earnings (including OCI). I estimate the following regressions:

$$
\begin{aligned}
& \text { AbnEarn } / S_{i t}=\alpha_{0}+\alpha_{1} \text { AbnEarn } / S_{i t-1}+\alpha_{2} O C I / S_{1530 ~ i t-1}+\varepsilon_{i t} \\
& \text { AbnEarn } / S_{i t}=\alpha_{0}+\alpha_{1} \text { AbnEarn } / S_{i t-1}+\alpha_{2} O C I / S_{130 ~ i t-1}+\varepsilon_{i t} \\
& \operatorname{AbnEarn} / S_{i t}=\alpha_{0}+\alpha_{1} A b n E a r n / S_{i t-1}+\alpha_{2} H E D G E / S_{i t-1}+\alpha_{3} S E C / S_{i t-1}+\alpha_{4} F O R E X / S_{i t-1}+\varepsilon_{i t}[1 \mathrm{c}] \\
& \text { AbnEarn } / S_{i t}=\alpha_{0}+\alpha_{1} \text { AbnEarn } / S_{i t-1}+\alpha_{2} \text { HEDGE } / S_{i t-1}+\alpha_{3} S E C / S_{i t-1}+\alpha_{4} \text { FOREX/S }{ }_{i t-1}+ \\
& \alpha_{5} \text { PENADJ/S } S_{i t-1}+\varepsilon_{i t}
\end{aligned}
$$

where subscripts $i$ and $t$ denote the firm $i$ and year $t$ respectively,

AbnEarn/S ${ }_{i t}$ the difference between the actual earnings per share and the expected earnings, specified as beginning book value per share multiplied by 12 per cent.

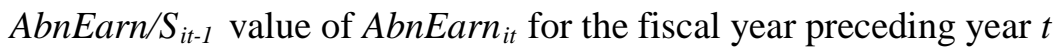

$H E D G E / S_{i t-1}$ the per share change in the fair value of cash flow hedges under Canadian GAAP the fiscal year $\mathrm{t}-1$;

$S E C / S_{i t-1}$ the per share change in the fair value of available-for-sale investments under Canadian GAAP for the fiscal year $t-1$; and

FOREX/S $S_{\text {it-1 }}$ the per share change in cumulative foreign currency translation adjustment under Canadian GAAP for the fiscal year $\mathrm{t}-1$.

$P E N A D J / S_{i t-1}$ the per share change in additional minimum pension liability in excess of unrecognized prior service costs under SFAS 130 for the fiscal year $\mathrm{t}-1$

$O C I_{1530} / S_{\text {,it-1 }}$ the sum of $H E D G E / S_{i t-1}$ (fair value changes in cash flow hedges), $S E C / S_{i t-1}$ (fair value changes in available for sale investments) and FOREX/S ${ }_{\text {it-1 }}$ (changes in cumulative foreign currency translation adjustment) following Canadian GAAP.

$O C I_{130} / S_{i t-1} \quad O C I_{1530} / S$ plus $P E N A D J / S_{i t-1}$ (pension adjustment on defined benefit pension plans, as required under SFAS 130 of U.S. GAAP.

According to Ohlson (1999), forecasting irrelevance is implied if the sum of the coefficients on abnormal earnings and on OCI in equation 1a are statistically equal to zero. To test for this, I 
compute a new variable AEDiffOCI, which is equal to the difference of Abnormal Earnings and $\mathrm{OCI}_{1530}{ }^{25}$. I then run the following model:

AbnEarn $/ S_{i t}=\alpha_{0}+\alpha_{1}$ AEDiffOCI ${ }_{i t-1}+\varepsilon_{i t}$

where

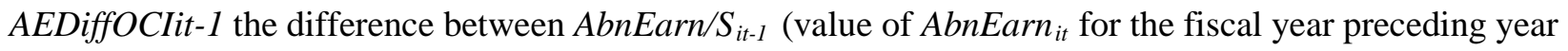
t) and $O C I_{1530} / S_{i t-1}$

With other variables as defined earlier

Equation 1e is a constrained model since by computing one coefficient for the difference of Abnormal Earnings and $\mathrm{OCI}_{1530} \mathrm{I}$ am forcing the estimated effects of their sum to be equal to zero. Equation 1a is the unconstrained model, where the effects of Abnormal Earnings and $\mathrm{OCI}_{1530}$ are not constrained to be equal to zero. I then conduct an incremental F test:

$F_{J, N-K-1}=\frac{\left(R_{U}^{2}-R_{C}^{2}\right) *(N-K-J)}{\left(1-R_{U}^{2}\right) * J}$, where $\mathrm{F}_{\mathrm{J}, \mathrm{N}-\mathrm{K}-1}$ is the F-statistic value with $\mathrm{J}$ constraints, $\mathrm{N}$

observations, and $\mathrm{K}$ independent variables in the unconstrained model. $R_{U}^{2}$ is the r-squared value for the unconstrained model and $R_{C}^{2}$ is the r-squared value for the constrained model. The significance of the F-statistic is given by the t-statistic obtained by the square-root of $\mathrm{F}$.

If the sum of the coefficients on abnormal earnings and OCI is indeed equal to zero, the tstatistic obtained from the above procedure should be statistically insignificant. If, on the other hand, the incremental F-test does prove to be significant, then we can conclude that the sum of the coefficients is not (statistically) equal to zero, and that OCI does indeed possess incremental forecasting relevance.

\subsubsection{Regressions to test predictability of OCI}

Testing for unpredictability requires regressing current-year OCI on prior-year abnormal earnings $\left(\omega_{21}\right)$ and prior-year OCI $\left(\omega_{22}\right)$. Ohlson's $(1999)$ prediction is that the coefficients

\footnotetext{
${ }^{25}$ I am indebted to Professor Richard Williams of the Notre Dame University for this approach, which I found to be particularly simple to apply. I accessed Professor Williams' teaching notes through an online search from www.nd.edu/ rwilliam/stats2/142.pdf
} 
would be (statistically close to) zero. He does note, however, that it is possible that there might be some serial correlation among the OCI items, i.e. $\omega_{22}$ may lie between 0 and 1 . However, if $\omega_{22}$ is negative, that is $\omega_{22}<0$, it would suggest that OCI displays negative persistence, and tends to partially reverse over time. Accordingly, I estimate the following regressions:

$$
\begin{aligned}
\text { OCI }_{1530} / S_{i t}= & \beta_{0}+\beta_{1} A b n E a r n / S_{i t-1}+\beta_{2} O C I_{1530} / S_{i t-1}+\varepsilon_{i t} \\
\text { OCI }_{1530} / S_{i t}= & \beta_{0}+\beta_{1} A b n E a r n / S_{i t-1}+\beta_{2} H E D G E / S_{i t-1}+\beta_{3} S E C / S_{i t-1}+\beta_{4} F O R E X / S_{i t-1}+\varepsilon_{i t}[2 \mathrm{~b}] \\
\text { OCI }_{130} / S_{i t}= & \beta_{0}+\beta_{1} A b n E a r n / S_{i t-1}+\beta_{2} O C I_{130} / S_{i t-1}+\varepsilon_{i t} \\
\text { OCI }_{130} / S_{i t}= & \beta_{0}+\beta_{1} A b n E a r n / S_{i t-1}+\beta_{2} H E D G E / S_{i t-1}+\beta_{3} S E C / S_{i t-1}+\beta_{4} F O R E X / S_{i t-1}+\beta_{5} P E N A D J / S_{i t-1} \\
& +\varepsilon_{i t}
\end{aligned}
$$

where subscripts $i$ and $t$ denote the firm $i$ and year $t$ respectively, and the variables are as defined earlier.

\subsection{Testing for the value relevance of OCI and its components}

To test for the value-relevance of OCI and its components, I regress stock price on current book value, net income and OCI, using the following residual income valuation function:

$$
P / S_{i t}=b_{0}+b_{1} B V E / S_{i t}+b_{2} N I / S_{i t}+b_{3} v_{t}
$$

This approach is consistent with earlier research (Graham et al. 2003; Dechow et al. 1999; Kanagaretnam et al. 2009). $P / S_{i t}$ is the price per share of firm $i$ at time $t, B V E / S_{i t}$ is the book value per share of firm $i$ at time $t, N I / S_{i t}$ is the net income per share for the period $t$, and $v$ is other information (on a per share basis) about future abnormal earnings reflected in the firm's equity but not in the firm's financial statements, in this case, OCI per share.

Some authors suggest that using non-linear models such as arctan may produce better fit with the data (Brimble and Hodgson 2004; Goncharov and Hodgson 2008). The idea here is that the regressions follow an S-shape, which may be a closer fit to what Ohlson (1999) envisages for transitory earnings. Once they get picked up dollar-for-dollar in firm value, their future effect on earnings is close to zero, hence the slope of the curve before and after the event period would be flat. However, their approach is not very common in the literature, and hence, I choose to opt for linear regressions. 


\subsubsection{Valuation (Level) Regressions to test value-relevance of OCI and components}

Consistent with Kanagaretnam et al. (2009), I investigate the association between stock price and changes in components of other comprehensive income (OCI). Kanagaretnam et al. point out that their sample, being composed of the largest Canadian firms that are also listed in the U.S., is likely to be positively biased towards a higher incidence of use of hedge accounting and foreign currency translations. Thus, in keeping with the predicted value irrelevance of transitory earnings (Ohlson 1999), there should be no significant association for a sample that includes smaller, nonU.S. listed Canadian firms. On the other hand, if comprehensive income is indeed value relevant, then there should be a positive association between components of OCI and stock market price. Kanagaretnam et al. (2009) do not find a significant association between stock price and the foreign currency translation adjustment FOREX $X_{i t}$. This could be an artefact of the time period under consideration. Given the appreciation of the Canadian dollar versus the U.S. dollar from 2002 to 2010, I retain this variable.

Figure 1 shows the sustained change in the exchange rate for the Canadian Dollar (CAD) versus other significant currencies. Curiously, although we notice a similar pattern for the change in the exchange rate for the CAD versus the U.S. Dollar (USD), Chinese Renminbi (RMB), Mexican Peso (MXN) and the Japanese Yen (YEN), the pattern is somewhat different for the CAD versus the Euro (EUR) and the British Pound (GBP). This is possibly because the former currencies are marked to the U.S. Dollar, while the latter ones aren't. In almost all cases, we notice a sustained strengthening of the Canadian dollar. The effect of a sustained change in exchange rates on the foreign currency translation has been documented in the literature (DavisFriday and Gordon 2005), although there remains some debate about the direction of the effect (Louis 2001). 


\section{Figure 1: Exchange rates for the Canadian Dollar against selected currencies $^{26}$}

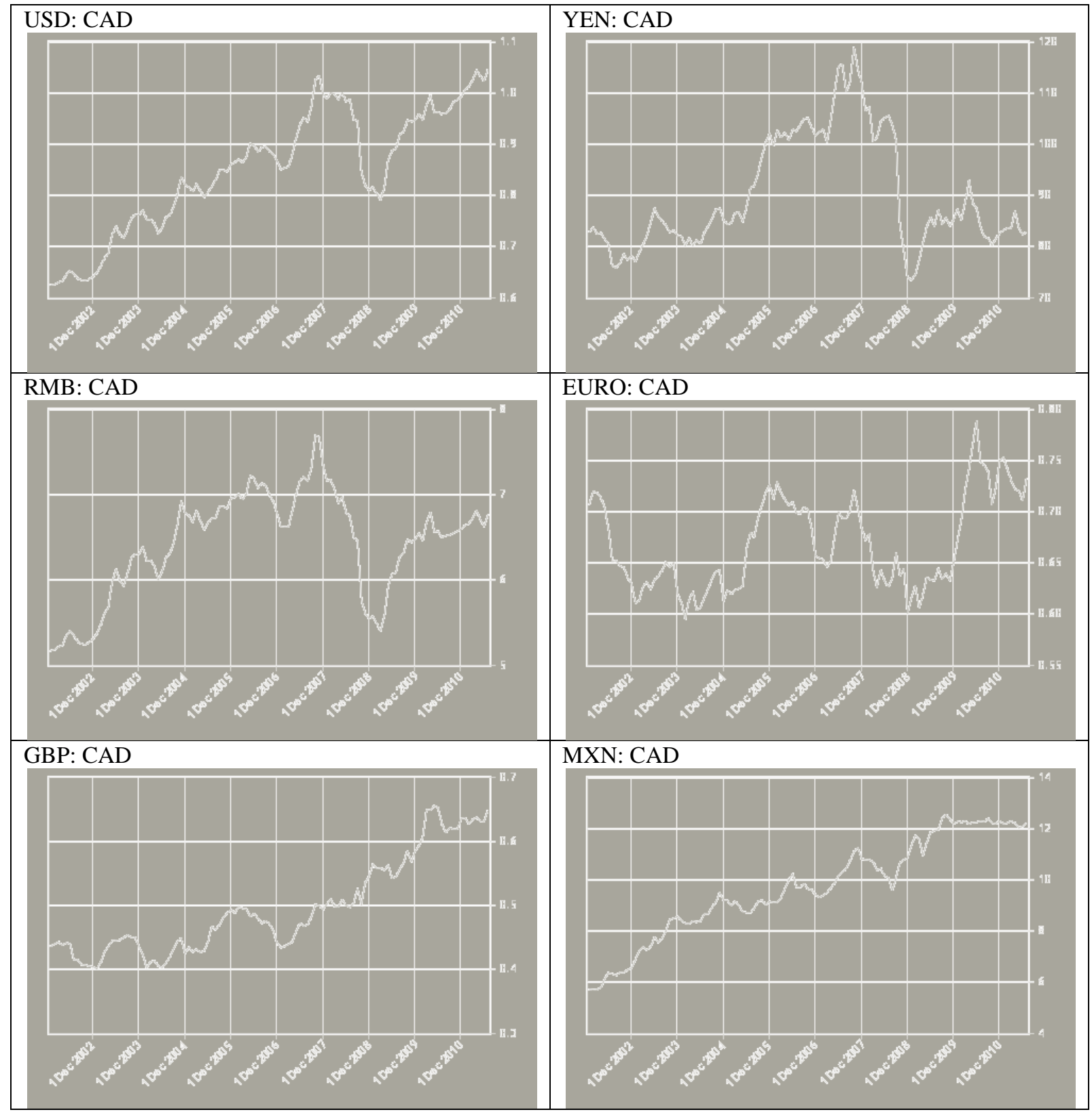

source: Bank of Canada

http://www.bankofcanada.ca/rates/exchange/cad-selected-currencies/?page moved=1\#IEXM2001

accessed on August 30, 2011

${ }^{26}$ Due to the background color used in the charts, the dates on the horizontal axis are not clearly visible. These dates are all year-end (December 31) for the years 2002 through 2010. 
Interest rates can also play a role in the change in fair value of investments as well as exchange rate fluctuations. As Figure 2 below shows, the monthly bank rate in Canada has changed frequently, and sometimes quite sharply. While on the most part this is probably in response to macroeconomic pressures or to changes in the U.S. interest rates, such interest rate changes would also have contributed to the other comprehensive income of many Canadian firms.

Figure 2: Historical Canadian Bank rates

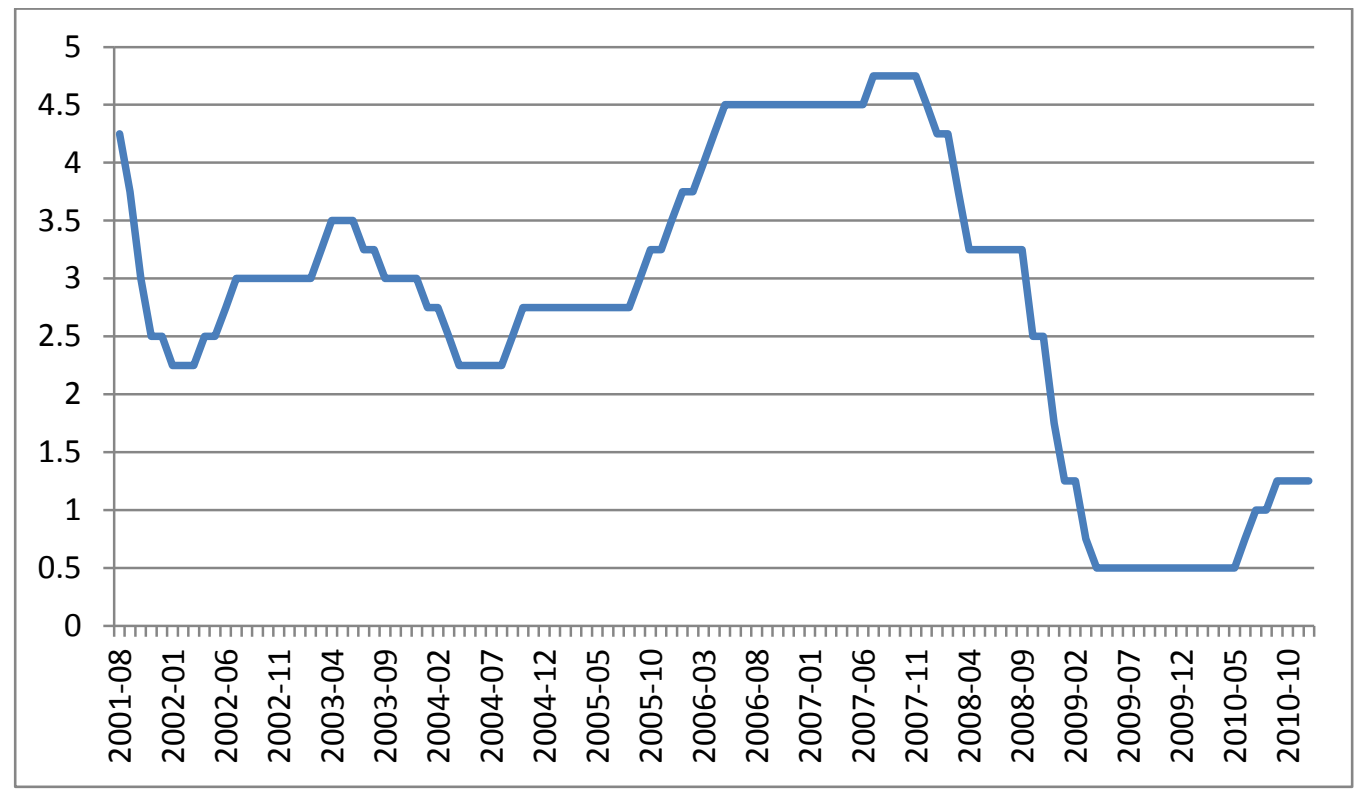

source: Bank of Canada http://www.bankofcanada.ca/rates/interest-rates/canadian-interest-rates

Cash flow hedges are one way that companies may protect themselves from interest rate and currency-exchange rate shocks. Kanagaretnam et al. (2009) use an interaction term to account for losing and winning hedging positions, and report a marginally significant positive coefficient on the interaction term HEDGE_GAIN ${ }_{i t}$, and a marginally significant negative coefficient for $H E D G E_{i t}$. Kanagaretnam et al speculate that this result could be attributed to a favourable market opinion for companies engaging in risk management, regardless of actual results of such hedges. I use only the $H E D G E_{i t}$ variable in my association tests, and estimate the following set of valuation regressions:

$P / S_{i t}=\gamma_{0}+\gamma_{1} B V E / S_{i t}+\gamma_{2} N I / S_{i t}+\gamma_{3} O C I_{1530} / S_{i t}+\varepsilon_{i t}[3 \mathrm{a}]$ 


$$
\begin{aligned}
P / S_{i t} & =\gamma_{0}+\gamma_{1} B V E / S_{i t}+\gamma_{2} N I / S_{i t}+\gamma_{3} \text { OCI }_{130} / S_{i t}+\varepsilon_{i t}[3 \mathrm{~b}] \\
P / S_{i t} & =\gamma_{0}+\gamma_{1} B V E / S_{i t}+\gamma_{2} N I / S_{i t}+\gamma_{3} H E D G E / S_{i t}+\gamma_{4} S E C / S_{i t}+\gamma_{5} F O R E X / S_{i t}+\varepsilon_{i t}[3 \mathrm{c}] \\
P / S_{i t} & =\gamma_{0}+\gamma_{1} B V E / S_{i t}+\gamma_{2} N I / S_{i t}+\gamma_{3} H E D G E / S_{i t}+\gamma_{4} S E C / S_{i t}+\gamma_{5} F O R E X / S_{i t}+\gamma_{6} P E N A D J / S_{i t}+\varepsilon_{i t}
\end{aligned}
$$

where

$P / S_{i t} \quad$ the stock price of firm $i$ three months after the end of fiscal year $t$;

$B V E / S_{i t} \quad$ the book value of common equity per share at the end of the fiscal year $t$;

$N I / S_{i t} \quad$ net income per share after extraordinary items and discontinued operations for the fiscal year $t$

Other variables are as defined earlier.

Ohlson (1999) models stock price as a function of book value, abnormal earnings and transitory earnings (namely, OCI), and specifies the following equation: $P_{t}=b_{t}+\alpha_{1} x_{t}^{a}+\alpha_{2} x_{2 t}$. Following Ohlson (1999), I also test specifically for value irrelevance by modeling stock price as a function of book value, abnormal earnings and OCI. Ohlson predicts that the sum of the coefficients on abnormal earnings and OCI in the above valuation regression would be zero, i.e. $\alpha_{1}+\alpha_{2}=0$. I test for this by carrying out an incremental F-test similar to that described in section 5.1.1. using the following equations:

$P / S_{i t}=\gamma_{0}+\gamma_{1} B V E / S_{i t}+\gamma_{2}$ AbnEarn $_{i t}+\gamma_{3} O C I_{1530} / S_{i t}+\varepsilon_{i t}[3 e]$

$P / S_{i t}=\gamma_{0}+\gamma_{1} B V E / S_{i t}+\gamma_{2}$ AEDiffOCI $_{i t}+\varepsilon_{i t}[3 f]$

where the variables are as defined in earlier sections.

Equation 3e above serves as the unconstrained model, while equation $3 \mathrm{f}$ is the constrained model.

\subsubsection{Returns (Change) Regressions to test value-relevance of OCI and components}

Kothari and Zimmerman (1995) suggest that price models are better specified than returns models in that their estimated slope coefficients and earnings response coefficients are less biased. However, return models have less serious econometric problems, and therefore, the 
combined use of both price and return models may be useful in some research contexts. Therefore, I follow Kanagaretnam et al (2009), and run the following returns regressions, numbered 4a through 4d. As a specification check, consistent with Chambers et al. (2007), I use dummy variables to test for possible differences in pricing of OCI and its components in the post-2006 period (i.e. the period in which OCI reporting became mandatory under section 1530) and for loss-making firm-years (Hayn 1995). In regression equation 4e, $\mathrm{D}_{1}$ is an indicator variable that is coded 1 for years in which NI is negative. $\mathrm{D}_{2}$ is a dummy variable which is coded 1 for post 2006 years.

$$
\begin{aligned}
& R E T_{i t}=\phi_{0}+\phi_{1} N I_{i t}+\phi_{2} O C I_{1530 i t}+\varepsilon_{i t} \\
& R E T_{i t}=\phi_{0}+\phi_{1} N_{i t}+\phi_{2} O_{130 i t}+\varepsilon_{i t} \\
& R E T_{i t}=\phi_{0}+\phi_{1} N_{i t}+\phi_{2} H E D G E_{i t}+\phi_{3} S E C_{i t}+\phi_{4} F O R E X_{i t}+\varepsilon_{i t} \\
& R E T_{i t}=\phi_{0}+\phi_{1} N I_{i t}+\phi_{2} H E D G E_{i t}+\phi_{3} S E C_{i t}+\phi_{4} F O R E X_{i t}+\phi_{5} P E N A D J_{t}+\varepsilon_{i t} \quad \text { [4d] } \\
& R E T_{i t}=\phi_{0}+\phi_{1} N I_{i t}+\phi_{2} H E D G E_{i t}+\phi_{3} S E C_{i t}+\phi_{4} F O R E X_{i t}+\phi_{5} P E N A D J_{t}+\phi_{6} D_{1} * N I_{i t} \\
& +\phi_{7} D_{2} * N I_{i t}+\varepsilon_{i t}
\end{aligned}
$$

where (all variables other than RET are scaled by the market value of common equity at the beginning of the fiscal year),

$R E T_{i t} \quad$ stock returns (inclusive of dividends) for the year ended three months after the end of fiscal year t.

$N_{\text {it }} \quad$ net income for the fiscal year $\mathrm{t}$ under Canadian GAAP after extraordinary items and discontinued operations;

$D_{1} \quad$ Dummy variable coded 1 if the net income for the year was negative

$D_{2} \quad$ Dummy variable coded 1 if the year was 2006 and after

Other variables are as described in section 5.1.1

\subsection{Testing for association of OCI and its components with analysts' earnings forecasts}

I test for the association of OCI and its components with analysts' earnings forecasts in two ways. First, I regress mean and median analyst earnings forecasts on the lagged earnings per 
share and current year- and lagged-OCI and its components. Secondly, I regress analysts' forecast error on OCI and its components, while controlling for forecast dispersion, firm size, trading volume and analyst following.

\subsubsection{Regressions to test association of OCI and components with analyst forecasts}

I use two alternative measures of analysts' earnings forecasts - the consensus mean EPS and the median of the analysts’ EPS estimates. As pointed out by Gu and Wu (2003), the median forecast is more accurate than the mean due to earnings skewness. However, the mean forecast has been used in other studies (for example, (Barth and Hutton 2004)), so I choose to retain it as well.

$$
\begin{aligned}
& \text { IBESMean }_{i t}=\varphi_{0}+\varphi_{1} \text { EPS }_{i t-1}+\varphi_{2} \text { LnMVE }_{i t-1}+\varphi_{3} \operatorname{LnTV}_{i t}+\varphi_{4} \text { LnFol }_{i t}+\varphi_{5} \text { OCI }_{1530 i t-1} \\
& +\varphi_{6} O C I_{1530 i t}+\varepsilon_{i t} \\
& \text { IBESMean }_{i t}=\varphi_{0}+\varphi_{1} \text { EPS }_{i t-1}+\varphi_{2} \text { LnMVE }_{i t-1}+\varphi_{3} \operatorname{LnTV}_{i t}+\varphi_{4} \operatorname{LnFol}_{i t}+\varphi_{5}{\text { HEDGE } / S_{i t}}+\varphi_{6} \text { SEC/S }_{i t}+
\end{aligned}
$$

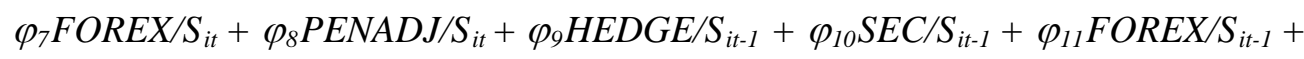

$$
\begin{aligned}
& \varphi_{12} \text { PENADJ/S }{ }_{i t-1}+\varepsilon_{i t} \\
& \text { IBESMed }_{i t}=\varphi_{0}+\varphi_{1} \text { EPS }_{i t-1}+\varphi_{2} \operatorname{LnMVE}_{i t-1}+\varphi_{3} \operatorname{LnTV}_{i t}+\varphi_{4} \text { LnFol }_{i t}+\varphi_{5} \text { OCI }_{1530 i t-1} \\
& +\varphi_{6} \mathrm{OCI}_{1530 i t}+\varepsilon_{i t} \\
& \operatorname{IBESMed}_{i t}=\varphi_{0}+\varphi_{1} \mathrm{EPS}_{i t-1}+\varphi_{2} \operatorname{LnMVE}_{i t-1}+\varphi_{3} \operatorname{LnTV}_{i t}+\varphi_{4} \operatorname{LnFol}_{i t}+\varphi_{5} H E D G E / S_{i t}+\varphi_{6} S E C / S_{i t}+
\end{aligned}
$$

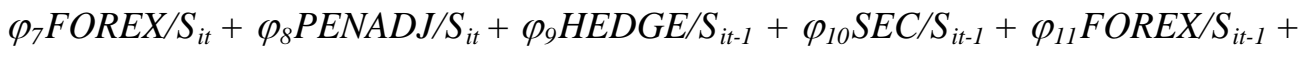

$$
\begin{aligned}
& \varphi_{12} P E N A D J / S_{i t-1}+\varepsilon_{i t}
\end{aligned}
$$

where,

IBESMean $_{i t}$ is the mean analysts' forecast estimate from I/B/E/S of Earnings per share (EPS) for firm $i$ immediately preceding earnings announcement

IBESMed $_{i t}$ is the median analysts' forecast estimate from I/B/E/S of EPS for firm $i$ immediately preceding earnings announcement

$E P S_{i t-1}$ is the actual EPS for firm $i$ for immediately preceding fiscal year

$L_{n M V E}$ it-1 is the natural log of market value of equity for firm $i$ at the beginning of fiscal year 
$\operatorname{LnTV}_{i t}$ is the natural log of average trading volume for firm $i$ stock

$\mathrm{LnFol}_{i t}$ is the natural log of number of analysts providing earnings forecasts for firm $i$ shares

Other variables are as defined in earlier sections

\subsubsection{Regressions to test association of OCI and components with analyst forecast error}

A number of studies document the existence of analyst forecast bias, which may arise due to incentive effects (Karamanou 2000), analysts’ desire to gain access to management (Das et al. 1998; Libby et al. 2008), or perhaps because of analysts trying to correct for earnings skewness (Gu and Wu 2003). Extant research also documents the market's ability to adjust for analysts' forecast bias, to the extent that potentially profitable trading strategies could be devised by incorporating the effects of such bias (Karamanou 2000; Han et al. 2001; Hughes et al. 2008). The extent of analyst forecast bias has been found to be reducing in the face of increased regulations (Bradshaw 2009; Chen and Chen 2009), at least in the case of short-term forecasts (Srinidhi et al. 2009).

The above research notwithstanding, analysts’ forecasts remain an important source of information for markets, and thus, the question whether OCI and its components are associated with analyst earnings forecast errors is important. To test for the potential association, I test the following regressions. I control for several variables, including the dispersion between the mean and median consensus forecasts, accruals, firm size, trading volume, analyst following and for loss making firms.

$$
\begin{aligned}
& \text { FERR }_{i t}=\lambda_{0}+\lambda_{1} \text { MNMD }_{i t}+\lambda_{2} \text { Accruals }_{S_{i t}}+\lambda_{3} \operatorname{LnMVE}_{i t-1}+\lambda_{4} \operatorname{LnTV}_{i t}+\lambda_{5} \operatorname{LnFol}_{i t}+\lambda_{6} \mathrm{NegNI}+ \\
& \lambda_{7} \mathrm{OCI}_{1530 i t}+\varepsilon_{i t} \\
& \text { FERR }_{i t}=\lambda_{0}+\lambda_{1} \text { MNMD }_{i t}+\lambda_{2}{\text { Accruals } / S_{i t}}+\lambda_{3} \operatorname{LnMVE}_{i t-1}+\lambda_{4} \operatorname{LnTV}_{i t}+\lambda_{5} \operatorname{LnFol}_{i t}+\lambda_{6} \mathrm{NegNI}+ \\
& \lambda_{7} \mathrm{HEDGE} / \mathrm{S}_{i t}+\lambda_{8} \mathrm{SEC} / \mathrm{S}_{i t}+\lambda_{9} \mathrm{FOREX} / S_{i t}+\lambda_{9} \mathrm{PENADJ} / \mathrm{S}_{i t}+\varepsilon_{i t}
\end{aligned}
$$

where the variables are as defined in earlier sections

\subsection{Control Variables}

As part of my tests of robustness, I control for the following: 
1. $L n T A / S_{i t}$ : I use the natural logarithm of the book value of total assets per share of firm $i$ for the fiscal year $t$, to control for size (Nikolaev 2010). Since the seminal paper on Positive Accounting Theory by Watts and Zimmerman (1978) it has become common practice to use firm size as a control against possible omitted variable biases (Bujaki and Richardson 1997).

2. DebtEquity ${ }_{i t}$ : Debt-to-Equity ratio, a common proxy of leverage (Duke and Hunt 1990), to control for possible agency incentives to manage earnings by timing the realization of gains and losses, which would result in a transfer from accumulated other comprehensive income to net income (Cheng and Warfield 2005; Dechow and Sloan 1991). It should be noted that the debt-equity ratio is correlated with stock beta, it could yet be incrementally associated with stock returns (Fama and French 1992).

3. Industry Dummy variables: Dhaliwal et al (1999) showed that items of OCI might be significant for firms in the financial industry. Indeed, the amount of OCI is often larger in firms belonging to some industries than others. For example, financial firms would have greater exposure to financial instruments including available-for-sale securities. Resource extraction firms such as those in the Oil and Gas industry may be exposed to foreign currency risks, and may be involved in hedging their risks through cash flow and other hedging mechanisms.

4. The years 2007-2008 witnessed a period of acute economic recession which triggered a steep decline in major capital markets globally. It may be recalled that HB1530 became effective for firm years beginning on or after October 1, 2006. This means that companies with a fiscal year starting just prior to this date, were not required (although early adoption was permitted) to adopt the standard until their next fiscal, which started later in 2007. Effectively, these companies would have until the year 2008 to report their OCI numbers. To control for a possible bias arising from the time of adoption of HB1530 by individual firms, I use a dummy variable which is coded 1 for firm years 2007 and 2008, and zero for other years. The logic here is that if there exists a bias arising purely from the difference in the time of adoption of the standard, I should find statistical significance for this dummy variable. 


\subsection{Data procedures}

The sample for this study is drawn from Canadian firms listed on the S\&P/TSX Composite Index, which is an index of the largest Canadian companies in terms of market capitalization, and accounts for approximately seventy percent of the market capitalization of firms listed on the Toronto Stock Exchange. HB1530 came into effect for firm years beginning October 2006. As such, 2007 is the first fiscal year for which any mandatorily-reported data are available. However, due to SEC reporting requirements, several firms cross-listed on U.S. exchanges were already reporting comprehensive income information under SFAS 130.

The first step in data collection involved identifying firms for which data should be collected. This was done by retrieving the index constituents for the S\&P/TSX Composite Index for financial years 2001 through 2010 from the Compustat database. This step generated a list of 617 companies. Using this list, data on stock prices and accounting information was collected. This step generated 4,206 firm-year-observations. Observations which did not contain information on stock price or book-value were deleted, resulting in a final list of 3,969 firm-year observations for 535 companies. The full list of companies is included in Appendix 1. Data on analysts' earnings forecasts was collected from the I/B/E/S database accessed through Wharton Research Data Services (WRDS). A total of 2,359 observations were collected. These data were merged with the data collected from Compustat.

\subsubsection{Missing data}

There was considerable missing data, especially for OCI and its components. This is not surprising, given that HB1530 came into effect for financial years starting October 1, 2006, and its full effect was not seen until fiscal 2007. Data on OCI and components was available for very few firms for earlier periods. These were firms which were either using US-GAAP for accounting, or provided the information for US SEC filings.

If a firm reported data for any component of OCI, I replaced the missing values for the other components with zero. For example, a firm might have reported a value for SEC, but nothing for FOREX and HEDGE. In such a case, I inserted a null value for FOREX and HEDGE. 
For the first instance of a firm reporting data for any component of OCI, I inserted zeroes for the lagged values, so as not to lose too many observations. It may be noted that replacing such missing data by zeroes actually results in a weakening of the power of the results, and thus, my results are possibly more conservative than what would be the case otherwise.

For other instances of firm year observations with missing data, I used list-wise deletion. List-wise deletion is the preferred approach for dealing with missing data in the accounting literature, although it does have the disadvantage of reducing the sample size.

\subsubsection{Outliers}

To make my regression results comparable with those of Kanagaretnam et al (2009), I ran initial multivariate regressions for each model and saved the studentized residuals for each regression. I then excluded firm-year observations with an absolute Z-Student score of greater than 3. Coupled with list-wise deletion, this procedure of excluding multivariate outliers resulted in a substantial diminution in my sample size. For various regressions, the sample size ranged between 675 and 1464 firm-year observations. The following chapter presents descriptive statistics and results of regression analyses. 


\section{Chapter Six: Results}

\subsection{Descriptive statistics}

Table 6-1 presents the descriptive statistics for the variables used in the tests. The descriptive statistics include the number of observations $(\mathrm{N})$, the mean, the standard deviation, and the quartile values (the $25^{\text {th }}, 50^{\text {th }}$ and $75^{\text {th }}$ percentiles) for each variable. The table is split into panels A through F. Panel A describes the variables testing the forecasting ability and predictability of OCI and its components. Panel B presents the descriptive statistics for the variables used in testing the predictability of OCI and its components. Panel C describes the variables used in the valuation or price regressions to test the value relevance of OCI and its components. Panel D describes the variables used in the returns regressions to test the value relevance of OCI and its components. Panel E describes variables used in testing the association between analysts' earnings forecasts and OCI and its components. Finally, Panel F describes variables used in testing the association between analysts’ earnings forecast errors and OCI and its components.

As it can be seen from table 6.1, the median value for OCI ( $50^{\text {th }}$ percentile) items is zero, while the mean values are mostly negative. This is likely the result of the time period covered in this study, which included a prolonged period of economic recession, and slumps in fair values of financial assets. In terms of materiality, aggregate OCI per share constitutes approximately 7.3 per cent of total comprehensive income ${ }^{27}$. However, the materiality of the per-share unrealized gains and losses on available for sale securities (SEC) is much higher at 9.8 per cent. The mean values of the other components of OCI were all negative for the sample, and other than the FOREX (2 per cent), are not material.

\footnotetext{
${ }^{27}$ Mean Comprehensive Income per share $=$ Mean Net Income per share + Mean $\mathrm{OCI}_{1530}$ per share $=.8289+.0657$ $=0.8946$

$\mathrm{OCI}_{1530}$ as percentage of comprehensive income $=.0657 / .8946=0.073$

SEC as a percentage of comprehensive income $=.0877 / .8946=0.098$

FOREX as a percentage of comprehensive income $=-.0179 / .8946=.020$
} 
Table 6-1: Descriptive Statistics

Panel A: Variables used in regressions testing the Forecasting Ability of OCI and components

\begin{tabular}{lllllll}
\hline Variables & $\mathrm{N}$ & Mean & $\begin{array}{l}\text { Standard } \\
\text { Deviation }\end{array}$ & $25 \%$ & $50 \%$ & $75 \%$ \\
\hline AbnEarn $_{\text {it }}$ & 1074 & -.5028 & 2.0430 & -.8894 & -.2386 & .2830 \\
OCI $_{1530 i t-1}$ & 1074 & -.0583 & 1.3565 & -.0847 & .0000 & .0401 \\
OCI $_{130 i t-1}$ & 1074 & -.0609 & 1.3593 & -.0926 & .0000 & .0431 \\
HEDGE & 1074 & -.0090 & .7453 & .0000 & .0000 & .0000 \\
SEC $_{i t-1}$ & 1074 & -.0233 & .6645 & .0000 & .0000 & .0000 \\
FOREX & 1074 & -.0259 & .8137 & -.0223 & .0000 & .0005 \\
PENADJ & 1074 & -.0027 & .0845 & .0000 & .0000 & .0000
\end{tabular}

Panel B: Variables used in regressions testing the Predictability of OCI and components

\begin{tabular}{lllllll}
\hline Variables & $\mathrm{N}$ & Mean & $\begin{array}{l}\text { Standard } \\
\text { Deviation }\end{array}$ & $25 \%$ & $50 \%$ & $75 \%$ \\
\hline AbnEarn $_{\text {it }}$ & 1074 & -.5028 & 2.0430 & -.8894 & -.2386 & .2830 \\
OCI $_{1530 i t}$ & 1074 & .0308 & 1.8031 & -.0822 & .0000 & .0631 \\
OCI $_{130 i t}$ & 1074 & .0245 & 1.8087 & -.0913 & .0000 & .0643 \\
HEDGE $_{i t}$ & 1074 & -.0052 & .7502 & .0000 & .0000 & .0000 \\
SEC $_{i t}$ & 1074 & .0393 & 1.2407 & .0000 & .0000 & .0000 \\
FOREX & 1074 & -.0033 & .7786 & -.0483 & .0000 & .0000 \\
PENADJ & 1074 & -.0063 & .1279 & .0000 & .0000 & .0000
\end{tabular}

Panel C: Variables used in Valuation regressions testing the Value Relevance of OCI and components

\begin{tabular}{|c|c|c|c|c|c|c|}
\hline Variables & $\mathrm{N}$ & Mean & $\begin{array}{l}\text { Standard } \\
\text { Deviation }\end{array}$ & $25 \%$ & $50 \%$ & $75 \%$ \\
\hline$P / S_{i t}$ & 1464 & 18.8633 & 26.8991 & 5.4550 & 13.3700 & 26.2227 \\
\hline$B V E / S_{i t}$ & 1464 & 12.5767 & 31.2102 & 3.1771 & 7.8892 & 13.8948 \\
\hline$N I / S_{i t}$ & 1464 & .8289 & 3.5364 & -.1035 & .5225 & 1.5365 \\
\hline$O C I / S_{1530 i t}$ & 1464 & .0657 & 3.3699 & -.0741 & .0000 & .0399 \\
\hline$O C I / S_{130 i t}$ & 1464 & .0600 & 3.3722 & -.0818 & .0000 & .0404 \\
\hline$H E D G E / S_{i t}$ & 1464 & -.0041 & .6461 & .0000 & .0000 & .0000 \\
\hline$S E C / S_{i t}$ & 1464 & .0877 & 3.1422 & .0000 & .0000 & .0000 \\
\hline$F O R E X / S_{i t}$ & 1464 & -.0179 & .7633 & -.0321 & .0000 & .0000 \\
\hline$P E N A D J / S_{i t}$ & 1464 & -.0056 & .1109 & .0000 & .0000 & .0000 \\
\hline AbnEarn $_{i t}$ & 1464 & -.5970 & 5.1876 & -.8697 & -.2179 & .2968 \\
\hline
\end{tabular}


From Panel D, it can be inferred that the mean return on stock was 8.54 per cent, with a standard deviation of 52.92 per cent. From panels E and F, it can be seen that on average, analysts tended to produce mean earnings forecasts that were more conservative (negative forecast error implies that the forecast earnings were lower than actual earnings), and tended to be more precise, i.e. not widely distributed (the Mean-Median difference was low).

Panel D: Variables used in Returns regressions testing the Value Relevance of OCI and components

\begin{tabular}{lllllll}
\hline Variables & $\mathrm{N}$ & Mean & $\begin{array}{l}\text { Standard } \\
\text { Deviation }\end{array}$ & $25 \%$ & $50 \%$ & $75 \%$ \\
\hline Ret $_{i t}$ & 1097 & .0854 & .5293 & -.2792 & .0618 & .3794 \\
$N_{i t}$ & 1097 & .0092 & .3507 & -.0051 & .0525 & .0880 \\
OCI $_{1530 i t}$ & 1097 & .0056 & .1635 & -.0113 & -.0001 & .0093 \\
OCI $_{130 i t}$ & 1097 & .0053 & .1635 & -.0121 & -.0003 & .0093 \\
HEDGE $_{i t}$ & 1097 & .0048 & .1135 & -.0002 & .0000 & .0002 \\
SEC $_{i t}$ & 1097 & .0022 & .0359 & .0000 & .0000 & .0000 \\
FOREX $_{i t}$ & 1097 & -.0014 & .1135 & -.0088 & .0000 & .0023 \\
PENADJ $_{i t}$ & 1097 & -.0003 & .0089 & .0000 & .0000 & .0000
\end{tabular}

Panel E: Variables used in regressions testing the association between $\mathrm{OCI}$ and components and Analysts' Earnings Forecasts

\begin{tabular}{|c|c|c|c|c|c|c|}
\hline Variables & $\mathrm{N}$ & Mean & $\begin{array}{l}\text { Standard } \\
\text { Deviation }\end{array}$ & $25 \%$ & $50 \%$ & $75 \%$ \\
\hline IBESMean $_{i t}$ & 675 & 1.1549 & 1.7859 & .0900 & .7900 & 1.6800 \\
\hline IBESMed $_{i t}$ & 675 & 1.1567 & 1.8063 & .0900 & .7900 & 1.6800 \\
\hline$E P S_{i t}$ & 675 & 1.0762 & 2.4875 & -.0200 & .7900 & 1.7900 \\
\hline$L n M V E_{i t}$ & 675 & 7.4119 & 1.4730 & 6.4553 & 7.2996 & 8.2383 \\
\hline$L n T V_{i t}$ & 675 & 15.5393 & 1.8374 & 14.6226 & 15.7653 & 16.6444 \\
\hline $\operatorname{LnFol}_{i t}$ & 675 & 1.5977 & .8733 & 1.0986 & 1.7918 & 2.3026 \\
\hline$O C I / S_{1530 i t}$ & 675 & -.0226 & 1.2149 & -.1001 & .0000 & .0517 \\
\hline$H E D G E / S_{i t}$ & 675 & -.0208 & .8617 & -.0018 & .0000 & .0000 \\
\hline$S E C / S_{i t}$ & 675 & -.0430 & .4007 & .0000 & .0000 & .0000 \\
\hline FOREX/S ${ }_{i t}$ & 675 & .0412 & .8428 & -.0130 & .0000 & .0247 \\
\hline$P_{E N A D J_{i t}}$ & 675 & -.0016 & .0963 & .0000 & .0000 & .0000 \\
\hline
\end{tabular}


Panel F: Variables used in regressions testing the association between OCI and components and Analysts' Earnings Forecast Errors

\begin{tabular}{|c|c|c|c|c|c|c|}
\hline Variables & $\mathrm{N}$ & Mean & $\begin{array}{l}\text { Standard } \\
\text { Deviation }\end{array}$ & $25 \%$ & $50 \%$ & $75 \%$ \\
\hline$F^{\prime} E R R_{i t}$ & 675 & -0.0292 & 0.1952 & -0.0223 & -0.0017 & 0.0077 \\
\hline$M N M D_{i t}$ & 675 & -0.0005 & 0.0087 & -0.0002 & 0.0000 & 0.0002 \\
\hline Accruals/S $S_{i t}$ & 675 & 1.4766 & 3.3572 & 0.1424 & 0.7889 & 1.9512 \\
\hline $\operatorname{LnMVE}_{i t}$ & 675 & 7.4119 & 1.4730 & 6.4553 & 7.2996 & 8.2383 \\
\hline $\operatorname{LnTV_{it}}$ & 675 & 15.5393 & 1.8374 & 14.6226 & 15.7653 & 16.6444 \\
\hline LnFol $_{i t}$ & 675 & 1.5977 & .8733 & 1.0986 & 1.7918 & 2.3026 \\
\hline OCI $/ S_{1530 i t}$ & 675 & -.0226 & 1.2149 & -.1001 & .0000 & .0517 \\
\hline$H E D G E / S_{i t}$ & 675 & -.0208 & .8617 & -.0018 & .0000 & .0000 \\
\hline$S E C / S_{i t}$ & 675 & -.0430 & 4007 & .0000 & .0000 & .0000 \\
\hline$F O R E X / S_{i t}$ & 675 & .0412 & .8428 & -.0130 & .0000 & .0247 \\
\hline$P{ }^{\prime} N A J_{i t}$ & 675 & -.0016 & .0963 & .0000 & .0000 & .0000 \\
\hline
\end{tabular}

Table 6.2 presents the correlation matrix and the Pearson correlation coefficients for the variables used in the regressions. The data are segregated into panels A through $\mathrm{E}$ to correspond with the different sets of association tests. Panel A presents the correlation matrix and the Pearson correlation coefficients for the variables used in testing the forecasting ability of OCI and its components. Panel B presents the correlation matrix and the Pearson correlation coefficients for the variables used in testing the predictability of OCI and its components. Panel $\mathrm{C}$ presents the correlation matrix and the Pearson correlation coefficients for the variables used in the valuation or price regressions to test the value relevance of OCI and its components. Panel D presents the correlation matrix and the Pearson correlation coefficients for the variables used in the returns regressions to test the value relevance of OCI and its components. Panel E presents the correlation matrix, and the Pearson correlation coefficients, for variables used in testing the association between analysts' earnings forecasts and OCI and its components. Finally, Panel F presents the correlation matrix and the Pearson correlation coefficients for variables used in testing the association between analysts' earnings forecast errors and OCI and its components.

Significant correlations are marked with $(*)$ for $\mathrm{p}<.05$ and $(* *)$ for $\mathrm{p}<.01$. None of the correlations is so large as to suggest multicollinearity, except for book value per share (BV/S) 
and stock price (P/S), where the correlation is quite strong (please see Panel C). However, conceptually, this is to be expected. $\mathrm{OCI}_{1530}$ and $\mathrm{OCI}_{130}$ are highly correlated, which is expected, given that they are almost identical constructs. However, they are never included in the same equation together.

As can be seen from panel A of Table 6.2, lagged values of OCI and HEDGE are significantly and positively correlated with abnormal earnings. As expected, PENADJ is significantly, and negatively, correlated with abnormal earnings. This helps condition expectations for the ability of OCI and at least some of its components to forecast future abnormal earnings. Panel B shows that lagged values of aggregate $\mathrm{OCI}_{1530}$ and all three of its components are significantly and negatively correlated with current $\mathrm{OCI}_{1530}$. This conforms to the expectation that OCI items tend to display negative persistence, i.e. they tend to reverse over time. Lagged PENADJ is not significantly associated with either $\mathrm{OCI}_{130}$ or $\mathrm{OCI}_{1530}$. Interestingly, lagged abnormal earnings are significantly positively correlated with OCI.

Panel C shows that except for HEDGE, aggregate $\mathrm{OCI}_{1530}$ and its components are significantly correlated with stock price. However, PENADJ and abnormal earnings (AbnEarn) are significantly negatively correlated with stock price. While the negative correlation for PENADJ can be explained by the market's expectation of higher pension costs in the future, the negative correlation for abnormal earnings is puzzling. Panel D indicates that aggregate $\mathrm{OCI}_{1530}$ and all of its components are also significantly correlated with stock returns, while PENADJ is not. These correlations help condition expectations of value relevance of OCI and its components.

As panel E indicates, while aggregate $\mathrm{OCI}_{1530}$ is not significantly correlated with mean (or median) analysts' earnings forecasts. Among its individual components, only SEC is found to be negatively significantly correlated with analysts' earnings forecasts. Finally, as can be seen in Panel F, accruals and aggregate $\mathrm{OCI}_{1530}$ are significantly negatively correlated with analysts' earnings forecast errors. Among its components, only HEDGE is found to be negatively significantly correlated with analysts' earnings forecast errors. PENADJ is also significantly, though positively, correlated with analysts’ earnings forecast errors. 
Table 6-2: Correlation matrices and Pearson coefficients

Panel A: Variables used in regressions testing the Forecasting Ability of OCI and components

\begin{tabular}{|c|c|c|c|c|c|c|c|c|c|}
\hline Correlations $^{\mathrm{a}}$ & & AbnEarn/S ${ }_{i t}$ & AbnEarn $/ S_{i t-1}$ & $O C I_{130} / S_{i t-1}$ & $O C I_{1530} / S_{i t-1}$ & HEDGE $/ S_{i t-1}$ & $S E C / S_{i t-1}$ & $F O R E X / S_{i t-1}$ & PENADJ $/ S_{i t-1}$ \\
\hline AbnEarn $_{\text {it }}$ & $\begin{array}{l}\text { Pearson Correlation } \\
\text { Sig. (1-tailed) }\end{array}$ & 1.000 & & & & & & & \\
\hline$A b n E a r n / S_{i t-1}$ & $\begin{array}{l}\text { Pearson Correlation } \\
\text { Sig. (1-tailed) }\end{array}$ & $\begin{array}{l}.251^{* *} \\
.000\end{array}$ & 1.000 & & & & & & \\
\hline$O C I_{130} / S_{i t-1}$ & $\begin{array}{l}\text { Pearson Correlation } \\
\text { Sig. (1-tailed) }\end{array}$ & $\begin{array}{l}.133^{* *} \\
.000\end{array}$ & $\begin{array}{c}-.342^{* *} \\
.000\end{array}$ & 1.000 & & & & & \\
\hline$O C I_{1530} / S_{i t-1}$ & $\begin{array}{l}\text { Pearson Correlation } \\
\text { Sig. (1-tailed) }\end{array}$ & $\begin{array}{l}.140^{* *} \\
.000\end{array}$ & $\begin{array}{c}-.341^{* *} \\
.000\end{array}$ & $\begin{array}{l}.998^{* *} \\
.000\end{array}$ & 1.000 & & & & \\
\hline$H E D G E / S_{i t-1}$ & $\begin{array}{l}\text { Pearson Correlation } \\
\text { Sig. (1-tailed) }\end{array}$ & $\begin{array}{l}.277^{* *} \\
.000\end{array}$ & $\begin{array}{r}-.018 \\
.283\end{array}$ & $\begin{array}{l}.537^{* *} \\
.000\end{array}$ & $\begin{array}{l}.538^{* *} \\
.000\end{array}$ & 1.000 & & & \\
\hline$S E C / S_{i t-1}$ & $\begin{array}{l}\text { Pearson Correlation } \\
\text { Sig. (1-tailed) }\end{array}$ & $\begin{array}{l}-.010 \\
.376\end{array}$ & $\begin{array}{c}-.440^{* *} \\
.000\end{array}$ & $\begin{array}{l}.607^{* *} \\
.000\end{array}$ & $\begin{array}{l}.609^{* *} \\
.000\end{array}$ & $\begin{array}{l}.010 \\
.376\end{array}$ & 1.000 & & \\
\hline$F O R E X / S_{i t-1}$ & $\begin{array}{l}\text { Pearson Correlation } \\
\text { Sig. (1-tailed) }\end{array}$ & $\begin{array}{r}-.012 \\
.347 \\
\end{array}$ & $\begin{array}{l}-.193^{* *} \\
.000 \\
\end{array}$ & $\begin{array}{l}.676^{* *} \\
.000 \\
\end{array}$ & $\begin{array}{l}.677^{* *} \\
.000 \\
\end{array}$ & $\begin{array}{r}-.028 \\
.184 \\
\end{array}$ & $\begin{array}{l}.189^{* *} \\
.000 \\
\end{array}$ & 1.000 & \\
\hline$P E N A D J / S_{i t-1}$ & $\begin{array}{l}\text { Pearson Correlation } \\
\text { Sig. (1-tailed) }\end{array}$ & $\begin{array}{l}-.115^{* *} \\
.000\end{array}$ & $\begin{array}{l}-.033 \\
.142\end{array}$ & $\begin{array}{l}.064^{*} \\
.018\end{array}$ & $\begin{array}{l}.002 \\
.474\end{array}$ & $\begin{array}{l}.003 \\
.462\end{array}$ & $\begin{array}{r}-.002 \\
.476\end{array}$ & $\begin{array}{l}.002 \\
.472\end{array}$ & 1.000 \\
\hline
\end{tabular}

**. Correlation is significant at the 0.01 level (1-tailed).

*. Correlation is significant at the 0.05 level (1-tailed).

a. Listwise $\mathrm{N}=1074$ 
Panel B: Variables used in regressions testing the Predictability of OCI and components

\begin{tabular}{|c|c|c|c|c|c|c|c|c|c|c|}
\hline Correlations $^{\mathrm{a}}$ & & $O C I / S_{1530 i t}$ & $O C I / S_{130 i t}$ & AbnEarn $/ S_{i t-1}$ & $O C I_{1530} / S_{i t-1}$ & $O C I_{130} / S_{i t-1}$ & HEDGE $/ S_{i t-1}$ & $S E C / S_{i t-1}$ & FOREX/S $S_{i t-1}$ & PENADJ $/ S_{i t-1}$ \\
\hline$O C I / S_{1530 i t}$ & $\begin{array}{l}\text { Pearson Correlation } \\
\text { Sig. (1-tailed) }\end{array}$ & 1.000 & & & & & & & & \\
\hline$O C I / S_{130 i t}$ & $\begin{array}{l}\text { Pearson Correlation } \\
\text { Sig. (1-tailed) }\end{array}$ & $\begin{array}{l}.997^{* *} \\
.000\end{array}$ & 1.000 & & & & & & & \\
\hline$A b n E a r n / S_{i t-1}$ & $\begin{array}{l}\text { Pearson Correlation } \\
\text { Sig. (1-tailed) }\end{array}$ & $\begin{array}{l}.372^{* *} \\
.000\end{array}$ & $\begin{array}{l}.370^{* *} \\
.000\end{array}$ & 1.000 & & & & & & \\
\hline$O C I_{1530} / S_{i t-1}$ & $\begin{array}{l}\text { Pearson Correlation } \\
\text { Sig. (1-tailed) }\end{array}$ & $\begin{array}{c}-.713^{* *} \\
.000\end{array}$ & $\begin{array}{c}-.710^{* *} \\
.000\end{array}$ & $\begin{array}{c}-.342^{* *} \\
.000\end{array}$ & 1.000 & & & & & \\
\hline$O C I_{130} / S_{i t-1}$ & $\begin{array}{l}\text { Pearson Correlation } \\
\text { Sig. (1-tailed) }\end{array}$ & $\begin{array}{c}-.715^{* *} \\
.000\end{array}$ & $\begin{array}{c}-.713^{* *} \\
.000\end{array}$ & $\begin{array}{l}.341^{* *} \\
.000\end{array}$ & $\begin{array}{l}.998^{* *} \\
.000\end{array}$ & 1.000 & & & & \\
\hline$H E D G E / S_{i t-1}$ & $\begin{array}{l}\text { Pearson Correlation } \\
\text { Sig. (1-tailed) }\end{array}$ & $\begin{array}{l}-.180^{* *} \\
.000\end{array}$ & $\begin{array}{l}-.181^{* *} \\
.000\end{array}$ & $\begin{array}{l}-.018 \\
.283\end{array}$ & $\begin{array}{l}.537^{* *} \\
.000\end{array}$ & $\begin{array}{l}.538^{* *} \\
.000\end{array}$ & 1.000 & & & \\
\hline$S E C / S_{i t-1}$ & $\begin{array}{l}\text { Pearson Correlation } \\
\text { Sig. (1-tailed) }\end{array}$ & $\begin{array}{c}-.705^{* *} \\
.000\end{array}$ & $\begin{array}{c}-.703^{* *} \\
.000\end{array}$ & $\begin{array}{l}-.440^{* *} \\
.000\end{array}$ & $\begin{array}{l}.607^{* *} \\
.000\end{array}$ & $\begin{array}{l}.609^{* *} \\
.000\end{array}$ & $\begin{array}{l}.010 \\
.376\end{array}$ & 1.000 & & \\
\hline FOREX/S ${ }_{i t-1}$ & $\begin{array}{l}\text { Pearson Correlation } \\
\text { Sig. (1-tailed) }\end{array}$ & $\begin{array}{l}-.451^{* *} \\
.000\end{array}$ & $\begin{array}{c}-.450^{* *} \\
.000\end{array}$ & $\begin{array}{l}-.193^{* *} \\
.000\end{array}$ & $\begin{array}{l}.676^{* *} \\
.000\end{array}$ & $\begin{array}{l}.677^{* *} \\
.000\end{array}$ & $\begin{array}{l}.028 \\
.184\end{array}$ & $\begin{array}{l}.189^{* *} \\
.000\end{array}$ & 1.000 & \\
\hline PENADJ $/ S_{i t-1}$ & $\begin{array}{l}\text { Pearson Correlation } \\
\text { Sig. (1-tailed) }\end{array}$ & $\begin{array}{l}.004 \\
.454\end{array}$ & $\begin{array}{l}.022 \\
.239\end{array}$ & $\begin{array}{r}-.033 \\
.142\end{array}$ & $\begin{array}{l}.064^{*} \\
.018\end{array}$ & $\begin{array}{l}.002 \\
.474\end{array}$ & $\begin{array}{l}.003 \\
.462\end{array}$ & $\begin{array}{l}-.002 \\
.476\end{array}$ & $\begin{array}{l}.002 \\
.472\end{array}$ & 1.000 \\
\hline
\end{tabular}

**. Correlation is significant at the 0.01 level (1-tailed).

*. Correlation is significant at the 0.05 level (1-tailed).

a. Listwise $\mathrm{N}=1074$ 
Panel C: Variables used in Valuation regressions testing the Value Relevance of OCI and components

\begin{tabular}{|c|c|c|c|c|c|c|c|c|c|c|c|}
\hline \multicolumn{2}{|c|}{ Correlations $^{\mathrm{a}}$} & \multirow{2}{*}{$\frac{P / S_{i t}}{1.000}$} & \multirow[t]{2}{*}{$B V E / S_{i t}$} & \multirow[t]{2}{*}{$N I / S_{i t}$} & \multirow[t]{2}{*}{$O C I / S_{1530 i t}$} & \multirow[t]{2}{*}{$O C I / S_{130 i t}$} & \multirow[t]{2}{*}{ HEDGE/S ${ }_{i t}$} & \multirow[t]{2}{*}{$S E C / S_{i t}$} & \multirow[t]{2}{*}{ FOREX/S $S_{\text {it }}$} & \multirow[t]{2}{*}{ PENADJ/S $_{\text {it }}$} & \multirow[t]{2}{*}{ AbnEarn $_{\text {it }}$} \\
\hline$P / S_{i t}$ & $\begin{array}{l}\text { Pearson Correlation } \\
\text { Sig. (1-tailed) }\end{array}$ & & & & & & & & & & \\
\hline$B V E / S_{i t}$ & $\begin{array}{l}\text { Pearson Correlation } \\
\text { Sig. (1-tailed) }\end{array}$ & $\begin{array}{l}.895^{* *} \\
.000\end{array}$ & 1.000 & & & & & & & & \\
\hline$N I / S_{i t}$ & $\begin{array}{l}\text { Pearson Correlation } \\
\text { Sig. (1-tailed) }\end{array}$ & $\begin{array}{l}.504^{* *} \\
.000\end{array}$ & $\begin{array}{l}.383^{* *} \\
.000\end{array}$ & 1.000 & & & & & & & \\
\hline$O C I / S_{1530 i t}$ & $\begin{array}{l}\text { Pearson Correlation } \\
\text { Sig. (1-tailed) }\end{array}$ & $\begin{array}{l}.373^{* *} \\
.000 \\
\end{array}$ & $\begin{array}{l}.465^{* *} \\
.000 \\
\end{array}$ & $\begin{array}{l}-.211^{* *} \\
.000 \\
\end{array}$ & 1.000 & & & & & & \\
\hline$O C I / S_{130 i t}$ & $\begin{array}{l}\text { Pearson Correlation } \\
\text { Sig. (1-tailed) }\end{array}$ & $\begin{array}{l}.375^{* *} \\
.000 \\
\end{array}$ & $\begin{array}{l}.466^{* *} \\
.000 \\
\end{array}$ & $\begin{array}{c}-.211^{* *} \\
.000 \\
\end{array}$ & $\begin{array}{l}.999^{* *} \\
.000 \\
\end{array}$ & 1.000 & & & & & \\
\hline$H E D G E / S_{i t}$ & $\begin{array}{l}\text { Pearson Correlation } \\
\text { Sig. (1-tailed) }\end{array}$ & $\begin{array}{l}.002 \\
.475\end{array}$ & $\begin{array}{l}.013 \\
.316\end{array}$ & $\begin{array}{l}.033 \\
.105\end{array}$ & $\begin{array}{l}.160^{* *} \\
.000\end{array}$ & $\begin{array}{l}.161^{* *} \\
.000\end{array}$ & 1.000 & & & & \\
\hline$S E C / S_{i t}$ & $\begin{array}{l}\text { Pearson Correlation } \\
\text { Sig. (1-tailed) }\end{array}$ & $\begin{array}{l}.364^{* *} \\
.000 \\
\end{array}$ & $\begin{array}{l}.458^{* *} \\
.000 \\
\end{array}$ & $\begin{array}{l}-.269^{* *} \\
.000 \\
\end{array}$ & $\begin{array}{l}.958^{* *} \\
.000 \\
\end{array}$ & $\begin{array}{l}.958^{* *} \\
.000 \\
\end{array}$ & $\begin{array}{c}-.018 \\
.250 \\
\end{array}$ & 1.000 & & & \\
\hline FOREX/S ${ }_{i t}$ & $\begin{array}{l}\text { Pearson Correlation } \\
\text { Sig. (1-tailed) }\end{array}$ & $\begin{array}{l}.154^{* *} \\
.000\end{array}$ & $\begin{array}{l}.179^{* *} \\
.000\end{array}$ & $\begin{array}{l}.201^{* *} \\
.000\end{array}$ & $\begin{array}{l}.335^{* *} \\
.000\end{array}$ & $\begin{array}{l}.334^{* *} \\
.000\end{array}$ & $\begin{array}{l}-.064^{* *} \\
.007 \\
\end{array}$ & $\begin{array}{l}.129^{* *} \\
.000 \\
\end{array}$ & 1.000 & & \\
\hline PENADJ/S & $\begin{array}{l}\text { Pearson Correlation } \\
\text { Sig. (1-tailed) }\end{array}$ & $\begin{array}{r}-.055^{*} \\
.017\end{array}$ & $\begin{array}{l}.012 \\
.330\end{array}$ & $\begin{array}{l}.008 \\
.380\end{array}$ & $\begin{array}{l}.037 \\
.078\end{array}$ & $\begin{array}{l}.004 \\
.437\end{array}$ & $\begin{array}{l}.009 \\
.365\end{array}$ & $\begin{array}{l}.001 \\
.479\end{array}$ & $\begin{array}{l}.020 \\
.218\end{array}$ & 1.000 & \\
\hline AbnEarn $_{\text {it }}$ & $\begin{array}{l}\text { Pearson Correlation } \\
\text { Sig. (1-tailed) }\end{array}$ & $\begin{array}{l}-.179^{* *} \\
.000\end{array}$ & $\begin{array}{l}-.325^{* *} \\
.000\end{array}$ & $\begin{array}{l}.475^{* *} \\
.000\end{array}$ & $\begin{array}{l}-.421^{* *} \\
.000\end{array}$ & $\begin{array}{l}-.421^{* *} \\
.000\end{array}$ & $\begin{array}{c}.004 \\
.443\end{array}$ & $\begin{array}{c}-.462^{* *} \\
.000\end{array}$ & $\begin{array}{l}.044^{*} \\
.046\end{array}$ & $\begin{array}{l}.008 \\
.383\end{array}$ & 1.000 \\
\hline
\end{tabular}

**. Correlation is significant at the 0.01 level (1-tailed).

*. Correlation is significant at the 0.05 level (1-tailed).

a. Listwise $\mathrm{N}=1464$ 
Panel D: Variables used in Returns regressions testing the Value Relevance of OCI and components

\begin{tabular}{|c|c|c|c|c|c|c|c|c|c|}
\hline Correlations $^{\mathrm{a}}$ & & $\operatorname{Ret}_{i t}$ & $N I_{i t}$ & $O C I_{1530 i t}$ & OCI $_{130 i t}$ & $H E D G E_{i t}$ & $S E C_{i t}$ & FOREX $_{i t}$ & PENADJ $_{i t}$ \\
\hline $\operatorname{Ret}_{i t}$ & $\begin{array}{l}\text { Pearson Correlation } \\
\text { Sig. (1-tailed) }\end{array}$ & 1.000 & & & & & & & \\
\hline$N I_{i t}$ & $\begin{array}{l}\text { Pearson Correlation } \\
\text { Sig. (1-tailed) }\end{array}$ & $\begin{array}{l}.158^{* *} \\
.000\end{array}$ & 1.000 & & & & & & \\
\hline$O C I_{1530 i t}$ & $\begin{array}{l}\text { Pearson Correlation } \\
\text { Sig. (1-tailed) }\end{array}$ & $\begin{array}{l}.163^{* *} \\
.000\end{array}$ & $\begin{array}{l}-.038 \\
.101\end{array}$ & 1.000 & & & & & \\
\hline$O C I_{130 i t}$ & $\begin{array}{l}\text { Pearson Correlation } \\
\text { Sig. (1-tailed) }\end{array}$ & $\begin{array}{l}.163^{* *} \\
.000\end{array}$ & $\begin{array}{r}-.053^{*} \\
.040\end{array}$ & $\begin{array}{l}.999^{* *} \\
.000\end{array}$ & 1.000 & & & & \\
\hline$H E D G E_{i t}$ & $\begin{array}{l}\text { Pearson Correlation } \\
\text { Sig. (1-tailed) }\end{array}$ & $\begin{array}{l}.100^{* *} \\
.000\end{array}$ & $\begin{array}{l}-.181^{* *} \\
.000\end{array}$ & $\begin{array}{l}.688^{* *} \\
.000\end{array}$ & $\begin{array}{l}.686^{* *} \\
.000\end{array}$ & 1.000 & & & \\
\hline$S E C_{i t}$ & $\begin{array}{l}\text { Pearson Correlation } \\
\text { Sig. (1-tailed) }\end{array}$ & $\begin{array}{l}.207^{* *} \\
.000\end{array}$ & $\begin{array}{l}.031 \\
.154\end{array}$ & $\begin{array}{l}.209^{* *} \\
.000\end{array}$ & $\begin{array}{l}.209^{* *} \\
.000\end{array}$ & $\begin{array}{l}-.003 \\
.458\end{array}$ & 1.000 & & \\
\hline$F_{O R E X_{i t}}$ & $\begin{array}{l}\text { Pearson Correlation } \\
\text { Sig. (1-tailed) }\end{array}$ & $\begin{array}{l}.070^{* *} \\
.010\end{array}$ & $\begin{array}{l}.116^{* *} \\
.000\end{array}$ & $\begin{array}{l}.686^{* *} \\
.000\end{array}$ & $\begin{array}{l}.686^{* *} \\
.000\end{array}$ & $\begin{array}{l}-.008 \\
.391\end{array}$ & $\begin{array}{l}-.013 \\
.337\end{array}$ & 1.000 & \\
\hline PENADJ ${ }_{i t}$ & $\begin{array}{l}\text { Pearson Correlation } \\
\text { Sig. (1-tailed) }\end{array}$ & $\begin{array}{l}.001 \\
.486\end{array}$ & $\begin{array}{l}-.262^{* *} \\
.000\end{array}$ & $\begin{array}{l}.019 \\
.269\end{array}$ & $\begin{array}{l}.036 \\
.116\end{array}$ & $\begin{array}{l}.037 \\
.108\end{array}$ & $\begin{array}{l}.002 \\
.469\end{array}$ & $\begin{array}{l}.010 \\
.372\end{array}$ & 1.000 \\
\hline
\end{tabular}

**. Correlation is significant at the 0.01 level (1-tailed).

*. Correlation is significant at the 0.05 level (1-tailed).

a. Listwise $\mathrm{N}=1097$ 
Panel E: Variables used in regressions testing the association between OCI and components and Analysts' Earnings Forecasts

\begin{tabular}{|c|c|c|c|c|c|c|c|c|c|c|c|c|}
\hline \multicolumn{2}{|l|}{ Correlations $^{\mathrm{a}}$} & IBESMean $_{i t}$ & IBESMed $_{i t}$ & $E P S_{i t}$ & $L n M V E_{i t-1}$ & $\operatorname{LnTV}_{\text {it }}$ & $\operatorname{LnFol}_{i t}$ & $O C I / S_{1530 i t}$ & $H^{H E D G E} / S_{i t}$ & $S E C / S_{i t}$ & FOREX/S ${ }_{i t}$ & PENADJ $/ S_{i t}$ \\
\hline IBESMean $_{\text {it }}$ & $\begin{array}{l}\text { Pearson Correlation } \\
\text { Sig. (1-tailed) }\end{array}$ & 1.000 & & & & & & & & & & \\
\hline IBESMed $_{i t}$ & $\begin{array}{l}\text { Pearson Correlation } \\
\text { Sig. (1-tailed) }\end{array}$ & $\begin{array}{l}.999^{* *} \\
.000\end{array}$ & 1.000 & & & & & & & & & \\
\hline$E P S_{i t}$ & $\begin{array}{l}\text { Pearson Correlation } \\
\text { Sig. (1-tailed) }\end{array}$ & $\begin{array}{l}.777^{* *} \\
.000\end{array}$ & $\begin{array}{l}.770^{* *} \\
.000\end{array}$ & 1.000 & & & & & & & & \\
\hline$L n M V E_{i t-1}$ & $\begin{array}{l}\text { Pearson Correlation } \\
\text { Sig. (1-tailed) }\end{array}$ & $\begin{array}{l}.545^{* *} \\
.000\end{array}$ & $\begin{array}{l}.540^{* *} \\
.000\end{array}$ & $\begin{array}{l}.433^{* *} \\
.000\end{array}$ & 1.000 & & & & & & & \\
\hline$L n T V_{i t}$ & $\begin{array}{l}\text { Pearson Correlation } \\
\text { Sig. (1-tailed) }\end{array}$ & $\begin{array}{l}.112^{* *} \\
.002 \\
\end{array}$ & $\begin{array}{l}.111^{* *} \\
.002 \\
\end{array}$ & $\begin{array}{l}.052 \\
.090 \\
\end{array}$ & $\begin{array}{l}.445^{* *} \\
.000 \\
\end{array}$ & 1.000 & & & & & & \\
\hline $\operatorname{LnFol}_{i t}$ & $\begin{array}{l}\text { Pearson Correlation } \\
\text { Sig. (1-tailed) }\end{array}$ & $\begin{array}{l}.259^{* *} \\
.000\end{array}$ & $\begin{array}{l}.258^{* *} \\
.000\end{array}$ & $\begin{array}{l}.208^{* *} \\
.000\end{array}$ & $\begin{array}{l}.422^{* *} \\
.000\end{array}$ & $\begin{array}{l}.343^{* *} \\
.000\end{array}$ & 1.000 & & & & & \\
\hline$O C I / S_{1530 i t}$ & $\begin{array}{l}\text { Pearson Correlation } \\
\text { Sig. (1-tailed) }\end{array}$ & $\begin{array}{l}.019 \\
.308\end{array}$ & $\begin{array}{l}.016 \\
.340\end{array}$ & $\begin{array}{c}- \\
.081^{*} \\
.018\end{array}$ & $\begin{array}{l}-.068^{*} \\
.038\end{array}$ & $\begin{array}{l}.063^{*} \\
.050\end{array}$ & $\begin{array}{l}.037 \\
.171\end{array}$ & 1.000 & & & & \\
\hline$H E D G E / S_{i t}$ & $\begin{array}{l}\text { Pearson Correlation } \\
\text { Sig. (1-tailed) }\end{array}$ & $\begin{array}{l}.052 \\
.088\end{array}$ & $\begin{array}{l}.051 \\
.092\end{array}$ & $\begin{array}{c}- \\
.083^{*} \\
.016\end{array}$ & $\begin{array}{l}-.039 \\
.157\end{array}$ & $\begin{array}{l}.113^{* *} \\
.002\end{array}$ & $\begin{array}{l}.026 \\
.252\end{array}$ & $\begin{array}{l}.680^{* *} \\
.000\end{array}$ & 1.000 & & & \\
\hline$S E C / S_{i t}$ & $\begin{array}{l}\text { Pearson Correlation } \\
\text { Sig. (1-tailed) } \\
\end{array}$ & $\begin{array}{c}-.149^{* *} \\
.000 \\
\end{array}$ & $\begin{array}{c}-.155^{* *} \\
.000 \\
\end{array}$ & \begin{tabular}{|c|}
- \\
$.066^{*}$ \\
.043 \\
\end{tabular} & $\begin{array}{c}-.123^{* *} \\
.001 \\
\end{array}$ & $\begin{array}{l}.012 \\
.378 \\
\end{array}$ & $\begin{array}{l}.021 \\
.292 \\
\end{array}$ & $\begin{array}{l}.240^{* *} \\
.000 \\
\end{array}$ & $\begin{array}{l}-.016 \\
.341 \\
\end{array}$ & 1.000 & & \\
\hline FOREX/S ${ }_{i t}$ & $\begin{array}{l}\text { Pearson Correlation } \\
\text { Sig. (1-tailed) }\end{array}$ & $\begin{array}{l}.045 \\
.119\end{array}$ & $\begin{array}{l}.044 \\
.125\end{array}$ & $\begin{array}{l}.000 \\
.492\end{array}$ & $\begin{array}{l}.000 \\
.495\end{array}$ & $\begin{array}{l}-.029 \\
.224\end{array}$ & $\begin{array}{l}.017 \\
.334\end{array}$ & $\begin{array}{l}.632^{* *} \\
.000\end{array}$ & $\begin{array}{l}-.035 \\
.185\end{array}$ & $\begin{array}{l}-.113^{* *} \\
.002\end{array}$ & 1.000 & \\
\hline 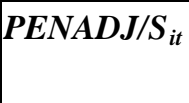 & $\begin{array}{l}\text { Pearson Correlation } \\
\text { Sig. (1-tailed) }\end{array}$ & $\begin{array}{l}-.013 \\
.367\end{array}$ & $\begin{array}{l}-.014 \\
.362\end{array}$ & $\begin{array}{l}.080^{*} \\
.019\end{array}$ & $\begin{array}{l}.000 \\
.496\end{array}$ & $\begin{array}{l}-.007 \\
.428\end{array}$ & $\begin{array}{l}-.003 \\
.471\end{array}$ & $\begin{array}{l}.012 \\
.380\end{array}$ & $\begin{array}{l}.069^{*} \\
.036\end{array}$ & $\begin{array}{l}-.002 \\
.477\end{array}$ & $\begin{array}{r}-.053 \\
.085\end{array}$ & 1.000 \\
\hline
\end{tabular}


**. Correlation is significant at the 0.01 level (1-tailed). *. Correlation is significant at the 0.05 level (1-tailed). a. Listwise N=675

Panel F: Variables used in regressions testing the association between OCI and components and Analysts' Earnings Forecast Errors

\begin{tabular}{|c|c|c|c|c|c|c|c|c|c|c|c|c|}
\hline Correlations $^{\mathrm{a}}$ & & $F E R R_{i t}$ & $M N M D_{i t}$ & Accruals $/ S_{i t}$ & $L n M V E_{i t}$ & $\operatorname{LnTV}_{\text {it }}$ & LnFol $_{\text {it }}$ & $O C I / S_{1530 i t}$ & HEDGE/S & $S E C / S_{i t}$ & FOREX/S & PENADJ/S ${ }_{i t}$ \\
\hline$F E R R_{i t}$ & $\begin{array}{l}\text { Pearson Correlation } \\
\text { Sig. (1-tailed) }\end{array}$ & 1.000 & & & & & & & & & & \\
\hline$M N M D_{i t}$ & $\begin{array}{l}\text { Pearson Correlation } \\
\text { Sig. (1-tailed) }\end{array}$ & $\begin{array}{r}.207^{* *} \\
.000\end{array}$ & 1.000 & & & & & & & & & \\
\hline Accruals/S $S_{i t}$ & $\begin{array}{l}\text { Pearson Correlation } \\
\text { Sig. (1-tailed) }\end{array}$ & $\begin{array}{r}-.239^{* *} \\
.000\end{array}$ & $\begin{array}{l}.001 \\
.493\end{array}$ & 1.000 & & & & & & & & \\
\hline$L n M V E_{i t-1}$ & $\begin{array}{l}\text { Pearson Correlation } \\
\text { Sig. (1-tailed) }\end{array}$ & $\begin{array}{l}.061 \\
.056\end{array}$ & $\begin{array}{l}.035 \\
.185\end{array}$ & $\begin{array}{r}.135^{* *} \\
.000\end{array}$ & 1.000 & & & & & & & \\
\hline $\operatorname{LnTV} V_{\text {it }}$ & $\begin{array}{l}\text { Pearson Correlation } \\
\text { Sig. (1-tailed) }\end{array}$ & $\begin{array}{r}-.049 \\
.102\end{array}$ & $\begin{array}{r}-.029 \\
.228\end{array}$ & $\begin{array}{r}-.021 \\
.296\end{array}$ & $\begin{array}{r}.445^{* *} \\
.000\end{array}$ & 1.000 & & & & & & \\
\hline LnFol $_{i t}$ & $\begin{array}{l}\text { Pearson Correlation } \\
\text { Sig. (1-tailed) }\end{array}$ & $\begin{array}{l}.051 \\
.093\end{array}$ & $\begin{array}{r}-.038 \\
.161\end{array}$ & $\begin{array}{r}-.005 \\
.451\end{array}$ & $\begin{array}{c}.422^{* *} \\
.000\end{array}$ & $\begin{array}{r}.343^{* *} \\
.000\end{array}$ & 1.000 & & & & & \\
\hline$O C I / S_{1530 i t}$ & $\begin{array}{l}\text { Pearson Correlation } \\
\text { Sig. (1-tailed) }\end{array}$ & $\begin{array}{r}-.162^{* *} \\
.000\end{array}$ & $\begin{array}{l}.009 \\
.410\end{array}$ & $\begin{array}{r}.118^{* *} \\
.001\end{array}$ & $\begin{array}{r}-.068^{*} \\
.038\end{array}$ & $\begin{array}{c}.063^{*} \\
.050\end{array}$ & $\begin{array}{l}.037 \\
.171\end{array}$ & 1.000 & & & & \\
\hline$H E D G E / S_{i t}$ & $\begin{array}{l}\text { Pearson Correlation } \\
\text { Sig. (1-tailed) }\end{array}$ & $\begin{array}{r}-.228^{* *} \\
.000 \\
\end{array}$ & $\begin{array}{l}.000 \\
.499 \\
\end{array}$ & $\begin{array}{r}.055 \\
.078 \\
\end{array}$ & $\begin{array}{r}-.039 \\
.157 \\
\end{array}$ & $\begin{array}{r}.113^{* *} \\
.002 \\
\end{array}$ & $\begin{array}{l}.026 \\
.252 \\
\end{array}$ & $\begin{array}{c}.680^{* *} \\
.000 \\
\end{array}$ & 1.000 & & & \\
\hline$S E C / S_{i t}$ & $\begin{array}{l}\text { Pearson Correlation } \\
\text { Sig. (1-tailed) }\end{array}$ & $\begin{array}{r}-.005 \\
.448\end{array}$ & $\begin{array}{r}.013 \\
.373\end{array}$ & $\begin{array}{r}-.101^{* *} \\
.004\end{array}$ & $\begin{array}{r}-.123^{* *} \\
.001\end{array}$ & $\begin{array}{l}.012 \\
.378\end{array}$ & $\begin{array}{l}.021 \\
.292\end{array}$ & $\begin{array}{r}.240^{* *} \\
.000\end{array}$ & $\begin{array}{r}-.016 \\
.341\end{array}$ & 1.000 & & \\
\hline$F O R E X / S_{i t}$ & $\begin{array}{l}\text { Pearson Correlation } \\
\text { Sig. (1-tailed) }\end{array}$ & $\begin{array}{l}.001 \\
.485 \\
\end{array}$ & $\begin{array}{l}.007 \\
.430\end{array}$ & $\begin{array}{r}.162^{* *} \\
.000\end{array}$ & $\begin{array}{l}.000 \\
.495\end{array}$ & $\begin{array}{r}-.029 \\
.224\end{array}$ & $\begin{array}{l}.017 \\
.334\end{array}$ & $\begin{array}{r}.632^{* *} \\
.000\end{array}$ & $\begin{array}{r}-.035 \\
.185\end{array}$ & $\begin{array}{r}-.113^{* *} \\
.002\end{array}$ & 1.000 & \\
\hline$P E N A D J / S_{i t}$ & Pearson Correlation & $.152^{* *}$ & .008 & -.062 & .000 & -.007 & -.003 & .012 & $.069^{*}$ & -.002 & -.053 & 1.000 \\
\hline
\end{tabular}




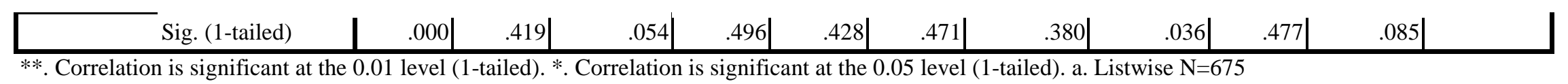


The results of the various regression models described in chapter 5 are reported in section 6.2. Results of additional regressions to test the sensitivity of the results are then reported in section 6.3.

\subsection{Results of regression analyses}

The following subsections report the results of regressions testing (6.2.1) the ability of OCI and its components to forecast future abnormal earnings, (6.2.2) the predictability of OCI and its components, (6.2.3) the value relevance of OCI and its components, as indicated by their association with stock prices, (6.2.4) the value relevance of OCI and its components, as indicated by their association with stock returns, (6.2.5) the association of OCI and its components with analysts' earnings forecasts, and (6.2.6) the association of OCI and its components with analysts' earnings forecast errors.

6.2.1 Regressions to test the ability of OCI and its components to forecast future abnormal earnings

Following Ohlson (1999), I test the ability of OCI and its components to forecast future abnormal returns using the following models:

$$
\begin{aligned}
& \text { AbnEarn } / S_{i t}=\alpha_{0}+\alpha_{1} \text { AbnEarn } / S_{\text {it- } 1}+\alpha_{2} O C I / S_{1530 ~ i t-1}+\varepsilon_{i t} \\
& \text { AbnEarn } / S_{i t}=\alpha_{0}+\alpha_{1} A b n E a r n / S_{i t-1}+\alpha_{2} O C I / S_{130 i t-1}+\varepsilon_{i t} \\
& \text { AbnEarn } / S_{i t}=\alpha_{0}+\alpha_{1} A b n E a r n / S_{i t-1}+\alpha_{2} H E D G E / S_{i t-1}+\alpha_{3} S E C / S_{i t-1}+\alpha_{4} \text { FOREX/S } S_{i t-1}+\varepsilon_{i t}[1 \mathrm{c}] \\
& \text { AbnEarn } / S_{i t}=\alpha_{0}+\alpha_{1} \text { AbnEarn } / S_{i t-1}+\alpha_{2} \text { HEDGE } / S_{i t-1}+\alpha_{3} \text { SEC } / S_{i t-1}+\alpha_{4} \text { FOREX/S } S_{i t-1}+ \\
& \alpha_{5} P E N A D J / S_{i t-1}+\varepsilon_{i t}
\end{aligned}
$$

Where variables are as defined earlier.

Ohlson's (1999) prediction is that transitory earnings should not have any ability to forecast future abnormal earnings. Table 6.3 reports the results for the four regression models. The adjusted r-squareds for models 2a through 2d range between 11.6 per cent and 16.3 per cent, indicating that the model fit is modest at best. 
Table 6-3: Regressions to test the ability of OCI and its components to forecast future abnormal earnings

\begin{tabular}{|c|c|c|c|c|c|}
\hline Dependent Variable & \multicolumn{5}{|c|}{ AbnEarn $_{\text {it }}$} \\
\hline Independent Variables & Model 1a & Model 1b & Model 1c & Model 1d & Model 1e \\
\hline Intercept & $\begin{array}{l}-.378 \\
{[t=-6.367} \\
p=.000]\end{array}$ & $\begin{array}{l}-.379 \\
{[t=-6.360} \\
p=.000]\end{array}$ & $\begin{array}{l}-.390 \\
{[t=-6.674} \\
p=.000]\end{array}$ & $\begin{array}{l}-.398 \\
{[t=-6.854} \\
p=.000]\end{array}$ & $\begin{array}{l}-.504 \\
{[t=-8.100} \\
p=.000]\end{array}$ \\
\hline AbnEarn $/ S_{i t-1}$ & $\begin{array}{l}.261 \\
{[t=11.094} \\
p=.000]\end{array}$ & $\begin{array}{l}.259 \\
{[t=10.990} \\
p=.000]\end{array}$ & $\begin{array}{l}.243 \\
{[t=9.994} \\
p=.000]\end{array}$ & $\begin{array}{l}.240 \\
{[t=9.908} \\
p=.000]\end{array}$ & \\
\hline AEDiffOCI $_{i t-1}$ & & & & & $\begin{array}{l}-.011 \\
{[t=-2.069} \\
p=.039]\end{array}$ \\
\hline$O C I_{1530} / S_{i t-1}$ & $\begin{array}{l}.385 \\
{[t=8.386} \\
p=.000]\end{array}$ & & & & \\
\hline$\overline{O C I_{130} / S_{i t-1}}$ & & $\begin{array}{l}.372 \\
{[t=8.110} \\
p=.000]\end{array}$ & & & \\
\hline$H E D G E / S_{i t-1}$ & & & $\begin{array}{l}.775 \\
{[t=10.048} \\
p=.000]\end{array}$ & $\begin{array}{l}.775 \\
{[t=10.119} \\
p=.000]\end{array}$ & \\
\hline$S E C / S_{i t-1}$ & & & $\begin{array}{l}.368 \\
{[t=3.801} \\
p=.001]\end{array}$ & $\begin{array}{l}.362 \\
{[t=3.757} \\
p=.000]\end{array}$ & \\
\hline FOREX/S $S_{i t-1}$ & & & $\begin{array}{l}.085 \\
{[t=1.173} \\
p=.241]\end{array}$ & $\begin{array}{l}.084 \\
{[t=1.172} \\
p=.420]\end{array}$ & \\
\hline$P E N A D J / S_{i t-1}$ & & & & $\begin{array}{l}-2.557 \\
{[t=-3.783} \\
p=.000]\end{array}$ & \\
\hline $\begin{array}{l}\text { No. of observations } \\
\text { F-Value } \\
\text { Adjusted } R^{2}\end{array}$ & $\begin{array}{l}1074 \\
73.543 \\
.119\end{array}$ & $\begin{array}{l}1074 \\
71.113 \\
.116\end{array}$ & $\begin{array}{l}1074 \\
49.356 \\
.153\end{array}$ & $\begin{array}{l}1074 \\
42.838 \\
.163\end{array}$ & $\begin{array}{l}1074 \\
4.281 \\
.004\end{array}$ \\
\hline
\end{tabular}

Consistent with Ohlson (1999), the coefficient on lagged abnormal returns is positive and significant at the $\mathrm{p}<0.01$ level, suggesting that prior abnormal returns are an indicator of abnormal returns in the future. However, contrary to Ohlson's (1999) prediction that OCI is transitory earnings, the coefficient on both $\mathrm{OCI}_{1530}$ and on $\mathrm{OCI}_{130}$ is positive, and significant at a $\mathrm{P}<.01$ level. As for individual components of $\mathrm{OCI}_{1530}$, HEDGE and SEC are positively and significantly associated with future abnormal earnings, whereas FOREX is not. PENADJ is negatively and significantly associated with future earnings. These results make sense conceptually. An unrealized gain (loss) related to a cash flow hedge or on an available for sale 
security would increase future earnings when it is realized (assuming recycling of OCI through net income is permitted). On the other hand, a higher pension adjustment amount would represent potentially higher pension expense in the future, thereby causing earnings to decline.

To test whether the coefficients on abnormal earnings and $\mathrm{OCI}_{1530}$ are statistically equal to zero, I carry out an incremental F-test, using model 1a as the unconstrained model, and model 1e as the constrained model. The incremental F-statistic is calculated as $F_{J, N-K-1}=\frac{\left(R_{U}^{2}-R_{C}^{2}\right) *(N-K-J)}{\left(1-R_{U}^{2}\right) * J}$, where the number of constraints, J=1, N=1074, K=2, $R_{U}^{2}=$ .119 and $R_{C}^{2}=.004$. Accordingly, the F-statistic equals $139.80^{28}$, implying a t-statistic of 11.823 , and is significant at a $\mathrm{p}<.01$ level. Thus, we reject the hypothesis that the coefficients on abnormal earnings and $\mathrm{OCI}_{1530}$ are equal to zero, implying that contrary to Ohlson’ (1999) prediction, OCI does possess forecasting relevance.

\subsubsection{Regressions to test predictability of OCI}

Following Ohlson (1999), I estimate the following regressions to test predictability of OCI. Ohlson suggested that transitory earnings items are unpredictable. If OCI is indeed transitory, we would expect to find that the regression coefficients would be insignificant.

$$
\begin{aligned}
& \mathrm{OCI}_{1530} / S_{i t}=\beta_{0}+\beta_{1} A \text { AbnEarn } / S_{i t-1}+\beta_{2} O C I_{1530} / S_{i t-1}+\varepsilon_{i t} \\
& \mathrm{OCI}_{1530} / S_{i t}=\beta_{0}+\beta_{1} \mathrm{AbnEarn} / S_{i t-1}+\beta_{2} \mathrm{HEDGE} / S_{i t-1}+\beta_{3} S E C / S_{i t-1}+\beta_{4} F O R E X / S_{i t-1}+\varepsilon_{i t}[2 \mathrm{~b}] \\
& \mathrm{OCI}_{130} / S_{i t}=\beta_{0}+\beta_{1} A b n E a r n / S_{i t-1}+\beta_{2} O C I_{130} / S_{i t-1}+\varepsilon_{i t} \\
& \mathrm{OCI}_{130} / S_{i t}=\quad \beta_{0}+\beta_{1} \text { AbnEarn } / S_{i t-1}+\beta_{2} H_{E D G E} / S_{i t-1}+\beta_{3} S E C / S_{i t-1}+\beta_{4} \text { FOREX } / S_{i t-1}+\beta_{5} \text { PENADJ } / S_{i t-1} \\
& +\varepsilon_{i t}
\end{aligned}
$$

where subscripts $i$ and $t$ denote the firm $i$ and year $t$ respectively, and the variables are as defined earlier.

$$
\begin{aligned}
& { }^{28} F_{J, N-K-1}=\frac{\left(R_{U}^{2}-R_{C}^{2}\right) *(N-K-J)}{\left(1-R_{U}^{2}\right) * J}=\frac{(.119-.004) *(1074-2-1)}{(1-.119) * 1}=139.80 \\
& \text { t-statistic }=\sqrt{139.80}=11.823
\end{aligned}
$$


The results of the tests are reported in Table 6.4. The adjusted r-squareds for models 2a through $2 \mathrm{~d}$ range between 52.2 per cent and 63.5 per cent, indicating a fairly good model fit.

Table 6-4: Regressions to test predictability of OCI

\begin{tabular}{|c|c|c|c|c|}
\hline Dependent Variable & \multicolumn{2}{|c|}{$O C I_{1530 i t}$} & \multicolumn{2}{|c|}{$\mathrm{OCI}_{130 \mathrm{it}}$} \\
\hline Independent Variables & Model 2a & Model 2b & Model 2c & Model 2d \\
\hline Intercept & $\begin{array}{l}.018 \\
{[t=.466} \\
p=.641]\end{array}$ & $\begin{array}{l}.024 \\
{[t=-.718} \\
p=.473]\end{array}$ & $\begin{array}{l}.009 \\
{[\mathrm{t}=.238} \\
\mathrm{p}=.812]\end{array}$ & $\begin{array}{l}. .029 \\
{[t=-.861} \\
p=.389]\end{array}$ \\
\hline AbnEarn $_{\text {it }-1}$ & $\begin{array}{l}.099 \\
{[t=6.521} \\
p=.000]\end{array}$ & $\begin{array}{l}.020 \\
{[t=1.395} \\
p=.163]\end{array}$ & $\begin{array}{l}.098 \\
{[t=6.396} \\
p=.000]\end{array}$ & $\begin{array}{l}.019 \\
{[t=1.362} \\
p=.174]\end{array}$ \\
\hline $\mathrm{OCI}_{1530 i t-1}$ & $\begin{array}{l}-.885 \\
{[t=-29.881} \\
p=.000]\end{array}$ & & & \\
\hline$O C I_{130 i t-1}$ & & & $\begin{array}{l}-.880 \\
{[\mathrm{t}=-29.438} \\
\mathrm{p}=.000]\end{array}$ & \\
\hline$H E D G E_{i t-1}$ & & $\begin{array}{l}-.443 \\
{[t=-9.908} \\
p=.000]\end{array}$ & & $\begin{array}{l}-.445 \\
{[t=-9.872} \\
p=.000]\end{array}$ \\
\hline$S E C_{i t-1}$ & & $\begin{array}{l}-1.703 \\
{[t=-30.331} \\
p=.000]\end{array}$ & & $\begin{array}{l}-1.704 \\
{[t=-30.093} \\
p=.000]\end{array}$ \\
\hline$F_{O R E X_{i t-1}}$ & & $\begin{array}{l}-.736 \\
{[t=-17.517} \\
p=.000]\end{array}$ & & $\begin{array}{l}-.735 \\
{[t=-17.356} \\
p=.000]\end{array}$ \\
\hline$P_{\text {PENADJ }}$ it-1 & & & & $\begin{array}{l}.486 \\
{[t=1.222} \\
p=.222]\end{array}$ \\
\hline $\begin{array}{l}\text { No. of observations } \\
\text { F-Value } \\
\text { Adjusted } R^{2}\end{array}$ & $\begin{array}{l}1074 \\
604.171 \\
.529\end{array}$ & $\begin{array}{l}1074 \\
466.963 \\
.635\end{array}$ & $\begin{array}{l}1074 \\
586.716 \\
.522 \\
\end{array}$ & $\begin{array}{l}1074 \\
367.820 \\
.631 \\
\end{array}$ \\
\hline
\end{tabular}

Models $2 \mathrm{a}$ and $2 \mathrm{c}$ regress $\mathrm{OCI}_{1530}$ and $\mathrm{OCI}_{130}$ on lagged abnormal earnings and lagged $\mathrm{OCI}_{1530}$ and $\mathrm{OCI}_{130}$ respectively. In both cases, the predictor variables turn out to be significant at a $\mathrm{p}<.01$ level. The coefficient on $\mathrm{OCI}_{1530}$ and $\mathrm{OCI}_{130}$ is negative, and close to minus- 1 . This is consistent with Ohlson's (1999) description of OCI being transitory, in the sense that aggregate OCI values appear to reverse in the following year. The coefficient on lagged abnormal earnings is positive, and although it is statistically significant, it is closer to zero than to one. This is qualitatively consistent with Ohlson’s (1999) prediction. 
Models $2 \mathrm{~b}$ and $2 \mathrm{~d}$ regress $\mathrm{OCI}_{1530}$ and $\mathrm{OCI}_{130}$ respectively on their lagged components, as well as lagged abnormal earnings. In this case, the coefficient on lagged abnormal earnings is insignificant, confirming Ohlson's (1999) prediction that the coefficient would be statistically equal to zero. Similarly, the coefficients on HEDGE and FOREX, while statistically significant, have absolute values less than one, implying low persistence. Smith and Jones (2011) also report negative persistence for OCI items.

However, contrary to Ohlson's (1999) prediction, the coefficient on SEC has an absolute value greater than one. This result is puzzling, but resonates with Chambers et al's (2007) equally puzzling finding of the coefficient on the same variable (called MKTADJ by the authors) in a valuation regression being greater than even that on net income. Perhaps, there is at least one component of OCI, namely unrealized gains and losses on available for sale securities, SEC, which is (negatively) persistent.

\subsubsection{Valuation (Level) Regressions to test value-relevance of OCI and components}

The results reported in the preceding two sections suggest that aggregate OCI as well as some of its components are both predictable and relevant for forecasting future abnormal earnings. Following Ohlson (1999), these results imply value relevance. To confirm these expectations, I test for value relevance of OCI and its components by running two sets of regressions: valuation (price-level) regressions and returns (price-change) regressions. In this section, I report the results for the following valuation regressions:

$$
\begin{aligned}
P / S_{i t} & =\gamma_{0}+\gamma_{1} B V E / S_{i t}+\gamma_{2} N I / S_{i t}+\gamma_{3} O^{O C I} I_{1530} / S_{i t}+\varepsilon_{i t}[3 \mathrm{a}] \\
P / S_{i t} & =\gamma_{0}+\gamma_{1} B V E / S_{i t}+\gamma_{2} N I / S_{i t}+\gamma_{3} O_{130} / S_{i t}+\varepsilon_{i t}[3 \mathrm{~b}] \\
P / S_{i t} & =\gamma_{0}+\gamma_{1} B V E / S_{i t}+\gamma_{2} N I / S_{i t}+\gamma_{3} H E D G E / S_{i t}+\gamma_{4} S E C / S_{i t}+\gamma_{5} F O R E X / S_{i t}+\varepsilon_{i t}[3 \mathrm{c}] \\
P / S_{i t} & =\gamma_{0}+\gamma_{1} B V E / S_{i t}+\gamma_{2} N I / S_{i t}+\gamma_{3} H E D G E / S_{i t}+\gamma_{4} S E C / S_{i t}+\gamma_{5} F O R E X / S_{i t}+\gamma_{6} P E N A D J / S_{i t}+\varepsilon_{i t}
\end{aligned}
$$

$P / S_{i t}=\gamma_{0}+\gamma_{1} B$ VE $/ S_{i t}+\gamma_{2}$ AbnEarn $_{i t}+\gamma_{3}$ OCI $_{1530} / S_{i t}+\varepsilon_{i t}[3 e]$

$P / S_{i t}=\gamma_{0}+\gamma_{1} B V E / S_{i t}+\gamma_{2}$ AEDiffOCI $_{i t}+\varepsilon_{i t}[3 f]$ 


$$
\begin{aligned}
& P / S_{i t}=\gamma_{0}+\gamma_{1} B_{V E} / S_{i t}+\gamma_{2} \text { AbnEarn }_{i t}+\gamma_{3} H E D G E / S_{i t}+\gamma_{4} S E C / S_{i t}+\gamma_{5} F_{O R E X / S_{i t}}+\gamma_{6}{\text { PENADJ } / S_{i t}}+ \\
& \varepsilon_{i t}[3 g]
\end{aligned}
$$

where subscripts $i$ and $t$ denote the firm $i$ and year $t$ respectively, and the variables are as defined earlier.

As reported in Table 6.5, based on the results of the valuation regressions, other comprehensive income is significantly associated with stock price. The t-statistic for $\mathrm{OCI}_{1530}$ as well as for $\mathrm{OCI}_{130}$ is considerably smaller than for book value per share and net income. However, the coefficients for book value, net income and OCI are all positive and significant at a $\mathrm{P}<.01$ level. The sign of the coefficient on the change in fair value of available for sale investments $(S E C / S)$ is positive and significant at the $\mathrm{P}<.01$ level. This result is consistent with the findings of Kanagaretnam et al. However, contrary to Kanagaretnam et al (2009), I find the sign of the coefficient on the change in cash flow hedges (HEDGE/S) to be positive, and only marginally significant at the $\mathrm{p}<.1$ level. Kanagaretnam et al had found the coefficient to be negative and non-significant, prompting the authors to test the interaction effect of losing versus winning hedge positions. Kanagaretnam et al used an indicator variable GAIN for winning hedge positions, and an interaction variable HEDGE_GAIN in an expanded model. They found the coefficient on the change in cash flow hedges to be significant, albeit still negative in sign. The coefficient on the interaction variable was positive, but only marginally significant. The authors concluded that "losing hedged positions can also be viewed as a positive signal by the market since it indicates that the firm actively manages its risk” (page 359). My finding of a positive, though marginally significant, coefficient on changes in the cash flow hedges could be interpreted to mean that the market does distinguish effective risk management from ineffective efforts, and prices them accordingly. 
Table 6-5: Valuation (Level) Regressions to test value-relevance of OCI and components

\begin{tabular}{|c|c|c|c|c|c|c|c|}
\hline Dependent & \multicolumn{7}{|c|}{$P / S_{i t}$} \\
\hline $\begin{array}{l}\text { Independent } \\
\text { Variables }\end{array}$ & Model 3a & Model 3b & Model 3c & Model 3d & Model 3e & Model 3f & Model 3g \\
\hline Intercept & $\begin{array}{l}8.941 \\
{[t=28.411 ;} \\
p=.000]\end{array}$ & $\begin{array}{l}8.934 \\
{[t=28.369 ;} \\
p=.000]\end{array}$ & $\begin{array}{l}8.874 \\
{[t=28.393 ;} \\
p=.000]\end{array}$ & $\begin{array}{l}8.823 \\
{[t=28.366 ;} \\
p=.000]\end{array}$ & $\begin{array}{l}9.056 \\
{[t=27.303 ;} \\
p=.000]\end{array}$ & $\begin{array}{l}8.866 \\
{[t=26.935 ;} \\
p=.000]\end{array}$ & $\begin{array}{l}8.976 \\
{[t=27.174 ;} \\
p=.000]\end{array}$ \\
\hline$B V E / S_{i t}$ & $\begin{array}{l}.680 \\
{[t=54.259 ;} \\
p=.000]\end{array}$ & $\begin{array}{l}.682 \\
{[t=54.384 ;} \\
p=.000]\end{array}$ & $\begin{array}{l}.669 \\
{[t=52.453 ;} \\
p=.000]\end{array}$ & $\begin{array}{l}.669 \\
{[t=52.697 ;} \\
p=.000]\end{array}$ & $\begin{array}{l}.810 \\
{[t=72.942 ;} \\
p=.000]\end{array}$ & $\begin{array}{l}.819 \\
{[t=75.189 ;} \\
p=.000]\end{array}$ & $\begin{array}{l}.812 \\
{[t=73.097 ;} \\
p=.000]\end{array}$ \\
\hline$N I / S_{i t}$ & $\begin{array}{l}1.618 \\
{[t=16.157 ;} \\
p=.000]\end{array}$ & $\begin{array}{l}1.610 \\
{[t=16.065 ;} \\
p=.000]\end{array}$ & $\begin{array}{l}1.797 \\
{[t=16.902} \\
p=.000]\end{array}$ & $\begin{array}{l}1.794 \\
{[t=16.975} \\
p=.000]\end{array}$ & & & \\
\hline AbnEarn $_{\text {it }}$ & & & & & $\begin{array}{l}.626 \\
{[t=9.598 ;} \\
p=.000]\end{array}$ & & $\begin{array}{l}.642 \\
{[t=9.622 ;} \\
p=.000]\end{array}$ \\
\hline AEDiffOCI $_{i t}$ & & & & & & $\begin{array}{l}.456 \\
{[t=9.761 ;} \\
p=.000]\end{array}$ & \\
\hline OCI $/ S_{1530 i t}$ & $\begin{array}{l}.417 \\
{[t=3.802 ;} \\
p=.000]\end{array}$ & & & & $\begin{array}{l}.096 \\
{[\mathrm{t}=-.899} \\
\mathrm{p}=.369]\end{array}$ & & \\
\hline OCI $/ S_{130 i t}$ & & $\begin{array}{l}.397 \\
{[t=3.619 ;} \\
p=.000]\end{array}$ & & & & & \\
\hline$H E D G E / S_{i t}$ & & & $\begin{array}{l}.741 \\
{[t=1.675} \\
p=.094]\end{array}$ & $\begin{array}{l}.727 \\
{[t=1.652 ;} \\
p=.099]\end{array}$ & & & $\begin{array}{l}.509 \\
{[t=1.090} \\
p=.276]\end{array}$ \\
\hline$S E C / S_{i t}$ & & & $\begin{array}{l}.661 \\
{[t=5.368} \\
p=.000]\end{array}$ & $\begin{array}{l}.662 \\
{[t=5.408} \\
p=.000]\end{array}$ & & & $\begin{array}{l}-.067 \\
{[t=-.575 ;} \\
p=.566]\end{array}$ \\
\hline$F O R E X / S_{i t}$ & & & $\begin{array}{l}-1.463 \\
{[t=-3.756 ;} \\
p=.000]\end{array}$ & $\begin{array}{l}-1.427 \\
{[t=-3.683 ;} \\
p=.000]\end{array}$ & & & $\begin{array}{l}-.613 \\
{[\mathrm{t}=--1.508 ;} \\
\mathrm{p}=.132]\end{array}$ \\
\hline PENADJ/S ${ }_{i t}$ & & & & $\begin{array}{l}-10.615 \\
{[t=-4.150} \\
p=.000]\end{array}$ & & & $\begin{array}{l}-10.941 \\
{[t=-4.030} \\
p=.000]\end{array}$ \\
\hline $\begin{array}{l}\text { No. Of Obs. } \\
\text { F-Value } \\
\text { Adjusted } R^{2}\end{array}$ & $\begin{array}{l}1464 \\
2430.698 \\
.833\end{array}$ & $\begin{array}{l}1464 \\
2428.017 \\
.833\end{array}$ & $\begin{array}{l}1464 \\
1487.275 \\
.836\end{array}$ & $\begin{array}{l}1464 \\
1256.053 \\
.837\end{array}$ & $\begin{array}{l}1464 \\
2144.377 \\
.815\end{array}$ & $\begin{array}{l}1464 \\
3181.720 \\
.813\end{array}$ & $\begin{array}{l}1464 \\
1088.080 \\
.817\end{array}$ \\
\hline
\end{tabular}

The signs on the coefficients on the cumulative foreign currency translations (FOREX/S in models 3c and 3d), as well as that on the pension adjustment (PENADJ/S in model 3d) turn out to be negative, and significant at $\mathrm{p}<.01$ level. The former result is consistent with Louis (2003), who argues that foreign currency translation adjustments are negatively associated with firm valuation. The latter result appears qualitatively consistent with the findings of Barth, Beaver and 
Landsman (1992). A higher pension adjustment in the current period indicates a higher pension expense in future periods, which would result in a decrease in future earnings. This fact is priced by the market.

Ohlson (1999) models stock price as a function of book value, abnormal earnings and transitory earnings (OCI). He predicts that OCI would not be value relevant, and that the coefficient on OCI should be statistically insignificant. Further, Ohlson (1999) predicts that the sum of the coefficients on abnormal earnings and OCI would be statistically equal to zero. This is because abnormal earnings and transitory earnings (OCI) are expected to have zero means (page 148). These predictions are tested as models 3e and 3f.

As reported in table 6.5, the coefficients on book value and abnormal earnings are positive and significant at a $\mathrm{p}<.01$ level. The coefficient on $\mathrm{OCI}_{1530}$ is negative and insignificant. This result is very different from the result of model 3a, under which the coefficient on $\mathrm{OCI}_{1530}$ was found to be positive and significant at a $\mathrm{p}<.01$ level. The outcome under model 3e is as Ohlson (1999) predicts in terms of significance. The negative sign indicates that aggregate OCI is valuereducing. To explore this result further, I replace $\mathrm{OCI}_{1530}$ with its individual components, namely, HEDGE, SEC and FOREX, and include the additional component under $\mathrm{OCI}_{130}$ (PENADJ) and re-run model 3e as model 3g. None of the individual components of OCI1530 turns up as significant. However, PENADJ (which is an additional component of OCI under SFAS 130) proves to be significantly, though negatively, associated with stock price, suggesting that when firms do report information on it, the markets price it in.

The findings for models 3e through 3g do not appear to support value relevance. In fact, they support Ohlson's (1999) prediction that OCI is value irrelevant beyond what is explained by abnormal earnings. To test whether the sum of the coefficients on abnormal earnings and $\mathrm{OCI}_{1530}$ statistically equals zero, I compute an incremental F-statistic as $F_{J, N-K-1}=\frac{\left(R_{U}^{2}-R_{C}^{2}\right) *(N-K-J)}{\left(1-R_{U}^{2}\right) * J}$, where the number of constraints, $\mathrm{J}=1, \mathrm{~N}=1464, \mathrm{~K}=3, R_{U}^{2}=$ 
.815 and $R_{C}^{2}=.813$. Accordingly, the F-statistic equals $15.783^{29}$, implying a t-statistic of 3.97, which is significant at a $\mathrm{p}<.01$ level. Thus, we reject the hypothesis that the sum of coefficients on abnormal earnings and $\mathrm{OCI}_{1530}$ is equal to zero. However, this result is moot since I did not find any significance for either aggregate $\mathrm{OCI}_{1530}$ or its components.

\subsubsection{Returns (Change) Regressions to test value-relevance of OCI and components}

The valuation (level) regressions described in the previous section reported significant association between OCI and components with share price. In this section, I report the results for the following returns (change) regressions:

$$
\begin{aligned}
& R E T_{i t}=\phi_{0}+\phi_{1} N I_{i t}+\phi_{2} O C I_{1530 i t}+\varepsilon_{i t} \\
& R E T_{i t}=\phi_{0}+\phi_{1} N I_{i t}+\phi_{2} O C I_{130 i t}+\varepsilon_{i t} \\
& R E T_{i t}=\phi_{0}+\phi_{1} N I_{i t}+\phi_{2} H E D G E_{i t}+\phi_{3} S E C_{i t}+\phi_{4} F O R E X_{i t}+\varepsilon_{i t} \\
& R E T_{i t}=\phi_{0}+\phi_{1} N I_{i t}+\phi_{2} H E D G E_{i t}+\phi_{3} S E C_{i t}+\phi_{4} F O R E X_{i t}+\phi_{5} P E N A D J_{t}+\varepsilon_{i t} \quad \text { [4d] } \\
& R E T_{i t}=\phi_{0}+\phi_{1} N I_{i t}+\phi_{2} H E D G E_{i t}+\phi_{3} S E C_{i t}+\phi_{4} F O R E X_{i t}+\phi_{5} P_{E N A D J_{t}}+\phi_{6} D_{1} * N I_{i t}+\phi_{7} \\
& D_{2} * N I_{i t}+\varepsilon_{i t}
\end{aligned}
$$

where all variables other than RET are scaled by the market value of common equity at the beginning of the fiscal year

As reported in Table 6.6, the coefficients on net income and OCI - both aggregate as well as components - are all significant at conventional levels. All coefficients are positive. The results indicate that net income, aggregate OCI, HEDGE and SEC are more strongly associated with stock returns (all at a $\mathrm{p}<0.01$ level) than are FOREX and PENADJ (both at a $\mathrm{p}<0.10$ level). The adjusted r-squared is higher for models 4c and 4d, which include components of OCI than for models 4a and 4b, which include aggregate OCI. Kanagaretnam et al (2009) had found only the coefficients for HEDGE and SEC to be significantly associated with stock returns, whereas I find

$$
\begin{aligned}
& { }^{29} F_{J, N-K-1}=\frac{\left(R_{U}^{2}-R_{C}^{2}\right) *(N-K-J)}{\left(1-R_{U}^{2}\right) * J}=\frac{(.815-.813) *(1464-3-1)}{(1-.815) * 1}=15.783 \\
& \text { t-statistic }=\sqrt{15.783}=3.972
\end{aligned}
$$


the coefficients for FOREX (models 4c and 4d) and PENADJ (model 4d) to be marginally significantly associated with stock returns at a $\mathrm{p}<.1$ level. However, the significance of the association is lost under model 4e, where I include the dummy variables for negative net income $\left(D_{1}\right)$ and post 2006 years $\left(D_{2}\right)$. The significance for HEDGE and SEC is not materially altered. These results indicate that stock returns were significantly different for loss making firms $(\mathrm{p}<.1)$ as predicted by Hayn (1995), as well as for the post 2006 period ( $p<.05$ ). I discuss the significance of the study period later in the concluding chapter.

My results differ from those of Kanagaretnam et al (2009) in two major respects. First, the sign on the coefficient for HEDGE is positive, whereas Kanagaretnam et al report the coefficient to be negative. Theoretically, a positive coefficient is more plausible, as it would suggest that a gaining position for a cash flow hedge would indicate better performance and thus be associated with higher stock returns. In fact, when Kanagaretnam et al parse their data on HEDGE into winning and losing positions, they do find the coefficient for winning hedge positions to be positive. 
Table 6-6: Returns (Change) Regressions to test value-relevance of OCI and components

\begin{tabular}{|c|c|c|c|c|c|}
\hline Dependent Variable & \multicolumn{5}{|c|}{ Ret $_{i t}$} \\
\hline Independent Variables & Model 4a & Model 4b & Model 4c & Model 4d & Model 4e \\
\hline Intercept & $\begin{array}{l}.080 \\
{[t=5.140} \\
p=.000]\end{array}$ & $\begin{array}{l}.080 \\
{[t=5.148} \\
p=.000]\end{array}$ & $\begin{array}{l}.074 \\
{[t=4.815} \\
p=.000]\end{array}$ & $\begin{array}{l}.075 \\
{[t=4.861} \\
p=.000]\end{array}$ & $\begin{array}{l}.053 \\
{[t=2.895} \\
p=.004]\end{array}$ \\
\hline$N I_{i t}$ & $\begin{array}{l}.248 \\
{[t=5.578} \\
p=.000]\end{array}$ & $\begin{array}{l}.252 \\
{[t=5.664} \\
p=.000]\end{array}$ & $\begin{array}{l}.255 \\
{[t=5.697} \\
p=.000]\end{array}$ & $\begin{array}{l}.278 \\
{[t=5.971} \\
p=.000]\end{array}$ & $\begin{array}{l}1.599 \\
{[t=3.194} \\
p=.001]\end{array}$ \\
\hline $\mathrm{OCI}_{1530 \mathrm{it}}$ & $\begin{array}{l}.550 \\
{[t=5.769} \\
p=.000]\end{array}$ & & & & \\
\hline$\overline{O C I_{130 i t}}$ & & $\begin{array}{l}.557 \\
{[t=5.851} \\
p=.000]\end{array}$ & & & \\
\hline$\overline{H E D G E_{i t}}$ & & & $\begin{array}{l}.612 \\
{[t=4.460} \\
p=.000]\end{array}$ & $\begin{array}{l}.634 \\
{[t=4.607} \\
p=.000]\end{array}$ & $\begin{array}{l}.598 \\
{[t=4.327} \\
p=.000]\end{array}$ \\
\hline$\overline{S E C_{i t}}$ & & & $\begin{array}{l}2.986 \\
{[t=7.009} \\
p=.000]\end{array}$ & $\begin{array}{l}2.977 \\
{[t=6.995} \\
p=.000]\end{array}$ & $\begin{array}{l}2.893 \\
{[t=6.778} \\
p=.000]\end{array}$ \\
\hline FOREX $_{i t}$ & & & $\begin{array}{l}.253 \\
{[t=1.864} \\
p=.063]\end{array}$ & $\begin{array}{l}.243 \\
{[t=1.787} \\
p=.074]\end{array}$ & $\begin{array}{l}.163 \\
{[t=1.153} \\
p=.249]\end{array}$ \\
\hline$\overline{P E N A D J}_{i t}$ & & & & $\begin{array}{l}3.162 \\
{[t=1.776} \\
p=.076]\end{array}$ & $\begin{array}{l}2.605 \\
{[\mathrm{t}=1.453} \\
\mathrm{p}=.146]\end{array}$ \\
\hline$D_{1} * N I_{i t}$ & & & & & $\begin{array}{l}-.283 \\
{[t=-1.963} \\
p=.050]\end{array}$ \\
\hline$D_{2} * N I_{i t}$ & & & & & $\begin{array}{l}-1.097 \\
{[\mathrm{t}=-2.215} \\
\mathrm{p}=.027]\end{array}$ \\
\hline $\begin{array}{l}\text { No. of observations } \\
\text { F-Value } \\
\text { Adjusted } R^{2}\end{array}$ & $\begin{array}{l}1097 \\
31.002 \\
.052 \\
\end{array}$ & $\begin{array}{l}1097 \\
31.494 \\
.053 \\
\end{array}$ & $\begin{array}{l}1097 \\
25.532 \\
.082 \\
\end{array}$ & $\begin{array}{l}1097 \\
21.097 \\
.088 \\
\end{array}$ & $\begin{array}{l}1097 \\
16.498 \\
.090 \\
\end{array}$ \\
\hline
\end{tabular}

\section{2 .5}


6.2.6 Regressions to test association of OCI and components with analyst forecasts

To test the association of OCI and components with analyst forecasts of earnings per share, I estimate the following equations:

$$
\begin{aligned}
& \text { IBESMean }_{i t}=\varphi_{0}+\varphi_{1} \text { EPS }_{i t-1}+\varphi_{2} \operatorname{LnMVE}_{i t-1}+\varphi_{3} \operatorname{LnTV}_{i t}+\varphi_{4} \mathrm{LnFol}_{i t}+\varphi_{5} \mathrm{OCI}_{1530 i t-1} \\
& +\varphi_{6} \mathrm{OCI}_{1530 i t}+\varepsilon_{i t} \\
& \text { IBESMean }_{i t}=\varphi_{0}+\varphi_{1} \text { EPS }_{i t-1}+\varphi_{2} \text { LnMVE }_{i t-1}+\varphi_{3} \operatorname{LnTV}_{i t}+\varphi_{4} \text { LnFol }_{i t}+\varphi_{5}{\text { HEDGE } / S_{i t}}+\varphi_{6}{\text { SEC } / S_{i t}}_{i t}
\end{aligned}
$$

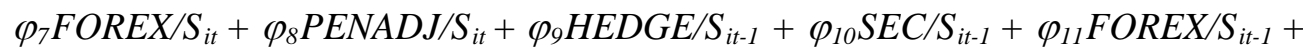

$$
\begin{aligned}
& \varphi_{12} P E N A D J / S_{i t-1}+\varepsilon_{i t} \\
& \text { IBESMed }_{i t}=\varphi_{0}+\varphi_{1} \text { EPS }_{i t-1}+\varphi_{2} \operatorname{LnMVE}_{i t-1}+\varphi_{3} \operatorname{LnTV}_{i t}+\varphi_{4} \text { LnFol }_{i t}+\varphi_{5} \mathrm{OCI}_{1530 i t-1} \\
& +\varphi_{6} \mathrm{OCI}_{1530 i t}+\varepsilon_{i t}
\end{aligned}
$$

where the variables are as defined in earlier sections

The results of the association tests are reported in Table 6.7. The results are qualitatively similar for both models. The adjusted r-squareds are between 42 per cent and 46 per cent. Lagged EPS and OCI per share, as well as current year's OCI per share are positively associated with analysts’ mean (model 5a) and median (model 6a) earnings per share forecasts at the $\mathrm{p}<.01$ level.

In the expanded models (models $5 \mathrm{~b}$ and $6 \mathrm{~b}$ ) where I replace aggregate $\mathrm{OCI}_{1530}$ with its components, I find that except for the current year available for sale securities (SEC), each of the other components, as well as the lagged values, is positively associated with analysts' earnings forecasts at better than a $\mathrm{p}<.05$ level. The additional component under $\mathrm{OCI}_{130}$, the minimum pension adjustment (PENADJ), is also significantly, but negatively, associated with analysts' earnings forecasts. 
Among the control variables, market capitalization (natural logarithm of beginning Market Value of Equity) is positively associated with analysts' earnings forecasts, confirming the findings of $\mathrm{Gu}$ and $\mathrm{Wu}$ (2003). As well, trading volume is significantly negatively associated with analysts' forecasts. This could be interpreted to mean that analysts' earnings forecasts tend to be optimistic (conservative) for thinly (heavily) traded stocks. The number of analysts following a stock, another variable reported in the literature to be significantly associated with analysts’ earnings forecasts, proved to be insignificant.

A possible concern for these models testing the association of OCI and components with analysts' forecasts could be that it might suffer from multicollinearity. Multicollinearity arises when a substantial portion of the variance in a variable is explained by other independent variables. It is identified by measuring the tolerance for the selected independent variable. The tolerance value should be high to indicate low multicollinearity. It is common practice to convert the tolerance metric into a variance inflation factor (VIF) value, which is equal to the inverse of the tolerance. A common cut-off threshold for multicollinearity is a VIF value of 10, corresponding to a tolerance of 0.10 (Hair et al. 2010). However, this is not a problem for the model, as none of the variables in the model has variance inflation factor (VIF) values of greater than 2.5. That is, the tolerance for none of the variables is less than 0.40 . The only variables with a VIF value greater than 2 were FOREX and its lagged value. 
Table 6-7 Regressions to test association of OCI and components with analysts' forecasts

\begin{tabular}{|c|c|c|c|c|}
\hline Dependent Variable & \multicolumn{2}{|c|}{ IBESMean $_{i t}$} & \multicolumn{2}{|c|}{ IBESMed $_{i t}$} \\
\hline Independent Variables & Model 5a & Model 5b & Model 6a & Model 6b \\
\hline Intercept & $\begin{array}{l}-1.013 \\
{[t=-2.191} \\
p=.029]\end{array}$ & $\begin{array}{l}-.786 \\
{[t=-1.725} \\
p=.085]\end{array}$ & $\begin{array}{l}-1.013 \\
{[t=-2.151} \\
p=.032]\end{array}$ & $\begin{array}{l}-.767 \\
{[t=-1.657} \\
p=.098]\end{array}$ \\
\hline$E P S_{i t-1}$ & $\begin{array}{l}.226 \\
{[t=9.620} \\
p=.000]\end{array}$ & $\begin{array}{l}.221 \\
{[t=9.616} \\
p=.000]\end{array}$ & $\begin{array}{l}.227 \\
{[t=9.482} \\
p=.000]\end{array}$ & $\begin{array}{l}.222 \\
{[t=9.496} \\
p=.000]\end{array}$ \\
\hline$O C I / S_{1530 i t-1}$ & $\begin{array}{l}.432 \\
{[t=6.206} \\
p=.000]\end{array}$ & & $\begin{array}{l}.434 \\
{[t=6.119} \\
p=.000]\end{array}$ & \\
\hline$\overline{O C I} / S_{1530 i t}$ & $\begin{array}{l}.370 \\
{[t=6.924} \\
p=.000]\end{array}$ & & $\begin{array}{l}.366 \\
{[t=6.731} \\
p=.000]\end{array}$ & \\
\hline $\operatorname{LnMVE}_{i t-1}$ & $\begin{array}{l}.609 \\
{[t=13.333} \\
p=.000]\end{array}$ & $\begin{array}{l}.593 \\
{[t=13.153} \\
p=.000]\end{array}$ & $\begin{array}{l}.609 \\
{[t=13.101} \\
p=.000]\end{array}$ & $\begin{array}{l}.592 \\
{[t=12.932} \\
p=.000]\end{array}$ \\
\hline $\operatorname{LnTV}_{\text {it }}$ & $\begin{array}{l}-.172 \\
{[\mathrm{t}=-5.237} \\
\mathrm{p}=.000]\end{array}$ & $\begin{array}{l}-.181 \\
{[t=-5.603} \\
p=.000]\end{array}$ & $\begin{array}{l}-.173 \\
{[\mathrm{t}=-5.158} \\
\mathrm{p}=.000]\end{array}$ & $\begin{array}{l}-.182 \\
{[t=-5.556} \\
p=.000]\end{array}$ \\
\hline $\operatorname{LnFol}_{i t}$ & $\begin{array}{l}.082 \\
{[t=1.214} \\
p=.225]\end{array}$ & $\begin{array}{l}.088 \\
{[t=1.343} \\
p=.180]\end{array}$ & $\begin{array}{l}.086 \\
{[t=1.252} \\
p=.211]\end{array}$ & $\begin{array}{l}.093 \\
{[t=1.397} \\
p=.163]\end{array}$ \\
\hline$H E D G E / S_{i t}$ & & $\begin{array}{l}.471 \\
{[t=6.702} \\
p=.000]\end{array}$ & & $\begin{array}{l}.470 \\
{[t=6.588} \\
p=.000]\end{array}$ \\
\hline$\overline{S E C / S_{i t}}$ & & $\begin{array}{l}.068 \\
{[t=.469} \\
p=.639]\end{array}$ & & $\begin{array}{l}.052 \\
{[t=.352} \\
p=.725]\end{array}$ \\
\hline$F O R E X / S_{i t}$ & & $\begin{array}{l}.320 \\
{[t=3.662} \\
p=.000]\end{array}$ & & $\begin{array}{l}.315 \\
{[t=3.547} \\
p=.000]\end{array}$ \\
\hline PENADJ/S ${ }_{i t}$ & & $\begin{array}{l}-1.149 \\
{[t=-1.763} \\
p=.078]\end{array}$ & & $\begin{array}{l}-1.158 \\
{[t=-1.750} \\
p=.081]\end{array}$ \\
\hline HEDGE/S $S_{i t-1}$ & & $\begin{array}{l}.422 \\
{[t=5.235} \\
p=.000]\end{array}$ & & $\begin{array}{l}.421 \\
{[t=5.151} \\
p=.000]\end{array}$ \\
\hline$S E C / S_{i t-1}$ & & $\begin{array}{l}1.566 \\
{[t=5.899} \\
p=.000]\end{array}$ & & $\begin{array}{l}1.653 \\
{[t=6.135} \\
p=.000]\end{array}$ \\
\hline FOREX/S $S_{i t-1}$ & & $\begin{array}{l}.307 \\
{[t=2.112} \\
p=.035]\end{array}$ & & $\begin{array}{l}.299 \\
{[t=2.025} \\
p=.043]\end{array}$ \\
\hline$P E N A D J / S_{i t-1}$ & & $\begin{array}{l}-1.718 \\
{[t=-1.854} \\
p=.064]\end{array}$ & & $\begin{array}{l}-1.706 \\
{[t=-1.813} \\
p=.070]\end{array}$ \\
\hline $\begin{array}{l}\text { No. of observations } \\
\text { F-Value } \\
\text { Adjusted } R^{2}\end{array}$ & $\begin{array}{l}675 \\
84.926 \\
.428\end{array}$ & $\begin{array}{l}675 \\
49.052 \\
.461\end{array}$ & $\begin{array}{l}675 \\
82.341 \\
.420\end{array}$ & $\begin{array}{l}675 \\
48.277 \\
.457\end{array}$ \\
\hline
\end{tabular}


How should I interpret the above results? From a purely accounting point of view, it may be argued that since the earnings-per-share calculation does not include OCI, there should be no reason to expect any association between analysts' EPS forecasts and OCI. The counterargument could be that by the time the firms announce their earnings, some of the unrealized earnings items previously included in OCI could have been realized, and thus, included in their forecasts by the analysts. For example, unrealized gains and losses on available for sale securities reported in OCI in the previous year, may have been realized in the current year. This would explain my finding of a significant association between lagged available for sale securities $\left(S E C / S_{i t-1}\right)$ and analysts' earnings forecasts. Furthermore, as analysts also have access to sources of information other than accounting data, they might anticipate (if not know) the status of firms' cash flow hedges, and thus include this information in their earnings forecast calculations.

\subsubsection{Regressions to test association of OCI and components with analyst forecast error}

To test for the potential association of OCI and its components with analyst forecast error, I test the following regressions. Following the literature, I control for several variables, including the dispersion between the mean and median consensus forecasts, accruals, firm size, trading volume, analyst following and for loss making firms.

$$
\begin{aligned}
\text { FERR }_{i t}= & \lambda_{0}+\lambda_{1} \text { MNMD }_{i t}+\lambda_{2} \text { OCI }_{1530 i t}+\lambda_{3} \text { Accruals }_{\text {S }}+\lambda_{4} \text { LnMVE }_{i t-1}+\lambda_{5} \text { LnTV }_{i t}+ \\
& \lambda_{6} \text { LnFol }_{i t}+\lambda_{7} \text { NegNI }+\varepsilon_{i t} \\
\text { FERR }_{i t}= & \lambda_{0}+\lambda_{1} \text { MNMD }_{i t}+\lambda_{2} \text { Accruals }+\lambda_{3}{\text { HEDGE } / S_{i t}+\lambda_{4} S E C / S_{i t}+\lambda_{5} F O R E X / S_{i t}+}+ \\
& \lambda_{6} \text { LnMVE }_{i t-1}+\lambda_{7} \text { LnTV }_{i t}+\lambda_{8} \text { LnFol }_{i t}+\lambda_{9} N e g N I+\varepsilon_{i t}
\end{aligned}
$$

where,

$F E R R_{i t}$ is the forecast error in mean consensus analysts' earnings forecast, calculated as (Actual EPS IBESMean)/Price ${ }_{\text {it-1 }}$

$M N M D_{i t}$ is the difference between the mean and median consensus analyst earnings forecasts, calculated as (IBESMean - IBESMed)/ Price $_{\text {it-1 }}$

Accruals $/ S_{i t}$ is the per share amount of accruals, calculated as the difference between Operating Cash Flow per share and Net Income per share. 
Other variables are as defined in earlier sections

The results of the association tests are reported in Table 6.8. Aggregate OCI is negatively associated with analyst forecast error at a $\mathrm{p}<.05$ level. This suggests that the availability of information of other comprehensive income could be helpful to analysts in making more accurate earnings forecasts. However, individual components of OCI do not appear to be as strongly associated with analysts’ forecast errors. Only unrealized gains and losses on cash flow hedges $\left(H E D G E / S_{i t}\right)$ was found to be negatively and significantly $(\mathrm{p}<.01)$ associated with analysts' forecast errors. Interestingly, the additional component under $\mathrm{OCI}_{130}$, namely the minimum pension adjustment $\left(P E N A D J / S_{i t}\right)$ is positively and significantly $(\mathrm{p}<.01)$ associated with analysts' forecast errors. This implies that including information contained in PENADJ could actually increase the magnitude of analysts’ forecast errors.

Among the control variables, the difference between the mean and median forecasts ( $M N M D$ ) proved to be the largest contributor to forecast errors, with a positive association at the $\mathrm{p}<.01$ level. Interestingly, accruals are negatively associated with forecast error $(\mathrm{p}<.01)$, suggesting that analysts are able to correctly control for the effect of accruals in their earnings forecasts. This result appears to be puzzling initially, since it goes against the well-known accruals anomaly cited by Sloan (1996). A possible explanation could be that over the years, analysts might have begun paying closer attention to the information conveyed by accruals, and have become better able to use such information in improving their earnings forecast accuracy.

Trading volume (LnTV), market capitalization (LnMVE) and the number of analysts following a stock ( $\mathrm{LnFol}$ ) did not prove to be significantly associated with analysts' forecast errors. However, the incidence of losses (NegNI) does appear to contribute to greater forecast accuracy, as it is negatively and significantly associated $(\mathrm{p}<.01)$ with analysts forecast error. 
Table 6-8 Regressions to test association of OCI and components with analyst forecast error

\begin{tabular}{|c|c|c|}
\hline Dependent Variable & \multicolumn{2}{|c|}{$F E R R_{i t}$} \\
\hline Independent Variables & Model 7a & Model 7b \\
\hline Intercept & $\begin{array}{l}.095 \\
{[t=1.588} \\
p=.113]\end{array}$ & $\begin{array}{l}.066 \\
{[t=1.142} \\
p=.254]\end{array}$ \\
\hline$\overline{M N M D_{i t}}$ & $\begin{array}{l}4.064 \\
{[t=5.186} \\
p=.000]\end{array}$ & $\begin{array}{l}4.006 \\
{[t=5.288} \\
p=.000]\end{array}$ \\
\hline Accruals/S $S_{i t}$ & $\begin{array}{l}.012 \\
{[t=-5.955} \\
p=.000]\end{array}$ & $\begin{array}{l}-.012 \\
{[t=-6.035} \\
p=.000]\end{array}$ \\
\hline $\operatorname{LnMVE}_{i t}$ & $\begin{array}{l}-.005 \\
{[t=-.813} \\
p=.416]\end{array}$ & $\begin{array}{l}-.008 \\
{[t=-1.294} \\
p=.196]\end{array}$ \\
\hline$\overline{L n T V_{i t}}$ & $\begin{array}{l}-.002 \\
{[t=-.525} \\
p=.600]\end{array}$ & $\begin{array}{l}.001 \\
{[t=.238} \\
p=.812]\end{array}$ \\
\hline LnFol $_{i t}$ & $\begin{array}{l}.003 \\
{[t=.352} \\
p=.725]\end{array}$ & $\begin{array}{l}.002 \\
{[\mathrm{t}=.239} \\
\mathrm{p}=.812]\end{array}$ \\
\hline NegNI & $\begin{array}{l}.125 \\
{[t=-7.397} \\
p=.000]\end{array}$ & $\begin{array}{l}.132 \\
{[t=-8.056} \\
p=.000]\end{array}$ \\
\hline$O C I / S_{1530 i t}$ & $\begin{array}{l}-.023 \\
{[t=-4.046} \\
p=.000]\end{array}$ & \\
\hline$\overline{H E D G E / S_{i t}}$ & & $\begin{array}{l}-.054 \\
{[\mathrm{t}=-7.010} \\
\mathrm{p}=.000]\end{array}$ \\
\hline$\overline{S E C / S_{i t}}$ & & $\begin{array}{l}.011 \\
{[t=-.632} \\
p=.528]\end{array}$ \\
\hline$\overline{F O R E X / S_{i t}}$ & & $\begin{array}{l}.007 \\
{[t=.915} \\
p=.360]\end{array}$ \\
\hline$P E N A D J / S_{i t}$ & & $\begin{array}{l}.318 \\
{[t=4.650} \\
p=.000]\end{array}$ \\
\hline $\begin{array}{l}\text { No. of observations } \\
\text { F-Value } \\
\text { Adjusted } R^{2}\end{array}$ & $\begin{array}{l}675 \\
23.723 \\
.191\end{array}$ & $\begin{array}{l}675 \\
22.788 \\
.244\end{array}$ \\
\hline
\end{tabular}




\subsection{Robustness tests}

To ensure the robustness of my analyses, I conducted additional tests which are described in the following sub-sections. I first control for potential effects of size, leverage and industryspecific factors. Next, to test whether my use of an expected rate of 12 per cent in estimating abnormal earnings produced robust results, I use alternative specifications of expected return on assets and re-run the regressions testing forecasting ability and predictability of OCI and components. Finally, to test for alternative indicators of decision usefulness, I test for the ability of OCI to predict future net income and operating cash flows.

\subsubsection{Controlling for size, leverage and industry}

It is possible that much of the variation in dependent variables that my regression models seek to capture could be explained by firm size, leverage or industry-specific factors. The justification for including these control variables was discussed in To ensure the robustness of my results to potential, I re-ran the regressions including control variables for size (natural logarithm of total assets per share, $\operatorname{LnTA} / S$ ), leverage (Debt-Equity ratio) and industry (dummy variables for Mining, Manufacturing and Financial, at the 2-digit SIC code level). The following sections report the results of these tests.

\subsubsection{Regressions testing the ability of OCI and its components to forecast future abnormal earnings}

As reported in table 6.9 below, except for size, none of the control variables are significant, while the original results (reported in table 6.3) remain materially unaltered. Aggregate $\mathrm{OCI}_{1530}$ is significantly positively associated with future abnormal earnings, as are HEDGE and SEC at a $\mathrm{p}<.01$ level. FOREX is not significantly associated with future abnormal earnings. Size, proxied by the natural logarithm of total assets per share, is negatively associated with future abnormal earnings at a $\mathrm{p}<.05$ level. This indicates that larger firms experience less abnormal earnings, that is, their earnings tend to be more stable. The additional component under $\mathrm{OCI}_{130}, \mathrm{PENADJ}$, is negatively associated with future abnormal earnings at a $\mathrm{p}<.01$ level, indicating that the incidence of a pension adjustment is able to forecast lower abnormal earnings in the future. This could possibly be because of greater pension expense recognition in the following year. 
Table 6-9: Regression to test the ability of OCI and its components to forecast future abnormal earnings

\begin{tabular}{|c|c|c|c|c|c|c|}
\hline \multirow{3}{*}{$\begin{array}{l}\text { Dependent } \\
\text { Variable }\end{array}$} & \multicolumn{6}{|c|}{ AbnEarn $_{\text {it }}$} \\
\hline & \multicolumn{3}{|c|}{ Aggregate $\mathrm{OCI}_{1530}$} & \multicolumn{3}{|c|}{ OCI $_{1530}$ components } \\
\hline & Coefficient & t-statistic & p-value & Coefficient & t-statistic & $\mathrm{p}$-value \\
\hline Intercept & -.064 & -.370 & .711 & -.039 & -.234 & .815 \\
\hline AbnEarn $_{i t-1}$ & .261 & 11.108 & .000 & .239 & 9.877 & .000 \\
\hline $\mathrm{OCI}_{1530 i t-1}$ & .379 & 8.234 & .000 & & & \\
\hline$H E D G E_{i t-1}$ & & & & .779 & 10.183 & .000 \\
\hline$S E C_{i t-1}$ & & & & .345 & 3.565 & .000 \\
\hline FOREX $X_{i t-1}$ & & & & .074 & 1.029 & .304 \\
\hline${ }_{P E N A D J_{i t-1}}$ & & & & -2.598 & -3.846 & .000 \\
\hline $\operatorname{LnTA} / S_{i t}$ & -.091 & -2.119 & .034 & -.106 & -2.538 & .011 \\
\hline Debt_Equity & .002 & .533 & .594 & .002 & .529 & .597 \\
\hline Mining & -.086 & -.540 & .589 & -.090 & -.578 & .564 \\
\hline Manufacturing & -.145 & -.857 & .392 & $\begin{array}{l}.090 \\
\end{array}$ & $\begin{array}{l}-893 \\
\end{array}$ & .372 \\
\hline Financial & -.085 & -.445 & .656 & -.108 & -.576 & .564 \\
\hline $\begin{array}{l}\text { No. of } \\
\text { observations }\end{array}$ & 1074 & & & 1074 & & \\
\hline F-Value & 21.846 & & & 22.321 & & \\
\hline Adjusted $R^{2}$ & .120 & & & .166 & & \\
\hline
\end{tabular}

\subsubsection{Regression to test predictability of OCI}

As reported in table 6.10 below, none of the control variables are significant, while the original results (reported in table 6.4) remain materially unaltered, except for a slight diminution in significance for lagged abnormal earnings and HEDGE. Aggregate lagged $\mathrm{OCI}_{1530}$ is significantly associated with current $\mathrm{OCI}_{1530}$ at a $\mathrm{p}<.01$ level, as are lagged HEDGE, SEC and FOREX. PENADJ is not found to be able to predict future $\mathrm{OCI}_{1530}$. This makes sense, since the PENADJ is not a component of $\mathrm{OCI}_{1530}$. These results are robust to differences in size, leverage or industry differences. 
Table 6-10: Regressions to test predictability of OCI and components

\begin{tabular}{|c|c|c|c|c|c|c|}
\hline \multirow[t]{3}{*}{ Dependent Variable } & \multicolumn{6}{|c|}{ OCI $_{1530 i t}$} \\
\hline & \multicolumn{3}{|c|}{ Aggregate $\mathrm{OCI}_{1530}$} & \multicolumn{3}{|c|}{ OCI $_{1530}$ components } \\
\hline & Coefficient & t-statistic & p-value & Coefficient & t-statistic & p-value \\
\hline Intercept & -.102 & -.914 & .361 & -.102 & -1.037 & .300 \\
\hline AbnEarn $_{\text {it-1 }}$ & .099 & 6.479 & .000 & .019 & 1.331 & .183 \\
\hline$O_{1530 i t-1}$ & -.882 & -29.645 & .000 & & & \\
\hline$H E D G E_{i t-1}$ & & & & -.443 & -9.898 & .000 \\
\hline$S E C_{i t-1}$ & & & & -1.705 & -30.128 & .000 \\
\hline FOREX $X_{i t-1}$ & & & & -.735 & -17.434 & .000 \\
\hline${ }_{P E N A D J_{i t-1}}$ & & & & .104 & .262 & 793 \\
\hline $\operatorname{LnTA}_{\mathbf{S}} \mathrm{S}_{\text {it }}$ & .030 & 1.086 & .278 & .023 & .931 & .352 \\
\hline Debt_Equity & -.001 & -.351 & .725 & .000 & -.202 & .840 \\
\hline Mining & .057 & .553 & .580 & .060 & .655 & .513 \\
\hline Manufacturing & .036 & .331 & .740 & .023 & .243 & .808 \\
\hline Financial & .086 & .697 & .486 & $\begin{array}{l}.044 \\
\end{array}$ & $\begin{array}{l}-398 \\
\end{array}$ & .690 \\
\hline No. of observations & 1074 & & & 1074 & & \\
\hline F-Value & 172.485 & & & 186.102 & & \\
\hline Adjusted $R^{2}$ & .528 & & & .633 & & \\
\hline
\end{tabular}

\subsubsection{Valuation (Level) Regressions to test value-relevance of OCI and components}

The results of the basic valuation regressions to test value relevance of OCI and its components were reported in Table 6.5. Both aggregate OCI and its components were found to be associated with stock price at conventional levels of statistical significance. In addition to controls for size, debt-equity and industry, I included additional controls to test whether (i) the timing of adoption of HB1530 caused significance variation in the amounts of OCI reported, (ii) macroeconomic factors such as the exchange rate, the rate of gross domestic product (GDP) and interest rates had any significant influence on the results. The results of these additional tests are reported in table 6.11 . 
The addition of control variables does not have a material impact on the results. Aggregate $\mathrm{OCI}_{1530}$ (the result is similar for $\mathrm{OCI}_{130}$ ) is still positively associated with stock price at a $\mathrm{p}<.01$ level. As for the individual components of $\mathrm{OCI}_{1530}$, except for HEDGE (which was found to be only marginally associated with stock price in the original regressions), they are all still significantly associated with stock price at a $\mathrm{p}<.05$ or better level.

Table 6-11: Valuation regression to test value relevance of OCI and components

\begin{tabular}{|c|c|c|c|c|c|c|}
\hline Dependent Variable & \multicolumn{3}{|c|}{$P / S_{i t}$} & \multicolumn{3}{|c|}{$P / S_{i t}$} \\
\hline & Coefficient & t-statistic & p-value & Coefficient & t-statistic & p-value \\
\hline Intercept & -10.677 & $\begin{array}{l}-.986 \\
\end{array}$ & .324 & -11.734 & -1.092 & .275 \\
\hline$B V E / S_{i t}$ & .633 & 52.984 & .000 & .627 & 51.911 & .000 \\
\hline$N I / S_{i t}$ & 1.430 & 15.815 & .000 & 1.549 & 16.137 & .000 \\
\hline OCI $/ S_{1530 i t}$ & .496 & 5.036 & .000 & & & \\
\hline$H E D G E / S_{i t}$ & & & & .585 & 1.479 & .139 \\
\hline$\overline{S E C / S_{i t}}$ & & & & .661 & 5.995 & .000 \\
\hline FOREX/S ${ }_{i t}$ & & & & -.704 & -2.008 & .045 \\
\hline$\overline{P E N A D J / S_{i t}}$ & & & & -10.001 & -4.330 & .000 \\
\hline $\operatorname{LnTA} / S_{i t}$ & 2.288 & 11.111 & .000 & 2.224 & 10.888 & .000 \\
\hline Debt_Equity & .020 & .896 & .370 & .020 & .893 & .372 \\
\hline Mining & -.159 & -.224 & .823 & -.010 & -.015 & .988 \\
\hline Manufacturing & -3.158 & -4.209 & .000 & -3.030 & -4.077 & .000 \\
\hline Financial & -2.303 & -2.731 & .006 & -2.135 & -2.554 & .011 \\
\hline Adoption & -12.930 & -8.795 & .000 & -12.900 & -8.821 & .000 \\
\hline ExchRate $_{t}$ & 15.538 & 1.344 & .179 & 16.425 & 1.432 & .152 \\
\hline$G D P_{t}$ & 17.705 & .789 & .430 & 14.740 & .662 & .508 \\
\hline IntRate $_{t}$ & 295.927 & 6.143 & .000 & 303.854 & 6.343 & .000 \\
\hline No. of observations & 1,464 & & & 1,464 & & \\
\hline F-Value & 791.524 & & & 648.085 & & \\
\hline Adjusted $R^{2}$ & .866 & & & .869 & & \\
\hline
\end{tabular}


Among the control variables, size is found to be highly significantly associated with stock price, whereas leverage (debt-equity) seems to have no association with stock price at all. The results also point to significant industry level differences with significantly negative association found for the manufacturing and the financial sectors $(\mathrm{p}<.05)$. Further, the timing of adoption of HB1530 also appears to have had a significant bias on the results, with the dummy variable proving to be significantly negatively associated with stock price $(\mathrm{p}<.01)$. As for macroeconomic variables, neither exchange rates nor the rate of GDP appear to have much effect on the results. However, interest rates are significantly positively associated $(\mathrm{p}<.01)$ with stock price. This is to be expected, since interest rates are used as an input for determining the discount rate used for bond valuation purposes. When interest rates increase, bond yields should follow, causing bond prices to fall. This could have the effect of a shift of invested funds from the bond markets to equity markets. The reverse should happen when interest rates fall, as did happen with central banks lowering interest rates to help revive recession hit economies in the follow-up to the Great Recession.

\subsubsection{Returns (Change) Regressions to test value-relevance of OCI and components}

Table 6.6 reported the results of the returns (change) regressions testing value-relevance of OCI and components. The coefficients on net income and OCI - both aggregate as well as components - were all found to be positively significant at conventional levels. Table 6.12 reports the results of running the same tests with additional control variables for size, debt-equity and industry dummies. For returns regressions, my variables are scaled by beginning of the period market value of equity. As such, using a per share amount could be problematic. To avoid econometric problems, I use the natural logarithm of total assets instead of total assets per share as a control for size.

The results of the basic regressions are found to be robust. OCI 1530 (and $\mathrm{OCI}_{130}$, not reported) is found to be positively associated with total returns at a $\mathrm{p}<.01$ level. The components of $\mathrm{OCI}_{1530}$ are also found to be significantly associated with returns at a $\mathrm{p}<.05$ or better level. Similar to the valuation regressions, size was found to be significantly associated $(\mathrm{p}<.01)$ with returns. Leverage (debt-equity) turned out to be not significantly associated with returns. Of the 
industry dummy variables, only mining turned out to be significantly associated with stock returns at a $\mathrm{p}<.01$ level.

Table 6-12: Returns (Change) Regressions to test value-relevance of OCI and components

\begin{tabular}{|c|c|c|c|c|c|c|c|c|c|}
\hline \multirow{3}{*}{$\begin{array}{l}\text { Dependent } \\
\text { Variable }\end{array}$} & \multicolumn{3}{|c|}{ Panel A } & \multicolumn{3}{|c|}{ Panel B } & \multicolumn{3}{|c|}{ Panel C } \\
\hline & \multicolumn{3}{|c|}{$\operatorname{Ret}_{i t}$} & \multicolumn{3}{|c|}{$\operatorname{Ret}_{i t}$} & \multicolumn{3}{|c|}{$\operatorname{Ret}_{i t}$} \\
\hline & Coeff. & t-stat & p-val & Coeff. & t-stat & p-val & Coeff. & t-stat & p-val \\
\hline Intercept & -.357 & -.799 & .424 & -.285 & .641 & .521 & 1.048 & 3.718 & .000 \\
\hline$N I_{i t}$ & .215 & 6.243 & .000 & .241 & 6.596 & .000 & .212 & 6.131 & .000 \\
\hline$O C I_{1530 i t}$ & .338 & 4.555 & .000 & & & & & & \\
\hline$H E D G E_{i t}$ & & & & .366 & 3.373 & .001 & .325 & 3.169 & .000 \\
\hline$S E C_{i t}$ & & & & 1.307 & 3.865 & .000 & 1.119 & 3.499 & .000 \\
\hline FOREX $_{i t}$ & & & & .239 & 2.256 & .024 & .295 & 2.940 & .003 \\
\hline PENADJ $J_{i t}$ & & & & 3.410 & 2.446 & .015 & 2.970 & 2.254 & .024 \\
\hline LnAssets & .059 & 4.081 & .000 & .056 & 3.875 & .000 & .051 & 3.816 & .000 \\
\hline Debt_Equity & -.001 & -1.275 & .202 & -.001 & -1.291 & .197 & -.000 & -.846 & .398 \\
\hline Mining & .130 & 3.944 & .000 & .125 & 3.814 & .000 & .116 & 3.745 & .000 \\
\hline Manufacturing & -.036 & -1.113 & .266 & -.035 & -1.068 & .286 & -.033 & -1.083 & .279 \\
\hline Financial & -.008 & -.209 & .835 & -.011 & -.279 & .781 & -.011 & -.305 & .760 \\
\hline Adoption & -.773 & -12.419 & .000 & -.754 & -12.134 & .000 & .108 & 1.665 & .096 \\
\hline ExchRate $_{t}$ & .681 & 1.422 & .155 & .601 & 1.261 & .208 & -1.082 & -3.580 & .000 \\
\hline$G D P t$ & -5.481 & -5.617 & .000 & -5.306 & -5.457 & .000 & & & \\
\hline$G D P_{t+1}$ & & & & & & & 12.653 & 12.774 & .000 \\
\hline IntRate $_{t}$ & 7.722 & 3.815 & .000 & 7.384 & 3.663 & .000 & -7.112 & -5.285 & .000 \\
\hline $\begin{array}{l}\text { No. of } \\
\text { observations }\end{array}$ & 1,097 & & & 1,097 & & & 1,097 & & \\
\hline F-Value & 79.106 & & & 63.939 & & & 80.884 & & \\
\hline Adjusted $R^{2}$ & .439 & & & .446 & & & .505 & & \\
\hline
\end{tabular}

That the timing of adoption of HB1530 caused significant bias was yet again supported by a significantly negative association $(\mathrm{p}<.01)$ for the adoption dummy. Among the controls for macroeconomic variables, interest rates (the rate of GDP) was found to be significantly positively (negatively) associated with stock returns at a $\mathrm{p}<.01$ level. While the positive significance for interest rates is understandable, given their direct relationship to stock prices, the negative significance for the rate of GDP is puzzling. Assuming semi-strong market efficiency, 
and the fact that macroeconomic data are generally published frequently enough for markets to be able to predict the following year's GDP rate, it may be argued that market participants revise their discount rates in anticipation of future economic activity. Therefore, it is possible that the correct control for GDP should be the expected GDP rate, rather than the current year's rate. To test for this, I replaced the GDP control with the following year's GDP rate.

The results, reported in Panel C of table 6.12, stay consistent for the components of OCI, size and industry. However, the sign for adoption changes from negative to positive, and its significance level diminishes to a $\mathrm{p}<.1$ level. Exchange rate, which had not been found significant earlier, is found to be negatively significant at $\mathrm{p}<.01$ level. The sign for interest rate changed from positive to negative $(\mathrm{p}<.01)$, and that for GDP from negative to positive $(\mathrm{p}<.01)$. Among the industry controls, only the mining sector was found to be significantly positively associated with stock returns.

I interpret these results in the following manner. The Canadian economy is primarily a resource driven economy, with Oil and Gas being a major economic sector. As table 6.13 shows, the time period under study witnessed a marked increase in crude oil prices, which could explain the positive significance for mining stocks. The Canadian dollar, being sensitive to the price of crude, also gained over the US Dollar. As a result it weakened the export competitiveness of other industries (note the negative association, although insignificant, for manufacturing and financial sectors). This explains the finding of negative significance for exchange rates. Also included in the study period is the time of the great recession followed by the financial crisis of 2007-2008, which led to a sharp decline in stock prices. Most central banks responded to the crisis by cutting interest rates to promote economic activity. The pullback in stock markets witnessed in 2009 could well have been initiated by the availability of cheap credit, thus explaining the negative association found between interest rates and stock returns. 
Table 6-13 Summary of key macroeconomic data

\begin{tabular}{|c|c|c|c|c|}
\hline Year & $\begin{array}{c}\text { Exchange Rate } \\
\text { CAD:USD }\end{array}$ & GDP Rate & $\begin{array}{c}\text { Bank of Canada } \\
\text { Interest Rate } \\
\text { (Average) }\end{array}$ & $\begin{array}{c}\text { Crude Oil Prices } \\
\text { (USD per barrel) }\end{array}$ \\
\hline 2001 & 0.6458 & $1.80 \%$ & $4.31 \%$ & 24.87 \\
\hline 2002 & 0.6368 & $2.90 \%$ & $2.71 \%$ & 24.97 \\
\hline 2003 & 0.7135 & $1.90 \%$ & $3.19 \%$ & 29.53 \\
\hline 2004 & 0.7683 & $3.10 \%$ & $2.50 \%$ & 38.13 \\
\hline 2005 & 0.8253 & $3.00 \%$ & $2.92 \%$ & 52.37 \\
\hline 2006 & 0.8818 & $2.80 \%$ & $4.31 \%$ & 64.33 \\
\hline 2007 & 0.9304 & $2.20 \%$ & $4.60 \%$ & 70.04 \\
\hline 2008 & 0.9381 & $0.70 \%$ & $3.21 \%$ & 101.41 \\
\hline 2009 & 0.8757 & $-2.80 \%$ & $0.65 \%$ & 60.29 \\
\hline 2010 & 0.9709 & $3.20 \%$ & $0.85 \%$ & 79.14 \\
\hline
\end{tabular}

\section{Sources:}

Exchange Rates: http://www.bankofcanada.ca/rates/exchange/exchange-rates-in-pdf/

GDP Data: http://data.worldbank.org/indicator/NY.GDP.MKTP.KD.ZG/countries?display=default

BoC Interest rates: http://www.bankofcanada.ca/rates/interest-rates/selected-historical-interest-rates/

Crude Oil prices: http://www.oecd-ilibrary.org/sites/factbook-2011-en/06/02/03/index.html

In conclusion, even after controlling for size, industry and certain key macroeconomic factors, the significant association observed between stock returns and aggregate $\mathrm{OCI}_{1530}$ as well as its components appears to support their value relevance.

\subsubsection{Alternative specification of normal earnings}

It will be recalled that I had used a 12 per cent rate of return to compute normal earnings, which I used to estimate abnormal earnings. A concern might be expressed that using an arbitrary rate of return produces potentially unreliable results. To test whether this is indeed the case, I use two alternative proxies for required rate of return: (i) the return on the average S\&P/TSX portfolio for the calendar year, and (ii) the average return calculated at the industry level. To calculate the latter metric, I first grouped the firms from a 2-digit SIC level into Mining, Manufacturing, Financial and Others. Then, I calculated the average return for each year within each group. The industry average returns should be viewed with caution, since they are 
not weighted for firm size (market capitalization, trading volume, etc). Table 6.14 presents the returns for the years 2001 through 2010.

Table 6-14: Annual Returns on the S\&P/TSX Index Portfolio and average industry level returns for 2001-2010

\begin{tabular}{|c|c|c|c|c|c|}
\hline & TSX $^{30}$ & Mining & Manufacturing & Financial & Other \\
\hline 2001 & $(0.1260)$ & 0.8320 & 0.1568 & 0.0870 & $(0.2366)$ \\
\hline 2002 & $(0.1240)$ & 0.3223 & $(0.3423)$ & $(0.1342)$ & $(0.3189)$ \\
\hline 2003 & 0.2670 & 1.6939 & 0.0599 & 0.4035 & 0.8270 \\
\hline 2004 & 0.1450 & 0.8260 & $(0.1485)$ & 0.1843 & 0.2548 \\
\hline 2005 & 0.2410 & 1.8820 & $(0.2118)$ & 0.3438 & 0.0612 \\
\hline 2006 & 0.1730 & 0.5901 & $(0.0131)$ & 0.0697 & 0.1957 \\
\hline 2007 & 0.0980 & 0.0651 & $(0.6094)$ & $(0.1187)$ & 0.0677 \\
\hline 2008 & $(0.3300)$ & $(0.4248)$ & $(0.7921)$ & $(0.3685)$ & $(0.3765)$ \\
\hline 2009 & 0.3510 & 1.1993 & 1.7166 & 0.5292 & 0.2124 \\
\hline 2010 & 0.1760 & 0.3662 & 1.0329 & 0.0382 & 0.1549 \\
\hline
\end{tabular}

Source: Self calculated, except for TSX return data

During the ten year period, the broader S\&P/TSX index delivered negative returns during three years. In contrast, the mining sector experienced negative returns only once, that too during the financial crisis in 2008. The manufacturing sector delivered negative returns in five out of the ten years, indicating industry level difficulties. The financial sector reported negative returns in 2002, and then in 2007 and 2008. The latter two years is reflective of the difficult times the financial sector experienced during the financial crisis. The other industries broadly followed the S\&P/TSX sector.

A third specification for normal (or expected) earnings could be the previous year's earnings. This approach was used in early capital markets research, including the seminal work of Ball and Brown (1968).

\footnotetext{
${ }^{30}$ I obtained the data on the S\&P/TSX portfolio returns from http://www.ndir.com/cgibin/PeriodicTableofAnnualReturns.cgi
} 
Table 6.15 reports the Pearson correlation coefficients for the three measures of abnormal earnings. AbnEarn is the measure I used for my earlier tests of forecasting relevance and predictability, calculated as the difference between actual earnings per share and expected earnings (beginning book value per share multiplied by 12 per cent). AETSX is the first alternative measure, calculated as the difference between actual earnings per share and expected earnings (beginning book value per share multiplied by the average S\&P/TSX return for the calendar year). AEInd is the second alternative measure, calculated as the difference between actual earnings per share and expected earnings (beginning book value per share multiplied by the average Industry return for the calendar year). AENI is the third alternative measure, which is equal to the difference between current net income per share and the lagged net income per share. As table 6.15 shows all of the alternative measures of abnormal earnings are significantly correlated with each other.

Table 6-15: Correlation matrix and Pearson Coefficients for various estimates of abnormal earnings

\begin{tabular}{|ll|c|c|c|c|}
\hline Correlations $^{\mathrm{a}}$ & AbnEarn & AETSX & AEInd & AENI \\
\hline \multirow{2}{*}{ AbnEarn } & Pearson Correlation & 1.000 & $.321^{* *}$ & $.228^{* *}$ & $.502^{* *}$ \\
& Sig. (1-tailed) & & .000 & .000 & .000 \\
\hline \multirow{2}{*}{ AETSX } & Pearson Correlation & $.321^{* *}$ & 1.000 & $.873^{* *}$ & $.315^{* *}$ \\
& Sig. (1-tailed) & .000 & & .000 & .000 \\
\hline \multirow{2}{*}{ AEInd } & Pearson Correlation & $.228^{* *}$ & $.873^{* *}$ & 1.000 & $.235^{* *}$ \\
& Sig. (1-tailed) & .000 & .000 & & .000 \\
\hline AENI & Pearson Correlation & $.502^{* *}$ & $.315^{* *}$ & $.235^{* *}$ & 1.000 \\
& Sig. (1-tailed) & .000 & .000 & .000 & \\
\hline
\end{tabular}

**. Correlation is significant at the 0.01 level (1-tailed).

a. Listwise $\mathrm{N}=1074$

6.3.2.1 Regressions testing the ability of OCI and its components to forecast future abnormal earnings

To test for the ability of OCI or its components to forecast these alternative measures of abnormal earnings, I run the following variants of model 1. The results are summarized in table 6.16. I decided to include lagged PENADJ as a precaution against possible omitted variables problem. 


$$
\begin{aligned}
& \text { AETSX }_{i t}=\alpha_{0}+\alpha_{1} \text { AETSX }_{i t-1}+\alpha_{2} \text { OCI }_{1530 \text { it-1 }}+\varepsilon_{i t} \\
& \text { AETSX }_{i t}=\alpha_{0}+\alpha_{1} \text { AETSX }_{i t-1}+\alpha_{2} \text { HEDGE }_{i t-1}+\alpha_{3} \text { SEC }_{i t-1}+\alpha_{4} \text { FOREX }_{i t-1}+\alpha_{5} \text { PENADJ }_{i t-1}+\varepsilon_{i t}[1 \mathrm{~g}] \\
& \text { AEInd }_{i t}=\alpha_{0}+\alpha_{1} \text { AEInd }_{i t-1}+\alpha_{2} \text { OCI }_{1530 i t-1}+\varepsilon_{i t} \\
& \text { AEInd }_{i t}=\alpha_{0}+\alpha_{1} \text { AbnInd }_{i t-1}+\alpha_{2} \text { HEDGE }_{i t-1}+\alpha_{3} \text { SEC }_{i t-1}+\alpha_{4} \text { FOREX }_{i t-1}+\alpha_{5} \text { PENADJ }_{i t-1}+\varepsilon_{i t}[1 \mathrm{i}] \\
& \text { AENI }_{i t}=\alpha_{0}+\alpha_{1} \text { AENI }_{i t-1}+\alpha_{2} \text { OCI }_{1530 \text { it-1 }}+\varepsilon_{i t} \\
& \text { AENI }_{i t}=\alpha_{0}+\alpha_{1} \text { AENI }_{i t-1}+\alpha_{2} \text { HEDGE }_{i t-1}+\alpha_{3} \text { SEC }_{i t-1}+\alpha_{4} \text { FOREX }_{i t-1}+\alpha_{5} \text { PENADJ }_{i t-1}+\varepsilon_{i t}[1 \mathrm{k}]
\end{aligned}
$$

\section{Where}

AETSX $_{i t}$ the difference between the actual earnings per share and the expected earnings, specified as beginning book value per share multiplied by the average S\&P/TSX portfolio return for the calendar year.

AEInd $_{i t} \quad$ the difference between the actual earnings per share and the expected earnings, specified as beginning book value per share multiplied by the average industry return for the calendar year.

AENI $_{i t}$ the difference between the actual earnings per share and the expected earnings, specified as previous year's earnings per share.

$H E D G E_{i t-1}$ the change in the fair value of cash flow hedges under Canadian the fiscal year $\mathrm{t}-1$;

$S E C_{i t-1} \quad$ the change in the fair value of available-for-sale investments under Canadian GAAP for the fiscal year $\mathrm{t}-1$; and

FOREX $X_{\text {it -1 }}$ change in cumulative foreign currency translation adjustment under Canadian GAAP for the fiscal year $\mathrm{t}-1$.

PENADJ $J_{i t-1}$ the per share change in additional minimum pension liability in excess of unrecognized prior service costs under SFAS 130 for the fiscal year t-1

$O_{153, i t-1}$ the sum of $H E D G E_{i t-1}$ (fair value changes in cash flow hedges), $S E C_{i t-1}$ (fair value changes in available for sale investments) and FOREX $X_{\text {it-1 }}$ (changes in cumulative foreign currency translation adjustment) following Canadian GAAP. 
Table 6-16: Regression to test the ability of OCI and its components to forecast future abnormal earnings

\begin{tabular}{|c|c|c|c|c|c|c|}
\hline Dependent & \multicolumn{2}{|c|}{$\operatorname{AETSX}_{i t}$} & \multicolumn{2}{|c|}{${ }_{A E I n d}$} & \multicolumn{2}{|c|}{$A E N I_{i t}$} \\
\hline $\begin{array}{l}\text { Independent } \\
\text { Variables }\end{array}$ & Model 1f & Model 1g & Model 1h & Model 1i & Model 1i & Model $1 \mathrm{j}$ \\
\hline Intercept & $\begin{array}{l}.012 \\
{[t=.084} \\
p=.933]\end{array}$ & $\begin{array}{l}.000 \\
{[\mathrm{t}=.002} \\
\mathrm{p}=.999]\end{array}$ & $\begin{array}{l}-1.520 \\
{[t=-5.422} \\
p=.000]\end{array}$ & $\begin{array}{l}-1.441 \\
{[t=-5.296} \\
p=.000]\end{array}$ & $\begin{array}{l}-.147 \\
{[t=-2.247} \\
p=.025]\end{array}$ & $\begin{array}{l}-.153 \\
{[t=-2.381} \\
p=.017]\end{array}$ \\
\hline $\operatorname{AETSX}_{i t-1}$ & $\begin{array}{l}-.353 \\
{[t=-15.979} \\
p=.000]\end{array}$ & $\begin{array}{l}-.298 \\
{[t=-10.894} \\
p=.000]\end{array}$ & & & & \\
\hline${ }_{A E I n d}{ }_{i t-1}$ & & & $\begin{array}{l}-.273 \\
{[t=-9.513} \\
p=.000]\end{array}$ & $\begin{array}{l}-.154 \\
{[t=-4.939} \\
p=.000]\end{array}$ & & \\
\hline$\overline{A E N I_{i t-1}}$ & & & $\begin{array}{l}-.273 \\
{[t=-9.513} \\
p=.000]\end{array}$ & $\begin{array}{l}-.154 \\
{[t=-4.939} \\
p=.000]\end{array}$ & $\begin{array}{l}-.467 \\
{[t=-18.606} \\
p=.000]\end{array}$ & $\begin{array}{l}-.466 \\
{[t=-18.482} \\
p=.000]\end{array}$ \\
\hline$O C I_{1530 i t-1}$ & $\begin{array}{l}.212 \\
{[t=1.708} \\
p=.088]\end{array}$ & & $\begin{array}{l}1.278 \\
{[t=5.557} \\
p=.000]\end{array}$ & & $\begin{array}{l}.821 \\
{[t=17.030} \\
p=.000]\end{array}$ & \\
\hline$H E D G E_{i t-1}$ & & $\begin{array}{l}.667 \\
{[t=3.414} \\
p=.001]\end{array}$ & & $\begin{array}{l}.600 \\
{[t=1.629} \\
p=.104]\end{array}$ & & $\begin{array}{l}1.077 \\
{[t=12.502} \\
p=.000]\end{array}$ \\
\hline$S E C_{i t-1}$ & & $\begin{array}{l}1.119 \\
{[\mathrm{t}=3.815} \\
\mathrm{p}=.000]\end{array}$ & & $\begin{array}{l}5.146 \\
{[\mathrm{t}=10.082} \\
\mathrm{p}=.000]\end{array}$ & & $\begin{array}{l}1.134 \\
{[t=11.361} \\
p=.000]\end{array}$ \\
\hline FOREX $X_{i t-1}$ & & $\begin{array}{l}-.461 \\
{[t=-2.554} \\
p=.011]\end{array}$ & & $\begin{array}{l}-.038 \\
{[t=-.111} \\
p=.911]\end{array}$ & & $\begin{array}{l}.405 \\
{[t=5.064} \\
p=.000]\end{array}$ \\
\hline$P E N A D J_{i t-1}$ & & $\begin{array}{l}.724 \\
{[t=.424} \\
p=.672]\end{array}$ & & $\begin{array}{l}2.698 \\
{[t=.840} \\
p=.401]\end{array}$ & & $\begin{array}{l}-1.868 \\
{[t=2.472} \\
p=.014]\end{array}$ \\
\hline $\begin{array}{l}\text { No. of } \\
\text { observations } \\
\text { F-Value } \\
\text { Adjusted } R^{2} \\
\end{array}$ & $\begin{array}{l}1074 \\
191.191 \\
.262 \\
\end{array}$ & $\begin{array}{l}1074 \\
\\
83.478 \\
.278 \\
\end{array}$ & $\begin{array}{l}1074 \\
\\
104.200 \\
.161 \\
\end{array}$ & $\begin{array}{l}1074 \\
\\
58.726 \\
.216 \\
\end{array}$ & $\begin{array}{l}1074 \\
\\
343.504 \\
.390 \\
\end{array}$ & $\begin{array}{l}1074 \\
152.897 \\
.414 \\
\end{array}$ \\
\hline
\end{tabular}

As reported in table 6.16, using AETSX, AEInd and AENI as alternative measures of abnormal earnings yield considerably higher adjusted r-squareds (16.1 per cent to 41.4 per cent) than for AbnEarn (11.5 per cent to 15.5 per cent). The results for the alternative measures are broadly comparable with those for AbnEarn.

When AETSX is used as a proxy for abnormal earnings (models $1 \mathrm{f}$ and $1 \mathrm{~g}$ ), the results remain qualitatively similar to those reported for AbnEarn (table 6.3). Lagged aggregate OCI (model 1f), and HEDGE and SEC (model 1g) are significantly positively associated with 
AETSX. However, the sign of the coefficient on lagged AETSX is negative $(\mathrm{p}<.01)$, most likely due to the fact that the abnormal earnings are conditional on S\&P/TSX returns, which were negative during 2008 in the midst of the financial crisis. Another difference is that although lagged $\mathrm{OCI}_{1530}$ remains significant, its significance drops to a $\mathrm{p}<.1$ level. Further, lagged FOREX is found to be negatively significantly associated with AETSX at a p<.05 level.

Lagged PENADJ did not turn out to be a significant predictor of either AETSX or AEInd. Lagged aggregate $\mathrm{OCI}_{1530}$ is found to be significantly positively associated with AEInd (models 1h) at a $<<.01$ level. Lagged AEInd is significantly, but negatively, associated with AEInd at a $\mathrm{p}<.01$ level (models $1 \mathrm{~h}$ and $1 \mathrm{i}$ ). However, among the components of $\mathrm{OCI}_{1530}$, only lagged SEC proves significantly positively associated with AEInd.

In contrast, when AENI is used as a measure for abnormal earnings, lagged values of $\mathrm{OCI}_{1530}$ and all of its components are found to be significantly positively associated with it at a $\mathrm{p}<.01$ level. Lagged AENI is also found to be significantly $(\mathrm{p}<.01)$, but negatively, associated with AENI. Further, PENADJ, which was not found to be associated with either AETSX or AEInd, turns out to be significantly negatively associated with AENI at a $\mathrm{p}<.05$ level.

In conclusion, the ability of $\mathrm{OCI}_{1530}$, and some of its components, to forecast future abnormal earnings is robust to multiple alternative specifications of abnormal earnings.

\subsubsection{Regressions to test predictability of OCI}

The preceding results suggest that the finding of forecasting relevance for OCI is not driven by my measure of abnormal earnings. However, as an additional precaution, I also test for predictability of OCI and its components using the alternative measures of abnormal earnings by running the following variants of model 2. The results are presented in table 6.16 which follows.

$$
\begin{aligned}
& \text { OCI }_{1530 i t}=\beta_{0}+\beta_{1} \text { AETSX }_{i t-1}+\beta_{2} \text { OCI }_{1530 \text { it- } 1}+\varepsilon_{i t} \\
& \text { OCI }_{1530 i t}=\beta_{0}+\beta_{1} \text { AETSX }_{i t-1}+\beta_{2} \text { HEDGE }_{i t-1}+\beta_{3} \text { SEC }_{i t-1}+\beta_{4} \text { FOREX }_{i t-1}+\beta_{5} \text { PENADJ }_{i t-1}+\varepsilon_{i t} \\
& \text { OCI }_{1530 i t}=\beta_{0}+\beta_{1} \text { AEInd }_{i t-1}+\beta_{2} \text { OCI }_{1530 ~ i t-1}+\varepsilon_{i t} \\
& \text { OCI }_{1530 i t}=\beta_{0}+\beta_{1} \text { AEInd }_{i t-1}+\beta_{2} \text { HEDGE }_{i t-1}+\beta_{3} \text { SEC }_{i t-1}+\beta_{4} \text { FOREX }_{i t-1}+\beta_{5} \text { PENADJ }_{i t-1}+\varepsilon_{i t}
\end{aligned}
$$


$O C I_{1530 i t}=\beta_{0}+\beta_{1} A E N I_{t-1}+\beta_{2} O C I_{1530 \text { it- } 1}+\varepsilon_{i t}$

$\mathrm{OCI}_{1530 i t}=\beta_{0}+\beta_{1} \mathrm{AENI}_{i t-1}+\beta_{2} \mathrm{HEDGE}_{i t-1}+\beta_{3} \mathrm{SEC}_{i t-1}+\beta_{4} \mathrm{FOREX}_{i t-1}+\beta_{5}$ PENADJ $_{i t-1}+\varepsilon_{i t}$

where subscripts $i$ and $t$ denote the firm $i$ and year $t$ respectively, and the variables are as defined earlier.

As reported in table 6.17, the tests for predictability of $\mathrm{OCI}_{1530}$ and its components using alternative measures of abnormal earnings yield results which are qualitatively identical to those reported in table 6.4. The lagged values of the alternative measures of abnormal earnings are positively significantly associated with $\mathrm{OCI}_{1530}$. Lagged values of aggregate $\mathrm{OCI}_{1530}$ (models 2e and $2 \mathrm{~g}$ ) and those of its components, HEDGE, SEC, and FOREX (models $2 \mathrm{f}$ and $2 \mathrm{~h}$ ), are all significantly negatively associated with $\mathrm{OCI}_{1530}$ at a $\mathrm{p}<.01$ level. Lagged PENADJ is not found to be significantly associated with $\mathrm{OCI}_{1530}$. These results are consistent with those reported in table 6.4, where AbnEarn was used as the measure for abnormal earnings. These results confirm that my finding of predictability for OCI is not affected by my measure of abnormal earnings. 
Table 6-17: Regressions to test predictability of OCI and components

\begin{tabular}{|c|c|c|c|c|c|c|}
\hline Dependent Variable & \multicolumn{2}{|c|}{$\mathrm{OCI}_{1530 \mathrm{it}}$} & \multicolumn{2}{|c|}{$O C I_{1530 i t}$} & \multicolumn{2}{|c|}{$\mathrm{OCI}_{1530 \mathrm{it}}$} \\
\hline Independent Variables & Model 2e & Model 2f & Model 2g & Model 2h & Model 2i & Model 2j \\
\hline Intercept & $\begin{array}{l}.048 \\
{[\mathrm{t}=-1.409} \\
\mathrm{p}=.159]\end{array}$ & $\begin{array}{l}-.045 \\
{[\mathrm{t}=-1.391} \\
\mathrm{p}=.164]\end{array}$ & $\begin{array}{l}.008 \\
{[t=-.219} \\
p=.827]\end{array}$ & $\begin{array}{l}-.024 \\
{[t=-.738} \\
p=.461]\end{array}$ & $\begin{array}{l}.015 \\
{[t=-.393} \\
p=.695]\end{array}$ & $\begin{array}{l}-. .037 \\
{[\mathrm{t}=-1.100} \\
\mathrm{p}=.271]\end{array}$ \\
\hline $\operatorname{AETSX}_{i t-1}$ & $\begin{array}{l}.089 \\
{[t=17.119} \\
p=.000]\end{array}$ & $\begin{array}{l}.054 \\
{[t=8.853} \\
p=.000]\end{array}$ & & & & \\
\hline AEInd $_{i t-1}$ & & & $\begin{array}{l}.042 \\
{[t=11.334} \\
p=.000]\end{array}$ & $\begin{array}{l}.020 \\
{[t=5.164} \\
p=.000]\end{array}$ & & \\
\hline$A E N I_{i t-1}$ & & & & & $\begin{array}{l}.037 \\
{[t=2.512} \\
p=.012]\end{array}$ & $\begin{array}{l}-.016 \\
{[t=-1.187} \\
p=.235]\end{array}$ \\
\hline $\mathrm{OCI}_{1530 i t-1}$ & $\begin{array}{l}-.700 \\
{[t=-24.057} \\
p=.000]\end{array}$ & & $\begin{array}{l}-.801 \\
{[t=-26.819} \\
p=.000]\end{array}$ & & $\begin{array}{l}-.945 \\
{[t=-33.306} \\
p=.000]\end{array}$ & \\
\hline$H E D G E_{i t-1}$ & & $\begin{array}{l}-.391 \\
{[t=-8.959} \\
p=.000]\end{array}$ & & $\begin{array}{l}-.409 \\
{[t=-9.142} \\
p=.000]\end{array}$ & & $\begin{array}{l}-.438 \\
{[t=-9.752} \\
p=.000]\end{array}$ \\
\hline$S E C_{i t-1}$ & & $\begin{array}{l}-1.294 \\
{[t=-18.458} \\
p=.000]\end{array}$ & & $\begin{array}{l}-1.551 \\
{[t=-25.055} \\
p=.000]\end{array}$ & & $\begin{array}{l}-1.748 \\
{[t=-33.567} \\
p=.000]\end{array}$ \\
\hline FOREX $X_{i t-1}$ & & $\begin{array}{l}.729 \\
{[t=-18.096} \\
p=.000]\end{array}$ & & $\begin{array}{l}.735 \\
{[t=-17.811} \\
p=.000]\end{array}$ & & $\begin{array}{l}-.743 \\
{[t=-17.828} \\
p=.000]\end{array}$ \\
\hline PENADJ ${ }_{i t-1}$ & & $\begin{array}{l}.102 \\
{[t=.268} \\
p=.789]\end{array}$ & & $\begin{array}{l}.039 \\
{[t=.101} \\
p=.920]\end{array}$ & & $\begin{array}{l}.072 \\
{[t=.183} \\
p=.855]\end{array}$ \\
\hline $\begin{array}{l}\text { No. of observations } \\
\text { F-Value } \\
\text { Adjusted } R^{2}\end{array}$ & $\begin{array}{l}1074 \\
860.581 \\
.616\end{array}$ & $\begin{array}{l}1074 \\
415.160 \\
.659\end{array}$ & $\begin{array}{l}1074 \\
692.118 \\
.563\end{array}$ & $\begin{array}{l}1074 \\
386.802 \\
.643\end{array}$ & $\begin{array}{l}1074 \\
567.107 \\
.513\end{array}$ & $\begin{array}{l}1074 \\
372.948 \\
.634\end{array}$ \\
\hline
\end{tabular}

\subsubsection{Testing the ability of OCI and components to predict future net income and operating cash flows}

I used value relevance and association with analysts’ earnings forecasts as indicators of decision usefulness. However, the concept of decision usefulness can be conceived of in other ways as well. For example, it is common to describe the objective of financial reporting in terms of predicting future cash flows. There is a sizeable literature examining whether current earnings items can predict future cash flows (Orpurt and Zang 2009; Dechow et al. 1998; Kim and Kross 2005; Finger 1994; Barth et al. 2001b; Sloan 1996). Sloan (1996) showed that net income can be decomposed into two components - operating cash flows, and accruals. Operating cash flows are 
expected to be more persistent, whereas accruals are transitory, and expected to reverse in future. Furthermore, given that accruals are transitory, they should not be able to predict future cash flows.

Jones and Smith (2011) found that OCI is able to predict future income from continuing operations (i.e. net income minus special, or non-recurring, items) and operating cash flows. Their finding provides additional, albeit indirect, evidence that OCI items are not transitory. To test whether OCI is able to predict future net income and cash flows for my sample, I ran the following regressions. Results are tabulated in table 16.18 which follows.

$$
\begin{aligned}
& N I / S_{i t}=\eta_{0}+\eta_{1} N I / S_{i t-1}+\eta_{2} O C I_{1530 i t-1}+\varepsilon_{i t} \\
& N I / S_{i t}=\eta_{0}+\eta_{1} N I / S_{i t-1}+\eta_{2} H E D G E_{i t-1}+\eta_{3} S E C_{i t-1}+\eta_{4} F_{R O R E X} i t-1+\eta_{5} \text { PENADJ }_{i t-1} \\
& +\varepsilon_{i t} \\
& \text { OCF } / S_{i t}=\tau_{0}+\tau_{1} O C F / S_{i t-1}+\tau_{2} \text { Accruals } / S_{i t-1}+\tau_{3} O C I_{1530 i t-1}+\varepsilon_{i t} \\
& O C F / S_{i t}=\tau_{0}+\tau_{1} O C F / S_{i t-1}+\tau_{2} \text { Accruals } / S_{i t-1}+\tau_{3} H E D G E_{i t-1}+\tau_{4} S E C_{i t-1}+\tau_{5} F O R E X_{i t-1}+\tau \\
& { }_{6} P E N A D J_{i t-1}+\varepsilon_{i t}
\end{aligned}
$$

where,

$N I / S_{i t} \quad$ net income per share after extraordinary items and discontinued operations for the fiscal year t;

$O C F / S_{i t} \quad$ operating cash flow per share for the fiscal year t;

Accruals $/ S_{i t}$ per share amount of accruals, calculated as the difference between Operating Cash Flow per share and Net Income per share.

Other variables are as defined in earlier sections

As reported in table 6.18, lagged aggregate $\mathrm{OCI}_{1530}$ is significantly positively associated with future net income at a $\mathrm{p}<.01$ level. Each of its components is also significantly positively associated with future net income at a $\mathrm{p}<.01$ level. Lagged PENADJ is also significantly, but negatively, associated with future net income. Lagged net income is also highly significantly, and positively, associated with future net income, indicating a high degree of persistence of net 
income. Furthermore, consistent with Sloan (1996), lagged operating cash flows (OCF) are highly significantly associated with future OCF. Consistent with Jones and Smith (2011), I also find lagged aggregate $\mathrm{OCI}_{1530}$ to be incrementally predictive of future OCF. However, amongst its components, only unrealized gains and losses on available for sale securities (SEC) is significantly associated with future OCFs.

Table 6-18: Regressions to test the ability of OCI and components to forecast future net income and operating cash flows

\begin{tabular}{|c|c|c|c|c|}
\hline Dependent Variable & \multicolumn{2}{|c|}{$N I / S_{i t}$} & \multicolumn{2}{|c|}{$O C F / S_{i t}$} \\
\hline Independent Variables & Model 8a & Model 8b & Model 9a & Model 9b \\
\hline Intercept & $\begin{array}{l}.313 \\
{[t=3.617} \\
p=.000]\end{array}$ & $\begin{array}{l}.245 \\
{[t=2.881} \\
p=.004]\end{array}$ & $\begin{array}{l}1.071 \\
{[\mathrm{t}=12.366} \\
\mathrm{p}=.000]\end{array}$ & $\begin{array}{l}1.011 \\
{[t=10.820} \\
p=.000]\end{array}$ \\
\hline$N I / S_{i t-1}$ & $\begin{array}{l}.572 \\
{[t=20.676} \\
p=.000]\end{array}$ & $\begin{array}{l}.598 \\
{[t=21.676} \\
p=.000]\end{array}$ & & \\
\hline$O C F / S_{i t-1}$ & & & $\begin{array}{l}.468 \\
{[t=21.178} \\
p=.000]\end{array}$ & $\begin{array}{l}.489 \\
{[t=20.624} \\
p=.000]\end{array}$ \\
\hline Accruals/S $S_{i t-1}$ & & & $\begin{array}{l}-.001 \\
{[\mathrm{t}=-.259} \\
\mathrm{p}=.796]\end{array}$ & $\begin{array}{l}.001 \\
{[t=-.243} \\
p=.808]\end{array}$ \\
\hline$O \mathrm{CI}_{1530 \mathrm{it}-1}$ & $\begin{array}{l}.340 \\
{[t=6.987} \\
p=.000]\end{array}$ & & $\begin{array}{l}.307 \\
{[t=7.615} \\
p=.000]\end{array}$ & \\
\hline$H E D G E_{i t-1}$ & & $\begin{array}{l}.872 \\
{[t=8.305} \\
p=.000]\end{array}$ & & $\begin{array}{l}.141 \\
{[t=1.396} \\
p=.163]\end{array}$ \\
\hline$S E C_{i t-1}$ & & $\begin{array}{l}.216 \\
{[t=2.918} \\
p=.004]\end{array}$ & & $\begin{array}{l}.559 \\
{[t=8.356} \\
p=.000]\end{array}$ \\
\hline FOREX $X_{i t-1}$ & & $\begin{array}{l}.269 \\
{[t=2.677} \\
p=.008]\end{array}$ & & $\begin{array}{l}.055 \\
{[t=-.569} \\
p=.569]\end{array}$ \\
\hline$P E N A D J_{i t-1}$ & & $\begin{array}{l}-2.397 \\
{[t=-2.553} \\
p=.011]\end{array}$ & & $\begin{array}{l}-1.223 \\
{[t=-1.357} \\
p=.175]\end{array}$ \\
\hline $\begin{array}{l}\text { No. of observations } \\
\text { F-Value } \\
\text { Adjusted } R^{2}\end{array}$ & $\begin{array}{l}1077 \\
371.265 \\
.408 \\
\end{array}$ & $\begin{array}{l}972 \\
170.199 \\
.466 \\
\end{array}$ & $\begin{array}{l}1077 \\
151.277 \\
.295 \\
\end{array}$ & $\begin{array}{l}972 \\
72.903 \\
.308 \\
\end{array}$ \\
\hline
\end{tabular}

How do we interpret these results? It would appear that it decision usefulness is defined in terms of the ability to predict future net income, aggregate $\mathrm{OCI}_{1530}$ and its components are all 
decision useful. In fact, even PENADJ is able to predict future net income. However, if we describe decision usefulness in terms of the ability to predict future operating cash flows, then, although aggregate $\mathrm{OCI}_{1530}$ appears to be able to do so, only one of its components, namely SEC, is able to predict future OCFs. The implication of this latter finding is that not all components of OCI are useful for decision making. 


\section{Chapter Seven: Discussion, Limitations and Future Research}

\subsection{Discussion of the contributions and limitations of this study}

Motivated by an absence of consensus in the literature on the value relevance of comprehensive income and its components, as well as the recent availability of actually reported data which helps mitigate potential measurement error, this study is an empirical investigation of the decision usefulness of mandatory comprehensive income reporting in Canada. HB1530 Comprehensive Income became effective for firm fiscal years starting October 1, 2006 and later. In its discussion of the basis for conclusions for the new standard, the AcSB did not provide compelling economic justification for the standard. The new standard appeared to have been adopted as an effort to align Canadian accounting with that in the U.S. However, one of the reasons cited for its introduction in Canada was that the proposed standard would "help make certain gains and losses more transparent to financial statement users” (CICA 2005a). This, of course, begged the question whether such disclosure was useful.

In this study I address the above question by using a market returns and valuation model to inquire whether other comprehensive income and its components are significantly associated with market value of equity and with stock returns, after controlling for book value, net income and other factors. I find that aggregate OCI, and some of its components are significantly associated with stock price. Also, aggregate OCI and its components are significantly associated with stock returns, although the significance for FOREX disappears when controls for negative net income (i.e. loss) and post-2006 period are added. My findings are qualitatively similar to those documented by Chambers et al (2007), Kanagaretnam et al (2009) and Jones and Smith (2011). However, through additional robustness tests, I demonstrate that the significant association with stock price that was observed for individual components of OCI vanishes when we control for size. I also show that Dhaliwal et al's (1999) finding that industry differences matter when considering the usefulness of comprehensive income, still holds for valuation purposes. 


\subsubsection{Contributions}

The primary contribution of this study is in its systematic examination of the value relevance of OCI. Although it has been considered by researchers for a long time to be transitory earnings, I draw upon Ohlson's (1999) propositions about the properties of transitory earnings to demonstrate that OCI has the ability to forecast future abnormal earnings, as well as predictability. For my empirical examination I apply Ohlson’s residual income valuation model incorporating transitory earnings. In specifically testing whether OCI matches Ohlson's (1999) characterization of transitory earnings as unpredictable, and valuation- and forecast-irrelevant, this is one of the very few studies that explicitly test the assumptions of Ohlson's theoretical model before applying its residual income specification to value relevance type tests. I tested OCI and its components for forecasting relevance and predictability, two attributes of transitory earnings specified by Ohlson (1999) as vital for an earnings item to be value relevant. I conclude that OCI and two of its components, namely SEC and HEDGE, are able to forecast future abnormal earnings, and are able to predict future OCI. The FOREX variable is not relevant for forecasting abnormal earnings, but is significantly able to predict future OCI. Ohlson (1999) predicted that if an earnings component is persistent, and is able to forecast abnormal earnings, it would also be value relevant. My results support Ohlson's (1999) prediction. However, my results do not concur with Ohlson's characterization of OCI as being transitory. I do not claim that Ohlson's analysis is incorrect. However, I would submit that perhaps OCI should not be considered to be transitory earnings. In this respect, my study echoes the results of Jones and Smith (2011).

A basic premise underlying the Conceptual Framework for Accounting is that accounting information is useful for decision making. But what makes the information decision useful? According to the discussion of qualitative characteristics of useful information presented in Section 1000 Financial Statement Concepts, accounting information is considered to be useful if it possesses the primary characteristics of relevance, reliability, understandability and comparability (paragraphs 18-23). Comparability is generally achieved through the application of generally accepted accounting principles and specific accounting standards. Understandability is assumed to exist where users "have a reasonable understanding of business 
and economic activities and accounting, together with a willingness to study the information with reasonable diligence” (para 19). Reliability is broadly assured through audit. This is why most extant studies pertaining to decision usefulness tend to focus on the issue of relevance. This study goes beyond the issue of value relevance in its exposition of the concept of decision usefulness. Through multiple specifications, of which value relevance is one, I provide a well rounded body of evidence on the issue of decision usefulness of OCI. I provide evidence on the predictive ability of OCI and its components, i.e. their ability to predict future income and cash flows (para 20(a)).

I also provide evidence on whether information contained in OCI is used by analysts in their earnings forecasts, and whether such information helps analysts make better forecasts. In doing so, this study contributes to the literature studying analysts' forecasts in presenting evidence of the association between OCI and its components and analysts' earnings forecasts. I show that information on OCI appears to be used by analysts, and that this information does have the effect of reducing analysts’ forecast errors.

\subsubsection{Limitations}

Similar to other value relevance studies, this study is based on the assumption of semi-strong market efficiency. To the extent that this is an untenable assumption, it may be considered one of the limitations of this study. However, as Ball (2009), writing in response to criticism of the efficient market hypothesis in the wake of the financial crisis of 2007-2008 argues, "The impact of the theory of efficient markets has proven to be durable, and seems likely to continue to be so, despite its inevitable and painfully obvious limitations” (p. 16).

Another limitation of this study is the time period to which my data pertains. The years 20072008 saw the precipitation of what has been called the Great Recession, a period of financial crisis of a magnitude that is perhaps not witnessed in decades. Furthermore, the interval it studies is rather short, and it may well be hard to discern stable relationships. O’Hanlon and Pope (1999) noted that due to timing differences between the recognition of events in stock returns (assuming market efficiency) and their recognition by the accounting system, tests based on annual stock returns and annual accounting flows have low power in detecting value-relevance. 
Moreover, it may also be the case that investors take time before they start incorporating additional information, such as that presented in OCI. Hirst and Hopkins' (1998) and Maines and McDaniel's (2000) experimental behavioural research suggests that although certain disclosures under comprehensive income (e.g. fair value changes in available for sale securities) does help analysts' judgments, some of them may well consider the information to be "a simple reformatting of the financial statements" (Hirst and Hopkins 1998) (emphasis in the original).

A potential limitation of this study is that the results could have been impacted by the potentially confounding effects of the macro-economic environment which saw major global economies including Canada suffer from a sharp and prolonged recession. What is special about the post 2006 period? Recall that I used the post-2006 period to correspond to the period of time when HB1530 was in effect. However, as can seen from Figures 3 and 4 below, this period of time also corresponded with a period of sustained stock market growth (up to the latter half of the year 2008) followed by a sharp decline that almost halved the index capitalization. This decline in stock prices was preceded by a series of events that are collectively referred to as the financial crisis of 2007-2008.

Figure 3: S\&P/TSX Index for the period January 1, 2005 - December 31, 2011

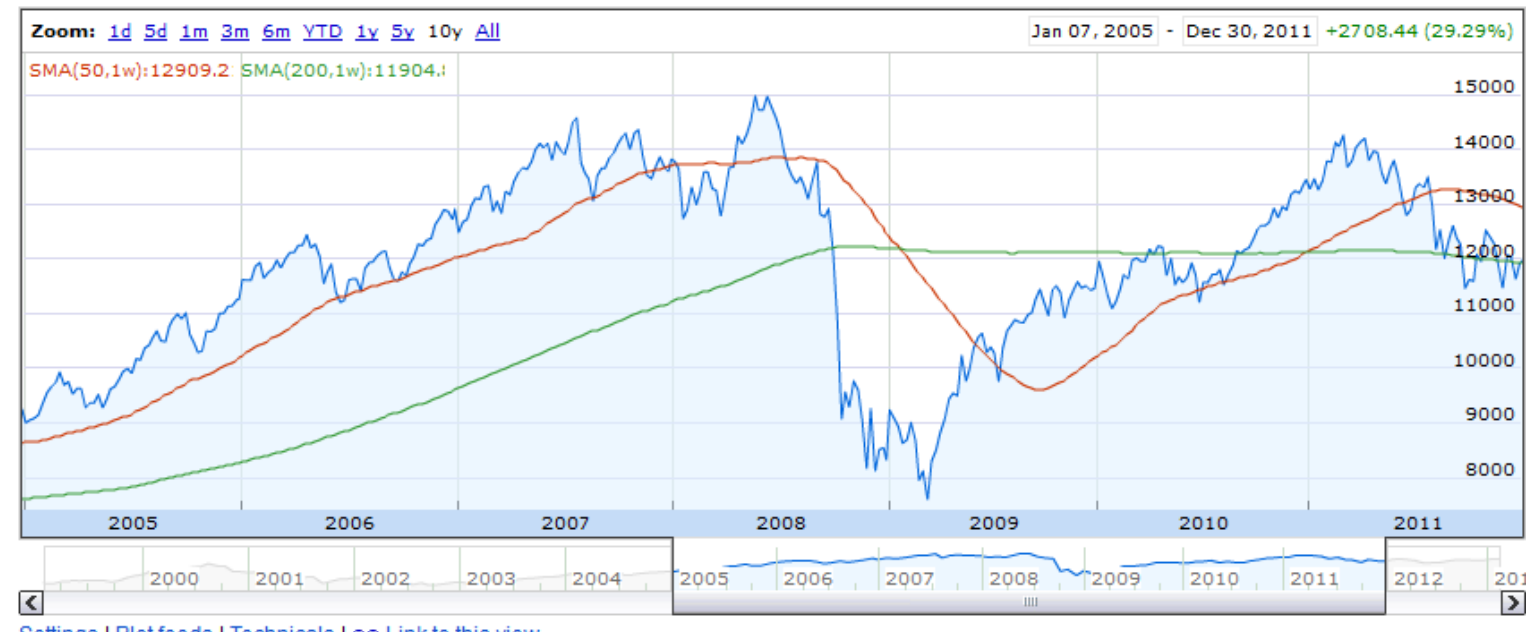

Settings | Plot feeds | Technicals | Link to this view

source: Google Finance

https://www.google.ca/finance?q=TSE\%3AOSPTX\&sq=TSX\&sp=1\&ei=3CUpUZj3Kcq3qAH0-gE\&hl=en 
Figure 4: NYSE Composite (Dow Jones) Index for the period January 1, 2005 - December 31, 2011

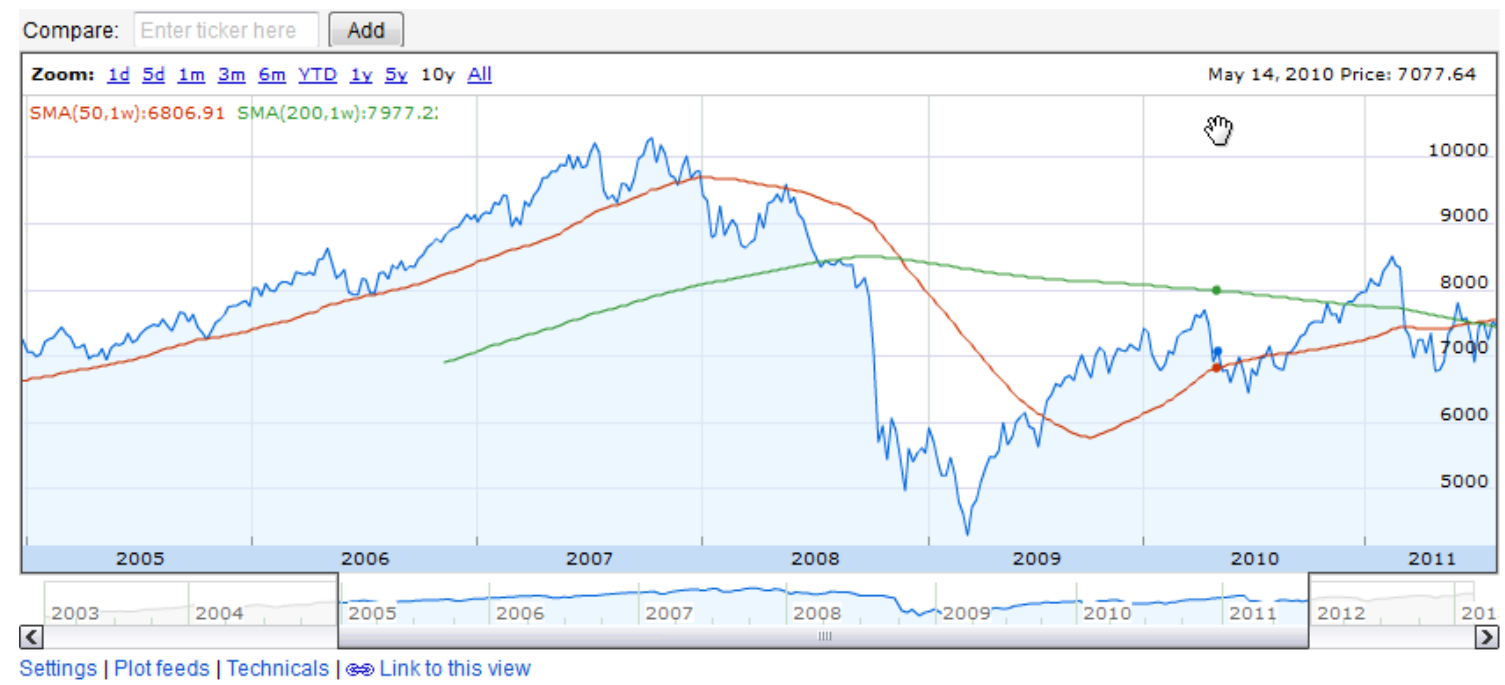

source: Google Finance

https://www.google.ca/finance?q=INDEXNYSEGIS\%3ANYA\&hl=en\&ei=fjEpUZi_EsW_rQGSWw

Although the crisis of 2007-2008, and the resulting economic slowdown was certainly not the first of its kind in history (Reinhart and Rogoff 2008), its severity was acute enough to earn it monikers such as "Financial Meltdown” and “The Great Recession” (Posner and Vermeule 2009; Cochrane 2011). The causes for the financial crisis continue to be studied extensively. A commonly cited reason for the crisis is a liquidity crunch (Brunnermeier and Pedersen 2009), triggered by the collapse of a major subprime lending fuelled real estate boom in early 2007 (Bordo 2008). The collapse of the housing market is in turn attributed to major changes in regulation, lax oversight, relaxation of lending standards, monetary policy that helped keep interest rates abnormally low over a prolonged period of time, thus creating incentives for excessive risk taking and engaging in fraudulent behaviour (Bordo 2008; Stiglitz 2009; Cecchetti 2008). Scholars of Behavioural Finance offer psychology based explanations, including overextrapolation and belief manipulation, as for why the crisis precipitated (Barberis 2011).

Whatever the reasons might have been for the crisis, it is undeniable that it created macroeconomic conditions that abnormally impacted financial markets, and financial instruments. 
Almost all of the items of OCI were directly, or indirectly, affected by the goings-on in the financial markets. For example, SEC and HEDGE values were directly impacted by changes in the values of financial instruments. As reported in table 6.6, the results were indeed different for the post-2006 period. However, even after controlling for the post-2006 period, HEDGE and SEC were found to be significantly positively associated with stock returns.

A consideration of the sample reveals a potential limitation of generalizability. The S\&P/TSX Composite Index, which is the leading index in Canada, is composed of 275 companies with a combined market capitalization of just over CAD 1.5 trillion. However, the index is dominated by financial sector (30 percent), energy (28 percent) and materials (17 percent) firms. While this may well be indicative of the composition of the Canadian economy, it does raise the likelihood that the results may be biased in favour of finding significance for comprehensive income and its components, all else being equal. This is because the components of OCI such as fair value changes in securities, foreign currency translations and cash flow hedges are more likely to apply to firms in sectors that dominate the Canadian index. The U.S. economy, in comparison, is more broad-based. The more specialized nature of the sample may reduce the generalizability of results.

\subsection{Conclusion and future research questions}

In this study I have made an earnest attempt to empirically investigate the decision usefulness of other comprehensive income, operationalized as association tests between OCI and components and stock price, stock returns, and analysts' earnings forecasts. The results suggest that at least some components of OCI are useful, thus lending support to the decision of accounting standard setters to require public companies to report unrealized gains and losses and other unrecognized amounts under the rubric of other comprehensive income.

The Joint Implementation Committee of the FASB and IASB adopted a comprehensive income approach to performance reporting. This study could be of interest to standard setters in providing additional empirical evidence in a non-U.S. setting of reporting comprehensive income and its components. Canada adopted the International Financial Reporting Standards (IFRS) for publicly traded companies for fiscal years starting 2011. The definition of OCI now includes two 
additional components to that under $\mathrm{OCI}_{130}$ : (i) Pension Adjustment, and (ii) Revaluation Surplus for assets accounted for under the Revaluation Model. The findings of this study provide a caveat against considering individual components of OCI as having similar value relevance. Some components, such as the unrealized gains and losses on available for sale securities appear to be more value relevant than others. Future empirical research could examine whether the broader definition of OCI under IFRS is decision useful. 
Appendix 1: List of companies

\begin{tabular}{|c|c|c|c|c|c|}
\hline GVKey & Company Name & $\begin{array}{c}\text { Ohlson } \\
\text { regressions }\end{array}$ & $\begin{array}{l}\text { Valuation } \\
\text { regressions }\end{array}$ & $\begin{array}{c}\text { Returns } \\
\text { regression }\end{array}$ & $\begin{array}{c}\text { Analysts' } \\
\text { Forecasts } \\
\text { regressions }\end{array}$ \\
\hline 105251 & Aastra Technologies Ltd & 4 & 5 & 4 & 3 \\
\hline 14999 & Ace Aviation Holdings Inc & 3 & 4 & 4 & 3 \\
\hline 166269 & Addax Petroleum Corp & 1 & 2 & 1 & 2 \\
\hline 27265 & Advantage Oil \&Gas Ltd & 3 & 4 & 0 & 0 \\
\hline 19987 & Aecon Group Inc & 4 & 5 & 5 & 3 \\
\hline 63562 & Aeterna Zentaris Inc & 2 & 3 & 3 & 2 \\
\hline 61955 & Agf Management Ltd -Cl B & 3 & 4 & 4 & 2 \\
\hline 1186 & Agnico Eagle Mines Ltd & 6 & 6 & 7 & 6 \\
\hline 28169 & Agrium Inc & 3 & 2 & 4 & 2 \\
\hline 164190 & Air Canada & 3 & 4 & 4 & 0 \\
\hline 156214 & Alacer Gold Corp & 3 & 4 & 4 & 0 \\
\hline 152848 & Alamos Gold Inc & 3 & 4 & 3 & 2 \\
\hline 1243 & Alcan Inc & 2 & 3 & 3 & 3 \\
\hline 115044 & Algonquin Power \& Util Corp & 3 & 4 & 4 & 0 \\
\hline 64655 & Alimentation Couche-Tard Inc & 2 & 3 & 3 & 2 \\
\hline 151040 & Allen-Vanguard Corp & 1 & 2 & 0 & 1 \\
\hline 152828 & Allied Pptys Real Estate Inv & 2 & 3 & 0 & 0 \\
\hline 122194 & Altagas Ltd & 3 & 4 & 4 & 0 \\
\hline 66060 & Angiotech Pharmaceuticals & 5 & 6 & 6 & 5 \\
\hline 160534 & Anvil Mining Ltd & 3 & 4 & 2 & 3 \\
\hline 105239 & Arc Resources Ltd & 3 & 4 & 4 & 2 \\
\hline 158765 & Artis Reit & 3 & 4 & 1 & 0 \\
\hline 15088 & Astral Media Inc -Cl A & 3 & 4 & 3 & 2 \\
\hline 1828 & Atco Ltd -Cl I & 3 & 4 & 4 & 3 \\
\hline 162346 & Atlantic Power Corp & 3 & 4 & 3 & 0 \\
\hline 29478 & Ats Automation Tooling Sys & 2 & 3 & 3 & 3 \\
\hline 19997 & Aurizon Mines Ltd & 3 & 4 & 1 & 2 \\
\hline 61781 & Axcan Pharma Inc & 2 & 3 & 3 & 3 \\
\hline 20499 & Bakbone Software Inc & 5 & 6 & 6 & 0 \\
\hline
\end{tabular}




\begin{tabular}{|c|c|c|c|c|c|}
\hline GVKey & Company Name & $\begin{array}{c}\text { Ohlson } \\
\text { regressions }\end{array}$ & $\begin{array}{l}\text { Valuation } \\
\text { regressions }\end{array}$ & $\begin{array}{c}\text { Returns } \\
\text { regression }\end{array}$ & $\begin{array}{c}\text { Analysts' } \\
\text { Forecasts } \\
\text { regressions }\end{array}$ \\
\hline 28724 & Ballard Power Systems Inc & 3 & 4 & 0 & 1 \\
\hline 15580 & Bank Of Montreal & 3 & 4 & 4 & 2 \\
\hline 15582 & Bank Of Nova Scotia & 3 & 4 & 4 & 2 \\
\hline 20440 & Bankers Petroleum Ltd & 3 & 4 & 0 & 0 \\
\hline 2055 & Barrick Gold Corp & 4 & 5 & 5 & 3 \\
\hline 29135 & Baytex Energy Corp & 3 & 4 & 2 & 2 \\
\hline 2137 & Bce Inc & 3 & 4 & 4 & 2 \\
\hline 175098 & Bell Aliant Inc & 3 & 4 & 0 & 1 \\
\hline 108391 & Bellatrix Exploration Ltd & 3 & 4 & 2 & 0 \\
\hline 137090 & Bellus Health Inc & 3 & 4 & 1 & 1 \\
\hline 105576 & Bennett Environmental Inc & 2 & 2 & 0 & 0 \\
\hline 142443 & Birchcliff Energy Ltd & 3 & 4 & 0 & 2 \\
\hline 107144 & Blackpearl Resources Inc & 3 & 4 & 0 & 0 \\
\hline 29552 & Boardwalk Real Estate Trust & 3 & 4 & 3 & 2 \\
\hline 64894 & Boliden Ab & 3 & 4 & 2 & 0 \\
\hline 14078 & Bombardier Inc -Cl B & 2 & 3 & 3 & 2 \\
\hline 26796 & Bonavista Energy Corp & 3 & 4 & 1 & 2 \\
\hline 13516 & Breakwater Resources Ltd & 3 & 4 & 3 & 0 \\
\hline 2369 & Brookfield Asset Management & 2 & 3 & 3 & 2 \\
\hline 15637 & Brookfield Office Properties & 3 & 3 & 0 & 2 \\
\hline 16423 & Brookfield Properties Corp & 3 & 5 & 5 & 0 \\
\hline 136684 & Brookfield Renewable Pwr Fd & 3 & 4 & 4 & 0 \\
\hline 135124 & Burntsand Inc & 0 & 1 & 1 & 0 \\
\hline 2526 & Cae Inc & 2 & 3 & 3 & 2 \\
\hline 12198 & Calfrac Well Services Ltd & 3 & 4 & 4 & 2 \\
\hline 105728 & Calloway Real Estate Invt Tr & 3 & 4 & 0 & 2 \\
\hline 24370 & Cameco Corp & 3 & 4 & 4 & 3 \\
\hline 64803 & Canadian Apt Pptys Reit & 3 & 4 & 4 & 2 \\
\hline 25948 & Canadian Hydro Developers & 1 & 2 & 2 & 2 \\
\hline 15581 & Canadian Imperial Bank & 3 & 4 & 4 & 2 \\
\hline
\end{tabular}




\begin{tabular}{|c|c|c|c|c|c|}
\hline GVKey & Company Name & $\begin{array}{c}\text { Ohlson } \\
\text { regressions }\end{array}$ & $\begin{array}{l}\text { Valuation } \\
\text { regressions }\end{array}$ & $\begin{array}{l}\text { Returns } \\
\text { regression }\end{array}$ & $\begin{array}{c}\text { Analysts' } \\
\text { Forecasts } \\
\text { regressions }\end{array}$ \\
\hline 2696 & Canadian National Railway Co & 5 & 5 & 6 & 4 \\
\hline 15055 & Canadian Natural Resources & 5 & 6 & 6 & 4 \\
\hline 105448 & Canadian Oil Sands Ltd & 3 & 4 & 3 & 2 \\
\hline 2698 & Canadian Pacific Railway Ltd & 3 & 4 & 4 & 2 \\
\hline 105755 & Canadian Real Estate Invt Tr & 3 & 4 & 4 & 2 \\
\hline 2703 & Canadian Tire Corp -Cl A & 3 & 4 & 4 & 2 \\
\hline 14433 & Canadian Utilities -Cl A & 4 & 5 & 5 & 4 \\
\hline 20285 & Canadian Western Bank & 3 & 4 & 4 & 2 \\
\hline 14301 & Canam Group Inc & 3 & 4 & 4 & 2 \\
\hline 14042 & Canfor Corp & 3 & 4 & 4 & 2 \\
\hline 175078 & Canfor Pulp Products Inc & 2 & 3 & 0 & 1 \\
\hline 24727 & Canwest Global Com -Nvtg & 2 & 3 & 2 & 0 \\
\hline 66729 & Capital Power Income Lp & 3 & 4 & 4 & 0 \\
\hline 126634 & Capstone Mining Corp & 3 & 4 & 3 & 0 \\
\hline 66374 & Cardiome Pharma Corp & 2 & 3 & 2 & 2 \\
\hline 14065 & Cascades Inc & 6 & 7 & 7 & 5 \\
\hline 2406 & Catalyst Paper Corp & 3 & 4 & 4 & 2 \\
\hline 14062 & $\mathrm{Ccl}$ Industries -Cl B & 3 & 4 & 4 & 2 \\
\hline 151563 & Ccs Income Trust & 0 & 1 & 1 & 1 \\
\hline 112158 & Celestica Inc & 3 & 4 & 4 & 2 \\
\hline 149417 & Celtic Exploration Ltd & 3 & 4 & 0 & 2 \\
\hline 183791 & Cenovus Energy Inc & 0 & 1 & 1 & 0 \\
\hline 160779 & Centerra Gold Inc & 3 & 4 & 0 & 2 \\
\hline 105847 & Certicom Corp & 0 & 1 & 1 & 1 \\
\hline 21864 & Cgi Group Inc -Cl A & 3 & 4 & 4 & 2 \\
\hline 157293 & Chartwell Senior Hsg Reit & 5 & 6 & 6 & 4 \\
\hline 20259 & Chc Helicopter Corp -Cl A & 0 & 1 & 1 & 1 \\
\hline 143297 & China Gold Intl Rsrcs Cp Ltd & 2 & 3 & 0 & 0 \\
\hline 165948 & Chorus Aviation Inc & 3 & 4 & 4 & 0 \\
\hline 30369 & Ci Financial Corp & 3 & 4 & 4 & 1 \\
\hline
\end{tabular}




\begin{tabular}{|c|c|c|c|c|c|}
\hline GVKey & Company Name & $\begin{array}{l}\text { Ohlson } \\
\text { regressions }\end{array}$ & $\begin{array}{l}\text { Valuation } \\
\text { regressions }\end{array}$ & $\begin{array}{l}\text { Returns } \\
\text { regression }\end{array}$ & $\begin{array}{c}\text { Analysts' } \\
\text { Forecasts } \\
\text { regressions }\end{array}$ \\
\hline 157476 & Cineplex Inc & 3 & 4 & 4 & 3 \\
\hline 20309 & Cinram Intl Income Fund & 3 & 4 & 4 & 2 \\
\hline 63997 & Cml Healthcare Inc & 3 & 4 & 3 & 2 \\
\hline 28555 & Cogeco Cable Inc & 3 & 4 & 4 & 2 \\
\hline 20315 & Cogeco Inc -Sub Vtg & 3 & 4 & 3 & 2 \\
\hline 14459 & Cognos Inc & 2 & 3 & 3 & 3 \\
\hline 179424 & Colossus Minerals Inc & 2 & 3 & 0 & 0 \\
\hline 64111 & Com Dev International Ltd & 3 & 4 & 4 & 2 \\
\hline 120654 & Cominar Real Estate Invt Tr & 3 & 4 & 0 & 2 \\
\hline 63673 & Compton Petroleum Corp & 3 & 4 & 0 & 2 \\
\hline 141368 & Conjuchem Biotech Inc & 2 & 3 & 3 & 0 \\
\hline 107107 & Connacher Oil \&Gas Ltd & 2 & 3 & 3 & 2 \\
\hline 145914 & Connors Bros Income Fund & 0 & 1 & 1 & 1 \\
\hline 140368 & Consldtd Thompson Iron Mines & 3 & 4 & 2 & 1 \\
\hline 3516 & Corby (H.) Distillery -Cl A & 3 & 4 & 1 & 0 \\
\hline 17080 & Corel Corp & 3 & 3 & 2 & 2 \\
\hline 123415 & Corus Entertainment Inc & 3 & 4 & 4 & 2 \\
\hline 20338 & Cott Corp Que & 6 & 7 & 6 & 5 \\
\hline 20339 & Counsel Corp & 2 & 3 & 3 & 0 \\
\hline 145812 & Crescent Point Energy Corp & 3 & 4 & 2 & 0 \\
\hline 156093 & Crew Energy Inc & 3 & 4 & 0 & 2 \\
\hline 133964 & Cryptologic Ltd & 2 & 3 & 0 & 3 \\
\hline 27598 & Crystallex International Cp & 2 & 3 & 0 & 2 \\
\hline 146543 & Davis \&Henderson Corp & 3 & 4 & 4 & 2 \\
\hline 106502 & Daylight Energy Ltd & 3 & 4 & 0 & 0 \\
\hline 64775 & Denison Mines Corp & 3 & 4 & 4 & 2 \\
\hline 66326 & Descartes Systems Group Inc & 6 & 7 & 6 & 6 \\
\hline 176598 & Detour Gold Corp & 3 & 4 & 0 & 2 \\
\hline 22049 & Dorel Industries Inc & 3 & 4 & 4 & 2 \\
\hline 24627 & Dundee Corp & 4 & 5 & 5 & 0 \\
\hline
\end{tabular}




\begin{tabular}{|c|c|c|c|c|c|}
\hline GVKey & Company Name & $\begin{array}{c}\text { Ohlson } \\
\text { regressions }\end{array}$ & $\begin{array}{c}\text { Valuation } \\
\text { regressions }\end{array}$ & $\begin{array}{c}\text { Returns } \\
\text { regression }\end{array}$ & $\begin{array}{c}\text { Analysts' } \\
\text { Forecasts } \\
\text { regressions }\end{array}$ \\
\hline 20007 & Dundee Precious Metls - $\mathrm{Cl}$ A & 3 & 4 & 4 & 0 \\
\hline 66376 & Dundee Real Estate Inv Trust & 4 & 7 & 7 & 1 \\
\hline 128559 & Dundeewealth Inc & 2 & 3 & 3 & 2 \\
\hline 27934 & Eacom Timber Corp & 1 & 1 & 0 & 0 \\
\hline 20529 & Eastern Platinum Ltd & 3 & 4 & 3 & 2 \\
\hline 16426 & E-L Financial Corp Ltd & 0 & 2 & 4 & 0 \\
\hline 26539 & Eldorado Gold Corp & 3 & 4 & 4 & 2 \\
\hline 25792 & Emera Inc & 5 & 6 & 6 & 4 \\
\hline 14312 & Empire Co Ltd -Cl A & 2 & 3 & 3 & 1 \\
\hline 6135 & Enbridge Inc & 4 & 5 & 5 & 3 \\
\hline 11781 & Encana Corp & 3 & 4 & 4 & 2 \\
\hline 151930 & Enercare Inc & 3 & 4 & 3 & 0 \\
\hline 28903 & Enerflex Systems Income Fund & 2 & 3 & 2 & 2 \\
\hline 20214 & Enerplus Corp & 4 & 5 & 5 & 3 \\
\hline 27013 & Ensign Energy Services Inc & 3 & 4 & 3 & 2 \\
\hline 160768 & Equinox Minerals Ltd & 3 & 4 & 4 & 2 \\
\hline 136807 & European Goldfields Ltd & 3 & 4 & 4 & 2 \\
\hline 137377 & Exfo Inc & 3 & 4 & 3 & 0 \\
\hline 13992 & Extendicare Reit & 3 & 4 & 4 & 0 \\
\hline 108815 & Fairborne Energy Ltd & 2 & 3 & 0 & 2 \\
\hline 16428 & Fairfax Financial Holdings & 1 & 3 & 5 & 1 \\
\hline 4669 & Finning International Inc & 3 & 4 & 4 & 3 \\
\hline 22970 & First Capital Realty Inc & 4 & 5 & 5 & 3 \\
\hline 108768 & First Majestic Silver Corp & 3 & 4 & 3 & 0 \\
\hline 106464 & First Quantum Minerals Ltd & 3 & 2 & 4 & 2 \\
\hline 28485 & Firstservice Corp -Svtg & 6 & 7 & 7 & 6 \\
\hline 146153 & Flint Energy Services Ltd & 5 & 6 & 6 & 4 \\
\hline 20465 & Fnx Mining Co Inc & 2 & 3 & 3 & 2 \\
\hline 144990 & Fording Canadian Coal Trust & 0 & 1 & 1 & 1 \\
\hline 14390 & Fortis Inc & 3 & 4 & 4 & 2 \\
\hline
\end{tabular}




\begin{tabular}{|c|c|c|c|c|c|}
\hline GVKey & Company Name & $\begin{array}{l}\text { Ohlson } \\
\text { regressions }\end{array}$ & $\begin{array}{l}\text { Valuation } \\
\text { regressions }\end{array}$ & $\begin{array}{l}\text { Returns } \\
\text { regression }\end{array}$ & $\begin{array}{c}\text { Analysts' } \\
\text { Forecasts } \\
\text { regressions }\end{array}$ \\
\hline 28803 & Forzani Group Ltd -Cl A & 2 & 3 & 3 & 3 \\
\hline 14070 & Fp Resources Ltd & 0 & 1 & 1 & 0 \\
\hline 178997 & Franco-Nevada Corp & 2 & 3 & 3 & 0 \\
\hline 160790 & Fraser Papers Inc & 1 & 2 & 2 & 2 \\
\hline 106528 & Freehold Royalties Ltd & 3 & 4 & 0 & 2 \\
\hline 141641 & Fronteer Gold Inc & 3 & 4 & 4 & 0 \\
\hline 64636 & Gabriel Resources Ltd & 3 & 4 & 0 & 2 \\
\hline 156556 & Galleon Energy Inc & 3 & 4 & 0 & 2 \\
\hline 123455 & Gammon Gold Inc & 3 & 4 & 1 & 2 \\
\hline 23496 & Gennum Corp & 3 & 4 & 4 & 2 \\
\hline 183231 & Genworth Mi Canada Inc & 0 & 2 & 1 & 0 \\
\hline 14049 & Gerdau Ameristeel Corp & 5 & 6 & 5 & 4 \\
\hline 111486 & Gildan Activewear Inc & 3 & 4 & 1 & 2 \\
\hline 157655 & Gmp Capital Inc & 3 & 4 & 4 & 0 \\
\hline 15037 & Goldcorp Inc & 3 & 4 & 4 & 2 \\
\hline 20488 & Golden Star Resources Ltd & 3 & 4 & 4 & 2 \\
\hline 160410 & Grande Cache Coal Corp & 2 & 3 & 0 & 0 \\
\hline 23504 & Great Basin Gold Ltd & 3 & 4 & 4 & 2 \\
\hline 106709 & Great Canadian Gaming Corp & 5 & 6 & 6 & 4 \\
\hline 16431 & Great-West Lifeco Inc & 3 & 4 & 4 & 2 \\
\hline 164169 & Groupe Aeroplan Inc & 3 & 4 & 3 & 1 \\
\hline 61356 & Gsi Group Inc & 0 & 1 & 1 & 1 \\
\hline 20475 & Guardian Cap Grp Ltd -Cl A & 2 & 3 & 3 & 2 \\
\hline 140372 & Guyana Goldfields Inc & 3 & 4 & 0 & 0 \\
\hline 64196 & H\&R Real Estate Invt Tr & 4 & 5 & 5 & 1 \\
\hline 15533 & Harry Winston Diamond Corp & 3 & 4 & 4 & 2 \\
\hline 151772 & Harvest Energy Trust & 1 & 2 & 2 & 2 \\
\hline 15050 & Heroux-Devtek Inc & 3 & 4 & 4 & 3 \\
\hline 20484 & High River Gold Mines Ltd & 2 & 3 & 2 & 2 \\
\hline 163690 & Highpine Oil \&Gas Ltd & 1 & 2 & 0 & 2 \\
\hline
\end{tabular}




\begin{tabular}{|c|c|c|c|c|c|}
\hline GVKey & Company Name & $\begin{array}{l}\text { Ohlson } \\
\text { regressions }\end{array}$ & $\begin{array}{l}\text { Valuation } \\
\text { regressions }\end{array}$ & $\begin{array}{l}\text { Returns } \\
\text { regression }\end{array}$ & $\begin{array}{c}\text { Analysts' } \\
\text { Forecasts } \\
\text { regressions }\end{array}$ \\
\hline 20487 & Home Capital Group Inc -Cl B & 2 & 3 & 3 & 2 \\
\hline 118227 & Hub International Ltd & 2 & 3 & 3 & 3 \\
\hline 107781 & Hudbay Minerals Inc & 3 & 5 & 4 & 4 \\
\hline 28711 & Hummingbird Ltd & 0 & 1 & 1 & 1 \\
\hline 13994 & Husky Energy Inc & 3 & 4 & 4 & 2 \\
\hline 140910 & Hydrogenics Corp & 3 & 4 & 4 & 0 \\
\hline 62337 & Iamgold Corp & 3 & 4 & 4 & 2 \\
\hline 14333 & Igm Financial Inc & 3 & 4 & 4 & 2 \\
\hline 30312 & Imax Corp & 6 & 7 & 7 & 5 \\
\hline 5903 & Imperial Oil Ltd & 3 & 4 & 4 & 2 \\
\hline 64091 & Indigo Books \&Music Inc & 2 & 3 & 1 & 2 \\
\hline 129472 & Industrial Alliance Ins \&Fin & 3 & 4 & 4 & 2 \\
\hline 14350 & Inmet Mining Corp & 3 & 4 & 4 & 2 \\
\hline 149700 & Innvest Real Estate Invt Tr & 2 & 3 & 0 & 2 \\
\hline 162491 & Intact Financial Corp & 3 & 4 & 4 & 0 \\
\hline 66319 & Inter Pipeline Fund & 3 & 4 & 4 & 2 \\
\hline 148130 & Interoil Corp & 1 & 2 & 2 & 2 \\
\hline 24943 & Intertape Polymer Group Inc & 2 & 3 & 2 & 1 \\
\hline 15038 & Intl Forest Products -Cl A & 4 & 5 & 5 & 3 \\
\hline 6180 & Ipsco Inc & 1 & 0 & 2 & 2 \\
\hline 117829 & Isotechnika Pharma Inc & 2 & 3 & 0 & 0 \\
\hline 30893 & Iteration Energy Ltd & 2 & 3 & 0 & 2 \\
\hline 64879 & Ivanhoe Energy Inc & 3 & 4 & 0 & 2 \\
\hline 63139 & Ivanhoe Mines Ltd & 5 & 6 & 6 & 4 \\
\hline 28852 & Jaguar Mining Inc & 3 & 4 & 0 & 1 \\
\hline 16474 & Jean Coutu Group & 2 & 3 & 3 & 2 \\
\hline 107938 & Jura Energy Corp & 1 & 2 & 0 & 0 \\
\hline 143403 & Just Energy Group Inc & 2 & 3 & 3 & 0 \\
\hline 154135 & Keyera Corp & 3 & 4 & 0 & 2 \\
\hline 61743 & Kingsway Financial Svcs Inc & 2 & 3 & 3 & 2 \\
\hline
\end{tabular}




\begin{tabular}{|c|c|c|c|c|c|}
\hline GVKey & Company Name & $\begin{array}{l}\text { Ohlson } \\
\text { regressions }\end{array}$ & $\begin{array}{l}\text { Valuation } \\
\text { regressions }\end{array}$ & $\begin{array}{l}\text { Returns } \\
\text { regression }\end{array}$ & $\begin{array}{c}\text { Analysts' } \\
\text { Forecasts } \\
\text { regressions }\end{array}$ \\
\hline 8644 & Kinross Gold Corp & 3 & 4 & 4 & 3 \\
\hline 105661 & Kirkland Lake Gold Inc & 2 & 3 & 0 & 0 \\
\hline 63128 & Labopharm Inc & 3 & 4 & 3 & 2 \\
\hline 64260 & Labrador Iron Ore Royalty Cp & 3 & 3 & 0 & 0 \\
\hline 6557 & Laidlaw International Inc & 1 & 2 & 2 & 2 \\
\hline 152012 & Lake Shore Gold Corp & 3 & 4 & 4 & 3 \\
\hline 16432 & Laurentian Bank Of Canada & 3 & 4 & 4 & 2 \\
\hline 65806 & Legacy Hotels Real Estate & 0 & 1 & 1 & 1 \\
\hline 174133 & Legacy Oil Plus Gas Inc & 1 & 2 & 0 & 0 \\
\hline 6672 & Leon's Furniture Ltd & 3 & 4 & 4 & 2 \\
\hline 20561 & Linamar Corp & 2 & 3 & 2 & 2 \\
\hline 28378 & Lions Gate Entertainment Cp & 1 & 2 & 2 & 2 \\
\hline 6771 & Loblaw Companies Ltd & 3 & 4 & 4 & 3 \\
\hline 25750 & Lorus Therapeutics Inc & 2 & 3 & 0 & 0 \\
\hline 108297 & Lundin Mining Corp & 3 & 4 & 4 & 2 \\
\hline 137609 & Macdonald Dettwiler \&Assoc & 3 & 4 & 4 & 2 \\
\hline 4763 & Magellan Aerospace Corp & 1 & 2 & 2 & 0 \\
\hline 6946 & Magna International Inc & 3 & 4 & 4 & 2 \\
\hline 31602 & Major Drilling Grp Intl Inc & 2 & 3 & 3 & 2 \\
\hline 65018 & Manitoba Telecom Svcs Inc & 3 & 4 & 0 & 2 \\
\hline 124042 & Manulife Financial Corp & 3 & 4 & 4 & 2 \\
\hline 2675 & Maple Leaf Foods Inc & 3 & 4 & 4 & 2 \\
\hline 65441 & Martinrea Intl Inc & 2 & 3 & 3 & 2 \\
\hline 20570 & Mdc Partners Inc & 6 & 7 & 6 & 5 \\
\hline 148455 & Mega Brands Inc & 1 & 3 & 3 & 1 \\
\hline 108250 & Mercator Minerals Ltd & 3 & 4 & 0 & 2 \\
\hline 13971 & Methanex Corp & 3 & 4 & 4 & 2 \\
\hline 21894 & Metro Inc - $\mathrm{Cl} \mathrm{A}$ & 3 & 4 & 4 & 2 \\
\hline 155458 & Mi Developments Inc & 3 & 4 & 4 & 2 \\
\hline 64779 & Minefinders Corp Ltd & 3 & 4 & 0 & 2 \\
\hline
\end{tabular}




\begin{tabular}{|c|c|c|c|c|c|}
\hline GVKey & Company Name & $\begin{array}{l}\text { Ohlson } \\
\text { regressions }\end{array}$ & $\begin{array}{l}\text { Valuation } \\
\text { regressions }\end{array}$ & $\begin{array}{l}\text { Returns } \\
\text { regression }\end{array}$ & $\begin{array}{c}\text { Analysts' } \\
\text { Forecasts } \\
\text { regressions }\end{array}$ \\
\hline 1096 & Morguard Corp & 4 & 5 & 5 & 2 \\
\hline 29407 & Mosaid Technologies Inc & 2 & 3 & 3 & 2 \\
\hline 30927 & Mullen Group Ltd & 3 & 4 & 0 & 0 \\
\hline 107505 & Nal Energy Corp & 3 & 4 & 1 & 2 \\
\hline 15620 & National Bank Canada & 3 & 4 & 4 & 2 \\
\hline 26511 & Neo Material Technologies & 3 & 4 & 3 & 0 \\
\hline 28080 & Nevsun Resources Ltd & 2 & 3 & 3 & 2 \\
\hline 106112 & New Gold Inc & 3 & 4 & 3 & 3 \\
\hline 20650 & Newalta Corp & 3 & 4 & 1 & 1 \\
\hline 2697 & Nexen Inc & 3 & 4 & 4 & 2 \\
\hline 107590 & Niko Resources Ltd & 2 & 0 & 3 & 2 \\
\hline 14313 & Norbord Inc & 4 & 5 & 5 & 0 \\
\hline 14102 & Nordion Inc & 3 & 4 & 4 & 0 \\
\hline 23170 & Norsat Intl Inc & 2 & 3 & 2 & 1 \\
\hline 7980 & Nortel Networks Corp & 3 & 4 & 4 & 3 \\
\hline 6930 & North American Palladium & 3 & 4 & 0 & 2 \\
\hline 23994 & North West Co Inc & 2 & 3 & 3 & 3 \\
\hline 154058 & Northbridge Financial Corp & 0 & 1 & 1 & 1 \\
\hline 119394 & Northcore Technologies Inc & 2 & 2 & 0 & 0 \\
\hline 107637 & Northern Dynasty Mineral Ltd & 2 & 3 & 3 & 0 \\
\hline 7984 & Northgate Minerals Corp & 3 & 4 & 4 & 2 \\
\hline 64625 & Northland Power Inc & 3 & 4 & 4 & 3 \\
\hline 8009 & Nova Chemicals Corp & 1 & 2 & 2 & 2 \\
\hline 20600 & Novagold Resources Ltd & 3 & 4 & 4 & 2 \\
\hline 162701 & Novelis Inc & 1 & 2 & 1 & 1 \\
\hline 154774 & Nuvista Energy Ltd & 3 & 4 & 2 & 2 \\
\hline 106179 & Nuvo Research Inc & 3 & 4 & 0 & 1 \\
\hline 260651 & Oceanagold Corp & 3 & 4 & 3 & 0 \\
\hline 107685 & Oilexco Inc & 1 & 2 & 2 & 2 \\
\hline 20245 & Oncothyreon Inc & 1 & 2 & 1 & 1 \\
\hline
\end{tabular}




\begin{tabular}{|c|c|c|c|c|c|}
\hline GVKey & Company Name & $\begin{array}{l}\text { Ohlson } \\
\text { regressions }\end{array}$ & $\begin{array}{l}\text { Valuation } \\
\text { regressions }\end{array}$ & $\begin{array}{l}\text { Returns } \\
\text { regression }\end{array}$ & $\begin{array}{c}\text { Analysts' } \\
\text { Forecasts } \\
\text { regressions }\end{array}$ \\
\hline 14326 & Onex Corp & 3 & 4 & 4 & 2 \\
\hline 61870 & Open Text Corp & 5 & 6 & 6 & 4 \\
\hline 13453 & Oppenheimer Holdings Inc & 3 & 4 & 4 & 0 \\
\hline 160191 & Opti Canada Inc & 3 & 4 & 0 & 2 \\
\hline 107710 & Osisko Mining Corp & 3 & 4 & 1 & 1 \\
\hline 105222 & Pacific Rubiales Energy Corp & 3 & 4 & 1 & 1 \\
\hline 20670 & Pan American Silver Corp & 3 & 4 & 4 & 2 \\
\hline 20676 & Paramount Resources Ltd & 3 & 4 & 4 & 2 \\
\hline 66318 & Pason Systems Inc & 3 & 4 & 4 & 2 \\
\hline 19985 & Patheon Inc & 3 & 4 & 0 & 2 \\
\hline 130618 & Pembina Pipeline Corp & 3 & 4 & 4 & 2 \\
\hline 20683 & Pengrowth Energy Corp & 3 & 4 & 0 & 2 \\
\hline 20684 & Penn West Petroleum Ltd & 3 & 4 & 0 & 3 \\
\hline 152692 & Perpetual Energy Inc & 3 & 4 & 0 & 0 \\
\hline 29769 & Petrobank Energy Res Ltd & 3 & 4 & 3 & 2 \\
\hline 15150 & Petro-Canada & 1 & 2 & 2 & 0 \\
\hline 278317 & Petrominerales Ltd & 2 & 3 & 0 & 0 \\
\hline 106156 & Peyto Exploration \&Develpmt & 3 & 4 & 4 & 2 \\
\hline 121154 & Pinetree Capital Ltd & 1 & 2 & 0 & 0 \\
\hline 8626 & Placer Dome Inc & 0 & 1 & 1 & 1 \\
\hline 16582 & Potash Corp Sask Inc & 3 & 1 & 4 & 2 \\
\hline 8702 & Power Corp Canada & 3 & 4 & 3 & 2 \\
\hline 15607 & Power Financial Corp & 3 & 4 & 4 & 2 \\
\hline 20695 & Precision Drilling Corp & 3 & 4 & 3 & 0 \\
\hline 155099 & Primaris Retail Reit & 3 & 4 & 4 & 2 \\
\hline 160820 & Progress Energy Resources Cp & 3 & 4 & 1 & 0 \\
\hline 107928 & Progress Energy Trust & 0 & 1 & 1 & 1 \\
\hline 148394 & Progressive Waste Solutions & 3 & 4 & 4 & 0 \\
\hline 106519 & Provident Energy Ltd & 4 & 5 & 4 & 3 \\
\hline 15803 & Qlt Inc & 5 & 6 & 5 & 4 \\
\hline
\end{tabular}




\begin{tabular}{|c|c|c|c|c|c|}
\hline GVKey & Company Name & $\begin{array}{l}\text { Ohlson } \\
\text { regressions }\end{array}$ & $\begin{array}{l}\text { Valuation } \\
\text { regressions }\end{array}$ & $\begin{array}{l}\text { Returns } \\
\text { regression }\end{array}$ & $\begin{array}{c}\text { Analysts' } \\
\text { Forecasts } \\
\text { regressions }\end{array}$ \\
\hline 266305 & Quadra Fnx Mining Ltd & 3 & 4 & 4 & 0 \\
\hline 8870 & Quebecor Inc -Cl B & 3 & 4 & 4 & 1 \\
\hline 155224 & Questerre Energy Corp & 2 & 3 & 0 & 1 \\
\hline 105857 & Red Back Mining Inc & 2 & 3 & 3 & 2 \\
\hline 9034 & Reitmans (Canada) -Cl A & 3 & 4 & 3 & 3 \\
\hline 65986 & Research In Motion Ltd & 5 & 0 & 6 & 5 \\
\hline 28661 & Richelieu Hardware Ltd & 3 & 4 & 4 & 2 \\
\hline 108071 & Riocan Reit & 3 & 4 & 2 & 2 \\
\hline 65605 & Ritchie Bros Auctioneers Inc & 5 & 4 & 6 & 4 \\
\hline 9215 & Rogers Communications -Cl B & 3 & 4 & 4 & 3 \\
\hline 151118 & Rona Inc & 3 & 4 & 0 & 2 \\
\hline 15633 & Royal Bank Of Canada & 3 & 4 & 4 & 2 \\
\hline 65808 & Rubicon Minerals Corp & 2 & 3 & 3 & 1 \\
\hline 4599 & Russel Metals Inc & 2 & 3 & 2 & 1 \\
\hline 65613 & Saputo Inc & 2 & 3 & 3 & 2 \\
\hline 136266 & Savanna Energy Svcs Corp & 3 & 4 & 3 & 2 \\
\hline 20743 & Sceptre Investment Counsel & 2 & 3 & 3 & 2 \\
\hline 11787 & Sears Canada Inc & 3 & 4 & 2 & 2 \\
\hline 28415 & Semafo Inc & 3 & 4 & 2 & 2 \\
\hline 14353 & Shaw Communications Inc-Cl B & 3 & 4 & 3 & 2 \\
\hline 9647 & Shawcor Ltd -Cl A & 3 & 4 & 4 & 2 \\
\hline 63075 & Sherritt International Corp & 3 & 4 & 4 & 2 \\
\hline 146139 & Shoppers Drug Mart Corp & 3 & 4 & 4 & 2 \\
\hline 108233 & Shore Gold Inc & 2 & 3 & 0 & 2 \\
\hline 120334 & Sierra Wireless Inc & 5 & 6 & 5 & 4 \\
\hline 26768 & Silver Standard Res Inc & 3 & 4 & 4 & 2 \\
\hline 105861 & Silver Wheaton Corp & 3 & 4 & 4 & 2 \\
\hline 108326 & Silvercorp Metals Inc & 2 & 3 & 2 & 1 \\
\hline 62359 & Sino-Forest Corp & 3 & 4 & 4 & 2 \\
\hline 14352 & Snc-Lavalin Group Inc & 4 & 5 & 5 & 3 \\
\hline
\end{tabular}




\begin{tabular}{|c|c|c|c|c|c|}
\hline GVKey & Company Name & $\begin{array}{l}\text { Ohlson } \\
\text { regressions }\end{array}$ & $\begin{array}{l}\text { Valuation } \\
\text { regressions }\end{array}$ & $\begin{array}{l}\text { Returns } \\
\text { regression }\end{array}$ & $\begin{array}{c}\text { Analysts' } \\
\text { Forecasts } \\
\text { regressions }\end{array}$ \\
\hline 157793 & Southgobi Resources Ltd & 2 & 3 & 1 & 0 \\
\hline 28649 & Southwestern Resources Corp & 0 & 1 & 1 & 1 \\
\hline 9373 & St Lawrence Cement Grp -Cl A & 0 & 1 & 1 & 2 \\
\hline 29985 & Stantec Inc & 3 & 4 & 4 & 2 \\
\hline 133289 & Sun Life Financial Inc & 3 & 4 & 4 & 2 \\
\hline 15070 & Suncor Energy Inc & 3 & 3 & 4 & 0 \\
\hline 65614 & Superior Plus Corp & 3 & 4 & 4 & 0 \\
\hline 31616 & Sxc Health Solutions Corp & 3 & 4 & 2 & 2 \\
\hline 14316 & Talisman Energy Inc & 3 & 4 & 4 & 2 \\
\hline 26914 & Tanzanian Royalty Explor Cp & 3 & 4 & 0 & 0 \\
\hline 25092 & Taseko Mines Ltd & 3 & 4 & 3 & 2 \\
\hline 10385 & Teck Resources Ltd & 3 & 4 & 3 & 3 \\
\hline 62475 & Tekmira Pharmaceuticals Corp & 2 & 3 & 0 & 2 \\
\hline 121933 & Teknion Corp & 0 & 1 & 1 & 1 \\
\hline 2408 & Telus Corp & 3 & 4 & 4 & 0 \\
\hline 14372 & Tembec Inc & 3 & 4 & 0 & 1 \\
\hline 174838 & Teranet Income Fund & 0 & 1 & 1 & 0 \\
\hline 20747 & Tesco Corp & 1 & 2 & 2 & 2 \\
\hline 29476 & Theratechnologies Inc & 3 & 4 & 4 & 2 \\
\hline 122266 & Thompson Creek Metals Co Inc & 3 & 4 & 3 & 1 \\
\hline 15704 & Thomson-Reuters Corp & 4 & 5 & 5 & 3 \\
\hline 166366 & Tim Hortons Inc & 5 & 6 & 4 & 3 \\
\hline 136705 & Timberwest Forest Corp & 3 & 4 & 0 & 0 \\
\hline 20809 & Timminco Ltd & 2 & 3 & 2 & 3 \\
\hline 62465 & Tlc Vision Corp & 0 & 1 & 1 & 1 \\
\hline 151282 & Tmx Group Inc & 3 & 4 & 3 & 1 \\
\hline 15020 & Toromont Industries Ltd & 3 & 4 & 4 & 2 \\
\hline 15706 & Toronto Dominion Bank & 4 & 5 & 5 & 3 \\
\hline 13997 & Torstar Corp -Cl B & 3 & 4 & 4 & 2 \\
\hline 14391 & Transalta Corp & 3 & 4 & 4 & 2 \\
\hline
\end{tabular}




\begin{tabular}{|c|c|c|c|c|c|}
\hline GVKey & Company Name & $\begin{array}{l}\text { Ohlson } \\
\text { regressions }\end{array}$ & $\begin{array}{l}\text { Valuation } \\
\text { regressions }\end{array}$ & $\begin{array}{l}\text { Returns } \\
\text { regression }\end{array}$ & $\begin{array}{c}\text { Analysts' } \\
\text { Forecasts } \\
\text { regressions }\end{array}$ \\
\hline 28059 & Transat A T Inc & 3 & 4 & 4 & 0 \\
\hline 10671 & Transcanada Corp & 3 & 4 & 4 & 2 \\
\hline 15083 & Transcontinental Inc -Cl A & 3 & 4 & 4 & 2 \\
\hline 150764 & Transforce Inc & 3 & 4 & 0 & 1 \\
\hline 14010 & Transglobe Energy Corp & 3 & 4 & 2 & 0 \\
\hline 64107 & Trican Well Service Ltd & 3 & 4 & 4 & 2 \\
\hline 163697 & Trilogy Energy Corp & 3 & 4 & 0 & 0 \\
\hline 140674 & Trinidad Drilling Ltd & 4 & 5 & 5 & 1 \\
\hline 165864 & Tristar Oil \&Gas Ltd & 1 & 2 & 2 & 1 \\
\hline 15123 & Trizec Properties Inc & 1 & 2 & 2 & 2 \\
\hline 108611 & Turbo Power Systems Inc & 2 & 3 & 0 & 0 \\
\hline 13970 & Tva Group Inc -Cl B & 2 & 3 & 2 & 2 \\
\hline 149563 & Uex Corp & 2 & 3 & 0 & 1 \\
\hline 19696 & Uni-Select Inc & 4 & 5 & 0 & 0 \\
\hline 65324 & Uranium One Inc & 3 & 4 & 3 & 2 \\
\hline 20838 & Uts Energy Corp & 2 & 3 & 0 & 2 \\
\hline 29955 & Valeant Pharmaceuticals Intl & 6 & 7 & 6 & 0 \\
\hline 22079 & Van Houtte Inc & 0 & 1 & 1 & 1 \\
\hline 132558 & Vector Aerospace Corp & 2 & 3 & 3 & 2 \\
\hline 181671 & Ventana Gold Corp & 1 & 2 & 0 & 0 \\
\hline 66277 & Veresen Inc & 3 & 4 & 4 & 0 \\
\hline 30075 & Vermilion Energy Inc & 3 & 4 & 0 & 2 \\
\hline 62556 & Viterra Inc & 3 & 4 & 3 & 1 \\
\hline 30863 & Wescast Industries - $\mathrm{Cl} \mathrm{A}$ & 1 & 2 & 1 & 1 \\
\hline 14330 & West Fraser Timber Co & 3 & 4 & 4 & 2 \\
\hline 65261 & Westaim Corp & 3 & 4 & 3 & 2 \\
\hline 118837 & Western Coal Corp & 2 & 3 & 1 & 0 \\
\hline 122017 & Westjet Airlines Ltd & 3 & 4 & 3 & 2 \\
\hline 11443 & Weston (George) Ltd & 3 & 4 & 4 & 2 \\
\hline 108831 & Westport Innovations Inc & 2 & 3 & 3 & 0 \\
\hline
\end{tabular}




\begin{tabular}{|c|c|c|c|c|c|}
\hline GVKey & Company Name & $\begin{array}{c}\text { Ohlson } \\
\text { regressions }\end{array}$ & $\begin{array}{c}\text { Valuation } \\
\text { regressions }\end{array}$ & $\begin{array}{c}\text { Returns } \\
\text { regression }\end{array}$ & $\begin{array}{c}\text { Analysts' } \\
\text { Forecasts } \\
\text { regressions }\end{array}$ \\
\hline 108718 & Vasogen Inc & 0 & 1 & 0 & 1 \\
\hline 115628 & Husky Injection Molding Sys & 0 & 1 & 0 & 1 \\
\hline 11790 & Rothmans Inc & 0 & 1 & 0 & 1 \\
\hline 117941 & Tundra Semiconductor Corp & 0 & 1 & 0 & 1 \\
\hline 140937 & Cryocath Technologies Inc & 0 & 1 & 0 & 1 \\
\hline 149033 & Aurelian Resources Inc & 0 & 1 & 0 & 1 \\
\hline 158589 & Duvernay Oil Corp & 0 & 1 & 0 & 1 \\
\hline 165575 & Synenco Energy Inc & 0 & 1 & 0 & 1 \\
\hline 20434 & First Calgary Petroleums Ltd & 0 & 1 & 0 & 1 \\
\hline 29464 & Nventa Biopharmaceuticals & 0 & 1 & 0 & 1 \\
\hline 66401 & Westshore Terms Investmnt Cp & 3 & 4 & 0 & 2 \\
\hline 20391 & Gold Eagle Mines Ltd & 0 & 1 & 0 & 0 \\
\hline 26233 & Biowest Therapeutics Inc & 0 & 1 & 0 & 0 \\
\hline 183667 & Petrobakken Energy Ltd & 0 & 1 & 0 & 0 \\
\hline 183683 & Dollarama Inc & 0 & 1 & 0 & 0 \\
\hline 128121 & Wi-Lan Inc & 3 & 4 & 0 & 2 \\
\hline 20860 & Winpak Ltd & 3 & 4 & 4 & 2 \\
\hline 25291 & World Color Press Inc & 0 & 1 & 1 & 0 \\
\hline 31519 & Yamana Gold Inc & 3 & 4 & 4 & 2 \\
\hline 155313 & Yellow Media Inc & 3 & 4 & 4 & 2 \\
\hline 7469 & Zarlink Semiconductor Inc & 5 & 6 & 6 & 5 \\
\hline 26264 & ZI Corp & 4 & 5 & 5 & 3 \\
\hline & & 1074 & 1464 & 1097 & 675 \\
\hline
\end{tabular}




\section{References}

Aboody, D., M. E. Barth, and R. Kasznik. 1999. Revaluations of fixed assets and future firm performance: Evidence from the UK. Journal of Accounting and Economics 26 (13):149-178.

Accounting Standards Board of Canada. 2004. Accounting Standards in Canada: Future Directions.

—. 2006. Accounting Standards in Canada: New Directions.

Ahmed, A. S., S. M. K. Nainar, and J. Zhou. 2005. Do Analysts' Earnings Forecasts Fully Reflect the Information in Accruals? Canadian Journal of Administrative Sciences 22 (4):329.

Arnold, P. J. 2005. Disciplining domestic regulation: the World Trade Organization and the market for professional services. Accounting, Organizations and Society 30 (4):299-330.

Ashton, R. H. 1976. Cognitive Changes Induced by Accounting Changes: Experimental Evidence on the Functional Fixation Hypothesis. Journal of Accounting Research 14:117.

Bae, K., H. Tan, and M. Welker. 2008. International GAAP Differences: The Impact on Foreign Analysts. The Accounting Review 83 (3):593.

Ball, R. 2009. The global financial crisis and the efficient market hypothesis: What have we learned? Journal of Applied Corporate Finance 21 (4):8-16.

Ball, R., and P. Brown. 1968. An empirical evaluation of accounting income numbers. Journal of Accounting Research:159-178.

Bamber, L., J. Jiang, K. Petroni, and I. Wang. 2010. Comprehensive Income: Who's Afraid of Performance Reporting? The Accounting Review 85 (1):97.

Barberis, N. 2011. Psychology and the Financial Crisis of 2007-2008. Available at SSRN 1742463.

Barth, M. E., W. H. Beaver, J. R. M. Hand, and W. R. Landsman. 1999. Accruals, Cash Flows, and Equity Values. Review of Accounting Studies 4 (3-4):205. 
Barth, M. E., W. H. Beaver, and W. R. Landsman. 1992. The market valuation implications of net periodic pension cost components. Journal of Accounting and Economics 15 (1):2762.

- 2001a. The relevance of the value relevance literature for financial accounting standard setting: another view. Journal of Accounting and Economics 31 (1-3):77-104.

Barth, M. E., D. P. Cram, and K. K. Nelson. 2001b. Accruals and the prediction of future cash flows. The Accounting Review 76 (1):27-58.

Barth, M. E., and A. P. Hutton. 2004. Analyst Earnings Forecast Revisions and the Pricing of Accruals. Review of Accounting Studies 9 (1):59.

Beaver, W. H. 1968. The Information Content of Annual Earnings Announcements. Journal of Accounting Research 6:67-92.

Beaver, W. H., M. L. McAnally, and C. H. Stinson. 1997. The information content of earnings and prices: A simultaneous equations approach. Journal of Accounting and Economics 23 (1):53-81.

Behn, B., J. Choi, and T. Kang. 2008. Audit Quality and Properties of Analyst Earnings Forecasts. The Accounting Review 83 (2):327.

Beresford, D. R., L. T. Johnson, and C. L. Reither. 1996. Is a second income statement needed? Journal of Accountancy 181 (4):69.

Bernard, M. 2008. The impact of internationalization and regulation on the relationship between education quality and the accuracy of stock analysts' earnings forecasts. 3328507, Nova Southeastern University, United States -- Florida.

Beyer, A., and I. Guttman. 2011. The Effect of Trading Volume on Analysts' Forecast Bias. Accounting Review 86 (2):451-481.

Bhamornsiri, S., and C. Wiggins. 2001. Comprehensive income disclosures. The CPA Journal 71 (10):54.

Bhat, G., O.-K. Hope, and T. Kang. 2006. Does corporate governance transparency affect the accuracy of analyst forecasts? Accounting and Finance 46 (5):715. 
Biddle, G. C., and J. H. Choi. 2006. Is comprehensive income useful? Journal of Contemporary Accounting \& Economics 2 (1):1-32.

Bisgay, L. 1995. Comprehensive income. Management Accounting 77 (6):57.

Blanchette, M., and A. Desfleurs. 2011. Critical Perspectives on the Implementation of IFRS in Canada. Journal of Global Business Administration 3 (1).

Block, S. B. 1999. A study of financial analysts: practice and theory. Financial Analysts Journal:86-95.

Bloomfield, R. J., M. W. Nelson, and S. D. Smith. 2006. Feedback loops, fair value accounting and correlated investments. Review of Accounting Studies 11 (2-3):377.

Bodie, Z., A. Kane, A. J. Marcus, S. Perrakis, and P. J. Ryan. 2003. Investments. 4th Canadian Edition ed. Toronto: McGraw-Hill Ryerson.

Bonner, S. E., B. R. Walther, and S. M. Young. 2003. Sophistication-related differences in investors' models of the relative accuracy of analysts' forecast revisions. The Accounting Review 78 (3):679-706.

Bordo, M. D. 2008. An historical perspective on the crisis of 2007-2008: National Bureau of Economic Research.

Botosan, C. A., and M. S. Harris. 2000. Motivations for a change in disclosure frequency and its consequences: An examination of voluntary quarterly segment disclosures. Journal of Accounting Research 38 (2):329-353.

Bouwman, M., P. Frishkoff, and P. A. Frishkoff. 1995. The relevance of GAAP-based information: A case study exploring some uses and limitations. Accounting Horizons 9:22-47.

Bradshaw, M. T. 2000. The articulation of sell-side analysts' earnings forecasts, common stock valuations and investment recommendations. 9990851, University of Michigan, United States -- Michigan.

Bradshaw, M. T. 2004. How do analysts use their earnings forecasts in generating stock recommendations? Accounting Review:25-50. 
Bradshaw, M. T. 2009. Analyst Information Processing, Financial Regulation, and Academic Research. Accounting Review 84 (4):1073-1083.

Brauchle, G. J., and C. L. Reither. 1997. SFAS No. 130: Reporting comprehensive income. The CPA Journal 67 (10):42.

Bricker, R., G. Previts, T. Robinson, and S. Young. 1995. Financial analyst assessment of company earnings quality. Journal of Accounting, Auditing \& Finance 10 (3):541-554.

Brief, R. P., and K. V. Peasnell. 1996. Clean surplus: A link between accounting and finance: Routledge.

Brimble, M., and A. Hodgson. 2004. The Value Relevance of Comprehensive Income and Components for Industrial Firms: Working Paper, Griffith University/Amsterdam Business School (Universiteit of Amsterdam).

Brimble, M., and A. Hodgson. 2007. Assessing the risk relevance of accounting variables in diverse economic conditions. Managerial Finance 33 (8):553.

Brown, L. D. 1993. Earnings forecasting research: its implications for capital markets research. International Journal of Forecasting 9 (3):295-320.

Brunnermeier, M. K., and L. H. Pedersen. 2009. Market liquidity and funding liquidity. Review of Financial studies 22 (6):2201-2238.

Bryan, D. M., and S. L. Tiras. 2007. The Influence of Forecast Dispersion on the Incremental Explanatory Power of Earnings, Book Value, and Analyst Forecasts on Market Prices. The Accounting Review 82 (3):651.

Bujaki, M. L., and A. J. Richardson. 1997. A citation trail review of the uses of firm size in accounting research. Journal of Accounting Literature 16:1-27.

Cahan, S. F., S. M. Courtenay, P. L. GroneWoller, and D. R. Upton. 2000. Value relevance of mandated comprehensive income disclosures. Journal of Business Finance \& Accounting 27 (9/10):1273.

Canadian Bankers Association. 1997. Interim Submission to the Task Force on the Future of the Canadian Financial Services Sector: Canadian Bankers Association. 
Cecchetti, S. G. 2008. Monetary policy and the financial crisis of 2007-2008. CEPR Policy Insight (21).

Centre for Financial Market Integrity. 2007. A Comprehensive Business Reporting Model: Financial Reporting for Investors. Charlottesville, VA: CFA Institute.

Chambers, D., T. J. Linsmeier, C. Shakespeare, and T. Sougiannis. 2007. An evaluation of SFAS No. 130 comprehensive income disclosures. Review of Accounting Studies 12 (4):557.

Chen, C.-Y., and P. F. Chen. 2009. NASD Rule 2711 and Changes in Analysts' Independence in Making Stock Recommendations. Accounting Review 84 (4):1041-1071.

Chen, C., Y. Ding, and C. Kim. 2010. High-level politically connected firms, corruption, and analyst forecast accuracy around the world. Journal of International Business Studies 41 (9):1505.

Chen, S. 1981. Beta nonstationarity, portfolio residual risk and diversification. Journal of Financial and Quantitative Analysis 16 (1):95-111.

Cheng, C. S. A., J. K. Cheung, and V. Gopalakrishnan. 1993. On the usefulness of operating income, net income and comprehensive income in explaining security returns. Accounting and Business Research 23 (91):195.

Cheng, Q., and T. D. Warfield. 2005. Equity incentives and earnings management. The Accounting Review 80 (2):441-476.

Choi, J. H., S. Das, and Y. Zang. 2007. Comprehensive Income, Future Earnings and Market Mispricing. Seoul: Seoul National University.

Choi, J. H., and Y. Zang. 2006. Implications of Comprehensive Income Disclosure For Future Earning and Analysts' Forecasts. Seoul Journal of Business 12 (2).

Chopra, V. K. 1998. Why so much error in analysts' earnings forecasts? Financial Analysts Journal 54 (6):35.

Chua, W. F., and S. L. Taylor. 2008. The rise and rise of IFRS: An examination of IFRS diffusion. Journal of Accounting and Public Policy 27 (6):462-473. 
CIA. 2008. The World Factbook: Canada. The Central Intelligence Agency, USA 2008 [cited April 7 2008]. Available from https://www.cia.gov/library/publications/the-worldfactbook/geos/ca.html\#Econ.

CICA. 2005a. Comprehensive Income and Equity - Background Information and Basis for Conclusions. In CICA Standards and Guidance Collection: Knotia Canada Limited Partnership.

—. 2005b. Section 1530 Comprehensive Income. In CICA Standards and Guidance Collection: Knotia Canada Limited Partnership.

Clarkson, P. M., and R. Thompson. 1990. Empirical estimates of beta when investors face estimation risk. The Journal of Finance 45 (2):431-453.

Clement, M. B. 1999. Analyst forecast accuracy: Do ability, resources, and portfolio complexity matter? Journal of Accounting and Economics 27 (3):285-303.

Cochrane, J. H. 2011. Understanding policy in the great recession: Some unpleasant fiscal arithmetic. European Economic Review 55 (1):2-30.

Collins, D. W., E. L. Maydew, and I. S. Weiss. 1997. Changes in the value-relevance of earnings and book values over the past forty years. Journal of Accounting and Economics 24 (1):39-67.

Cope, A. T., L. T. Johnson, and C. L. Reither. 1996. The call for reporting comprehensive income. Financial Analysts Journal 52 (2):7.

Cortese, C. L., and H. J. Irvine. 2010. Investigating iternational accounting standard setting: the black box of IFRS 6. Research in Accounting Regulation 22 (2):87-95.

Cready, W., T. J. Lopez, and C. A. Sisneros. 2010. The persistence and market valuation of recurring nonrecurring items. The Accounting Review 85:1577.

Das, S., C. B. Levine, and K. Sivaramakrishnan. 1998. Earnings predictability and bias in analysts' earnings forecasts. Accounting Review:277-294.

Daske, H., L. Hail, C. Leuz, and R. Verdi. 2008. Mandatory IFRS Reporting around the World: Early Evidence on the Economic Consequences. Journal of Accounting Research 46 (5):1085. 
Davis-Friday, P. Y., and E. A. Gordon. 2005. Relative Valuation Roles of Equity Book Value, Net Income, and Cash Flows during a Macroeconomic Shock: The Case of Mexico and the 1994 Currency Crisis. Journal of International Accounting Research 4 (1):1.

Dechow, P. M., A. P. Hutton, and R. G. Sloan. 1999. An empirical assessment of the residual income valuation model. Journal of Accounting \& Economics 26 (1-3):1-34.

Dechow, P. M., S. Kothari, and R. L Watts. 1998. The relation between earnings and cash flows. Journal of Accounting and Economics 25 (2):133-168.

Dechow, P. M., and R. G. Sloan. 1991. Executive incentives and the horizon problem: An empirical investigation. Journal of Accounting and Economics 14 (1):51-89.

Dee, C. C. 1999. Comprehensive income and its relation to firm value and transitory earnings. Ph.D., Louisiana State University and Agricultural \& Mechanical College, United States -- Louisiana.

Demirakos, E. G., N. Strong, and M. Walker. 2004. What valuation models do analysts use. Accounting Horizons 18 (4):221-240.

Dhaliwal, D., O. Z. Li, A. Tsang, and Y. G. Yang. 2011. Voluntary Nonfinancial Disclosure and the Cost of Equity Capital: The Initiation of Corporate Social Responsibility Reporting. Accounting Review 86 (1):59-100.

Dhaliwal, D., K. R. Subramanyam, and R. Trezevant. 1999. Is comprehensive income superior to net income as a measure of firm performance? Journal of Accounting \& Economics 26 (1-3):43-67.

Duke, J. C., and H. G. Hunt. 1990. An empirical examination of debt covenant restrictions and accounting-related debt proxies. Journal of Accounting and Economics 12 (1):45-63.

Eames, M., S. M. Glover, and J. Kennedy. 2002. The association between trading recommendations and broker-analysts' earnings forecasts. Journal of Accounting Research 40 (1):85.

Easterwood, J. C., and S. R. Nutt. 1999. Inefficiency in analysts' earnings forecasts: Systematic misreaction or systematic optimism? The Journal of Finance 54 (5):1777.

Fama, E. F. 1970. Efficient Capital Markets: A Review of Theory and Empirical Work. The Journal of Finance 25 (2):383-417. 
—_. 1991. Efficient Capital Markets: II. The Journal of Finance 46 (5):1575-1617.

Fama, E. F., and K. R. French. 1992. The cross-section of expected stock returns. The Journal of Finance 47 (2):427-465.

Fan, D. K. K., R. W. So, and J. J. Yeh. 2006. Analyst Earnings Forecasts for Publicly Traded Insurance Companies. Review of Quantitative Finance and Accounting 26 (2):105.

Feltham, G. A., and J. A. Ohlson. 1995. Valuation and clean surplus accounting for operating and financial activities. Contemporary Accounting Research 11 (2):689.

-1996. Uncertainty resolution and the theory of depreciation measurement. Journal of Accounting Research 34 (2):209.

Financial Accounting Policy Committee. 1992. Financial Reporting in the 1990s and beyond: An Executive Summary. Financial Analysts Journal 48 (6):21-23.

Finger, C. A. 1994. The ability of earnings to predict future earnings and cash flow. Journal of Accounting Research:210-223.

Foster, N., and N. L. Hall. 1996. Reporting comprehensive income. The CPA Journal 66 (10):16.

Freeman, R. N., and S. Y. Tse. 1992. A nonlinear model of security price responses to unexpected earnings. Journal of Accounting Research:185-209.

Fried, D., and D. Givoly. 1982. Financial analysts' forecasts of earnings: A better surrogate for market expectations. Journal of Accounting and Economics 4 (2):85-107.

Gaynor, L. M., L. McDaniel, and T. L. Yohn. 2011. Fair value accounting for liabilities: The role of disclosures in unraveling the counterintuitive income statement effect from credit risk changes. Accounting, Organizations and Society 36 (3):125-134.

Godwin, N. H., and C. W. Alderman. 1999. Avoiding the implementation costs of SFAS No. 130. The CPA Journal 69 (6):52.

Goncharov, I., and A. Hodgson. 2008. Comprehensive Income In Europe: Valuation, Prediction And Conservative Issues. Annales Universitatis Apulensis Series Oeconomica 1 (10).

—. 2011. Measuring and Reporting Income in Europe. Journal of International Accounting Research 10 (1):27. 
Graham, R. C., C. E. Lefanowicz, and K. R. Petroni. 2003. The Value Relevance of Equity Method Fair Value Disclosures. Journal of Business Finance \& Accounting 30 (78):1065-1088.

Gray, T. 2005. Canadian Response to the U.S. Sarbanes-Oxley Act of 2002: New Directions for Corporate Governance, edited by Economics Division: Parliamentary Information and Research Service.

Gu, Z., and T. Chen. 2004. Analysts' treatment of nonrecurring items in street earnings. Journal of Accounting and Economics 38:129-170.

Gu, Z., and J. S. Wu. 2003. Earnings skewness and analyst forecast bias. Journal of Accounting \& Economics 35 (1):5.

Hair, J., W. Black, B. Balin, and R. Anderson. 2010. Multivariate data analysis. 7th ed. Upper Saddle River, NJ 07458: Prentice Hall.

Haka, S., L. Friedman, and V. Jones. 1986. Functional Fixation and Interference Theory: A Theoretical and Empirical Investigation. The Accounting Review 61 (3):455-474.

Han, B. H., and D. Manry. 2000. The implications of dispersion in analysts' earnings forecasts for future ROE and future returns. Journal of Business Finance \& Accounting 27 (1/2):99.

Han, B. H., D. Manry, and W. Shaw. 2001. Improving the Precision of Analysts' Earnings Forecasts by Adjusting for Predictable Bias. Review of Quantitative Finance and Accounting 17 (1):81.

Harris, T. S., and J. A. Ohlson. 1990. Accounting Disclosures and the Market's Valuation of Oil and Gas Properties: Evaluation of Market Efficiency and Functional Fixation. The Accounting Review 65 (4):764-780.

Hayn, C. 1995. The information content of losses. Journal of Accounting and Economics 20 (2):125-153.

Hendry, S., and M. R. King. 2004. The Efficiency of Canadian Capital Markets: Some Bank of Canada Research. Bank of Canada Review Summer.

Hillegeist, S. A., and F. Penalva. 1999. The valuation implications of comprehensive income: Working Paper, Northwestern University and University of Navarre. 
Hirst, D. E., and P. E. Hopkins. 1998. Comprehensive Income Reporting and Analysts' Valuation Judgments. Journal of Accounting Research 36:47-75.

Hirst, D. E., P. E. Hopkins, and J. M. Wahlen. 2004. Fair values, income measurement, and bank analysts' risk and valuation judgments. Accounting Review:453-472.

Hirst, D. E., L. Koonce, and P. J. Simko. 1995. Investor Reactions to Financial Analysts' Research Reports. Journal of Accounting Research 33 (2):335-351.

Hodder, L., P. E. Hopkins, and D. A. Wood. 2008. The Effects of Financial Statement and Informational Complexity on Analysts' Cash Flow Forecasts. Accounting Review 83 (4):915-956.

Holthausen, R. W., and R. L. Watts. 2001. The relevance of the value-relevance literature for financial accounting standard setting. Journal of Accounting and Economics 31 (1-3):375.

Hope, O.-K. 2003. Accounting policy disclosures and analysts' forecasts*. Contemporary Accounting Research 20 (2):295.

Hsu, D., and C. Chiao. 2011. Relative accuracy of analysts' earnings forecasts over time: a Markov chain analysis. Review of Quantitative Finance and Accounting 37 (4):477.

Hughes, J., J. Liu, and W. Su. 2008. On the relation between predictable market returns and predictable analyst forecast errors. Review of Accounting Studies 13 (2-3):266.

Hunton, J. E., R. Libby, and C. Mazza. 2006. Financial reporting transparency and earnings management. The Accounting Review 81 (1):135-157.

Ijiri, Y., and R. K. Jaedicke. 1966. Reliability and Objectivity of Accounting Measurements. The Accounting Review 41 (3):474-483.

Imhoff, E., R. C. Lipe, and D. W. Wright. 1995. Is footnote disclosure an adequate alternative to financial statement recognition. Journal of Financial Statement Analysis 1 (1):70-81.

Industry Canada. 2013. SME Benchmarking 2010 [cited 20 February 2013 2013]. Available from http://www.ic.gc.ca/eic/site/cis-sic.nsf/eng/h_00032.html.

Johnson, L. T., C. L. Reither, and R. J. Swieringa. 1995. Toward reporting comprehensive income. Accounting Horizons 9 (4):128. 
Johnson, L. T., and R. J. Swieringa. 1996. Derivatives, hedging and comprehensive income. Accounting Horizons 10 (4):109.

Johnson, P., T. Lopez, and J. Sanchez. 2011. Special Items: A Descriptive Analysis. Accounting Horizons 25 (3):511.

Jones, D. A., and K. J. Smith. 2011. Comparing the Value Relevance, Predictive Value, and Persistence of Other Comprehensive Income and Special Items. Accounting Review 86 (6):2047-2073.

Kanagaretnam, K., R. Mathieu, and M. Shehata. 2009. Usefulness of comprehensive income reporting in Canada. Journal of Accounting and Public Policy 28 (4):349-365.

Kantsyrev, D. 2007. Essays on the properties of financial analysts' forecasts. 3262741, University of Southern California, United States -- California.

Karamanou, I. 2000. Is analyst optimism intentional? Additional evidence on the existence of reporting, selection and cognitive bias in analyst earnings forecasts. 9998371, The Pennsylvania State University, United States -- Pennsylvania.

Keating, M. 1999. An analysis of the value of reporting comprehensive income. Journal of Accounting Education 17 (2-3):333-339.

Keung, E. 2010. Do Supplementary Sales Forecasts Increase the Credibility of Financial Analysts' Earnings Forecasts? Accounting Review 85 (6):2047-2074.

Kieso, D. E., J. J. Weygandt, T. D. Warfield, N. M. Young, and I. M. Wiecek. 2007. Intermediate Accounting. 8th Canadian Edition ed. Mississauga: John Wiley \& Sons Canada, Ltd.

Kim, M., and W. Kross. 2005. The ability of earnings to predict future operating cash flows has been increasing—not decreasing. Journal of Accounting Research 43 (5):753-780.

Knutson, P. H., and AIMR. 1993. Financial Reporting in the 1990s and Beyond: A Position Paper: Association for Investment Management and Research.

Koonce, L., K. K. Nelson, and C. M. Shakespeare. 2011. Judging the Relevance of Fair Value for Financial Instruments. Accounting Review 86 (6):2075-2098. 
Kothari, S. 2001. Capital markets research in accounting. Journal of Accounting and Economics 31 (1-3):105-231.

Kothari, S., J. Shanken, and R. G. Sloan. 1995. Another look at the cross-section of expected stock returns. The Journal of Finance 50 (1):185-224.

Kothari, S. P., and J. L. Zimmerman. 1995. Price and return models. Journal of Accounting and Economics 20 (2):155-192.

Kubota, K., K. Suda, and H. Takehara. 2006. Reporting of the Current Earnings plus Other Comprehensive Income: Information Content Test of the Japanese Firms and Industries: Musahi University and Waseda University, Japan.

Lafrance, A. 2012. Firm Dynamics: Variation in Profitability Across Canadian Firms of Different Sizes, 2000 to 2009. In The Canadian Economy in Transition Series.

Lang, M. H., and R. J. Lundholm. 1996. Corporate disclosure policy and analyst behavior. Accounting Review:467-492.

Lee, Y.-J., K. R. Petroni, and M. Shen. 2006. Cherry Picking, Disclosure Quality, and Comprehensive Income Reporting Choices: The Case of Property-Liability Insurers. Contemporary Accounting Research 23 (3):655.

Lehavy, R., F. Li, and K. Merkley. 2011. The Effect of Annual Report Readabifity on Analyst Followmig and the Properties of Their Earmings Forecasts. Accounting Review 86 (3):1087-1115.

Lev, B., and J. A. Ohlson. 1982. Market-Based Empirical Research in Accounting: A Review, Interpretation, and Extension. Journal of Accounting Research 20:249-322.

Libby, R., J. Hunton, H. Tan, and N. Seybert. 2008. Relationship Incentives and the Optimistic/Pessimistic Pattern in Analysts' Forecasts. Journal of Accounting Research 46 (1):173.

Linsmeier, T. J., J. Gribble, R. G. Jennings, and M. H. Lang. 1997a. An issues paper on comprehensive income. Accounting Horizons 11 (2):120. 1997b. Response to FASB exposure draft, "proposed statement of financial accounting standards--reporting comprehensive income". Accounting Horizons 11 (2):117. 
Littleton, A. 1940. The integration of income and surplus statements. Journal of Accountancy (January):30-40.

Lo, K., and T. Lys. 2000. Bridging the gap between value relevance and information content. Unpublished working paper, University of British Columbia and Northwestern University.

Louis, H. 2001. The relevance of the foreign translation adjustment and the effects of dirty surplus items on net income. Ph.D., The Ohio State University, United States -- Ohio.

. 2003. The value relevance of the foreign translation adjustment. The Accounting Review 78 (4):1027.

Maines, L. A., and L. S. McDaniel. 2000. Effects of comprehensive-income characteristics on nonprofessional investors' judgments: The role of financial-statement presentation format. The Accounting Review 75 (2):179.

Malkiel, B. G. 2005. Reflections on the efficient market hypothesis: 30 years later. Financial Review 40 (1):1-9.

Malkiel, B. G., and E. F. Fama. 1970. Efficient Capital Markets: A Review Of Theory And Empirical Work*. The Journal of Finance 25 (2):383-417.

Mikhail, M. B., B. R. Walther, and R. H. Willis. 2007. When security analysts talk, who listens? The Accounting Review 82 (5):1227-1253.

Miller, T. 2008. Differential Reporting 2002 [cited March 19 2008]. Available from http://www.wolrigemahon.com/articles.html?ed=200206\&article=1.

Nikolaev, V. V. 2010. Debt covenants and accounting conservatism. Journal of Accounting Research 48 (1):51-89.

Norton, C. L., and G. A. Porter. 1982. The Comprehensive Income Approach and FASB Statement No. 52: Are They Compatible? Journal of Accountancy 154 (6):94.

O'Hanlon, J. F., and P. F. Pope. 1999. The Value-Relevance Of UK Dirty Surplus Accounting Flows. The British Accounting Review 31 (4):459-482. 
Ofer, A. R., and D. R. Siegel. 1987. Corporate financial policy, information, and market expectations: An empirical investigation of dividends. The Journal of Finance 42 (4):889-911.

Ohlson, J. A. 1995. Earnings, book values, and dividends in equity valuation. Contemporary Accounting Research 11 (2):661.

—. 1999. On Transitory Earnings. Review of Accounting Studies 4 (3-4):145-162.

Ontario Securities Commission. Continuous Disclosure [cited December 21, 2012. Available from http://www.osc.gov.on.ca/en/Companies_continuous-disclosure_index.htm.

Orpurt, S. F., and Y. Zang. 2009. Do direct cash flow disclosures help predict future operating cash flows and earnings? The Accounting Review 84 (3):893-935.

Ou, J. A., and J. F. Sepe. 2002. Analysts earnings forecasts and the roles of earnings and book value in equity valuation. Journal of Business Finance \& Accounting 29 (3/4):287.

Pandit, G. M., and J. J. Phillips. 2004. Comprehensive Income: Reporting Preferences of Public Companies. The CPA Journal 74 (11):40.

Pandit, G. M., A. Rubenfield, and J. J. Phillips. 2006. Current NASDAQ Corporation Methods of Reporting Comprehensive Income. Mid - American Journal of Business 21 (1):13.

Payne, J. 2008. The Influence of Audit Firm Specialization on Analysts' Forecast Errors. Auditing 27 (2):109.

Plumlee, M. A. 2003. The effect of information complexity on analysts' use of that information. Accounting Review:275-296.

Posner, E. A., and A. Vermeule. 2009. Crisis Governance in the Administrative State: 9/11 and the Financial Meltdown of 2008. U. Chi. L. Rev. 76:1613.

Preinreich, G. A. D. 1936. The Fair Value and Yield of Common Stock. The Accounting Review 11 (2):130-140.

Previts, G. J., R. J. Brioker, T. R. Robinson, and S. J. Young. 1994. A Content Analysis of SellSide Financial Analyst Company Reports. Accounting Horizons 8 (2):55-70. 
PriceWaterhouseCoopers. 2005. The New CICA Financial Instrument Standards: An Overview: PriceWaterhouseCoopers LLP, Canada.

Qiang, C. 2005. The Role of Analysts' Forecasts in Accounting-Based Valuation: A Critical Evaluation. Review of Accounting Studies 10 (1):5.

Ramnath, S., S. Rock, and P. Shane. 2008. The financial analyst forecasting literature: A taxonomy with suggestions for further research. International Journal of Forecasting 24 (1):34-75.

Randall, W. L., and T. M. David. 1998. How companies report income. Journal of Accountancy 185 (5):45.

Rao, A., and R. J. Walsh. 1999. Impact of "reporting comprehensive income" on large multinational firms. Southern Business Review 25 (1):22.

Reinhart, C. M., and K. S. Rogoff. 2008. This time is different: A panoramic view of eight centuries of financial crises: National Bureau of Economic Research.

Robinson, L. E. 1991. The Time Has Come to Report Comprehensive Income. Accounting Horizons 5 (2):107.

Russo, J. E. 1977. The Value of Unit Price Information. Journal of Marketing Research 14 (2):193-201.

Sanbonmatsu, D. M., F. R. Kardes, S. S. Posavac, and D. C. Houghton. 1997. Contextual Influences on Judgment Based on Limited Information. Organizational Behavior and Human Decision Processes 69 (3):251-264.

Schroeder, R. G., and M. Clark. 1995. Chapter 1: The Development of Accounting Theory. In Accounting Theory: Text and Readings. Toronto: John Wiley \& Sons, Inc.

Shanken, J. 1992. On the estimation of beta-pricing models. Review of Financial Studies 5 (1):155.

Shiller, R. J. 2003. From efficient markets theory to behavioral finance. The Journal of Economic Perspectives 17 (1):83-104.

Shleifer, A. 2000. Inefficient Markets: An Introduction to Behavioral Finance: An Introduction to Behavioral Finance: OUP Oxford. 
Skinner, D. J. 1999. How well does net income measure firm performance? A discussion of two studies. Journal of Accounting \& Economics 26 (1-3):105.

Sloan, R. G. 1996. Do stock prices fully reflect information in accruals and cash flows about future earnings? Accounting Review:289-315.

Smith, P. A., and C. L. Reither. 1996. Comprehensive income and the effect of reporting it. Financial Analysts Journal 52 (6):14.

Sougiannis, T., and T. Yaekura. 2001. The accuracy and bias of equity values inferred from analysts' earnings forecasts. Journal of Accounting, Auditing \& Finance 16 (4):331.

Srinidhi, B., S. Leung, and B. Jaggi. 2009. Differential effects of regulation FD on short- and long-term analyst forecasts. Journal of Accounting and Public Policy 28 (5):401.

Stiglitz, J. E. 2009. The Financial Crisis of 2007-2008 and its Macroeconomic Consequences.

Subrahmanyam, A. 2007. Behavioural finance: A review and synthesis. European Financial Management 14 (1):12-29.

Tan, H., S. Wang, and M. Welker. 2011. Analyst Following and Forecast Accuracy After Mandated IFRS Adoptions. Journal of Accounting Research 49 (5):1307.

Van Cauwenberge, P. 2007. Essays on Comprehensive Income.

Venkatachalam, M. 1996. Value-relevance of banks' derivatives disclosures. Journal of Accounting and Economics 22 (1-3):327-355.

Watts, R. L., and J. L. Zimmerman. 1978. Towards a positive theory of the determination of accounting standards. Accounting Review:112-134.

Zeff, S. A. 1997. The Rise of "Economic Consequences". In Readings \& Notes on Financial Accounting: Issues \& Controversies, edited by S. A. Zeff and B. G. Dharan. Boston: Irwin McGraw-Hill.

. 2002. "Political" Lobbying on Proposed Standards: A Challenge to the IASB. Accounting Horizons 16 (1):43-55. 